UNIVERSIDADE DE SÃO PAULO

FACULDADE DE ECONOMIA, ADMINISTRAÇÃO E CONTABILIDADE DE RIBEIRÃO PRETO

DEPARTAMENTO DE CONTABILIDADE

CIBELLE MARIA DO AMORIM FERREIRA

O equilíbrio econômico-financeiro das distribuidoras de energia elétrica brasileiras nas demonstrações contábeis

Orientador: Prof. Dr. Vinícius Aversari Martins

RIBEIRÃO PRETO

2009 
Profa. Dra. Suely Vilela Sampaio Reitora da Universidade de São Paulo

Prof. Dr. Rudinei Toneto Júnior

Diretor da Faculdade de Economia, Administração e Contabilidade de Ribeirão Preto

Profa. Dra. Adriana Maria Procópio de Araújo

Chefe do Departamento de Contabilidade 
CIBELLE MARIA DO AMORIM FERREIRA

\section{O equilíbrio econômico-financeiro das distribuidoras de energia elétrica brasileiras nas demonstrações contábeis}

Dissertação apresentada ao Programa de PósGraduação em Controladoria e Contabilidade da Faculdade de Economia, Administração e Contabilidade de Ribeirão Preto da Universidade de São Paulo como requisito para obtenção do título de Mestre em Contabilidade.

Orientador: Prof. Dr. Vinícius Aversari Martins 
Ferreira, Cibelle Maria do Amorim

O equilíbrio econômico-financeiro das distribuidoras de energia elétrica brasileiras nas demonstrações contábeis. Ribeirão Preto, 2009.

176 p. : il. ; $30 \mathrm{~cm}$

Dissertação de Mestrado, apresentada à Faculdade de Economia, Administração e Contabilidade de Ribeirão Preto da Universidade de São Paulo.

Orientador: Martins, Vinícius Aversari.

1. Contabilidade regulatória. 2. Normas internacionais de contabilidade. 3. Distribuidoras de energia elétrica. 4. Equilíbrio econômico-financeiro. 


\section{FOLHA DE APROVAÇÃO}

Cibelle Maria do Amorim Ferreira

O equilíbrio econômico-financeiro das distribuidoras de energia elétrica brasileiras nas demonstrações contábeis.

Dissertação apresentada ao Departamento de Contabilidade da Faculdade de Economia, Administração e Contabilidade de Ribeirão Preto da Universidade de São Paulo, como parte dos requisitos para obtenção do título de Mestre em Contabilidade.

Área de concentração: Controladoria e Contabilidade

Aprovada em:

Banca Examinadora

Prof. Dr.

Instituição:

Assinatura:

Prof. Dr.

Instituição:

Assinatura:

Prof. Dr.

Instituição:

Assinatura: 


\section{AGRADECIMENTOS}

Foram muitas as pessoas que me incentivaram e acompanharam na elaboração deste trabalho. A esse incentivo e apoio serei eternamente grata. Gostaria, todavia, de registrar alguns agradecimentos em especial:

Ao Prof. Dr. Vinícius Aversari Martins, pela paciência, contribuição e orientação.

Ao Prof. Dr. Francisco Anuatti Neto, pelas contribuições e longas discussões sobre esse assunto fascinante, porém complexo. Na certeza de que aprendi muito mais do que consegui incluir nessas páginas.

Aos meus amigos de mestrado da Turma III, principalmente à minha amiga Tatiana Albanez, pela sua amizade e por ter me ajudado a enxergar a luz no fim do túnel.

Aos meus filhos, Ruan e Micaela, pela compreensão, pelas horas de lazer roubadas, e a minha mãe, Jaci, pelo exemplo de perseverança.

Ao meu marido Aldair, pelo encorajamento, amor, carinho e dedicação ao longo desta empreitada. 


\section{RESUMO}

FERREIRA, Cibelle Maria do Amorim. O equilíbrio econômico-financeiro das distribuidoras de energia elétrica brasileiras nas demonstrações contábeis. 2009. 176 f. Dissertação (Mestrado) - Faculdade de Economia, Administração e Contabilidade de Ribeirão Preto, Universidade de São Paulo, Ribeirão Preto, 2009.

Este trabalho analisa a potencialidade da contabilidade na identificação do equilíbrio econômico-financeiro dos contratos de concessão de distribuição do setor elétrico brasileiro. São apresentadas as abordagens da contabilidade regulatória do setor em questão, o novo ambiente contábil societário estabelecido pela lei 11.638/2007 e a Medida Provisória 449/2008, que altera a legislação societária vigente, a fim de fornecer elementos teóricos para discussão do papel da contabilidade na regulação econômica. Especial ênfase é dada aos subsídios contábeis na determinação e manutenção do equilíbrio econômico-financeiro dos contratos de concessão do serviço de distribuição de energia elétrica no Brasil, para identificar como estes podem conter restrições à adoção de um novo modelo de contabilidade. A análise procura investigar a contabilidade regulatória como instrumento de regulação econômica do setor de distribuição de energia elétrica para entender sua contribuição na identificação do equilíbrio econômico-financeiro estabelecido pelo marco regulatório do setor elétrico nacional, haja vista a mudança estabelecida pela Lei 11.638/2007. Para tanto, a metodologia utilizada é uma pesquisa analítica e comparativa através da simulação de um contrato de concessão de acordo com o modelo contábil atual e o novo modelo com a aplicação das interpretações internacionais de contabilidade. Conclui-se que o modelo elaborado de acordo com as normas internacionais de contabilidade proporciona melhor identificação do equilíbrio econômico e financeiro estabelecido nos contratos de concessão.

Palavras-Chave: Contabilidade regulatória. Normas internacionais de contabilidade. Distribuidoras de energia elétrica. Equilíbrio econômico-financeiro. 


\begin{abstract}
FERREIRA, Cibelle Maria do Amorim. The economic and financial equilibrium of Brazilian electricity distribution companies in the accounting reports. 2009. $176 \mathrm{p}$. Dissertation (Master's Degree) - Faculdade de Economia, Administração e Contabilidade de Ribeirão Preto, Universidade de São Paulo, Ribeirão Preto, 2009.

This work analyzes the accounting potentiality in the identification of the economic and financial equilibrium of the distribution concession contracts of Brazilian electrical sector.

The regulatory accounting approaches of the mentioned sector are presented, the new business accounting environment established by law 11.638/2007 and the law 449/2008, which alters the effective partnership law, in order to provide theoretical elements to discuss the role of accounting in economic regulation. Especial emphasis is given to account subsidies when determining and maintaining the economic and financial equilibrium of concession contracts for electricity distribution service in Brazil, to identify how they may be restrictive to the adoption of a new accounting standard. The analysis tries to investigate the regulatory accounting as an economic regulation tool of the electricity distribution sector to understand the identification of the economic and financial equilibrium established by the regulatory mark of national electricity sector, have seen the change of the law 11.638/2007. Therefore, the methodology used is analytical and comparative research through simulation of a concession contract according to the effective accounting model and the new model applying accounting international standards. It was concluded that the model elaborated according to international accounting standards provides better identification of economic and financial equilibrium established in concession contracts.
\end{abstract}

Key-words: Regulatory accounting. International accounting standards. Electricity distribution companies. Economic and financial equilibrium. 


\section{LISTA DE ABREVIATURAS E SIGLAS}

ABRACE: Associação Brasileira de Grandes Consumidores Industriais de Energia e de Consumidores Livres.

ABRACONEE: Associação Brasileira dos Contadores do Setor de Energia Elétrica.

ABRADEE: Associação Brasileira de Distribuidores de Energia Elétrica.

AIS: Ativo Imobilizado em Serviço.

ANEEL: Agência Nacional de Energia Elétrica.

BRR: Base de Remuneração Regulatória (ou Base de Ativos Regulatória).

CAPEX: Capital Expenditures - gastos de capital.

CPC: Comitê de Pronunciamentos Contábeis.

EEF: Equilíbrio econômico-financeiro, estabelecido no contrato de concessão.

ER: Empresa de Referência.

$\mathrm{IR}_{\mathrm{reg}}$ : Indicador de Rentabilidade Regulatório.

MCSPEE: Manual de Contabilidade do Serviço Público de Energia Elétrica.

OPEX: Operating Expenditures - gastos de operação.

Parcela A: Parcela relativa aos custos não gerenciáveis incluídos nas tarifas.

Parcela B: Parcela relativa aos custos gerenciáveis incluídos nas tarifas.

QRR: Quota de Reintegração Regulatória.

RE: Receita de Equilíbrio.

RTP: Revisão Tarifária Periódica.

ROI: Retorno sobre o Investimento.

SFF: Superintendência de Fiscalização Econômico-Financeira.

SRE: Superintendência de Regulação Econômica.

TMD: Taxa média de depreciação contábil. 


\section{LISTA DE QUADROS}

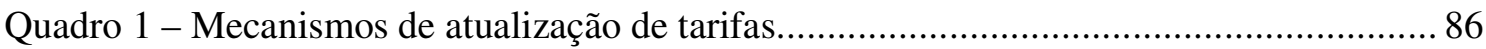

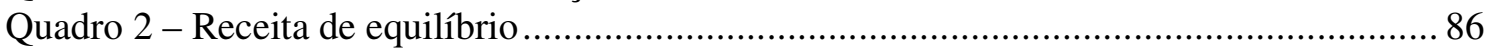

Quadro 3 - Mecanismos utilizados pelo regulador brasileiro ......................................... 87

Quadro 4 - Remuneração total de capital ................................................................ 91

Quadro 5 - Total de empresas de distribuição com aprovação da base de ativos ................... 95

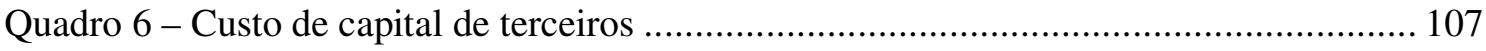

Quadro 7 - Demonstrativos financeiros - modelo societário atual.................................... 113

Quadro 8 - Demonstrativos financeiros - modelo societário atual................................... 120

Quadro 9 - Proporção da BRR em relação ao ativo imobilizado líquido........................... 123

Quadro 10 - Taxa média de depreciação contábil ...................................................... 126

Quadro 11 - Quota de reintegração regulatória - QRR ................................................... 127

Quadro 12 - Receita de equilíbrio - primeiro ciclo tarifário............................................... 130

Quadro 13 - Formação da base de remuneração regulatória do $2^{\circ}$ ciclo revisório ................ 131

Quadro 14 - Receita de equilíbrio - segundo ciclo de revisão tarifária................................ 132

Quadro 15 - Extrato do balanço da concessão - 1998 e 2003-2007.................................... 132

Quadro 16 - Demonstrativos financeiros - modelo societário atual................................... 134

Quadro 17 - Extrato do balanço da concessão - ativo imobilizado................................... 135

Quadro 18 - Ativação e baixa do investimento realizado no ano de 2004 .......................... 136

Quadro 19 - Ativação do investimento realizado no ano de 2009 ...................................... 137

Quadro 20 - Fluxo de caixa do período 2003-2007 ..................................................... 140

Quadro 21 - Fluxo de caixa da concessão 2008-2012 ....................................................... 140

Quadro 22 - Fluxo de caixa da concessão 2003-2008 - sem investimentos adicionais ........ 141

Quadro 23 - Formulação analítica do ROI ........................................................... 142

Quadro 24 - Comparação ativo imobilizado líquido x base de ativos regulatória................ 144

Quadro 25 - Demonstrativos financeiros de acordo com a interpretação IFRIC $12 \ldots \ldots . . . . . .149$

Quadro 26 - Extrato do balanço da concessão - modelo IFRIC12 - ativo intangível ........... 151

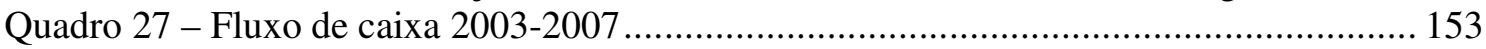

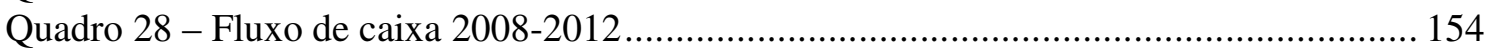

Quadro 29 - Fluxo de caixa da concessão 2003-2008 - sem investimentos adicionais ........ 155

Quadro 30 - Formulação analítica do ROI .............................................................. 155

Quadro 31 - Extrato do balanço da concessão - modelo IFRIC12 - ativo intangível ............ 160 


\section{LISTA DE TABELAS}

Tabela 1 - Quantitativo de aprovação de reestruturação societária ...................................69

Tabela 2 - Custo médio ponderado de capital............................................................... 108 Tabela 3 - Tabela comparativa dos indicadores apurados pelo modelo societário atual e pelo

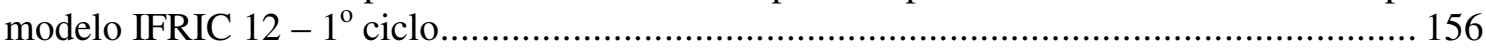
Tabela 4 - Tabela comparativa dos indicadores apurados pelo modelo societário atual e pelo

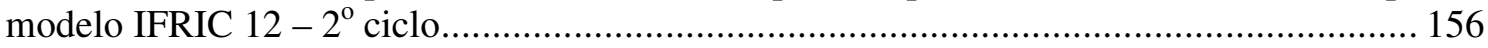

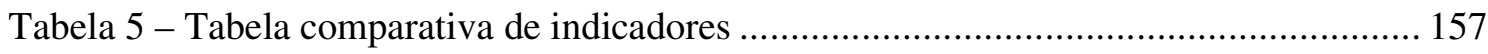

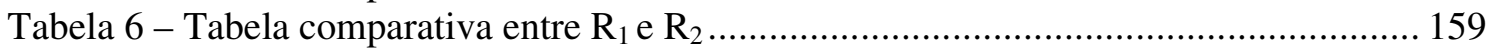

Tabela 7 - Principais diferenças encontradas - modelo societário atual versus modelo IFRIC

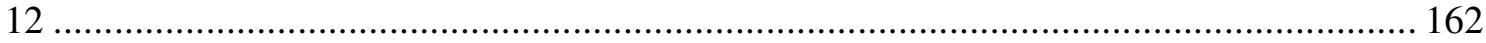




\section{LISTA DE FIGURAS}

Figura 1 - Exemplo de uma conta contábil do plano de contas .......................................... 34

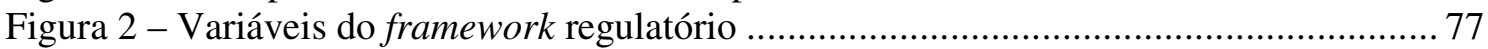




\section{SUMÁRIO}

1. INTRODUÇÃ

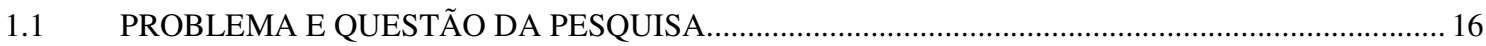

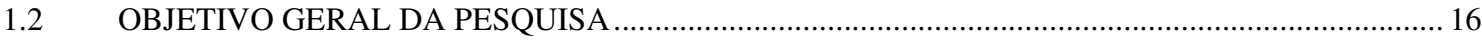

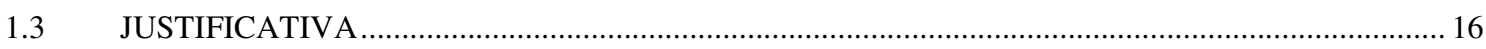

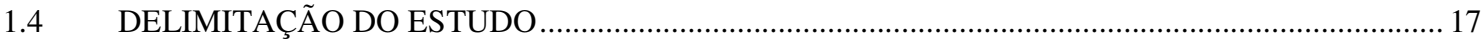

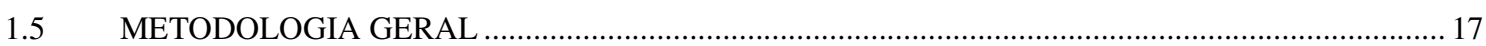

1.6 DISTRIBUIÇÃO TEMÁTICA E ORGANIZAÇÃO DO TRABALHO ……………………………..... 19

2. CONTABILIDADE REGULATÓRIA E SOCIETÁRIA.................................................20

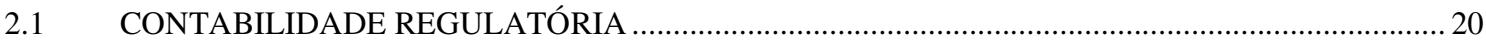

2.1.1 Contabilidade regulatória do setor elétrico brasileiro.............................................................. 25

2.1.2 O Manual de Contabilidade do Serviço Público de Energia Elétrica - MCSPEE........................2 27

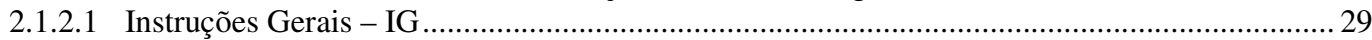

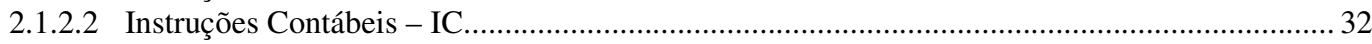

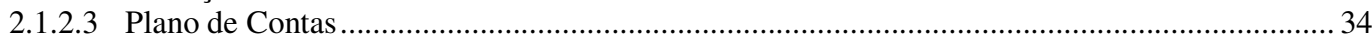

2.1.3 Aspectos distintivos entre a Contabilidade Regulatória e a Contabilidade Societária ................36 36

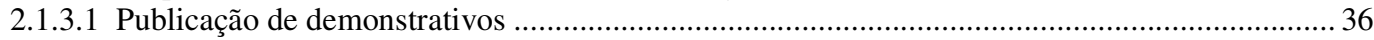

2.1.3.2 Reestruturação societária visando à incorporação de ágio ......................................................... 38

2.1.3.3 Segregação contábil das atividades de geração, transmissão e distribuição e as sociedades de

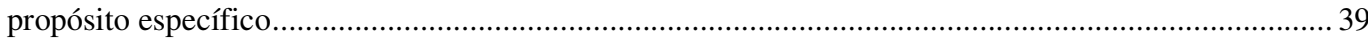

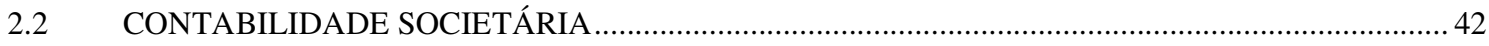

2.2.1 Um novo modelo para a contabilidade societária........................................................................4 43

2.2.2 Normas internacionais para concessões ............................................................................. 47

2.2.2.1 IFRIC 12 - Service Concession Arrangements ....................................................................... 48

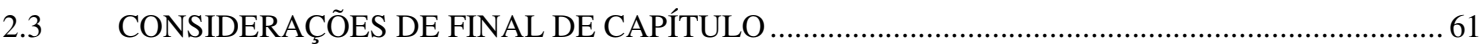

3 A CONTABILIDADE REGULATÓRIA NA REGULAÇÃO ECONÔMICA .... 63

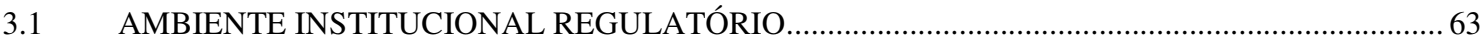

3.2 OS SUBSÍDIOS CONTÁBEIS NA FISCALIZAÇÃO ECONÔMICA E FINANCEIRA ……………... 66

3.2.1 Casos de atuação da fiscalização econômico-financeira ......................................................... 69

3.2.1.1 Caso da Companhia Energética de Roraima - CER ......................................................... 70

3.2.1.2 Caso da Companhia Energética do Maranhão - CEMAR ..................................................... 70

3.2.1.3 Caso da Empresa Energética do Mato Grosso do Sul - ENERSUL ....................................... 71

3.2.1.4 Caso da Centrais Elétricas de Santa Catarina - CELESC ........................................................ 71

3.3 OS SUBSÍDIOS CONTÁBEIS NA REGULAÇÃO TARIFÁRIA........................................................ 72

3.3.1 Aspectos da regulação econômica.................................................................................. 73

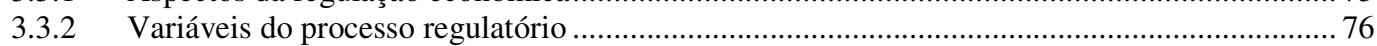

3.3.3 Interpretações sobre o equilíbrio economico-financeiro dos contratos de concessão ............... 78

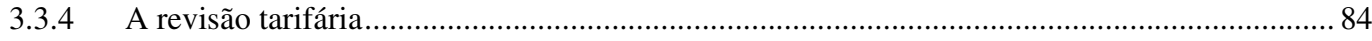

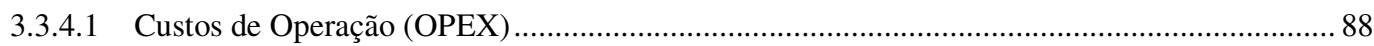

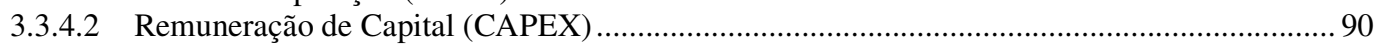


3.3.4.2.1 Base de Remuneração Regulatória .................................................................................... 92

3.3.4.2.2Taxa de Retorno - Custo Médio Ponderado de Capital .......................................................... 100

3.3.4.2.3Quota de Reintegração Regulatória.................................................................................. 112

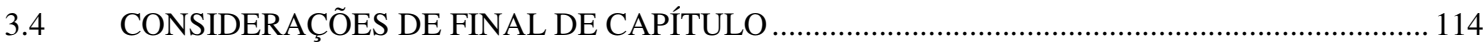

4. ANÁLISE COMPARATIVA: MODELO SOCIETÁRIO ATUAL VERSUS MODELO DE ACORDO COM A IFRIC 12 ............................................................. 116

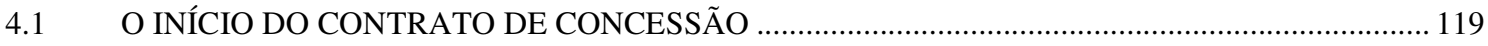

4.2 AS REVISÕES TARIFÁRIAS PERIÓDICAS ...................................................................... 121

4.2.1 Análise dos componentes da Receita de Equilíbrio............................................................ 122

4.2.1.1 Base de Remuneração Regulatória ............................................................................... 123

4.2.1.2 Quota de Reintegração Regulatória............................................................................ 124

4.2.1.3 Formação da Receita de Equilíbrio................................................................................... 129

4.3 SIMULAÇÃO DAS DEMONSTRAÇÕES FINANCEIRAS DE UM CONTRATO DE CONCESSÃO

DE ACORDO COM O MODELO SOCIETÁRIO ATUAL .................................................................... 133

4.3.1 Evidenciação do Ativo, sua evolução e investimentos realizados ............................................ 135

4.3.2 Visualização do Equilíbrio Econômico-Financeiro - EEF após a revisão tarifária................. 139

4.4 SIMULAÇÃO DAS DEMONSTRAÇÕES FINANCEIRAS DE UM CONTRATO DE CONCESSÃO

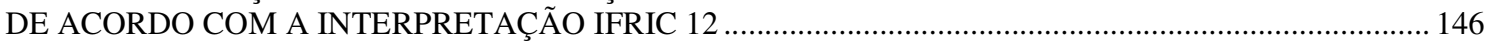

4.4.1 Evidenciação do Ativo, sua evolução e investimentos realizados ............................................ 150

4.4.2 Visualização do Equilíbrio Econômico-Financeiro - EEF após a revisão tarifária................. 152

4.5 PRINCIPAIS DIFERENÇAS ENCONTRADAS ............................................................. 161

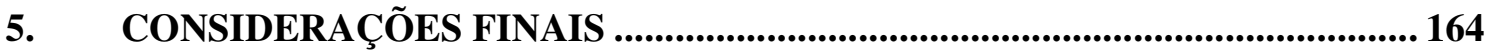

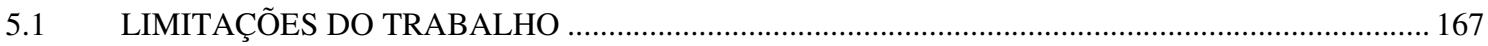

REFERÊNCIAS BIBLIOGRÁFICAS ....................................................................... 168 


\section{INTRODUÇÃO}

A contabilidade societária passou por mudanças significativas com a edição da Lei 11.638, de 28/12/2007, que altera e revoga dispositivos da Lei $n^{0}$ 6.404, de 15/12/1976, sendo um dos objetivos de tais mudanças a elaboração dos demonstrativos em consonância com os padrões internacionais de contabilidade adotados nos principais mercados de valores mobiliários, conforme art. $177, \S 5^{\mathrm{o}}$ :

Art. 177. A escrituração da companhia será mantida em registros permanentes, com obediência aos preceitos da legislação comercial e desta Lei e aos princípios de contabilidade geralmente aceitos, devendo observar métodos ou critérios contábeis uniformes no tempo e registrar as mutações patrimoniais segundo o regime de competência.

[...]

$\S 5^{\circ}$ As normas expedidas pela Comissão de Valores Mobiliários a que se refere o $\S$ $3^{\circ}$ deste artigo deverão ser elaboradas em consonância com os padrões internacionais de contabilidade adotados nos principais mercados de valores mobiliários.

Por padrões internacionais entende-se como sendo a normatização emitida pelo International Accounting Standards Board - IASB, que tem como bandeira, segundo Martins, Martins e Martins (2007, p. 18):

... sua bandeira mor é a essência sobre a forma, a ponto de, em seu IAS 1, definir que, na hora da aplicação de suas normas, se alguma delas, em situação que se acredita seja rara, produzir qualquer deformação em qualquer informação contábil, ela não poderá ser usada e terá que ser substituída por outra que retrate melhor o que precisa ser contabilizado. Caso contrário, não poderá a empresa dizer que está seguindo as normas internacionais! Ou seja, a substância econômica é mais relevante do que as regras propriamente ditas.

Procura trabalhar com base na filosofia do principles oriented, ou seja, suas normas procuram dar mais ênfase aos princípios do que às regras detalhadas, apesar de algumas vezes isso não ser bem seguido, principalmente em situações muito difíceis e novas, como no caso dos instrumentos financeiros avaliados a mercado.

Segue a filosofia, é claro, da true and fair view e da representação econômica.

A convergência com as normas internacionais de contabilidade sinaliza a busca por informação transparente e verdadeira e caminha no sentido da interpretação econômica dos fatos, baseando-se nos principles oriented, objetivo este perseguido pelo IASB.

A alteração do modelo contábil pode acarretar consequências econômicas. De acordo com Hendriksen e Breda (1999), há inúmeros exemplos de consequências econômicas diretas e indiretas decorrentes das regras de contabilidade, como por exemplo, se alguém é obrigado por um novo padrão contábil a divulgar situação financeira inferior à esperada, os acionistas poderão ser prejudicados com a queda do preço da ação; os prêmios de altos executivos também cairiam. Qualquer mudança na regra contábil, portanto, pode ter uma série de 
impactos econômicos importantes sobre grande número de interessados nessas informações contábeis.

Isso, somado aos diversos eventos econômicos recentes, com destaque para a crise nos mercados financeiros americano e europeu com reflexo em toda a economia mundial, deixa clara a necessidade da busca constante de aperfeiçoamento dos modelos contábeis no que se refere à evidenciação da realidade econômica das empresas, como forma de se reduzir o risco sistêmico.

A alteração prevista na legislação brasileira pode ser aplicada a todos os mercados, incluindo-se o de energia elétrica, haja vista que demonstrações financeiras que levem a interpretações equivocadas quanto à saúde financeira da empresa distribuidora podem levar à perda de recursos privados e públicos, além de gerar uma visão distorcida do negócio para os investidores institucionais.

No mercado de energia elétrica no Brasil, as formas de registro, contabilização e evidenciação dos fatos econômicos relativos ao contrato de concessão do setor elétrico, seguem a legislação societária (Lei n 6.404/76), a legislação fiscal, os normativos emitidos pela Comissão de Valores Mobiliários - CVM e os normativos emitidos pelo órgão regulador do setor.

Os contratos de concessão de serviços públicos de energia elétrica celebrados entre o poder concedente e a empresa distribuidora são contabilizados e evidenciados de maneira similar à aquisição de uma empresa privada destinada à prestação do serviço.

O processo de assinatura dos contratos de concessão no Brasil aconteceu no contexto das privatizações ocorridas na década de 1990, período em que foram criadas as primeiras agências reguladoras, configuradas como entes públicos e dotadas de independência em relação ao poder executivo. Dessa forma, o Brasil vivenciou naqueles anos mudanças no padrão de intervenção do estado na economia.

No setor elétrico, para que o novo ambiente institucional fosse instalado, foi criada a Agência Nacional de Energia Elétrica - ANEEL com a finalidade, entre outras, de regular e fiscalizar os serviços públicos concedidos.

Nesse contexto, o uso da contabilidade como instrumento de tomada de decisão e de demonstração da situação patrimonial das empresas reguladas tem suporte no próprio objetivo da contabilidade, conforme consideram Iudicíbus, Martins e Gelbcke (2007, p. 30):

Os objetivos da contabilidade devem ser aderentes de alguma forma explícita ou implícita, àquilo que o usuário considera como elementos importantes para seu processo decisório. Não tem sentido ou razão de ser a contabilidade como uma disciplina neutra, que se contenta em perseguir esterilmente uma sua verdade ou 
beleza. A verdade da contabilidade reside em ser instrumento útil para a tomada de decisões pelo usuário, tendo em vista a entidade.

Sobre isso, cita-se também a afirmação de Hendriksen e Breda (1999) que dizem que sem dúvida um dos principais objetivos da contabilidade é a apresentação de um resumo dos recursos e das obrigações de uma empresa aos acionistas e outros investidores, em períodos de tempo, sob a forma de demonstração de posição financeira.

Ao ganhar escala o uso da contabilidade para tomada de decisões por parte dos usuários torna-se objeto de estudo. Assim, afirmam Iudicíbus, Martins e Gelbcke (2007, p. 31):

... que uma forma prática de verificar se a contabilidade está alcançando seus objetivos, é pesquisar, periodicamente, qual o grau de utilização das demonstrações contábeis por parte de grupos de usuários para os quais, de antemão, se acredita que as demonstrações contábeis devem ser de grande utilidade.

Nesse sentido, no que se refere à contabilidade específica das distribuidoras de energia elétrica, esta se encontra delineada e estabelecida no Manual de Contabilidade do Serviço Público de Energia Elétrica, estabelecido por meio da Resolução Aneel n ${ }^{0}$ 441/2000. Dentre os objetivos apresentados por esse Manual verifica-se que a contabilidade tem a finalidade de controle, monitoramento e fiscalização da atividade concedida (MANUAL DE CONTABILIDADE DO SERVIÇO PÚBLICO DE ENERGIA ELÉTRICA, 2001).

De acordo com o preâmbulo do referido Manual, além das disposições contidas na Lei $\mathrm{n}^{\mathrm{o}}$ 6.404/1976, foram consideradas para sua elaboração disposições e normas emanadas dos seguintes órgãos e entidades: Conselho Federal de Contabilidade - CFC; Instituto dos Auditores Independentes do Brasil - IBRACON; e Comissão de Valores Mobiliários - CVM.

Assim, ao seguir a legislação societária, as alterações trazidas pela Lei 11.638/2007 e pela Medida Provisória 449/2008 ${ }^{1}$ afetam a contabilidade específica do setor elétrico.

Mesmo com o poder normativo da Lei 11.638/2007, espera-se que a convergência para os padrões internacionais de contabilidade se dê de forma paulatina, visto que os normativos emitidos pelo IASB precisam de interpretação e da respectiva disseminação no ambiente contábil brasileiro.

No âmbito das normatizações contábeis, o IASB apresenta um corpo interpretativo, o International Reporting Interpretations Committee, que tem como função revisar as questões não especificamente abordadas nas normas ou abordadas de forma insatisfatória, buscando

\footnotetext{
1 A Medida Provisória 449/2008, altera a legislação tributária federal relativa ao parcelamento ordinário de débitos tributários, concede remissão nos casos em que especifica, institui regime tributário de transição e dá outras providências.
} 
um consenso ao tratamento adequado. Esse Comitê emite as interpretações chamadas de International Financial Reporting Interpretations Committee - IFRICs ${ }^{2}$.

Dentre as normas emitidas pelo IASB relativas à forma de evidenciação dos contratos de concessões existe o Standing Interpretations Committee - $\operatorname{SIC}^{3} 29$ - Service Concession Arrangements: Disclosures. A interpretação direcionada para contratos de concessão de serviços é a Interpretation 12 - Service Concession Arrangements (IFRIC 12), que orienta a contabilização, estabelecendo princípios gerais sobre o reconhecimento e mensuração dos ativos, passivos, receitas e despesas decorrentes do contrato que envolve esse tipo de prestação de serviço.

$\mathrm{Na}$ direção da harmonização com os padrões internacionais de contabilidade é importante ressaltar o papel do Comitê de Pronunciamentos Contábeis - CPC, criado em 2005, que tem como objetivo:

\begin{abstract}
... o estudo, o preparo e a emissão de Pronunciamentos Técnicos sobre procedimentos de Contabilidade e a divulgação de informações dessa natureza, para permitir a emissão de normas pela entidade reguladora brasileira, visando à centralização e uniformização do seu processo de produção, levando sempre em conta a convergência da Contabilidade Brasileira aos padrões internacionais (COMITÊ DE PRONUNCIAMENTOS CONTÁBEIS, 2007, p. 12).
\end{abstract}

Essa convergência busca a melhor forma de evidenciar nas demonstrações financeiras a essência econômica das transações ocorridas nas entidades. Cabe ressaltar que conforme divulgado no website do $\mathrm{CPC}^{4}$, a IFRIC 12 está na pauta de discussão daquele comitê, referente ao programa de trabalho 2008 a 2010.

Atualmente a contabilidade utilizada pelo regulador tem a finalidade de controle e monitoramento da atividade concedida. A Aneel o faz em atendimento às suas funções regulatórias, disciplinadas pela Lei $\mathrm{n}^{\mathrm{o}} \mathbf{9 . 4 2 7 ^ { 5 }}$, de 26/12/1996, quais sejam a regulação e fiscalização dos serviços públicos de energia elétrica. O papel da contabilidade no processo de regulação pode ser visualizado mais especificamente em dois momentos distintos: na fiscalização das demonstrações financeiras e na fixação de preços (tarifas).

Na fixação dos preços, segundo a Resolução Aneel 24/2006, a formação da receita via tarifa garante o equilíbrio econômico-financeiro do ente regulado, sendo isso pactuado no

\footnotetext{
${ }^{2}$ IFRIC é o comitê de interpretações ligado ao IASB que emite as interpretações técnicas oficiais.

${ }^{3} \mathrm{O}$ Standing Interpretations Committee - SIC é um comitê que desempenhava funções semelhantes às do atual IFRIC.

${ }^{4}$ Disponível em: <www.cpc.org.br/>. Acesso em: 18/11/2008.

${ }^{5}$ Lei $\mathrm{n}^{\mathrm{o}}$ 9.427, de 26 de dezembro de 1996, que institui a Agência Nacional de Energia Elétrica - ANEEL e estabelece no art. $3^{-0}$ que a Agência tem por finalidade a regulação e fiscalização das concessões de energia elétrica. Compete também a ela efetuar o controle das tarifas de distribuição através da homologação de reajustes e da execução dos processos de revisão tarifária periódica e extraordinária.
} 
contrato de concessão. Na fiscalização, a atuação da contabilidade se refere ao monitoramento econômico-financeiro da concessão expresso nas demonstrações financeiras, as quais devem permitir visualizar a realidade da empresa, sua rentabilidade, endividamento e estrutura de capital e, ainda, propiciar análises do desempenho por parte dos agentes financeiros e investidores.

Os dois momentos citados acima se referem à fixação e manutenção do equilíbrio econômico-financeiro - EEF pactuado no contrato de concessão entre ente público e ente privado, através da regulação tarifária (formação de preço), e a sua manutenção através do monitoramento e fiscalização. Dessa forma, são considerados momentos relevantes no processo regulatório em questão.

No entanto, apesar desse equilíbrio estar declarado na lei de criação do órgão regulador e nos contratos de concessão, estes não o definem. Assim, cabe aos agentes e principalmente ao regulador a interpretação do que venha a ser o EEF.

Diante do exposto e considerando a utilização da contabilidade pelo regulador nas suas funções de controle, monitoramento e fiscalização da atividade concedida, visando à fixação e manutenção do equilíbrio econômico-financeiro, a opção pela convergência às normas contábeis internacionais por parte da contabilidade regulatória pode contribuir para a identificação desse equilíbrio, podendo ainda impactar as demonstrações financeiras publicadas pelas empresas que trabalham sob o regime de concessão, em razão das interpretações internacionais serem divergentes da forma de tratamento e mensuração atual dos contratos de concessão no Brasil.

A aplicação da contabilidade regulatória afeta a regulação econômica, as informações aos usuários da própria contabilidade societária e, portanto, o desempenho relativo das empresas no mercado de capitais. Além disso, a evidenciação da realidade econômica dessas empresas é importante, pois dela depende o desenvolvimento do mercado de energia elétrica decorrente do interesse na realização de novos investimentos na área pela iniciativa privada e a satisfação do consumidor final por meio do pagamento de preços tarifários justos pelo recebimento de um serviço de boa qualidade.

Dessa forma, o que se analisa neste trabalho é a contabilidade regulatória como instrumento de regulação econômica e sua contribuição na identificação do equilíbrio econômico-financeiro das empresas desse setor, haja vista a possibilidade de alteração do modelo contábil atual para o novo modelo, as especificidades decorrentes de sua atuação em um mercado regulado, com características definidas em leis próprias do setor e, ainda, com base em condições estabelecidas em um contrato de concessão. 


\subsection{PROBLEMA E QUESTÃO DA PESQUISA}

O problema a ser tratado se refere à contribuição da contabilidade nas funções regulatórias e seu reflexo na evidenciação do equilíbrio econômico-financeiro previsto nos contratos de concessão, haja vista a possibilidade da adoção de um novo modelo contábil.

Portanto, a questão problema desta pesquisa é a seguinte:

Qual o potencialidade da evidenciação do equilíbrio econômico e financeiro dos contratos de concessão de distribuição do setor elétrico brasileiro pelas demonstrações contábeis, haja vista a alteração do modelo contábil?

Neste trabalho, a palavra potencialidade é empregada com o significado de capacidade; a palavra evidenciação é empregada no sentido de tornar algo evidente, esclarecido, verificado; e a palavra identificação será empregada com o significado de estabelecer a identidade, torná-la reconhecível.

\subsection{OBJETIVO GERAL DA PESQUISA}

Em função da questão de pesquisa anteriormente especificada, o objetivo geral deste estudo é analisar a contabilidade regulatória como instrumento de regulação econômica no setor de distribuição de energia elétrica brasileiro e demonstrar a potencialidade da identificação do equilíbrio econômico-financeiro previsto nos contratos de concessão, pelas demonstrações contábeis, haja vista a adoção de um novo modelo contábil, estabelecido pela Lei $11.638 / 2007$.

\subsection{JUSTIFICATIVA}

Conforme citado na introdução deste trabalho, as alterações nos modelos contábeis causam diversas consequências econômicas, como a queda do preço acionário, a redução da remuneração dos acionistas, dentre outras (Hendricksen e Breda, 1999). Somam-se a isso os diversos eventos econômicos recentes, com destaque para a crise nos mercados financeiros americano e europeu que refletiram em toda a economia mundial, reafirmando a necessidade da busca constante de aperfeiçoamento dos modelos contábeis no que se refere à evidenciação da realidade econômica das empresas, como forma de mitigar o risco sistêmico. 
Isso comprova a importância do propósito da Lei 11.638/2007, ao levar à convergência dos padrões contábeis na busca da melhor forma de se evidenciar nas demonstrações financeiras a essência econômica das transações e a realidade econômicofinanceira das entidades.

Portanto, nota-se que a contribuição pretendida é relevante na medida em que se observa que as informações contábeis afetam a regulação econômica, a definição do custo das tarifas de energia elétrica, que por sua vez afeta custos de produção e padrões de consumo da economia como um todo.

Assim, a real demonstração da essência econômica é subsídio fundamental, em última instância, pela existência de um setor com empresas saudáveis, com prestação de serviço público com qualidade e preços justos para seus usuários.

A evidenciação do equilíbrio econômico-financeiro das empresas do setor elétrico é relevante na medida em que dela dependem: o órgão regulador para a definição de políticas públicas; o investidor privado no que se refere ao interesse para a realização de novos investimentos na área; o mercado de capitais na condição de financiador do desenvolvimento do mercado de energia; e, por fim, à sociedade em geral, na condição de usuária do serviço.

\subsection{DELIMITAÇÃO DO ESTUDO}

O trabalho se restringe ao estudo do novo modelo contábil pela contabilidade regulatória do setor elétrico brasileiro, considerando o documento: interpretação - IFRIC 12 Service Concession Arrangements, emitido pelo International Accounting Standards BoardIASB.

As empresas estudadas são as distribuidoras do serviço de distribuição de energia elétrica constituídas na forma de sociedades por ações, sob a égide da Lei 6.404/1976, alterada pela Lei 11.638/2007.

O estudo se concentra no estudo da contabilidade para o usuário regulador, utilizando os modelos contábeis e formas de registros aplicados no período de 1995 até 2008.

Para finalizar é importante ressaltar que o trabalho se delimita a analise dos investimentos iniciais e novos investimentos e ao processo de revisão tarifária ocorridos durante a vigência de um contrato de concessão do serviço de distribuição de energia elétrica, não visando verificar seus efeitos ao término do contrato.

\subsection{METODOLOGIA GERAL}


Segundo Collis e Hussey (2005), as pesquisas podem ser classificadas de acordo com seus objetivos. Em relação aos objetivos, esta pesquisa pode ser classificada como analíticadescritiva. Descritiva, pois descreve o comportamento dos fenômenos para identificar e obter informações sobre as características de um determinado problema ou questão, e analítica, pois continua a pesquisa descritiva analisando e explicando por que ou como os fatos estão acontecendo. Esse tipo de pesquisa tem como objetivo entender os fenômenos (COLLIS E HUSSEY, 2005).

Além disso, este trabalho também procura ampliar o conhecimento a respeito do processo de utilização da contabilidade na regulação econômica do setor de energia elétrica, com base em análises de dados passados, podendo, desse modo, ser considerado exploratório, pois visa proporcionar maior familiaridade com o problema.

Os procedimentos metodológicos utilizados na sua realização são:

1) revisão bibliográfica, visando identificar os principais objetivos da contabilidade societária e da contabilidade regulatória no setor elétrico;

2) análise dos principais normativos internacionais referentes a concessões, visando identificar os padrões e interpretações internacionais na contabilização das concessões no setor elétrico;

3) identificação das ferramentas fornecidas pela contabilidade no processo de regulação econômica do setor elétrico;

4) análise comparativa do modelo societário atual versus modelo elaborado com base nas interpretações internacionais sobre formas de contabilização das concessões no setor elétrico. Para atender ao objetivo da pesquisa, a análise foi feita com base em simulação comparativa de dois exemplos entre o modelo contábil societário atual e o novo modelo elaborado de acordo com as interpretações internacionais;

5) identificação da potencialidade da adoção das interpretações internacionais no processo de regulação econômica do setor elétrico brasileiro, visando analisar qual a contribuição dos novos padrões contábeis na evidenciação do equilíbrio econômico-financeiro presente nos contratos de concessão. 


\subsection{DISTRIBUIÇÃO TEMÁTICA E ORGANIZAÇÃO DO TRABALHO}

O trabalho está estruturado em cinco capítulos, incluindo este introdutório que apresenta o problema e a questão de pesquisa, o objetivo e a apresentação da estrutura geral dos demais capítulos.

No segundo capítulo é desenvolvido o referencial teórico sobre contabilidade societária e regulatória e são demonstradas algumas das mudanças no ambiente societário atual decorrente da publicação da Lei 11.638/2007.

No terceiro capítulo são apresentados o ambiente institucional regulatório em que estão inseridas as distribuidoras de energia elétrica, uma discussão sobre o equilíbrio econômico-financeiro dos contratos de concessão e os subsídios contábeis para as funções regulatórias com o objetivo de identificar o papel da contabilidade regulatória na regulação econômica do setor de energia elétrica.

No quarto capítulo é analisada a potencialidade de adoção do novo modelo contábil para a contabilidade regulatória com base na análise comparativa da simulação dos fatos econômicos decorrentes de um contrato de concessão (investimentos e revisão tarifária periódica), pelos demonstrativos financeiros de acordo com o modelo societário atual e o novo modelo elaborado com base nas normas internacionais de contabilidade (IFRIC-12).

Por fim, no capítulo quinto, são apresentadas as considerações finais, as conclusões obtidas e as sugestões para investigações futuras. 


\section{CONTABILIDADE REGULATÓRIA E SOCIETÁRIA}

O objetivo deste capítulo é apresentar os aspectos da contabilidade regulatória aplicada ao setor elétrico, o tratamento decorrente da contabilidade societária com as mudanças trazidas pela Lei 11.638/2007, com foco nas empresas sob regime de concessão do serviço de distribuição de energia elétrica, haja vista ser essa a origem dos parâmetros para a análise proposta neste trabalho.

\subsection{CONTABILIDADE REGULATÓRIA}

Sobre alternativas de pesquisa em contabilidade aplicáveis aos serviços públicos, Broadbent e Guthrie (1992) sugerem que historicamente a contabilidade e a auditoria nesse setor foram muito focadas em "proibição, cumprimento e controle". Eles associam isso ao seguimento de regras técnicas, porém argumentam que há um significativo corpo de literatura defendendo que a contabilidade não deve ser uma atividade puramente técnica e que também deve ser ativamente envolvida na construção das organizações e nas suas estratégias.

Cooper (1998), em um artigo publicado sobre controle, contabilidade e suas implicações nas empresas reguladas, apresenta uma discussão sobre o papel da contabilidade e faz uma revisão de alguns trabalhos que evidenciam a utilidade dos demonstrativos financeiros para a regulação econômica.

Segundo o autor, dentre as visões sobre o papel da informação contábil destacam-se que:

a) uma das preocupações-chave da contabilidade é a previsão de informação;

b) a contabilidade é uma linguagem capaz de traduzir muitos pedaços díspares em termos financeiros comuns;

c) a comunicação de informação é, talvez, o mais fundamental papel da contabilidade.

Ao considerar que a assimetria de informação ${ }^{6}$ é amplamente identificada como um problema fundamental para a regulação, Cooper (1998) ressalta a importância de informação suficiente para o regulador para que este seja capaz de fazer o seu trabalho corretamente.

\footnotetext{
${ }^{6}$ A assimetria de informação entre duas partes que transacionam ocorre quando uma parte detém mais informações do que a outra, seja ex ante em relação às características do que está sendo comprado ou vendido,
} 
Nesse sentido, entende ele que, com o passar do tempo, há uma tendência para os reguladores invadirem cada vez mais as áreas de informação. Não só aquelas que incluem preço (investimento) e taxa de retorno (custo de capital), mas também informações sobre qualidade, serviço e acesso.

Assim, é nesse contexto que a contabilidade contribui com a demonstração correta da essência econômica dos fatos, apresentando indicadores de desempenho relativos a essas e outras informações que são de suma importância para o regulador no exercício do seu dever.

Cooper (1998) nota que um problema determinante está na estimação da base do valor do investimento e que isso deveria depender do quanto os investidores pagaram na privatização, bem como de outros investimentos feitos posteriormente. Conclui ele que as indústrias reguladas acrescentaram uma nova perspectiva para o debate acerca de assuntos de contabilidade, como custo corrente e indicadores de desempenho.

Cooper (1998) também traz a discussão sobre a conveniência da utilização de modelos financeiros que tentam prever um futuro de longo prazo e um ambiente ideal no qual o papel da contabilidade nas organizações em mudança deve ser estudado. Adiciona, ainda, que as lições aprendidas sobre o desempenho das indústrias reguladas e o uso de informação contábil nesse ambiente podem bem servir para fixar os padrões para outras indústrias.

Sobre o uso da contabilidade como ferramenta de aferição de desempenho operacional, Gowland e Aiken (2005), em uma pesquisa sobre o papel da informação contábil e medidas de desempenho nas companhias privatizadas da Austrália, concluíram que as informações contábeis das empresas que passaram por mudanças depois da privatização foram muito válidas para os acionistas não somente para evidenciar melhorias de desempenho operacional como também na produção de informações adicionais para a tomada de decisão, conferindo ênfase ao papel da contabilidade e dando-lhe um caráter preditivo.

Rehbein, Engelmann e Gonçalves (2008), em um trabalho sobre o uso de índices padrões na contabilidade regulatória, buscam evidenciar a aplicabilidade de índices econômico-financeiros padronizados na atividade de prestação de serviços de transporte rodoviário intermunicipal metropolitano, como forma de sinalizar ao agente regulador possíveis ajustes operacionais que mereçam ser implementados para o efetivo exercício da regulação.

seja ex post em relação ao comportamento dos indivíduos depois de firmado o contrato. Os modelos de seleção adversa tratam de problemas de informações imperfeitas associadas ao primeiro caso, enquanto que os de risco moral abordam os problemas de informações relacionados ao segundo (Stiglitz, 1985). 
Em seu trabalho os autores afirmam que a contabilidade regulatória é um instrumento que qualifica o trabalho dos reguladores, permitindo especialmente o uso dos indicadores econômico-financeiros para subsidiar a sua tomada de decisão na busca da garantia da continuidade, regularidade, eficiência, segurança, atualidade e generalidade dos serviços prestados pelas distribuidoras do serviço público de transporte de passageiros.

Para desenvolver o estudo sobre uso de índices, Rehbein, Engelmann e Gonçalves (2008) utilizaram as informações contábeis do ano de 2003 a 2006 das empresas distribuidoras do serviço público de transporte intermunicipal de passageiros da região metropolitana de Porto Alegre (RS).

A partir dos índices econômico-financeiros das empresas individuais (cento e sete empresas), guardadas as características de semelhança quanto ao porte e área de atuação, foram calculados estatisticamente os decis do setor para cada indicador, utilizando-se o programa SPSS 15.0. Definidos os decis, os indicadores das empresas que compõem a região metropolitana de Porto Alegre (RS) foram classificados de acordo com os conceitos atribuídos na escala proposta por Matarazzo (1998): péssimo, deficiente, fraco, razoável, satisfatório, bom e ótimo.

A conclusão apresentada pelos autores é a de que os indicadores funcionam como um "exame" ou um "alerta", sendo necessário estudar de forma mais detalhada o comportamento dos mesmos considerando uma série histórica e quais os fatores que impactam os indicadores.

Em que pese a metodologia usada pelos autores quanto a limitações de uso de indicadores que comparam empresas de estruturas e formas de operação distintas, vale a reflexão sobre a preocupação pertinente a respeito dos reguladores expandirem suas pesquisas em torno de informações contábeis que auxiliem no processo de regulação, com vistas à guarda do equilíbrio econômico-financeiro da concessão.

Aspecto importante é apresentado por Rehbein, Engelmann e Gonçalves (2008) ao afirmarem que a contabilidade regulatória visa auxiliar nos controles das atividades delegadas pelo poder público, reduzindo a assimetria da informação entre regulado e regulador, representando um avanço em relação à contabilidade financeira. Acrescentam, ainda, que a contabilidade regulatória permite a interpretação das informações econômico-financeiras do concessionário, visando apoiar os estudos sobre o equilíbrio econômico-financeiro dos contratos e a modicidade tarifária. 
Rehbein e Gonçalves (2008) analisaram a contabilidade regulatória no contexto do marco regulatório dos serviços de saneamento básico, Lei $n^{\mathrm{o}}$ 11.445/2007 ${ }^{7}$. A abordagem do tema desenvolve-se mediante a reflexão sobre as necessidades de adoção de norma de referência orientadora para a instituição de controles no âmbito da contabilidade regulatória para a atividade de saneamento.

$\mathrm{Na}$ análise apresentada, eles afirmam que as agências reguladoras brasileiras foram criadas, entre outros motivos, com a finalidade de garantir um ambiente de equilíbrio na prestação dos serviços, harmonizando os interesses dos usuários, distribuidoras e poder concedente de acordo com os contratos de concessão firmados.

Dessa forma, o controle da atividade regulada é uma forma indireta de accountability, relacionando-se ao processo de prestação de contas.

Nesse sentido, destacam Rehbein e Gonçalves (2008), as agências reguladoras necessitam de informações detalhadas, passíveis de certificação, para definir tarifas que mantenham o equilíbrio econômico-financeiro dos contratos sem prejuízo da qualidade dos serviços. Neste contexto, a contabilidade possui interface direta com essas necessidades, pois registra e transmite aos usuários informações econômicas e financeiras, além de outras relacionadas, por exemplo, à produtividade.

As informações consistentes e fidedignas disponibilizadas pela contabilidade são fundamentais para a elaboração das planilhas tarifárias, permitindo uma análise segura da composição dos preços dos serviços públicos regulados.

Como conclusão, os autores apresentam que, para satisfazer às demandas das agências, a elaboração da informação contábil deve observar normas específicas para o setor regulado. No caso da atividade de saneamento, estes sugerem a criação de um manual de contabilidade próprio do setor, haja vista a complexidade de informações necessárias para se atender aos objetivos regulatórios.

Destacam também que a contabilidade brasileira passa por um importante momento em virtude da alteração da Lei das Sociedades por Ações na busca da convergência às normas internacionais de contabilidade, tendo, portanto, para o setor de saneamento um duplo desafio aos reguladores na área contábil: ao mesmo tempo em que tratam de implementar a visão do marco regulatório da atividade, também precisam dedicar-se à absorção de novas práticas contábeis.

\footnotetext{
${ }^{7}$ Lei $\mathrm{n}^{\mathrm{o}}$ 11.445, de 5 de janeiro de 2007: estabelece diretrizes nacionais para o saneamento básico.
} 
A exemplo de outros setores, como o de energia elétrica e o de telecomunicações, o setor de saneamento vem presenciando, com a edição do marco regulatório em 2007, um processo de adequação e normatização do regime de regulação.

Ao abordar o tema contabilidade regulatória e apresentar um modelo de plano de contas que sistematiza as informações econômico-financeiras sobre controle e monitoramento, esses autores contribuem sobremaneira para o desenvolvimento da contabilidade regulatória, fortalecendo a contabilidade como um todo.

Nesse sentido, os autores reforçam a importância do papel da contabilidade em ambientes regulados como instrumento de provisão de informação de caráter preditivo, onde várias decisões têm como base os dados fornecidos pelos demonstrativos financeiros.

Sendo assim, devido à especificidade e com o objetivo de padronização, uniformização e comparabilidade dos entes regulados, alguns setores adotaram regras contábeis específicas.

Para se ter uma idéia, nos setores de infra-estrutura o estabelecimento de normas contábeis para padronizar os registros das empresas reguladas teve início em 1959, com a Resolução do Comitê Nacional de Petróleo n 03 que aprovou o Plano de Contabilidade das Refinarias de Petróleo, publicada no DOU de 23/05/99.

Um movimento de reguladores de alguns países no sentido da instituição de regras, procedimentos e normas contábeis, chamada de contabilidade regulatória, é o da Associação de Entes Reguladores de Água Potável e Saneamento das Américas - ADERASA, que fomenta a colaboração e intercâmbio entre os entes reguladores de 13 países latinoamericanos: Argentina, Bolívia, Brasil, Chile, Colômbia, Costa Rica, Equador, Honduras, Nicarágua, Panamá, Paraguai, Peru e Uruguai. Seu objetivo maior é o desenvolvimento de uma ferramenta regulatória contábil específica para a área de saneamento ${ }^{8}$.

O regulador de água do Reino Unido (OFWAT ${ }^{9}$ ) tem suas orientações e procedimentos que visam definir aos entes regulados a rotina contábil a ser adotada bem como permitir ao regulador o controle e o monitoramento da atividade concedida, no chamado "Regulatory accounting guidelines" 10 .

\footnotetext{
${ }^{8}$ Segundo Marchioretto (2006): "o Projeto de Contabilidade Regulatória da ADERASA tem como propósito melhorar a informação dos entes reguladores dentro de suas competências, e diminuir a assimetria de informação, com enfoque nas melhores práticas internacionais com as realidades contábeis nacionais. O grupo de trabalho tem como objetivo buscar a estrutura de uma empresa ideal, para implantar a contabilidade regulatória na atividade de saneamento".

${ }^{9}$ Regulador econômico da indústria de água e esgoto da Inglaterra e País de Gales - OFWAT.

10 Disponível em: <https://www.ofwat.gov.uk/regulating/pap_con_ragsreview2.pdf?download=Download\#>. Acesso em: 16/12/2008.
} 
$\mathrm{Na}$ linha de padronização das informações contábeis, Iudícibus, Martins e Gelbcke (2007, p. 18) afirmam que cada empresa deverá elaborar seu plano de contas mediante a adaptação a suas peculiaridades de operação, necessidades internas, transações e contas específicas. Pode-se, então, inferir que a implementação de um plano de contas pelo regulador de um setor específico tem como objetivo padronizar e uniformizar o registro descritivo funcional das contas, obrigando as empresas reguladas a seguirem essa padronização.

$\mathrm{Na}$ medida em que o regulador emite normas que determinam a elaboração de demonstrativos adicionais aos da contabilidade societária ou apêndices a ela isso seria um dos passos para a identificação inicial de uma contabilidade regulatória.

No Brasil, em alguns setores de infra-estrutura, os órgãos reguladores (Aneel, Anatel, ANP, etc.) estabeleceram manuais de regras e procedimentos contábeis para viabilizar o controle e o gerenciamento econômico-financeiro da empresa distribuidora, de forma que também possam efetuar a fiscalização da prestação do serviço. Essa padronização tem como objetivo o controle e o acompanhamento por meio dos demonstrativos contábeis, orientando o bom desenvolvimento do negócio regulado.

Da forma como se apresenta, a contabilidade regulatória é um meio de controle da atividade regulada que visa reduzir a assimetria de informação entre o regulado e o regulador, otimizando as informações e viabilizando a sua utilização para cumprimento das funções regulatórias, em especial a fiscalização do equilíbrio econômico-financeiro previsto no contrato da concessão e a fixação de preços tarifários.

No caso do setor elétrico, para as empresas organizadas em sociedades por ações, grupo de interesse deste trabalho, as demonstrações financeiras publicadas por essas empresas estão sob regulamentação da legislação contábil societária, das normas emitidas pela Comissão de Valores Mobiliários - CVM e da contabilidade regulatória específica disciplinada pelo órgão regulador.

\subsubsection{Contabilidade regulatória do setor elétrico brasileiro}

No que se refere à contabilidade das distribuidoras de energia elétrica brasileiras, a primeira apresentação estruturada de um plano de contas do setor foi instituída pelo Decreto n⿳⺈ 28.545, de 24/08/1950, sob o título "Classificação de Contas para Empresas de Energia Elétrica", que vigorou até 31/12/1978. 
Com a publicação da Lei n⿳ำ 6.404, de 15/12/1976, o Departamento Nacional de Águas e Energia Elétrica - DNAEE ${ }^{11}$ promoveu a primeira reformulação do conjunto de normas contidas no Decreto $\mathrm{n}^{\mathrm{o}}$ 28.545/1950, resultando em significativas alterações dos procedimentos contábeis adotados pelas empresas do setor de energia elétrica.

Foi publicado, então, um novo plano de contas instituído pelo Decreto n⿳0 82.962, de 29/12/1978. Esse plano de contas representou um marco importantíssimo para o setor elétrico, uma vez que consolidou procedimentos contábeis já consagrados e introduziu novos conceitos com base na legislação vigente à época. O plano de contas publicado em 1978 vigorou por 16 anos.

No ano de 1994, o DNAEE publicou a Portaria n⿳0 815, de 30/11/1994, determinando aos concessionários do serviço público de energia elétrica que atualizassem e mantivessem organizado o cadastro da propriedade em função do serviço concedido, em conformidade com as "Instruções para Contabilização e Controle do Ativo Imobilizado".

Essa portaria estabeleceu instruções para a organização do inventário da propriedade dos concessionários de energia elétrica e definiu quais adições, retiradas e substituições do acervo físico afetariam o imobilizado em serviço e quais afetariam a despesa. Essa Portaria está em vigor até hoje.

Somente em 1996, com a criação da agência reguladora do setor, a Aneel, e com a publicação da Lei das Concessões, foi promovida a simplificação do plano de contas do setor, com a segmentação das contas por tipo de atividade (produção, transmissão e distribuição), o que permitiu a apuração do resultado contábil de cada segmento e de cada unidade de negócios, proporcionando maior transparência para o controle e acompanhamento do serviço concedido. Nesse novo contexto, o plano de contas foi totalmente modificado pela Resolução Aneel noํ0ㄹ, de 24/12/1997.

Quatro anos depois, em 2001, a Aneel promoveu nova reformulação do plano de contas com a publicação do Manual de Contabilidade do Setor Público de Energia Elétrica MCSPEE, tendo em vista o processo de privatização e a necessidade de se destacar claramente os dados e as informações referentes ao desempenho da concessão.

Observa-se, portanto, que o início da estruturação de contas para o setor elétrico data de 1950, revelando os esforços dos profissionais da área e do governo brasileiro no sentido de

\footnotetext{
${ }^{11}$ Departamento Nacional de Águas e Energia Elétrica - DNAEE: órgão regulador até 26 de dezembro de 1996, vinculado ao Ministério de Minas e Energia.
} 
obter informações padronizadas e coerentes com o objeto da concessão, visando ao controle e monitoramento através de relatórios econômico-financeiros.

\subsubsection{O Manual de Contabilidade do Serviço Público de Energia Elétrica - MCSPEE}

Em 2001, foi publicado o Manual de Contabilidade do Serviço Público de Energia Elétrica - MCSPEE, que reformulou o plano de contas do setor, apresentando um maior detalhamento das regras contábeis. Um dos argumentos apresentados para a reformulação foi a necessidade de absoluta transparência na divulgação de dados e informações sobre o desempenho das distribuidoras e permissionárias para uma grande variedade de partes interessadas (órgãos reguladores, acionistas, analistas, empregados, consumidores, instituições financeiras nacionais e internacionais, investidores nacionais e estrangeiros, credores e público em geral).

Segundo o MCSPEE (2001, p. 2), para a execução do projeto a Aneel contratou consultores externos e incorporou ao processo os contadores das empresas de energia elétrica, além de contar com a participação da Associação Brasileira dos Contadores do Setor de Energia Elétrica - ABRACONEE, de membros do Conselho Federal de Contabilidade - CFC, do Conselho Regional de Contabilidade do Distrito Federal - CRC-DF, da Comissão de Valores Mobiliários - CVM, do Instituto dos Auditores Independentes do Brasil IBRACON, da Associação Brasileira dos Analistas do Mercado de Capitais - ABAMEC e de representantes da comunidade acadêmica com o objetivo de obter subsídios para elevar o nível técnico dos trabalhos. O Manual passou então por um processo de audiência pública no período de 22/08/2001 a 23/09/2001.

Isso comprova que o regulador buscou a participação dos diversos agentes institucionais com o objetivo de colher contribuições para o aperfeiçoamento das normas relativas à contabilização das distribuidoras de energia elétrica.

Instituído por meio da Resolução Aneel nº 444, de 26/10/2001, o MCSPEE contém a padronização das normas de edição e publicação das demonstrações contábeis das empresas do setor de energia elétrica brasileiro.

De acordo com o preâmbulo desse normativo, além das disposições contidas na Lei $\mathrm{n}^{\mathrm{o}}$ 6.404/1976, foram também consideradas na sua confecção as disposições e normas julgadas aplicáveis emanadas dos seguintes órgãos e entidades: Agência Nacional de Energia Elétrica - ANEEL, Conselho Federal de Contabilidade - CFC, Instituto dos Auditores Independentes 
do Brasil - IBRACON, Comissão de Valores Mobiliários - CVM e Comitê de Normas Internacionais de Contabilidade (International Accounting Standards Committee - IASC).

De acordo com o Manual (2001, p. 13), ele foi elaborado tendo como principais objetivos:

a) contribuir para a avaliação do equilíbrio econômico-financeiro da concessão atribuída pela União Federal;

b) padronizar os procedimentos contábeis adotados pelas distribuidoras e permissionárias do serviço público de energia elétrica, permitindo o controle e o acompanhamento das respectivas atividades objeto da concessão e permissão pela Aneel;

c) atender aos preceitos da legislação comercial brasileira, além da legislação específica do setor elétrico e do ordenamento jurídico-societário, bem como a plena observância dos princípios fundamentais de contabilidade ${ }^{12}$;

d) permitir a elaboração das demonstrações contábeis e correspondentes notas explicativas, do relatório da administração e das informações complementares que necessitem de divulgação para atendimento de dispositivos da legislação societária brasileira, da legislação aplicável às companhias abertas, da legislação aplicável ao setor de energia elétrica e para atendimento das necessidades de investidores, acionistas, instituições financeiras, credores, consumidores, órgãos reguladores e público em geral;

e) permitir a apuração do resultado das atividades de geração, transmissão, distribuição e comercialização; e

f) contribuir para a avaliação da análise do equilíbrio econômico-financeiro da distribuidora e permissionária.

De acordo com os objetivos apresentados no próprio Manual de Contabilidade, observa-se a busca de padronização face à diversidade de informações a serem apropriadas pelos regulados de forma a atender aos objetivos buscados pela própria contabilidade, qual seja permitir que seu usuário seja suprido de informação suficiente para a tomada de decisão.

\footnotetext{
12 Segundo o MCSPEE (2001, p. 36), princípios fundamentais de contabilidade a que se refere são aqueles catalogados na Resolução no 750, de 29 de dezembro de 1993, do Conselho Federal de Contabilidade - CFC, de acordo com o que dispõe o art. 3, são: da entidade; da continuidade; da oportunidade; do registro pelo valor original; da atualização monetária; da competência e da prudência.
} 
Dessa forma, para disciplinar, orientar e controlar a atividade concedida, o Manual descreve os procedimentos e regras a serem seguidas nas suas 828 páginas com um elevado grau de detalhamento. Os pilares básicos de aplicação estão estabelecidos nas Instruções Gerais - IG, nas Instruções Contábeis - IC e no plano de contas propriamente dito, da seguinte forma:

a) Instruções Gerais - IG, em número de 23, que disciplinam os conceitos, a segregação de atividades relacionadas ao objeto concedido, à elaboração de relatórios financeiros e os períodos de publicação e envio à Aneel;

b) Instruções Contábeis - IC, em número de 33, que disciplinam a forma de contabilização e escrituração das contas, as técnicas de funcionamento e a forma das partidas contábeis;

c) Plano de Contas, que apresenta o elenco de contas, as técnicas de funcionamento e a natureza contábil;

d) roteiro para elaboração e divulgação das informações contábeis econômicofinanceiras e sociais; e

e) modelos de demonstrações.

\subsubsection{Instruções Gerais - IG}

Das vinte e três IG estabelecidas pelo Manual, as mais relevantes para este trabalho estão descritas a seguir.

As IG 1 a 3 disciplinam a obrigatoriedade por parte das firmas individuais, autarquias e pessoas jurídicas de direito público e privado, distribuidoras e permissionárias do serviço público de energia elétrica e, opcionalmente, os produtores independentes, de adoção das disposições contidas no Manual; a manutenção permanente e atualizada dos cadastros e controles da propriedade dos bens e instalações vinculados a concessão, os quais são passíveis de reversão à União; aspectos sobre lançamentos contábeis, os quais serão registrados de acordo com a legislação comercial com base em documentos hábeis e idôneos, segundo o regime de competência.

A IG 5 estabelece a obrigatoriedade das distribuidoras e das permissionárias de elaboração do Balancete Mensal Padronizado - BMP e o seu envio à Aneel no prazo máximo de 40 (quarenta) dias após findo o mês de competência; de elaboração e envio do Relatório de Informações Trimestrais - RIT no modelo estabelecido pelo órgão regulador, a ser encaminhado no prazo máximo de 45 (quarenta e cinco) dias após o término do trimestre de 
competência. Estabelece ainda o envio das demonstrações financeiras de encerramento do exercício, como sendo a Prestação Anual de Contas - PAC ${ }^{13}$.

Importante aspecto no que se refere ao controle da atividade concedida é apresentado na IG 8 , que estabelece às distribuidoras e às permissionárias que explorem atividades não vinculadas à concessão ${ }^{14}$ do serviço público de energia elétrica a manutenção de registros e controles em separado de todas as operações relacionadas com estas atividades.

É recomendado, com ênfase, que seja constituída outra sociedade para fins de exploração de atividades estranhas às da distribuidora ou permissionária de serviço público de energia elétrica. Enquadram-se nesse conceito também os empreendimentos conjuntos (consórcios) de qualquer condição e finalidade, assim como investimentos em outras sociedades.

A esse respeito ainda estabelece a IG que caberá à distribuidora ou permissionária definir critérios para a identificação e a segregação dos bens, direitos e obrigações, assim como para a apuração do respectivo resultado das operações relacionadas às atividades não vinculadas à concessão, devendo, entretanto, esses critérios serem apresentados para respectiva anuência do órgão regulador antes de sua aplicação (MCSPEE, 2001, p. 31).

Disciplina, ainda, o Manual que tais normas não prejudicam disposições específicas contidas em regulamentações que estabelecem a necessidade de anuência da Aneel para a realização de atividades estranhas ao objeto da concessão ou permissão.

A IG 13 estabelece que as distribuidoras e permissionárias procedam aos registros contábeis segregados por atividade de geração, transmissão, distribuição e comercialização, sendo que para as contas representativas do ativo imobilizado, do ativo diferido, das obrigações vinculadas à concessão do serviço público de energia elétrica, dos bens e direitos destinados a alienação e de resultado será efetuada em nível de $1^{\circ}$ grau $^{15}$.

\footnotetext{
${ }^{13}$ Segundo o MCSPEE (2001, p. 29), comporão a PAC: o Balanço Social, a Demonstração do Fluxo de Caixa, a Demonstração do Valor Adicionado e a Composição do Capital Social. Quando aplicável, as distribuidoras e permissionárias deverão enviar, também, o Relatório da Administração, o Parecer do Auditor Independente sobre as demonstrações contábeis, o Relatório de Recomendações dos Auditores Independentes para aprimoramento dos controles internos, o Parecer dos Auditores Independentes sobre as Mutações do Ativo Imobilizado, o Relatório do Conselho de Administração, o Parecer do Conselho Fiscal e as demonstrações contábeis de empreendimentos em condomínios e consórcios em função do serviço concedido.

${ }^{14}$ Entende-se por atividade não vinculada à concessão do serviço público de energia elétrica toda e qualquer operação realizada pela distribuidora e permissionária que não esteja relacionada diretamente ao objeto da concessão, ou seja, atividades empresariais desenvolvidas por meio de outros negócios que não os de Geração, Transmissão, Distribuição e Comercialização de energia elétrica (MCSPEE, 2001, p. 30).

${ }^{15}$ No plano de contas integrante do MCSPEE, a estrutura de cada conta é composta por uma parte numérica (código) e outra alfabética (título), não devendo ser alterada. A conta de $1^{\circ}$ grau ou conta, no seu conjunto, formará o razão geral ou razão sintético. As contas de $2^{-}, 3^{-}$e $4^{\underline{0}}$ graus ou subcontas, nos seus respectivos conjuntos, formarão o razão auxiliar ou razão analítico (MCSPEE, 2001, p. 24).
} 
As IG 14 a 18 definem as atividades de geração, distribuição, transmissão, administração e comercialização, como sendo:

a) geração: é composta pelas centrais geradoras e tem por finalidade o serviço de produção de energia elétrica, o qual consiste na transformação em energia elétrica de qualquer outra forma de energia;

b) distribuição: é composta de linhas, redes, subestações e demais equipamentos associados, em tensões inferiores a $230 \mathrm{kV}$ e tem por finalidade: (i) o serviço de distribuição de energia elétrica, que consiste no provimento do livre acesso ao sistema para os fornecedores e consumidores; (ii) permitir o fornecimento de energia a consumidores; e (iii) suprimento de energia elétrica a outras distribuidoras e permissionárias;

c) transmissão: é uma atividade regulada, concedida por meio de um contrato de concessão e feita por linhas e subestações que integram a Rede Básica ${ }^{16}$, bem como por outras instalações reguladas ou não;

d) administração: compreenderá todas as instalações da administração central da distribuidora ou permissionária, e tem por finalidade agregar os gastos da administração central de âmbito geral;

e) comercialização: compreende as atividades de compra e venda de energia elétrica, podendo também ser exercida por uma empresa constituída exclusivamente para prestar esse serviço. O imobilizado dessa atividade é composto de móveis e utensílios, equipamentos de informática e comunicação e demais bens necessários a sua atividade. Portanto, linhas, redes, subestações, transformadores e medidores não pertencem a essa atividade.

Por fim, na IG 21 são apresentados os procedimentos contábeis para a apuração do resultado e para a elaboração e apresentação das demonstrações financeiras, as quais devem atender aos conceitos e requisitos básicos aplicáveis a empresas que exerçam suas atividades no Brasil, sendo compatíveis com aqueles estabelecidos na legislação societária atualmente em vigor.

\footnotetext{
16 A Resolução ANEEL n. ${ }^{\circ}$ 433, de 10 de novembro de 2000, que fixou os requisitos para classificação de instalações de transmissão, estabelece que integram a Rede Básica as linhas de transmissão, os barramentos, os transformadores de potência e os equipamentos com tensão igual ou superior a $230 \mathrm{kV}$ integrantes do sistema interligado.
} 


\subsubsection{Instruções Contábeis - IC}

Quanto às IC, são apresentadas trinta e três e referem-se às contas contábeis que foram consideradas merecedoras de destaque, tais como, fornecedores, aplicações financeiras, questões ambientais, estoque, despesas pagas antecipadamente, provisão para devedores duvidosos, ativo imobilizado, bens e direitos destinados a alienação, depreciação, bens da União, comercialização de energia elétrica, reserva de lucros a realizar, etc.

As IC indicam como contabilizar. A título de exemplo, cita-se a instrução contábil referente à aplicação financeira:

O título derivado de aplicação financeira será contabilizado na conta adequada pelo custo de aquisição, e não pelo valor nominal, ou outro qualquer valor. O custo de aquisição incluirá o valor pago pelo título, mais a corretagem, emolumentos etc., porventura incidentes sobre o negócio (MCSPEE, 2001, p. 36).

Dessa forma é aplicado o mesmo procedimento para cada conta merecedora de destaque, sendo inserida para algumas uma descrição mais detalhada da forma de contabilização. É o caso da depreciação do ativo imobilizado, como bens e direitos destinados à alienação, cujas instruções especificam a adoção de um sistema de ordens em curso que representam um processo de registro, acompanhamento e controle para apuração de custos dentro do sistema contábil, composto conforme abaixo:

a) Ordem de Imobilização - ODI: representa um processo de registro, acompanhamento e controle de valores, que será utilizado para apuração do custo do acervo em função do serviço público de energia elétrica;

b) Ordem de Desativação - ODD: representa um processo de registro, acompanhamento e controle de valores, que será utilizado para apuração dos custos referentes à retirada (baixa) de bem integrante do ativo imobilizado. Cada ODD deverá estar vinculada a uma ODI;

c) Ordem de Alienação - ODA: representa um processo de registro, acompanhamento e controle de valores, que será utilizado para apuração dos custos de alienações de bens.

De acordo com o que disciplina o Manual de Contabilidade, os bens e direitos utilizados em função do serviço concedido serão cadastrados e controlados pela distribuidora e permissionária em sistemas auxiliares ou em registros suplementares por meio de Unidades de Cadastro - UC e Unidades de Adição e Retirada - UAR, por Ordem de Imobilização - ODI, 
conta contábil e data de transferência para o imobilizado em serviço. Define-se por:

a) Unidade de Cadastro - UC: a parcela dos bens integrantes do ativo imobilizado, que deve ser registrada individualmente no cadastro da propriedade;

b) Unidade de Adição e Retirada - UAR: a parcela ou o todo de uma Unidade de Cadastro - UC, que adicionada, retirada ou substituída, deve ser refletida nos registros contábeis do ativo imobilizado da distribuidora e da permissionária.

Esse sistema de ordens em curso demonstra o nível de controle que a distribuidora deverá ter para registrar seu inventário de bens do ativo imobilizado e prestar contas ao regulador. Tal controle demonstra a importância para o regulador dos bens que se destinam à prestação do serviço público de energia elétrica.

Outro destaque das IC é o caso da provisão para ajuste ao valor de recuperação de ativos. Esse item, segundo o MCSPEE (2001, p. 50), determina que os ativos constantes do balanço patrimonial das distribuidoras e permissionárias devem ser recuperáveis. Assim, sempre que forem identificados aspectos que indiquem alterações no valor de realização ou recuperação desses ativos e que se refiram a perdas permanentes, deverá ser constituída provisão para ajustar os respectivos saldos contábeis dos ativos aos seus reais valores de recuperação ou realização.

Esse registro, no entanto, deverá ser precedido de prévia anuência do órgão regulador sempre que o valor envolvido representar efeitos relevantes no conjunto das demonstrações contábeis da distribuidora ou permissionária.

Segundo o disposto na IC, a análise deverá estar embasada com o fluxo de caixa descontado, considerando o resultado global das operações da distribuidora ou permissionária. No caso específico do ativo imobilizado, entende-se por valor de recuperação o montante que as distribuidoras e permissionárias esperam recuperar pelo uso futuro de um ativo nas suas operações, incluindo seu valor residual na baixa.

Dessa forma, o valor de recuperação do imobilizado (um item ou grupo de itens) deve ser avaliado a cada exercício, com o objetivo de identificar eventuais necessidades de constituição da referida provisão. A análise da possibilidade de recuperação dos ativos deve levar em conta o grupo de itens do imobilizado que formam um conjunto ou projeto e os demais ativos correspondentes.

Segundo essa instrução contábil, a avaliação do valor de recuperação ou realização dos demais ativos deverá ser procedida pelo menos a cada 4 (quatro) anos, sendo a primeira no 
exercício de 2002 caso ainda não tenha sido efetuada pela administração (MCSPEE, 2001, p. $51)$.

No caso de um eventual aumento subsequente no valor de recuperação desses ativos, as provisões anteriormente efetuadas devem ser ajustadas. As evidências que suportaram as respectivas análises, incluindo as decisões, deverão ficar à disposição do órgão regulador, podendo ser requisitadas em eventuais processos de fiscalização ou a qualquer momento julgado necessário.

\subsubsection{Plano de Contas}

O Plano de Contas apresenta o elenco de contas propriamente dito, o grupo ao qual a conta pertence, o título da conta, sua função e técnica de funcionamento. Esse elenco abrange uma quantidade de 229 contas contábeis. Veja o exemplo abaixo:

Figura 1 - Exemplo de uma conta contábil do plano de contas

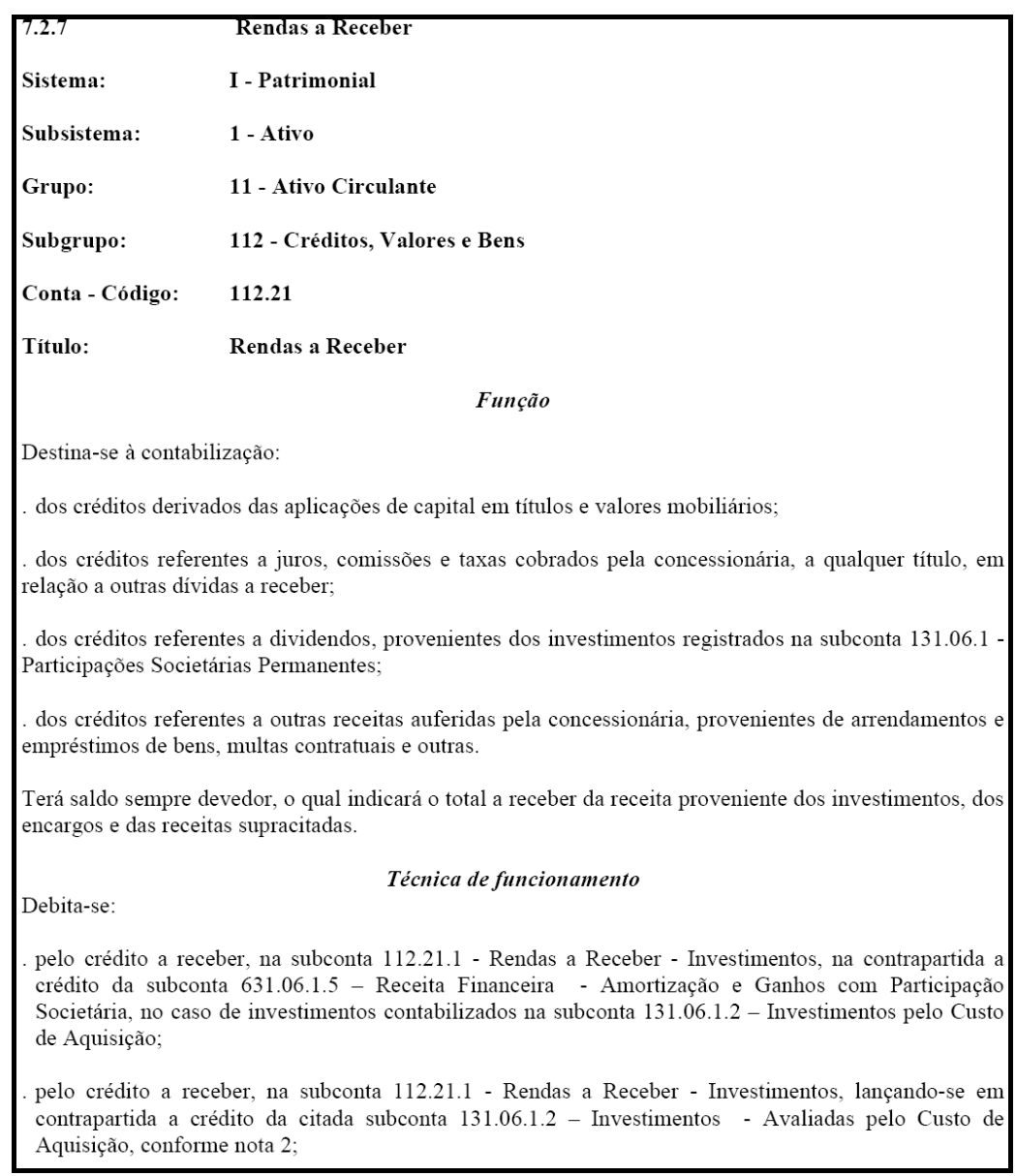

Fonte: MCSPEE, 2001, p. 159. 
Pela figura nota-se que o elenco de contas fornece o que deve conter a conta contábil e até o que deve ser creditado e debitado, de forma que ao receber um balancete o regulador entenda claramente o que está sendo demonstrado, reduzindo assim a assimetria de informação.

Quanto ao roteiro para elaboração e divulgação de informações contábeis, o Manual contém as orientações gerais sobre a forma de apresentação e datas de publicação.

Quanto à forma das demonstrações, o Manual apresenta modelos de relatório de administração, balanço patrimonial, demonstração do resultado, demonstração das mutações do patrimônio líquido, demonstração das origens e aplicação dos recursos, que seguem o modelo societário vigente.

Já os demonstrativos complementares, tais como o balanço social, demonstração do fluxo de caixa, demonstração do valor adicionado, que até então não eram obrigatórios pela legislação societária seguem um modelo desenhado pela própria Aneel.

Observam-se aspectos relativos à padronização das demonstrações contábeis, sua evidenciação e enquadramento das atividades relacionadas à concessão, além de instruções específicas de formas e naturezas de contas contábeis quando da leitura do Manual. Contudo, os principais aspectos a serem verificados são a busca de controle total do sistema contábil patrimonial e a padronização para que haja total compreensão das demonstrações financeiras publicadas.

Nota-se que para atender aos preceitos legais que estabelecem as funções regulatórias, a contabilidade, por meio do MCSPEE, é instrumento de geração de informações indispensáveis à regulação.

Ainda pelo detalhamento e complexidade das informações processadas, a contabilidade regulatória visa detectar comportamentos anti-competitivos, contribuir no esclarecimento de custos incorridos, auxiliar na comparação entre empresas que atuam no mesmo mercado, participar como instrumento nas revisões tarifárias, além de gerar informações de natureza econômica, financeira, física e de produtividade, entre outras (MCSPEE, 2001, p. 12).

Adicionalmente deve-se atentar que, para a eficácia da atividade regulatória, é fundamental que se tenha a competência e que se obtenham os instrumentos necessários para fazer cumprir o estabelecido nos normativos. Entretanto, não haverá eficácia se a agência reguladora não detiver condições e instrumentos adequados para o desempenho de suas funções ou não possuir poderes para este exercício (CORREA ET ALLI, 2006). 
Assim sendo, a contabilidade regulatória, estabelecida pela Resolução Aneel 444/2001, torna-se mecanismo para que o regulador exerça sua função, contribuindo sobremaneira no monitoramento e controle da atividade concedida.

\subsubsection{Aspectos distintivos entre a Contabilidade Regulatória e a Contabilidade Societária}

Neste tópico são apresentados aspectos da contabilidade regulatória que a distinguem da contabilidade societária, além de dois casos específicos em que o tratamento dado pela contabilidade regulatória demonstra sua função de complementariedade à contabilidade societária.

\subsubsection{Publicação de demonstrativos}

Com a publicação da Lei $\mathrm{n}^{0}$ 11.638/2007 foi normatizado que ao fim de cada exercício social a sociedade anônima deverá elaborar com base em sua escrituração mercantil as seguintes demonstrações financeiras, que deverão exprimir com clareza a situação do patrimônio da companhia e as mutações ocorridas no exercício:
a) balanço patrimonial;
b) demonstração dos lucros ou prejuízos acumulados;
c) demonstração do resultado do exercício;
d) demonstração dos fluxos de caixa;
e) se companhia aberta, demonstração do valor adicionado.

Os demonstrativos financeiros das distribuidoras e permissionárias do serviço público de energia elétrica que deverão ser enviados à Aneel, segundo o MCSPEE e a Resolução Aneel $n^{0}$ 64/1998, além daqueles exigidos pela legislação societária, quando aplicáveis, são os indicados abaixo e compõem a Prestação Anual de Contas - PAC:
a) composição do capital social;
b) balanço social;
c) relatório do conselho de administração;
d) parecer do auditor independente sobre as demonstrações contábeis;
e) relatório de recomendações dos auditores independentes para aprimoramento dos controles internos;


f) parecer dos auditores independentes sobre as mutações do ativo imobilizado;

g) parecer do conselho fiscal;

h) demonstrações contábeis de empreendimentos em condomínios e consórcios em função do serviço concedido.

Antes da obrigatoriedade trazida pela legislação societária, a Aneel já exigia a elaboração da DFC e da DVA e continua ainda na vanguarda no que se refere ao balanço social $^{17}$.

Cabe ressaltar que, segundo a Instrução Geral $\mathrm{n}^{\mathrm{o}} 5$ do MCSPEE, além desses demonstrativos do final do exercício, as empresas reguladas são obrigadas a elaborar e enviar para a Aneel, mensalmente, o Balanço Mensal Padronizado - BMP, e trimestralmente, o Relatório de Informações Trimestrais - RIT.

Os demonstrativos BMP e RIT referem-se à análise do investimento no serviço concedido, cálculo do capital de giro e do estoque, demonstrativo dos benefícios a empregados, demonstrativo das contas a receber e a pagar, demonstrativo do cálculo da reserva global de reversão, composição acionária, demonstração das mutações do ativo imobilizado - distribuição, administração e comercialização, fluxo de caixa trimestral e notas explicativas.

Esses demonstrativos servem como base de cálculo de dois encargos que são incluídos na tarifa, a Taxa de Fiscalização dos Serviços de Energia Elétrica ${ }^{18}$ e a Reserva Global de Reversão ${ }^{19}$.

Quanto à escrituração e estrutura dos grandes grupos de contas contábeis formadores dos demonstrativos, tais como balanço patrimonial e DRE, não se encontram diferenças entre o que preceitua a contabilidade societária e a regulatória. Contudo, considerando o objetivo maior de manutenção do equilíbrio econômico-financeiro previsto nos contratos de concessão, a contabilidade regulatória vem suprir lacunas da societária ou, até mesmo, substituir procedimentos visando adequar os procedimentos a situações específicas.

A seguir são apresentados dois exemplos da afirmação acima: reestruturação societária e segregação contábil das atividades.

\footnotetext{
${ }^{17}$ O Manual estabelece que o modelo a ser adotado é o proposto pelo Instituto Brasileiro de Análises Sociais e Econômicas - IBASE.

${ }^{18}$ A taxa de fiscalização de serviços de energia elétrica - TFSEE foi criada pela Lei n⿳0 9.427/1996 e foi instituída com vistas a constituir a receita da ANEEL para cobertura das suas despesas administrativas e operacionais. É fixada anualmente pela ANEEL e paga mensalmente, em duodécimos, por todos os agentes que atuam na geração, transmissão e distribuição de energia elétrica.

${ }^{19}$ A Reserva Global de Reversão - RGR - foi criada pela Lei nº 5.655, de 1971, com a finalidade de prover recursos para reversão, encampação, expansão e melhoria dos serviços públicos de energia elétrica.
} 


\subsubsection{Reestruturação societária visando à incorporação de ágio}

Costa (2006) fez a análise da evolução dos indicadores financeiros nas distribuidoras de energia elétrica pertencentes a um mesmo grupo econômico para identificar padrões comuns de gestão da dívida, utilizando como fonte de dados as demonstrações contábeis e as notas explicativas das distribuidoras.

Segundo a autora o que ocorria era a incorporação da controladora por sua controlada, esta geralmente uma Sociedade de Propósito Específico - SPE, com o intuito de utilizar na distribuidora o benefício fiscal do ágio pago na privatização, com impacto direto em seu resultado.

Conforme mencionado por Iudícibus, Martins e Gelbcke (2007, p. 534) "o conceito de ágio ou deságio aqui, não é a diferença entre o valor pago pelas ações a seu valor nominal, mas a diferença entre o valor pago e o valor patrimonial da ações, e ocorre quando adotado pelo método da equivalência patrimonial".

O inciso III do art. 7 da Lei 9.532, de 10/12/1997 dispõe que o tratamento tributário do ágio, cujo fundamento é a rentabilidade futura, dá a pessoa jurídica que absorveu o patrimônio da outra (em virtude da incorporação, na qual detenha participação societária adquirida com ágio ou deságio) o direito de amortizar o valor do ágio em até 10 anos subsequentes à incorporação, à razão de 1/60, no máximo, para cada período de apuração.

Segundo a autora, a Aneel verificou que muitas distribuidoras passaram a promover a incorporação de suas controladoras e do ágio gerado na aquisição da concessão e que sua amortização no prazo de dez anos vinha reduzindo em muito o resultado dessas empresas, demonstrando situação econômica diversa da realidade, onde não se observava o equilíbrio econômico-financeiro previsto no contrato de concessão.

O regulador passou, então, a definir a amortização do ágio para prazo idêntico ao remanescente da concessão, com uma curva de amortização não linear estabelecida de acordo com a projeção de apuração dos resultados no período da concessão, uma vez que entendeu que o prazo da concessão (normalmente 30 anos) foi elemento fundamental para calibrar o ágio que o investidor se dispôs a pagar nos leilões de compra do controle acionário.

A Aneel argumentou que o serviço público de energia elétrica tem várias características que o diferem de outros segmentos empresariais, pois há uma garantia legal do equilíbrio econômico-financeiro da concessão. A fim de se buscar esse equilíbrio, as receitas das distribuidoras são reguladas, definidas e fiscalizadas pelo poder concedente. Assim sendo, 
não seria razoável imaginar rentabilidade em níveis suficientes para amortizar ágios elevados em um terço do prazo de concessão (COSTA, 2006).

A problemática apresentada pela autora também é citada por Iudícibus, Martins e Gelbcke (2007, p. 230) sobre a mensuração de intangíveis:

No Brasil, independente da natureza do intangível, quer tenha vida útil limitada e definida, quer tenha vida útil indefinida, sua mensuração está limitada à abordagem da amortização. Com amparo no Arcabouço Contábil Conceitual em vigor, o registro contábil dos intangíveis é limitado à capacidade de estes gerarem benefícios econômicos.

Sequencialmente esses autores apresentam que para fins societários, nos termos da Instrução CVM 247/96, o ágio, conforme sua fundamentação econômica, deve ser amortizado:

a) em consonância com a vida útil remanescente do ativo que lhe originou, se este for o fundamento, em 10 anos;

b) se for justificado por lucros esperados, ou se advindo de uma concessão governamental onerosa, deve sê-lo no prazo máximo contratual, conforme contrato de concessão celebrado com o ente público.

Em termos de cotas de amortização, para as distribuidoras de energia elétrica, a Aneel fixa a curva a ser adotada (IUDÍCIBUS, MARTINS E GELBCKE, 2007).

Dessa forma, esse exemplo demonstra o estabelecimento de procedimentos contábeis específicos instituídos pela contabilidade regulatória, onde o regulador agiu de forma contundente em relação a amortização do ágio, definindo sua curva e não deixando margem para que a distribuidora usasse do benefício em detrimento do resultado das demonstrações financeiras.

Tal fato reforça ainda que o regulador busca conduzir o processo de divulgação das informações relativas à concessão de forma que estas evidenciem a realidade ocorrida, o que está alinhado ao objetivo buscado pela convergência das normas internacionais de contabilidade.

\subsubsection{Segregação contábil das atividades de geração, transmissão e distribuição e as sociedades de propósito específico}

Outro aspecto da contabilidade regulatória que merece destaque refere-se ao processo de reestruturação societária das empresas do setor, com a segregação de suas atividades. Para 
entender o processo é necessário retomar o ambiente de 1995, quando foram iniciadas as privatizações do setor.

Naquele momento as empresas eram integralmente verticalizadas, exercendo as atividades de geração, distribuição e transmissão de energia elétrica.

Segundo Pires e Goldstein (2001), empresas integralmente verticalizadas constituem uma ameaça à competição nos mercados em que atuam, principalmente quando fazem parte de indústria de rede, como é o caso do setor elétrico. Tal ameaça surge da possibilidade de que empresas nessas situações pratiquem subsídios cruzados, fazendo com que os consumidores do mercado em que atuam como monopolistas subsidiem as outras atividades inseridas no mercado competitivo, de modo que, neste mercado, essas empresas apresentem uma vantagem competitiva em termos de preços, o que lesa a concorrência.

Somente com a publicação da Lei 10.848/2004, que altera a Lei 9.074/1995, a segregação das atividades foi estabelecida, como segue:

\footnotetext{
$\S 5^{\circ}$ As distribuidoras, as permissionárias e as autorizadas de serviço público de distribuição de energia elétrica que atuem no Sistema Interligado Nacional - SIN não poderão desenvolver atividades:

I - de geração de energia elétrica;

II - de transmissão de energia elétrica;

III - de venda de energia a consumidores de que tratam os arts. 15 e 16 desta Lei, exceto às unidades consumidoras localizadas na área de concessão ou permissão da empresa distribuidora, sob as mesmas condições reguladas aplicáveis aos demais consumidores não abrangidos por aqueles artigos, inclusive tarifas e prazos;

IV - de participação em outras sociedades de forma direta ou indireta, ressalvado o disposto no art. 31, inciso VIII, da Lei $\mathrm{n}^{\circ}$ 8.987, de 13 de fevereiro de 1995, e nos respectivos contratos de concessão; ou

V - estranhas ao objeto da concessão, permissão ou autorização, exceto nos casos previstos em lei e nos respectivos contratos de concessão.
}

Durante o período de 1995 a 2004, as empresas que adquiriam as concessões as recebiam com as atividades de geração, distribuição e transmissão. Diante disso, foi necessário criar um mecanismo adicional que limitasse a possibilidade das distribuidoras que ainda detivessem ativos na geração de contratarem sua própria energia a preços que observassem uma estratégia empresarial em detrimento de um preço competitivo.

A Aneel, ciente do ambiente instalado, inseriu entre as alterações do Manual de Contabilidade de 2001 que as empresas escriturassem e contabilizem suas atividades de forma segregada, sendo este o único instrumento que a Aneel dispunha para controlar as estratégias das distribuidoras.

Somente a partir de 2004, com a publicação da Lei 10.848/2004, as empresas atuantes no setor estão concluindo o processo de segregação de atividades e formação de Sociedades 
de Propósito Específico - $\mathrm{SPE}^{20}$ para que o modelo de competição pretendido, embora com regras regulatórias já estabelecidas, seja alcançado.

Ressalta-se que a constituição de uma SPE é interessante para o Poder Público, sob o ponto de vista de controle, pois facilita a fiscalização principalmente no caso das concessões tendo em vista a complexidade das relações com as empresas distribuidoras.

A respeito da segregação de atividades, nota-se outro ponto de convergência da contabilidade brasileira com as normas internacionais de contabilidade. Conforme apresentam Rehbein e Gonçalves (2008, p. 294), a norma internacional IFRS $8^{21}$ - Segmentos Operacionais, que substituirá o IAS $14^{22}$ a partir de janeiro de 2009 , dispõe com base no princípio fundamental que as entidades devem divulgar informações capazes de permitir aos usuários das suas demonstrações financeiras avaliar a natureza e os efeitos financeiros das atividades do negócio nas quais estão envolvidas, assim como os ambientes econômicos onde operam.

De acordo com os autores, o resumo técnico sobre a IFRS 8, preparado pelo IASC, é a norma sobre segmentos operacionais que se aplica, entre outras, às empresas que tenham depositado, ou estejam em vias de depositar, suas demonstrações financeiras junto à uma comissão de valores mobiliários ou de outra organização reguladora.

A IFRS 8 demonstra como a entidade deve reportar informações sobre seus segmentos operacionais nas demonstrações financeiras anuais e também define os requisitos das respectivas divulgações sobre produtos e serviços, áreas geográficas e principais clientes.

Um segmento operacional é um componente de uma entidade que desenvolve atividades de negócio das quais obtém receitas e pelas quais incorre em gastos e cujos resultados operacionais são regularmente revistos pelo principal responsável pela tomada de decisões operacionais da entidade sobre a imputação de recursos ao segmento e pela avaliação do seu desempenho.

Pela legislação societária em vigor, as informações por segmento não são requeridas. Entretanto, em 2007, a CVM divulgou por meio do Ofício Circular CVM/SNC/SEP/01/2007

\footnotetext{
${ }^{20}$ Segundo Carvalho (2007), somente com a publicação da Lei 11.079/2004, que instituiu o regime das Parcerias Públicos-Privadas - (PPPs), veio a tona um instituto de nome Sociedade de Propósito Específico - SPE. Contudo, esse autor afirma que esse instituto já era subentendido pelo contexto jurídico, desde a publicação da Lei 9074/1995, posterior e complementar a Lei das Concessões (Lei 8.987/1995), a qual estabelece que no âmbito das operações de licitações, a constituição de um consórcio de natureza instrumental, ou seja, de um consórcio que servirá de meio para estabelecer contrato com terceiros (que, no caso, compreendem a Administração Pública), sendo que uma vez vencedor, o consórcio extinguir-se-á a fim de que se constitua, em seu lugar, uma Sociedade de Propósito Específico - SPE. Enfim, o consórcio vencedor será transformado numa sociedade personalizada e de objetivo determinado (CARVALHO, 2007).

${ }^{21}$ International Financial Reporting Standards - IFRS.

22 IAS - 14 - Reporting Financial Information by Segment.
} 
o incentivo à divulgação das informações por segmento, seguindo a norma internacional. Observa-se, portanto, que a contabilidade regulatória do setor elétrico já exigia essa segregação desde 2001, estando alinhada, portanto, aos preceitos internacionais.

Esses dois casos específicos demonstram a aplicação da contabilidade regulatória através dos demonstrativos financeiros, dissipando ou mitigando as estratégicas de maximização do lucro dos empreendedores atuantes no setor em detrimento do consumidor de energia elétrica, tornando-se importante mecanismo para o adequado funcionamento do modelo de regulação adotado.

A seguir são tratados os aspectos relacionados à convergência da contabilidade societária com os padrões internacionais de contabilidade, conforme disposto na lei 11.638/2007, bem como as interpretações que se referem aos contratos entre entes público e privados.

\subsection{CONTABILIDADE SOCIETÁRIA}

A atual legislação societária é regida pela Lei 6.404/76 que, segundo Iudícibus, Martins e Gelbcke (2007, p. 1), quando da sua publicação representou uma verdadeira revolução no campo contábil, determinando aprimoramento formidável a essa área no Brasil, introduzindo inclusive técnicas para as quais uma parcela substancial dos profissionais do setor não estava preparada.

Desde o início de sua vigência ocorreram diversos ajustes, com destaque para os decorrentes da promulgação da Constituição Federal do Brasil em 1988, tempos de altas taxas inflacionárias, quando se aplicava a correção integral das demonstrações contábeis, e anos depois, em 1994, com o Plano Real, que mudou o cenário econômico do país.

Em 2007, a legislação societária sofreu significativa alteração decorrente da publicação da Lei 11.638/2007, que alterou e revogou alguns dispositivos da Lei 6.404/1976, e da Medida Provisória 449/2008, que altera a legislação tributária federal relativa ao parcelamento ordinário de débitos tributários, concede remissão nos casos em que especifica e institui regime tributário de transição.

Importante destacar que o projeto de lei que deu origem à Lei 11.638 ficou em tramitação durante sete anos. Segundo Martins, Martins e Martins (2007): “em 2000 um

projeto de lei, de $n^{0} 3.741 / 2000,[.$.$] após sete anos de discussão, parece que está,$ efetivamente, para ser votado. E ele poderá, realmente, significar um outro fantástico ponto de apoio para nossa evolução contábil”. 
Pode-se, novamente, parafrasear Iudícibus, Martins e Gelbcke (2007) no sentido de que as alterações trazidas pela Lei em questão, guardadas as devidas proporções, representam um outro momento histórico do aprimoramento da área contábil.

\subsubsection{Um novo modelo para a contabilidade societária}

As mudanças trazidas pela Lei $11.638 / 2007$ e pela Medida Provisória 449/2008 ${ }^{23}$ têm como um de seus objetivos que as normas contábeis deverão ser elaboradas em consonância com os padrões internacionais de contabilidade adotados nos principais mercados de valores mobiliários - art. $177, \S 5^{\text {o: }}$

Art. 177. A escrituração da companhia será mantida em registros permanentes, com obediência aos preceitos da legislação comercial e desta Lei e aos princípios de contabilidade geralmente aceitos, devendo observar métodos ou critérios contábeis uniformes no tempo e registrar as mutações patrimoniais segundo o regime de competência.

[...]

$\S 50$ As normas expedidas pela Comissão de Valores Mobiliários a que se refere o $\S$ 3o deste artigo deverão ser elaboradas em consonância com os padrões internacionais de contabilidade adotados nos principais mercados de valores mobiliários.

Por padrões internacionais de contabilidade entende-se como a normatização emitida pelo International Accounting Standards Board - IASB. O IASB iniciou suas atividades em 2001, substituindo o antigo International Accounting Standards Committee - IASC.

Segundo o CFC e o IBRACON (2006, p. 3), o International Financial Reporting Interpretations Committee - IFRIC, é o comitê de interpretações ligado ao IASB que emite as interpretações técnicas oficiais. Na época do antigo IASC também havia um comitê de interpretações denominado Standing Interpretations Committee - SIC, que desempenhava funções semelhantes às do atual IFRIC. O SIC emitiu durante sua existência 33 interpretações. Muitas delas foram incorporadas pelo IASB quando da revisão e da atualização daquelas normas.

O conjunto de normas e interpretações composto por IFRS, IAS, IFRIC e SIC forma o que se conhece por normas internacionais de contabilidade, ou International Financial Reporting Standards (IBRACOM, 2006, p. 4).

O IASB, segundo Martins, Martins e Martins (2007), tem como grandes usuários gerais o investidor minoritário e o credor, com leve preponderância do primeiro, mas também

\footnotetext{
${ }^{23}$ O Governo Federal editou a Medida Provisória 449 que, nos termos de sua exposição de motivos, tem por objetivo "neutralizar os impactos dos novos métodos e critérios contábeis introduzidos pela Lei 11.638, de 28 de dezembro de 2007 , na apuração das bases de cálculos de tributos federais", removendo assim a insegurança jurídica causada aos contribuintes com a edição da referida lei.
} 
se preocupa com empregados e outros usuários; de forma alguma tem como objetivo quaisquer usuários em particular, como o fisco, órgãos reguladores etc.

No sentido do direcionamento da harmonização contábil brasileira com padrões internacionais, ressalta-se a criação do Comitê de Pronunciamentos Contábeis - CPC, em 2005, pela Resolução do Conselho Federal de Contabilidade n $1.055 / 05$. O CPC tem como objetivo:

O estudo, o preparo e a emissão de Pronunciamentos Técnicos sobre procedimentos de Contabilidade e a divulgação de informações dessa natureza, para permitir a emissão de normas pela entidade reguladora brasileira, visando à centralização e uniformização do seu processo de produção, levando sempre em conta a convergência da Contabilidade Brasileira aos padrões internacionais (CPC, 2007, p. 12).

Segundo o CPC (2007, p. 4), em uma perspectiva da história, foi a abertura da economia brasileira para o exterior que colocou as empresas brasileiras em contato direto com economias mais avançadas, inclusive com títulos negociados nas bolsas de maior movimento do mundo, e ao alcance dos investidores sediados em outros países. Como consequência, ficou muito claro que a diversidade de práticas contábeis entre as diversas economias representava um significativo custo extra e uma dificuldade a mais para a indispensável troca de informações e para a acomodação de posições.

Isso, considera o CPC (2007), não ocorreu apenas para as empresas brasileiras, mas também para algumas economias centrais, que pelas mesmas razões também buscam uma maneira de compatibilizar normas e procedimentos contábeis.

A harmonização das normas contábeis passou a fazer parte das preocupações de alguns organismos como o Conselho Federal de Contabilidade - CFC e a Comissão de Valores Mobiliários - CVM, que iniciaram um movimento para levar a contabilidade brasileira a seguir o caminho da internacionalização das suas normas. Esses fatos, juntamente com a criação do CPC, representam importantes avanços no caminho da modernização e atualização contábil tendo em vista a globalização da economia mundial.

O pronunciamento conceitual básico do CPC, aprovado pela Deliberação CVM noำ 539 , de 14/03/2008, denominado "Estrutura conceitual para a elaboração e apresentação das demonstrações contábeis" ${ }^{24}$ faz referência, em seu parágrafo 35 , à primazia da essência sob a forma, seguindo a mesma tendência internacional:

Para que a informação represente adequadamente as transações e outros eventos que ela se propõe a representar, é necessário que essas transações e eventos sejam

\footnotetext{
${ }^{24}$ Correlação às Normas Internacionais de Contabilidade - "Estrutura para a Preparação e a Apresentação das Demonstrações Contábeis" (Framework for the Preparation and Presentation of Financial Statements - IASB).
} 
contabilizados e apresentados de acordo com a sua substância e realidade econômica, e não meramente sua forma legal. A essência das transações ou outros eventos nem sempre é consistente com o que aparenta ser com base na sua forma legal ou artificialmente produzida. Por exemplo, uma entidade pode vender um ativo a um terceiro de tal maneira que a documentação indique a transferência legal da propriedade a esse terceiro; entretanto, poderão existir acordos que assegurem que a entidade continuará a usufruir os futuros benefícios econômicos gerados pelo ativo e o recomprará depois de um certo tempo por um montante que se aproxima do valor original de venda acrescido de juros de mercado durante esse período. Em tais circunstâncias, reportar a venda não representaria adequadamente a transação formalizada.

A esse respeito considera Iudícibus (1997, p. 76) que a prevalência da essência sobre a forma adquire tamanha importância que talvez devesse ser um Postulado ou um "Prérequisito" [..] e que "sempre que houver discrepância entre a forma jurídica de uma operação a ser contabilizada e sua essência econômica, a contabilidade deverá privilegiar a essência sobre a forma”. Isso significa que a contabilidade, em situações discrepantes, deverá priorizar a divulgação do fato observando os seus aspectos econômicos e não a forma jurídica.

Isto pode de ser justificado pelo fato de que a tomada de decisões econômicas com base nas informações dos demonstrativos é realizada com frequência. Conforme Iudícibus (1997, p. 20):

\begin{abstract}
Uma afirmação geral é que a função fundamental da contabilidade tem permanecido inalterada desde seus primórdios. Sua finalidade é prover aos usuários dos demonstrativos financeiros informações que os ajudarão a tomar decisões. Sem dúvida, tem havido mudanças substanciais nos tipos de usuários e formas de informação que têm procurado. Todavia, esta função dos demonstrativos financeiros é fundamental e profunda. O objetivo básico dos demonstrativos financeiros é prover informação útil para tomada de decisões econômicas [...].
\end{abstract}

Ainda acerca do objetivo acima, considera Iudícibus (1997, p. 21) que a decisão sobre o que é útil ou não para a tomada de decisões econômicas é muito difícil de ser avaliada na prática. Isto poderia exigir um estudo mais aprofundado do modelo decisório de cada tipo de tomador de decisões que se utiliza de dados contábeis.

Outros autores a serem citados sobre o objetivo da contabilidade são Hendriksen e Breda (1999, p. 282), os quais afirmam que:

A apresentação de um resumo dos recursos e das obrigações de uma empresa aos acionistas e outros investidores, a intervalos regulares, sob a forma de uma demonstração de posição financeira, é um dos principais objetivos da contabilidade.

A estrutura conceitual para a elaboração e a apresentação das demonstrações contábeis emitida pelo CPC cita, no parágrafo 9, quais são seus principais usuários e suas necessidades:

9. Entre os usuários das demonstrações contábeis incluem-se investidores atuais e potenciais, empregados, credores por empréstimos, fornecedores e outros credores comerciais, clientes, governos e suas agências e o público. Eles usam as 
demonstrações contábeis para satisfazer algumas das suas diversas necessidades de informação. Essas necessidades incluem:

[...]

(f) Governo e suas agências. Os governos e suas agências estão interessados na destinação de recursos e, portanto, nas atividades das entidades. Necessitam também de informações a fim de regulamentar as atividades das entidades, estabelecerem políticas fiscais e servir de base para determinar a renda nacional e estatísticas semelhantes.

Percebe-se que os usuários das demonstrações financeiras devem ser atendidos pela contabilidade em suas necessidades de informação, englobando-se deste modo também as agências reguladoras.

Um aspecto de grande relevância para o objetivo deste trabalho é mencionado por Iudícibus, Martins e Gelbcke (2007, p. 31), que afirmam que uma forma prática de verificar se a contabilidade está alcançando seus objetivos é pesquisar, periodicamente, qual o grau de utilização das demonstrações contábeis por parte de grupos de usuários para os quais, de antemão, se acredita que as demonstrações contábeis devem ser de grande utilidade.

Ainda segundo esses autores, o fato de determinado grupo utilizar-se num menor grau de intensidade de informação contábil do que imaginaríamos pode ter vários significados:

a) deficiências estruturais do modelo informativo-contábil para tal tipo de decisão;

b) restrições ou limitações do próprio usuário;

c) ambiente decisório em que a profissão contábil está laureado por baixo status de credibilidade, influenciando a não utilização por parte de alguns grupos;

d) falhas de comunicação e evidenciação decorrentes de problemas de linguagem inadequada por parte das demonstrações contábeis.

Sendo assim, a contabilidade está sempre procurando atender aos usuários com informações sobre a realidade econômico-financeira do seu objeto, o patrimônio, sob a forma de relatórios e demonstrações com a preocupação de que estes sejam de grande utilidade na tomada de decisão.

Considerando a alteração no modelo contábil, nota-se que haverá impactos na evidenciação da realidade econômica das empresas que estão sob o regime de concessão do setor elétrico brasileiro, uma vez que as regras de contabilização atualmente utilizadas diferem dos normativos internacionais, afetando, portanto, a tomada de decisão dos diversos usuários dessas informações, em especial o regulador e o investidor. 
Tendo em vista que o novo modelo da contabilidade societária tem como objetivo harmonizar os procedimentos nacionais aos internacionais, torna-se de grande relevância o conhecimento do modelo proposto pelos órgãos internacionais.

Apresenta-se a seguir dois normativos que tratam da contabilização das concessões de serviços públicos, cabendo ressaltar que o que se pretende analisar é a forma de contabilização dos contratos e sua contribuição para a contabilidade regulatória do setor elétrico, com foco no usuário regulador.

\subsubsection{Normas internacionais para concessões}

Conforme mencionado, o IASB emite as normas internacionais de contabilidade que são denominadas International Financial Reporting Standards - IFRS. Adicionalmente a essas normas existem interpretações que são publicadas pelo International Financial Reporting Interpretations Committee - IFRIC. Este é um comitê ligado ao IASB que emite as interpretações técnicas oficiais, para auxiliar na aplicação de uma norma em relação a um determinado assunto que esteja em evidência e que requeira direcionamento sobre sua correta interpretação técnica (CFC e IBRACON, 2007, p. 8). Assim as interpretações dos IFRS, são denominadas IFRIC.

No âmbito internacional, o documento que trata da contabilidade aplicável às concessões de serviços (arrangements concession service) pelo lado privado é a interpretação IFRIC 12 - Service Concession Arrangements, emitida pelo International Accounting Standards Board - IASB.

Um outro normativo é o Standing Interpretations Committee - $\mathrm{SIC}^{25} 29$ - Service Concession Arrangements: Disclosures, que trata exclusivamente da evidenciação de contratos de concessão. Este tópico apresenta a IFRIC 12, que trata da contabilização, considerando o objetivo deste trabalho onde busca-se uma análise de como esse tipo de contabilização possibilitaria a identificação do equilíbrio econômico-financeiro dos contratos de concessão.

É necessário esclarecer que esses documentos são importantes para a interpretação da forma de contabilização dos contratos celebrados entre concessor e operador pela qualidade da análise neles contida e não pelo seu efetivo poder normativo.

\footnotetext{
${ }^{25}$ Standing Interpretations Committee - SIC, é um comitê que desempenhava funções semelhantes às do atual IFRIC.
} 
O princípio que orienta os dois normativos é que os registros financeiros e contábeis devem refletir a essência econômica das transações.

Sobre o trabalho de convergência das normas, segundo Martins, Martins e Martins (2007), provavelmente na maioria das situações existirão apenas traduções de normas do IASB, em outras, quando forem necessários, ajustes serão efetuados de natureza talvez redacional, exemplificativa ou outra, sem que a substância se modifique. Em casos extremos é que poderá haver alguma não convergência, que deverá ser temporária, ou por razões de ordem legal ou outra a ser devidamente sanada.

Destaca-se o que apresenta esses autores, sobre a filosofia do IASB:

Procura trabalhar com base na filosofia do principles oriented, ou seja, suas normas procuram dar mais ênfase aos princípios do que às regras detalhadas, apesar de algumas vezes isso não ser bem seguido, principalmente em situações muito difíceis e novas, como no caso dos instrumentos financeiros avaliados a mercado. Segue a filosofia, é claro, da true and fair view e da representação econômica (MARTINS, MARTINS E MARTINS, 2007).

Um dos pontos mais relevantes defendido pelo IASB é que a essência prevalece sobre a forma a ponto de, em seu pronunciamento IAS 1, definir que no momento da aplicação de suas normas, se alguma delas em situação que se acredita seja rara produzir qualquer deformação em qualquer informação contábil, ela não poderá ser usada e terá que ser substituída por outra que retrate melhor o que precisa ser contabilizado. Caso contrário, não poderá a empresa dizer que está seguindo as normas internacionais, ou seja, a substância econômica é mais relevante do que as regras propriamente ditas (MARTINS, MARTINS E MARTINS, 2007).

\subsubsection{IFRIC 12 - Service Concession Arrangements}

A interpretação IFRIC 12 - Service Concession Arrangements é o normativo direcionado para contratos de concessões de serviços. Tem como objetivo orientar os operadores dos serviços de concessão na contabilização dos contratos celebrados, estabelecendo princípios gerais sobre o reconhecimento e mensuração dos ativos e passivos, receitas e despesas, decorrentes do contrato que envolve esse tipo de prestação de serviço.

A IFRIC 12 foi publicada no ano de 2006 e entrou efetivamente em vigor em 01/01/2008. Trata da contabilização dos contratos por parte do operador, celebrados entre as empresas (distribuidoras ou permissionárias) e o governo (poder concedente). Esses contratos geram fatos contábeis diversos, com efeitos econômicos que, se não reconhecidos e 
mensurados pela contabilidade, podem gerar uma representação patrimonial das partes envolvidas não verdadeira.

Esses contratos são muitas vezes descritos como build-operate-transfer (onde o empreendedor constrói, opera e transfere o bem ao poder concedente após determinado período), rehabilitate-operate-transfer ou 'public-to-private' service concession arrangement (contrato de serviço de concessão de PPP - Parceria Público-Privada).

A IFRIC 12 apresenta no background (parágrafo 2) que alguns países introduziram contratos de concessão dos serviços públicos, tais como, estradas, prisões, distribuição de água e distribuição de energia elétrica, entre outros, para atrair a participação do setor privado no desenvolvimento, financiando a operação e manutenção de tal infra-estrutura, podendo ser já existente ou a ser construída durante o período do contrato.

Ainda nesse parágrafo da IFRIC, afirma-se que a concessão é regida por um contrato que fixa parâmetros de desempenho, mecanismos de atualização de preços e normas para arbitrar disputas contratuais.

Segundo essa interpretação, esses contratos definem a obrigação por parte do operador de prestar o serviço aos usuários em nome da entidade do setor público e apresentam algumas características comuns: os contratos fixam os preços iniciais a serem arrecadados pelo operador e as revisões são reguladas ao longo do período do serviço; o operador é obrigado a entregar a infra-estrutura ao concedente em uma determinada condição no final do período do contrato (IFRIC 12, parágrafo 3).

O parágrafo 7 da IFRIC 12 apresenta a padronização dos contratos de concessão em dois tipos:

a) quando o operador (parceiro privado) constrói ou adquire ativos de terceiros com a finalidade de prestar serviços dispostos no contrato;

b) quando já existe a infra-estrutura à qual o concedente permite o acesso ao operador para prestar os serviços do contrato.

Em termos gerais, a IFRIC 12 apresenta orientação sobre os pontos:

a) tratamento dos direitos do operador sobre a infra-estrutura;

b) reconhecimento e mensuração do contrato considerado e tratamento contábil subsequente; e

c) construção ou atualização dos serviços e operação dos serviços. 
Sobre os pontos listados acima, apresenta-se a seguir o que dizem os parágrafos da interpretação:

\section{a) tratamento dos direitos do parceiro privado sobre a infra-estrutura}

Esse ponto é um dos destaques da norma em relação ao que é feito atualmente. Segundo o parágrafo 11, nenhuma infra-estrutura, construída ou não pelo operador, pode ser reconhecida como ativo permanente da distribuidora porque esta não detém o direito de controlar a infra-estrutura e sim o direito de operá-la, proporcionando o serviço público em nome do concedente e em consonância com os termos do contrato assinado.

Nesse tópico é necessário fazer algumas considerações a respeito do controle da infraestrutura por parte do concedente. Segundo o parágrafo 5 da IFRIC 12, a interpretação será aplicada aos contratos se:

a) o concedente controla ou regula quais os serviços que o operador deve fornecer com a infra-estrutura, a quem tem que fornecer e a que preço;

b) o concedente controla, por meio de propriedade ou direito de acesso aos benefícios ou outras formas, o interesse residual na propriedade ao fim do contrato.

A leitura desse parágrafo, em conjunto com o parágrafo 11, leva à interpretação de que se o operador não detém o controle da propriedade e sim o concedente, que também é quem tem os direitos aos benefícios residuais sobre a infra-estrutura no final do contrato, a este último é que caberia a escrituração do ativo.

\section{b) reconhecimento e mensuração do contrato e tratamento contábil subsequente}

No que se refere à escrituração do parceiro privado, considerando a natureza do fato econômico, o normativo internacional diz que o registro do direito deve ser reconhecido como um ativo financeiro ou como um ativo intangível.

Segundo o International Accounting Standards - IAS $32^{26}$, um ativo financeiro é qualquer ativo em dinheiro, um instrumento patrimonial de uma outra entidade ou um direito

\footnotetext{
26 IAS 32: um ativo financeiro é qualquer ativo que seja: (a) dinheiro; (b) um instrumento patrimonial de uma outra entidade; (c) um direito contratual: (i) de receber dinheiro ou outro ativo financeiro de outra entidade; ou (ii) de trocar ativos financeiros ou passivos financeiros com outra entidade em condições que sejam potencialmente favoráveis para a entidade; ou (d) um contrato que será ou poderá ser liquidado nos instrumentos patrimoniais da própria entidade e que seja: (i) um não derivativo para o qual a entidade esteja ou possa estar obrigada a receber um número variável dos instrumentos patrimoniais da própria entidade; ou (ii) um derivativo que será ou poderá ser liquidado de forma diferente da troca de uma quantia fixa em dinheiro ou outro ativo financeiro por um número fixo dos instrumentos de capital próprio da própria entidade. Para esta finalidade, os instrumentos patrimoniais da própria entidade, não incluem instrumentos que sejam eles próprios contratos para futuro recebimento ou entrega dos instrumentos patrimoniais da própria entidade.
} 
contratual. Nesse caso, o ativo será classificado como instrumento financeiro, pois este pode ser definido como qualquer contrato que resulta em um ativo financeiro de uma entidade e um passivo financeiro ou instrumento patrimonial de outra entidade, sendo o valor devido contabilizado como um empréstimo ou recebível, um ativo financeiro disponível para venda, ou se assim for designado no momento do reconhecimento inicial, um ativo financeiro pelo valor justo.

Sobre ativos intangíveis, a norma internacional que trata do tema é o IAS 38. Esta apresenta o tratamento contábil dos ativos intangíveis e traz sua definição como sendo um ativo não-monetário, identificável, sem substância física, utilizado na produção ou fornecimento de mercadorias ou serviços, para ser alugado a terceiros ou para fins administrativos. Não deve ser confundido com o goodwill (ágio pago por expectativa de rentabilidade futura). Um ativo intangível também pode ser gerado por direitos contratuais ou outros direitos legais, independentemente de tais direitos serem transferíveis ou separáveis da entidade ou de outros direitos e obrigações.

Segundo Iudícibus (1997, p. 203), uma das definições mais adequadas para ativos intangíveis é "ativos de capital que não têm existência física, cujo valor é limitado pelos direitos e benefícios que, antecipadamente, sua posse confere ao proprietário".

Outra definição pode ser encontrada em Schmidt e Santos (2002), onde é possível definir ativos intangíveis como recursos incorpóreos controlados pela empresa, capazes de produzir benefícios futuros.

Sobre reconhecimento e mensuração de ativos intangíveis, descreve o parágrafo 31 do IAS 38:

a) um adquirente reconhece um ativo intangível quando encontra os critérios de reconhecimento estabelecidos no parágrafo $19^{27}$ do IAS 38, mesmo que o ativo intangível não tenha sido reconhecido nas demonstrações financeiras;

b) se o valor justo de um ativo intangível adquirido como parte de uma combinação de negócios do tipo aquisição do controle acionário não puder ser mensurado confiavelmente, esse ativo não é reconhecido como ativo intangível separado, mas incluído no goodwill.

\footnotetext{
27 Segundo o parágrafo 19 do IAS 38, um ativo intangível deve ser reconhecido somente quando: a) são prováveis os benefícios econômicos futuros do ativo para entidade; b) o valor do ativo pode ser mensurado confiavelmente.
} 
O custo de um ativo intangível é avaliado pelo seu valor justo, a não ser que não tenha natureza comercial (quando tem expectativa de rentabilidade futura, ou seja, benefícios econômicos futuros) ou o seu valor justo não puder ser mensurado corretamente.

Sobre o fair value como valor de mensuração, apresenta-se a seguir a definição do International Accounting Standards - IASB e do Financial Accounting Standards Board FASB. O IASB apresenta nos pronunciamentos, IAS 2, IAS 17, IAS 18, IAS 21, IAS 32, IAS 39, IAS 41, IFRS 1, IFRS 3, IFRS 4 e IFRS 5, a seguinte definição do fair value: "Montante pelo qual um ativo poderia ser trocado, ou um passivo liquidado, entre partes interessadas, bem informadas e dispostas em uma transação entre partes não relacionadas" 28 .

No International Financial Reporting Standardas - IFRS 2, fair value é assim definido: " Montante pelo qual um ativo poderia ser trocado, um passivo liquidado, ou um instrumento patrimonial poderia ser trocada, entre partes interessadas, bem informadas e dispostas em uma transação entre partes não relacionadas" 29.

No Financial Accounting Standards Board - FASB, no Pronunciamento SFAS 157: Fair Value Measurements, emitido em 2006, consta uma definição única de fair value para fins de demonstrações financeiras. Esse documento apresenta como objetivo prover diretrizes para o uso do fair value a avaliação de ativos e passivos, estabelecendo uma definição e critérios de mensuração.

Segundo o SFAS, 157, o fair value seria o preço recebido na venda de um ativo ou pago na transferência de um passivo, em uma transação ordenada, entre participantes do mercado, na data de mensuração.

Pela leitura das definições apresentadas percebe-se duas diferenças: a definição do SFAS no 157 é explicitamente um preço de saída, um preço de venda e o IASB não se refere explicitamente nem a preços de saída, nem a preços de entrada; o SFAS se refere explicitamente a participantes de mercado e o IASB se refere a partes interessadas, bem informadas e dispostas em uma transação entre partes não relacionadas.

Segundo um estudo elaborado pela Ernest \& Young - Auditores Independentes ${ }^{30}$, em 2008, sobre as diferenças e similaridades entre as Normas Internacionais de Contabilidade IFRS e as Normas e Práticas Contábeis Brasileiras, quanto ao tema Fair Value Measurement,

\footnotetext{
28 "the amount for which an asset could be exchanged, or a liability settled, between knowledgeable, willing parties in an arm's length transaction" (tradução livre).

29 "is the amount for which an asset could be exchanged, a liability settled, or an equity instrument granted could be exchanged, between knowledgeable, willing parties in an arm's length transaction" (tradução livre).

${ }^{30}$ Todos os documentos produzidos no âmbito desse trabalho sobre as diferenças e similaridades entre as práticas contábeis brasileiras e os IFRS, todo o material técnico desenvolvido, foi revisado detalhadamente por um corpo de professores-doutores da FIPECAFI, visando enriquecê-lo com a visão do catedrático.
} 
apesar de o processo para se estimar o fair value parecer complexo, existem 3 abordagens básicas de cálculo do 'valor justo' para fins de demonstrações financeiras:

1. Abordagem de mercado;

2. Abordagem da receita ou do lucro futuro;

3. Abordagem do custo.

Esse documento discute a abordagem de mercado, como sendo a que utiliza preços observáveis e outras informações relevantes geradas por transações de mercado que envolvem ativos ou passivos comparáveis, tendo como principais fontes dos valores de mercado: bolsas de valores, mercados de atacado e serviços de cotações.

Para a abordagem da receita ou do lucro futuro, o fair value poderia ser estimado baseado nos lucros futuros estimados e descontados a valor presente, com base em uma taxa de juros ajustada ao risco da empresa.

Interessante para o tema deste trabalho é a apresentação da abordagem do custo, onde o fair value seria baseado no valor que seria atualmente necessário para repor a capacidade de serviço do ativo em uso, considerando-se sua utilidade e obsolescência. Este método é conhecido como custo de reposição. A abordagem do custo é geralmente utilizada para estimar o valor de ativos como máquinas e equipamentos. Esta abordagem é uma variante da abordagem de mercado, olhando-se o lado do adquirente (entry price).

Em Ernest \& Young (2008) o desenvolvimento mais importante do SFAS 157 relacionado à mensuração do fair value é a introdução de um modelo baseado na hierarquia das premissas adotadas, esta hierarquia não se confunde com as técnicas de avaliação utilizadas, mas é utilizada para definir as premissas a serem utilizadas, que podem ser de fontes externas do mercado, e por isso observáveis, ou de fontes internas da empresa, as quais não são observáveis. A seleção de técnicas de avaliação será influenciada pela existência e disponibilidade de dados observáveis relevantes para os ativos ou passivos que são objeto da avaliação.

Os três níveis de hierarquia dos dados utilizados para as mensurações de fair value, de acordo com o SFAS 157, são:

- Nível 1 - Cotações de mercado: preços não ajustados de mercado de ativos ou passivos idênticos aos objetos da avaliação, que a empresa tenha acesso às informações na data da mensuração;

- Nível 2 - dados outros que não sejam cotações de mercado, mas que sejam observáveis de forma direta ou indireta; e 
- Nível 3 - Dados não observáveis: geralmente dados internos da própria empresa.

Os autores discutem que, na prática, a hierarquia obriga ao uso de informações do mercado, definido como mercado o principal mercado em que a empresa negociaria o item objeto da avaliação, o que significa que, diante da existência de um mercado, a avaliação não poderá utilizar dados internos da empresa na mensuração.

No entanto, diante da inexistência ou falta de liquidez do mercado principal, passa-se a utilizar outros mercados; neste caso, o mais vantajoso (aquele que maximiza o valor que seria recebido por um ativo e minimiza o valor que seria pago por um passivo) e somente diante da inexistência de um mercado ativo os demais níveis hierárquicos seriam utilizados, com o objetivo de maximizar o uso de informações de fontes externas e independentes da empresa (ERNEST \& YOUNG, 2008).

A discussão apresentada sobre as abordagens em conjunto com o nível de hierarquia apresentado pelo SFAS 157 permite inferir que dado a inexistência de um mercado onde o ativo pode ser transacionado poderia ser adotado o próximo nível, o nível 2, que envolve a utilização de dados outros que não sejam cotações de mercado, mas que sejam observáveis de forma direta ou indireta, nesta última opção poderia ser utilizada a abordagem de custo como sendo a opção de dados observáveis de forma direta e nesse caso o custo de reposição, quando observa-se que é a abordagem geralmente utilizada para estimar o valor de ativos como máquinas e equipamentos.

Isso é reforçado pelo que diz Lally (2002), a respeito da abordagem de mercado, no caso da avaliação de ativos de contratos de concessão de prestação de serviço público, é tema polêmico. Como se apresenta em um ambiente regulado, o valor de mercado dos ativos depende em parte das expectativas dos investidores sobre as restrições de preço e receita impostas pela regulação, assim como das sinergias potenciais que podem decorrer da transação. Em alguns casos os compradores podem estar exageradamente otimistas sobre os ganhos potenciais de uma transação, resultando em uma disposição a pagar preços "muito altos".

Nesse sentido argumentam Bragança e Camacho (2007) que estabelecer avaliações com base em valores de mercado é problemático para um monopólio. Dado que o valor de mercado depende em parte das expectativas sobre restrições regulatórias, um enfoque de transação de mercado tende a ser circular, isto é, o valor inclui os ganhos extraordinários de um monopólio. Além disso, segundo Lally (2002), se os investidores superavaliarem a transação e pagarem "muito" pelo ativo, obrigariam os consumidores a pagarem preços 
baseados no valor de aquisição, resultando em uma transferência líquida de riqueza dos consumidores correntes e futuros para os donos anteriores dos ativos.

Assim, considerando as hierarquias apresentadas pelo SFAS 157, poderíamos utilizar o nível 2, Ou seja, não podendo ser aplicado o nível 1 da hierarquia, passa-se ao nível 2, que envolve a utilização de dados outros que não sejam cotações de mercado, mas que sejam observáveis de forma direta ou indireta, utilizando o custo de reposição.

A discussão ganha sentido com o que apresenta o parágrafo 33 do IAS 16 - Ativos Tangíveis: se não houver provas com base no mercado do valor justo devido à natureza especializada do item do ativo tangível e se o item for raramente vendido, exceto como parte de um negócio em continuação, uma entidade pode estimar o fair value usando uma abordagem pelo rendimento ou pelo custo de reposição depreciado.

A discussão apresentada sobre fair value visa caracterizar as possíveis formas de se avaliar um ativo, e ainda evidenciar que tanto as definições como a forma de mensuração apresentadas pelos organismos internacionais que abordam o tema de forma mais direta, deixam claro que o ambiente de mensuração (mercado) e as características do ativo em si pesam mais no momento de se decidir em usar esta ou aquela abordagem.

Cabe ressaltar a conclusão apresentada no estudo da Ernest \& Young (2008), onde a relevância do fair value deveria ser testada com base nos objetivos do processo de elaboração das demonstrações financeiras, que incluem a utilidade para fins da tomada de decisão por meio de previsão de valores, época e incerteza dos futuros fluxos de entrada e saída de caixa.

Assim sendo, ao refletir sobre a aplicação do fair value nos ativos adquiridos nos contratos de concessão, considera-se como possibilidade o nível de hierarquia 2, dados outros que não sejam cotações de mercado, mas que sejam observáveis de forma direta ou indireta, e a abordagem do custo (custo de reposição).

Cabe ressaltar ainda que mesmo que a definição do que venha a ser valor justo não esteja objetivamente definida, só a introdução do conceito de fair value pela lei 11.638/2007, para a mensuração de ativos, apresenta para a contabilidade tradicional uma realidade nova e mais aderente com a evidenciação da situação patrimonial das empresas, em comparação com o tradicional custo histórico, trazendo perspectivas interessantes sobre os possíveis métodos de se apurar esse valor.

Por fim, considerando o objetivo deste trabalho, apresenta-se a seguir o que esclarecem Hendriksen e Breda (1999, p. 309) sobre o termo valor justo: "o termo valor justo tem sido usado principalmente no setor de serviços de utilidade pública em referência ao capital total sobre o qual os investidores têm direito de obter um retorno justo. Os tribunais 
têm julgado que o cálculo do valor justo deve incluir todos os fatos pertinentes, incluindo os custos passados prudentes e os custos de reprodução". Esses autores ressaltam que as empresas distribuidoras têm argumentado que deveria incluir principalmente os custos reposição. Segundo os autores, o valor justo não é uma base específica de avaliação que possa ser aplicada de maneira generalizada às demonstrações financeiras e concluem que, na verdade, trata-se de uma combinação de bases de avaliação determinadas pelas comissões e pelos tribunais para uma finalidade específica.

Dessa forma, em função das características dos ativos das distribuidoras de energia elétrica e em função do ambiente regulado, este trabalho adotará o custo de reposição como melhor estimativa de fair value.

Voltando a descrição da IFRIC 12, sobre a forma de reconhecimento dos ativos intangíveis, a interpretação remete ao IAS 38. Um ativo intangível deve ser reconhecido somente quando, parágrafo 19:

a) são prováveis os benefícios econômicos futuros do ativo para a entidade;

b) o valor do ativo pode ser mensurado confiavelmente.

De acordo com o parágrafo 16, o operador deve reconhecer um ativo financeiro na medida em que tem um direito contratual incondicional pela construção ou operação do serviço, tanto em dinheiro ou outro ativo financeiro. Aponta que, nessa situação, o concessor tem pouco ou talvez nenhum poder discricionário para evitar o pagamento, normalmente porque o contrato é exequível por lei. Dessa forma, nesse tratamento contábil para o ativo econômico é incondicional a obtenção dos fluxos futuros de caixa.

Se o operador presta mais que um serviço (por exemplo: construção e operação) em um único contrato, deverá segregar as receitas em prestação de serviços e construção. A referência dos recebíveis deve ser feita a fair value referentes aos serviços entregues.

Conforme Martins e Andrade (2008), a substância econômica desse ativo implica no reconhecimento de um ativo financeiro semelhante a um "contas a receber" decorrente de faturamento. Nota-se que, contratualmente, esse direito incondicional de recebimento de caixa futuro é constituído em função das atividades desempenhadas pelo parceiro privado, que podem ser da construção da infra-estrutura e/ou da operação da infra-estrutura (construída e/ou já existente).

Segundo o parágrafo 17 da IFRIC, o operador deverá reconhecer um ativo intangível à medida que recebe um direito (uma licença) de cobrar dos usuários do serviço público. Um 
direito para cobrar dos usuários do serviço público não é um direito incondicional para receber dinheiro porque os montantes estão condicionados à prestação do serviço público.

Nesse caso, diferente da classificação como ativo financeiro, o direito de cobrança não enseja em fluxos de caixa futuros incondicionais e determináveis. Eles carregam na sua natureza em função de riscos de demanda alto grau de incerteza, consequentemente, essa licença de cobrar tarifa não se caracteriza como um direito incondicional de receber um ativo financeiro, pois os montantes a serem recebidos estão subordinados à prestação do serviço.

Disso depreende-se que os fluxos de caixa futuros são incertos. Assim sendo, à medida que o operador realiza suas obrigações contratuais (construção e/ou operação do serviço), ele está adquirindo um direito de poder cobrar dos usuários; ou seja, o direito, derivado do cumprimento das obrigações contratuais, garante o acesso ao fluxo de caixa futuro.

Contudo, a execução da cobrança dos usuários do serviço representa um fluxo de caixa futuro incerto, variável e dependente de diversos fatores condicionantes tal como volatilidade da demanda. A contabilização desse fato econômico dá-se pelo reconhecimento contábil desse direito, que em sua natureza é algo intangível. Portanto, o ativo nesses casos contratuais consubstancia-se em um ativo intangível do parceiro privado.

\section{c) construção ou atualização dos serviços e operação dos serviços}

De acordo com o parágrafo 18 da IFRIC, se o operador é pago para a construção da infra-estrutura em parte por um ativo financeiro e em parte por um ativo intangível, é necessário contabilizar separadamente cada um desses componentes, observando ainda o seu valor justo.

Sobre a construção ou atualização da infra-estrutura e a operação dos serviços, o parágrafo 14 da IFRIC 12 dispõe que o operador deve reconhecer e mensurar as receitas e custos de acordo com a norma internacional IAS $11^{31}$ (contratos de construção), parágrafo 20, quando relacionados com a construção ou melhoria da infra-estrutura, e pela norma internacional IAS $18^{32}$ (receitas) quando da prestação de serviços.

\footnotetext{
${ }^{31}$ Segundo IAS 11, o crédito do contrato deve compreender: (a) a quantia inicial de crédito acordada no contrato; e (b) variações no trabalho, reclamações e pagamentos de incentivos do contrato: (i) até ao ponto que seja provável que resultem em crédito; e (ii) estejam em condições de serem confiavelmente mensurados. O crédito do contrato é medido pelo justo valor da retribuição recebida ou a receber

${ }^{32}$ Segundo IAS 18, Prestação de serviços, quando o desfecho de uma transação que envolva a prestação de serviços possa ser estimado com confiabilidade, o crédito associado com a transação deve ser reconhecido com referência à fase de acabamento da transação à data do balanço. O desfecho de uma transação pode ser estimado com confiabilidade quando todas as condições seguintes forem satisfeitas: (a) a quantia de crédito possa ser confiavelmente mensurada; (b) seja provável que os benefícios econômicos associados à transação fluam para a entidade; (c) a fase de acabamento da transação à data do balanço possa ser confiavelmente mensurada; e (d) os custos incorridos com a transação e os custos para concluir a transação possam ser confiavelmente mensurados.
} 
No que se refere às obrigações para manter a infra-estrutura em um nível específico de uso ou para restaurá-la a uma determinada condição antes de devolvê-la ao concedente ao final do contrato, com exceção de qualquer elemento de melhoria ou inovação, devem ser contabilizadas em conformidade com a norma internacional IAS 37 - Provisões, Passivos Contingentes e Ativos Contingentes, ou seja, na melhor estimativa da despesa que seria necessária para resolver a obrigação presente na data do balanço.

Alguns pontos apresentados pela IFRIC 12 merecem destaque como a classificação dos ativos que não é excludente, ou seja, pode haver contratos que apresentem ao mesmo tempo ativos financeiros e intangíveis. Outro ponto se refere à incerteza da geração de fluxos de caixa, sendo que no caso do ativo financeiro observa-se baixo risco, no entanto, no caso do ativo intangível o risco apresenta um grau de incerteza maior diante da exigência de prestação do serviço para se auferir receitas. Note-se, ainda, que as concessões envolvem contratos de longo prazo, e desse modo apresentam diversos tipos de riscos, tais como: financeiro, político, operacional, de regulação e operacional. A título de exemplo, cita-se o caso do racionamento de energia elétrica ocorrido em 2001 no Brasil, quando a previsão do fluxo de caixa das distribuidoras não se realizou durante pelo menos um ano.

Nesse sentido, a norma apresenta como ponto negativo a "não" referência a esses riscos, mesmo considerando que a mensuração dos riscos é matéria polêmica de difícil determinação tanto econômica quanto contábil, esta é uma questão a ser analisada em relação aos contratos de longo prazo.

Conforme dito inicialmente, a qualidade da discussão e os aspectos que levam à interpretação da aplicação da essência econômica dos contratos é o aspecto mais relevante apresentado pela IFRIC-12.

Em sintonia com o movimento de adoção dos padrões internacionais de contabilidade, a Aneel publicou o Despacho $n^{0} 4.796$, de 24/12/2008, que aprova e torna obrigatório para todas as distribuidoras, permissionárias e autorizadas do setor elétrico, os seguintes pronunciamentos técnicos emitidos pelo Comitê de Pronunciamentos Contábeis - CPC:

O reconhecimento do crédito com referência à fase de acabamento de uma transação é muitas vezes referido como o método da percentagem de acabamento. Por este método, o crédito é reconhecido nos períodos contábeis em que os serviços sejam prestados. O reconhecimento do crédito nesta base proporciona informação útil sobre a extensão da atividade de serviço e desempenho durante um período. Quando o desfecho da transação que envolva a prestação de serviços não pode ser estimado com confiabilidade, o crédito somente deve ser reconhecido na medida em que sejam recuperáveis os gastos reconhecidos. 
Estrutura Conceitual e os de $\mathrm{n}^{\mathrm{o}} 01$ ao $14^{33}$, determinando que se houver conflito entre as disposições regulatórias e essas normas, a Aneel deve ser previamente consultada.

Com a mesma data publicou o Ofício Circular n⿳ำ 2775/2008-SFF/ANEEL, no qual orienta todas as distribuidoras, permissionárias e autorizadas de energia elétrica quanto aos aspectos contábeis que deverão ser observados por ocasião do encerramento e divulgação das demonstrações contábeis do exercício social de 2008.

Aspecto relevante do conteúdo desse ofício a ser ressaltado é o que consta dos parágrafos 24 a 29 sobre Ativo Intangível.

No parágrafo 24 destaca que deve ser observado o Pronunciamento Técnico do CPC 04 - Ativo Intangível, devendo as distribuidoras proceder à reclassificação do seu ativo diferido. Em seguida alerta que a norma não se aplica a valores decorrentes do ativo imobilizado referente à aquisição de bens vinculados ao objeto da concessão outorgada pela União Federal, os quais deverão permanecer no ativo imobilizado.

No parágrafo 25 informa que o MCSPEE, na conta Ativo Imobilizado - Intangível, já previa o registro das imobilizações vinculadas à concessão do serviço público de energia elétrica que serão transferidas ao poder concedente sem indenização ao término da concessão por serem amortizadas no período concessivo, podendo referir-se, também, a bens físicos. Ou seja, refere-se a uma situação na qual a distribuidora tem apenas o direito de uso, o qual, por sua vez, representará uma imobilização intangível para os efeitos contábeis.

Já os custos com novos investimentos aprovados pelo regulador, cujo saldo remanescente será objeto de indenização ao final da concessão, não devem ser objeto de transferência para o ativo intangível e nem do cálculo de amortização complementar. A infraestrutura deve permanecer contabilizada no ativo imobilizado e ser depreciada de acordo com as regras que regem o tema.

Outro ponto relevante é apresentado no parágrafo 30, que orienta sobre a utilização do Pronunciamento Técnico do CPC 01- Redução ao Valor Recuperável de Ativos. O ofício diz que deve ser observado que os bens vinculados à concessão do serviço público, sujeitos à

33 Pronunciamentos aprovados pelo CPC: Pronunciamento Conceitual Básico - Estrutura Conceitual; Pronunciamento Técnico CPC-01 - Redução ao Valor Recuperável de Ativos; Pronunciamento Técnico CPC-02 - Efeitos das mudanças nas taxas de câmbio e conversão de demonstrações contábeis; Pronunciamento Técnico CPC-03 - Demonstração do Fluxo de Caixa; Pronunciamento Técnico CPC-04 - Ativo Intangível; Pronunciamento Técnico CPC-05 Divulgação sobre Partes Relacionadas; Pronunciamento Técnico CPC-06 Operações de Arrendamento Mercantil; Pronunciamento Técnico CPC-07 - Subvenção e Assistência Governamentais; Pronunciamento Técnico CPC-08 - Custos de Transação e Prêmios na Emissão de Títulos e Valores Mobiliários; Pronunciamento Técnico CPC-09 - Demonstração do Valor Adicionado; Pronunciamento Técnico CPC-10 - Pagamento Baseado em Ação; Pronunciamento Técnico CPC-12 - Ajuste a Valor Presente; Pronunciamento Técnico CPC-13 - Adoção Inicial da Lei no 11.638/07; e Pronunciamento Técnico CPC-14 Instrumentos Financeiros: Reconhecimento, Mensuração e Evidenciação. 
reversão nos termos da legislação vigente, a princípio terão sua recuperação conforme critérios estabelecidos na Resolução Aneel no 234/2006 ${ }^{34}$, alterada pela Resolução Aneel no $338 / 2008^{35}$, já aplicada às distribuidoras de distribuição de energia elétrica e às distribuidoras de transmissão cuja concessão não tenha sido objeto de licitação.

Informa que se deve considerar esse parâmetro como limitador para fins de registro de eventuais desvalorizações, quando da elaboração do fluxo de caixa descontado, observado o prazo limite do contrato de concessão, nos termos da legislação vigente.

Depois da publicação desse ofício de encerramento, a Aneel, contando com a participação de agentes do setor, principalmente a Associação Brasileira dos Contadores de Energia elétrica - $\mathrm{ABRACONEE}^{36}$, considerando que a entrada em vigor imediata das medidas espalharia incertezas no mercado ao confrontar práticas e direitos reconhecidos nos contratos de concessão assinados em decorrência de processos licitatórios e homologados pela própria Aneel, publicou o Ofício circular n⿳0 127/2009-SFF/ANEEL, alterando o ofício de encerramento $\mathrm{n}^{\mathrm{o}}$ 2.775/2008-SFF/ANEEL, acima citado.

O ofício apresenta as alterações referentes ao ativo intangível e redução do valor recuperável dos ativos, e estão transcritos abaixo:

\begin{abstract}
Com referência a letra "i - ATIVO INTANGÍVEL - CONCESSÕES DE GERAÇÃO E TRANSMISSÃO" do item 1.3.1 - ATIVO, face às contribuições e argumentos apresentados, procedemos a uma análise mais aprofundada dos contratos de concessão e das autorizações junto à área de regulação e, considerando esses atos de outorgas, a legislação vigente, e que esse assunto deverá ser objeto de decisão da Diretoria Colegiada da ANEEL em 2009, a determinação constante dos parágrafos 25 a 29 do Ofício em epígrafe deve ser desconsiderada.

6. Com referência à letra "J - REDUÇÃO AO VALOR RECUPERÁVEL DE ATIVOS", que consta erroneamente como letra "I", tratada no parágrafo 30, mesmo considerando a aplicação da Resolução Aneel no 234/2006, alterada pela Resolução Aneel $n^{\circ}$ 338/2008, em algumas situações de revisão tarifária de transmissora e em distribuidoras de distribuição detentoras de ativos de geração, de fato não existe uma norma regulatória sobre o assunto. Assim, esse dispositivo passa a ter a seguinte redação:

"30. Deverá ser observada a aplicação do Pronunciamento Técnico CPC $n^{\circ}$ 01, aprovado pela Aneel por meio do Despacho $n^{\circ} 4.796$, de 24.12.2008, da Superintendência de Fiscalização Econômica e Financeira - SFF."
\end{abstract}

\footnotetext{
${ }^{34}$ A Resolução 234/2006 estabelece os conceitos gerais, as metodologias aplicáveis e os procedimentos iniciais para realização do segundo ciclo de Revisão Tarifária Periódica das distribuidoras de serviço público de distribuição de energia elétrica.

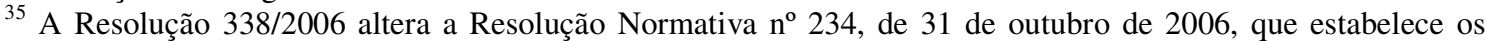
conceitos gerais, as metodologias aplicáveis e os procedimentos iniciais para realização do segundo ciclo de Revisão Tarifária Periódica das distribuidoras de serviço público de distribuição de energia elétrica.

${ }^{36}$ A Associação Brasileira dos Contadores do Setor de Energia Elétrica - ABRACONEE é uma Sociedade Civil, sem fins lucrativos, fundada em 06 de novembro de 1986, que congrega os profissionais de Contabilidade, vinculados ao Setor de Energia Elétrica (www.abraconee.com.br).
} 
Ao alterar os termos do Ofício de Encerramento n⿳ํㅡㄹ 2.775/2008 e sinalizar que estes procedimentos deverão ser aprovados pela diretoria colegiada do regulador e precedidos de Audiência Pública, a Aneel demonstra sua preocupação com o mercado, mas deixa evidente ao aprovar todos os pronunciamentos do Comitê de Pronunciamentos Contábeis - CPC que as regras serão adotadas e que os agentes devem se preparar para isso e que este recuo se dá considerando a necessidade de um período de assimilação, interação e amadurecimento dos normativos pelos agentes envolvidos.

\subsection{CONSIDERAÇÕES DE FINAL DE CAPÍTULO}

Este capítulo abordou os objetivos da contabilidade regulatória em relação aos objetivos da contabilidade societária e os normativos internacionais referentes à contabilização de contratos entre concessor e operador.

Destaca-se que as interpretações internacionais são relevantes não pelo poder normativo e sim pela riqueza da argumentação qualitativa contida nos documentos.

Foi verificado que no caso do setor elétrico, o regulador utiliza a contabilidade societária como partida para estabelecimento de uma contabilidade regulatória na qual há a necessidade do detalhamento da especificidade das entidades reguladas para permitir o controle e o monitoramento da atividade concedida através do contrato de concessão.

A contabilidade regulatória foi criada para um fim específico, tendo um objetivo convergente com a contabilidade societária. No entanto, se aprofunda na busca da correta demonstração da situação econômica e patrimonial da atividade concedida, servindo ainda como instrumento de controle e monitoramento dessa atividade.

Percebe-se pelos casos específicos analisados que a contabilidade regulatória vai além da contabilidade societária para atender as necessidades de seu principal usuário, o poder concedente representado pela figura do regulador.

Quanto aos usuários em geral, cabem duas reflexões apresentadas anteriormente. A primeira discute se a contabilidade está atendendo aos seus objetivos, verificando a utilização dela por parte de seus usuários; a outra discute se a contabilidade está aderente de alguma forma explícita ou implícita àquilo que o usuário considera como elemento importante para seu processo decisório. Observa-se, nesse sentido, a efetiva contribuição da contabilidade para o alcance de tais objetivos.

Aspecto relevante a ser considerado é que, com a mudança do modelo contábil atual para um modelo que busca a evidenciação da essência econômica das transações, 
especificamente as normas internacionais referentes à contabilização das empresas sob regime de concessão, nota-se a contribuição desse novo modelo para a regulação econômica do setor elétrico brasileiro ao empregar a contabilidade regulatória.

Para discutir essa contribuição é necessário apresentar o ambiente institucional regulatório, os subsídios da contabilidade regulatória e as variáveis contábeis no processo de regulação econômica, temas tratados a seguir. 


\section{A CONTABILIDADE REGULATÓRIA NA REGULAÇÃo ECONÔMICA}

Este capítulo tem como objetivo investigar o papel da contabilidade regulatória na regulação econômica do setor elétrico, evidenciando quais instrumentos contábeis são utilizados nas funções regulatórias de fiscalização e tarifação (formação do preço), com vistas à fixação e manutenção do equilíbrio econômico-financeiro previsto no contrato de concessão. Busca-se, também, identificar restrições ou se há benefícios na adoção das normas internacionais de contabilidade.

Entretanto, para melhor entendimento do contexto no qual a contabilidade regulatória está instalada, é necessário abordar primeiramente o ambiente regulatório e algumas interpretações sobre equilíbrio econômico-financeiro.

\subsection{AMBIENTE INSTITUCIONAL REGULATÓRIO}

O processo de reestruturação do setor elétrico brasileiro tem como fundamento a regulamentação do artigo $175^{37}$ da Constituição Federal do Brasil (1988) por meio da legislação que trata das concessões de serviços públicos, em especial a Lei $\mathrm{n}^{\mathrm{o}}$ 8.987, de 13/02/1995, também conhecida como Lei das Concessões.

Essa lei prevê que cabe ao poder concedente (União, Estados ou Municípios) a delegação da prestação do serviço público, mediante licitação sob concorrência, a empresas jurídicas ou consórcio de empresas que demonstrem capacidade para tal empreitada.

Para fins de implementação da Lei das Concessões, foram criados no Brasil diferentes órgãos reguladores, tais como: Agência Nacional de Telecomunicações - Anatel, Agência Nacional de Energia Elétrica - Aneel, Agência Nacional do Petróleo - ANP, para atuação na concessão e fiscalização dos serviços públicos da área de sua competência, em nome da União (poder concedente).

\footnotetext{
${ }^{37}$ Art. 175: "Incumbe ao Poder Público, na forma da lei, diretamente ou sob regime de concessão ou permissão, sempre através de licitação, a prestação de serviços públicos.

Parágrafo único: A lei disporá sobre:

I - o regime das empresas distribuidoras e permissionárias de serviços públicos, o caráter especial de seu contrato e de sua prorrogação, bem como as condições de caducidade, fiscalização e rescisão de concessões ou permissão;

II - os direitos dos usuários;

III - política tarifária;

IV - a obrigação de manter o serviço adequado".
} 
Nesse sentido, a Lei $n^{0}$ 9.427, de 26/12/1996, que instituiu a Agência Nacional de Energia Elétrica -Aneel, estabelece que a Agência tem por finalidade a regulação e fiscalização das concessões de energia elétrica e que compete também a ela efetuar o controle das tarifas de distribuição através da homologação de reajustes e da execução dos processos de revisão tarifária periódica e extraordinária.

Essa lei disciplina o regime de concessões de serviços públicos de energia elétrica e prevê ainda o regime tarifário de "serviço pelo preço" pelo qual as tarifas máximas do serviço público de energia são aquelas fixadas no contrato de concessão resultante da licitação, no contrato de prorrogação da concessão ou no contrato de concessão originado de desestatização da Aneel.

$\mathrm{O}$ art $3^{\circ}$ dessa lei, que remete à Lei das Concessões, estabelece ainda que a Aneel deve regulamentar o serviço concedido e fiscalizar permanentemente a sua prestação, aplicar as penalidades regulamentares e contratuais, cumprir e fazer cumprir as disposições regulamentares do serviço e as cláusulas contratuais da concessão dentre outros.

$\mathrm{Na}$ Lei das Concessões, art. 9ํㅡㄹ , parágrafo $2^{\underline{0}}$, encontra-se disposto que os contratos de concessão poderão prever mecanismos de revisão das tarifas a fim de manter-se o equilíbrio econômico-financeiro. Nesse aspecto, ressalte-se o disposto no art. $10^{\circ}$ da referida lei, onde se observa que sempre que forem atendidas as condições do contrato considera-se mantido seu equilíbrio econômico-financeiro (grifo da autora).

Nesse sentido, o aspecto inovador é o principio do equilíbrio econômico-financeiro nos contratos de concessão. A lei transfere para os contratos de concessão as definições das regras de funcionamento dos serviços públicos a serem delegados, bem como as garantias dos seus usuários. Embora o equilíbrio econômico-financeiro seja dinâmico e o poder concedente possa mudar unilateralmente as cláusulas contratuais, isso só poderá ser feito se mantido aquele equilíbrio.

A tarifa é o principal instrumento utilizado pelo regulador para se obter e manter o equilíbrio econômico-financeiro previsto no contrato de concessão. Quanto às regras de formação das tarifas e garantia de manutenção do equilíbrio econômico-financeiro, é necessário apresentar o que dispõe a Lei das Concessões - Art. 9ํㅜㄹ

Art. $9^{\underline{0}}$ - A tarifa do serviço público concedido será fixada pelo preço da proposta vencedora da licitação e preservada pelas regras de revisão prevista nesta Lei, no edital e no contrato.

$\S 2^{\circ}$ Os contratos poderão prever mecanismos de revisão das tarifas a fim de manterse o equilíbrio econômico-financeiro (grifo da autora). 
Atendendo ao preceito legal, os contratos de concessão contêm em seu corpo cláusulas de reajustes e revisões tarifárias. No entanto, de forma similar à Lei das Concessões, pecam por não apresentar a definição do que vem a ser equilíbrio econômico-financeiro, deixando assim para o regulador a difícil tarefa de aplicar as regras de regulação tarifária de maneira a atender o dispositivo que prevê o equilíbrio sem conceituá-lo.

Assinados os contratos, dá-se início a um processo regulamentar onde as tarifas são homologadas e estabelecidas pelo poder concedente de forma a cobrir os custos de prestação dos serviços, garantir os investimentos necessários para sua ampliação e melhoria de qualidade e remunerar o capital investido no empreendimento.

Nesse contexto, percebe-se mais claramente que o estabelecimento de tarifas pelo órgão regulador é o instrumento para se garantir o equilíbrio econômico-financeiro do contrato de concessão. A previsão do reajuste tarifário nos contratos de concessão tem os seguintes principais aspectos relacionados ao equilíbrio econômico-financeiro:

a) as tarifas estabelecidas para o contrato de concessão são máximas (preço-teto);

b) a distribuidora (investidor) reconhece que as regras de reajuste e revisão tarifária são suficientes para a adequada prestação dos serviços e para a manutenção do equilíbrio econômico-financeiro do contrato;

c) as tarifas serão reajustadas anualmente por uma fórmula paramétrica ${ }^{38}$. Além disso, o contrato será objeto de revisão tarifária periódica em prazo estipulado no contrato (a cada quatro ou cinco anos) para adequação de valor da tarifa, considerando as alterações na estrutura de custos e de mercado da distribuidora, os níveis de tarifas observados em empresas similares no contexto nacional ou internacional e os estímulos à eficiência e à modicidade das tarifas;

d) havendo alteração unilateral do contrato que afete o seu inicial equilíbrio econômico-financeiro, o órgão regulador deverá restabelecer o equilíbrio a partir da data da alteração mediante comprovação da distribuidora, podendo a qualquer tempo proceder à revisão das tarifas.

Conclui-se, portanto, que a manutenção do equilíbrio econômico-financeiro pode ser viabilizada através de regras, procedimentos e mecanismos regulatórios incluídos nas sistemáticas de reajuste anual e de revisões tarifárias periódicas.

\footnotetext{
${ }^{38}$ A fórmula está descrita no Anexo I desta dissertação.
} 
Alem disso, decorrentes do papel de regulador, as funções de fiscalização e regulação tarifária são exercidas pela Aneel por meio do monitoramento das demonstrações financeiras e da fixação de preços, respectivamente. Esses tópicos são tratados a seguir.

\subsection{OS SUBSÍDIOS CONTÁBEIS NA FISCALIZAÇÃo ECONÔMICA E FINANCEIRA}

A função de fiscalização dos serviços de distribuição de energia elétrica estabelecida pela Lei das Concessões é realizada pela Aneel por meio da Superintendência de Fiscalização Econômica e Financeira - SFF, que se dá, primordialmente, pelo monitoramento e auditoria das informações contábeis e tem o propósito de averiguar a gestão e o controle e evidenciar a situação econômico-financeira dos agentes regulados.

Segundo divulgado pela Aneel $(2008)^{39}$, conceitualmente a fiscalização abrange os seguintes enfoques:

a) acompanhamento do desempenho dos agentes com base em informações deles recebidas (informações essas objeto de regulação contábil). A Aneel acompanha vários itens de controle, avaliando o desempenho, o cumprimento das obrigações contratuais e da regulamentação setorial, bem como da legislação vigente;

b) visitas de fiscalização, ou seja, o exercício da fiscalização in loco para verificar se os procedimentos adotados pelos agentes são condizentes com o que expressam os contratos de concessão, os regulamentos e a legislação, além de servir para validar dados e informações afim de subsidiar os processos decisórios da Aneel, em especial os referentes às revisões tarifárias.

Segundo Schmidt e Blowing (2005), mecanismos que estabelecem sanções pelo descumprimento de acordos, contratos e leis são comumente chamados de mecanismos de enforcement. A esse respeito a literatura aponta que o regulador deve prever mecanismos de enforcement (execução) entendidos como aqueles utilizados com o intuito de fazer cumprir as regras formais (ex.: leis e resoluções) e informais (ex.: solicitação de informação).

Há pelo menos dois mecanismos de enforcement: 1) a expectativa de punição dos desvios por uma autoridade superior; ou 2) incentivos gerados pelo próprio contrato para o

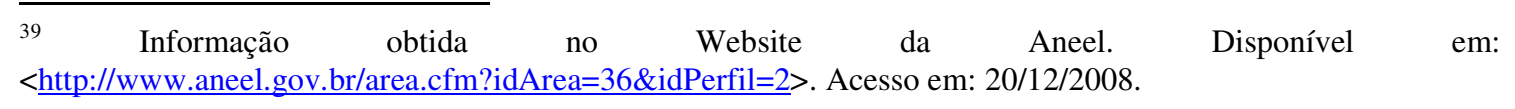


seu cumprimento (em outras palavras, o contrato pode ser self enforcing). Ainda assim, o contrato pode ser descumprido dada a influência de outros custos - os de transação - nas decisões dos contratantes (SCHMIDT E BLOWING, 2005).

Neste sentido, os mecanismos de enforcement adotados pela Aneel com vistas ao cumprimento das disposições contidas no contrato, leis em geral e específicas, estão evidenciados na atuação da Agência por meio dos seguintes instrumentos:
a) fluxo de informações contábeis;
b) fiscalização in $l_{\text {oco }}^{40}$;e
c) concessão de anuências.

O fluxo das informações contábeis permite o acompanhamento da situação econômica e financeira, que é feito por meio da validação do Balancete Mensal Padronizado - BMP, do Relatório de Informações Trimestrais - RIT e da aprovação da Prestação Anual de Contas PAC. Esses demonstrativos são enviados à Aneel/SFF mensalmente, trimestralmente e anualmente, respectivamente. São realizados testes de validação e consistência, tais como grupo de contas diferente do estipulado pelo Manual de Contabilidade do setor e valores que apresentem variação fora do comum. Sendo detectada alguma anormalidade, a distribuidora é informada para que realize os ajustes necessários.

No caso da PAC, esta é composta pelas demonstrações financeiras exigidas a cada exercício pela Lei $n^{0}$ 6.404/76, além de outras previstas na Resolução Aneel nº 64/1998. Essa Resolução estabelece que os concessionários e permissionários publiquem as demonstrações financeiras até o dia 25 de abril do ano seguinte e as apresente à Aneel, juntamente com a composição do capital social, o balanço social, a demonstração do fluxo de caixa e a demonstração do valor adicionado e, quando aplicável, devem enviar também o relatório da administração, o parecer do auditor independente sobre as demonstrações contábeis, o relatório de recomendações dos auditores independentes para aprimoramento dos controles internos, o parecer dos auditores independentes sobre as mutações do ativo imobilizado, o relatório do conselho de administração, o parecer do conselho fiscal e as demonstrações contábeis de empreendimentos em condomínios e consórcios em função do serviço concedido.

\footnotetext{
${ }^{40}$ A fiscalização in loco refere-se à fiscalização na sede da distribuidora.
} 
Esses demonstrativos são submetidos à Aneel/SFF que realiza uma análise com base no estabelecido no Manual de Contabilidade do setor e que, se em conformidade, aprova a PAC.

Tanto o envio das informações nas datas solicitadas como a aprovação da PAC Prestação Anual de Contas - seguem normas específicas da contabilidade regulatória e o seu descumprimento sujeita a distribuidora a penalidades.

A fiscalização in loco é efetuada anualmente e tem como principal fonte de dados e informações os demonstrativos financeiros indicados acima. É executada pela Aneel em conjunto com uma empresa de auditoria externa com tradição reconhecida pelo mercado, visando à obtenção de apoio técnico de equipe de auditores experientes, pressupondo, ainda, transparência nos trabalhos realizados e dando credibilidade aos diversos setores interessados quanto aos resultados alcançados.

Todos os pontos levantados durante o acompanhamento anual do BMP e RIT são averiguados. Ao final da fiscalização é elaborado relatório contendo o resultado do trabalho, com apontamentos que figuram como recomendações ou determinações, sendo estas últimas de caráter mais grave no sentido de que houve o descumprimento de alguma norma.

As recomendações ou sugestões de aprimoramento podem ser acatadas ou não e são de caráter preventivo, não gerando nenhum tipo de penalidade. Já as determinações devem ser obrigatoriamente acatadas sob pena de incorrer em advertência, multas e até mesmo na cassação da concessão.

Essas recomendações e/ou determinações são acompanhadas pelo Relatório de Acompanhamento de Fiscalização - RAF, que contém todos os pontos de fiscalização evidenciados pela auditoria e o status do procedimento adotado para sanar a falha apontada. O RAF por empresa está disponível no sítio da Aneel (www.aneel.gov.br).

Quanto à concessão de anuências, esta se refere à autorização da Aneel para transações que envolvam mudanças patrimoniais ou que possam vir a comprometer a saúde financeira da empresa. São relacionadas à transferência de controle societário, oferecimento de bens e direitos em garantia, contratação com partes relacionadas, desvinculação de bens vinculados à prestação de serviço público de energia elétrica, alterações de atos constitutivos, transferência de concessões, etc.

Nos casos de mudança de controle acionário, as distribuidoras necessitam de autorização prévia da Aneel, o que inclui casos de incorporação, cisão e fusão. Esse processo é aprovado pela diretoria colegiada do órgão em resolução específica. 
A título de ilustração cita-se que de 1997 a 2007, foram aprovados 168 processos de reestruturação societária. As maiores concentrações ocorreram nos anos de 2006 e 2007, com aprovação de 43 e 44 processos, respectivamente ${ }^{41}$. A tabela abaixo evidencia o quantitativo desses processos por ano.

Tabela 1 - Quantitativo de aprovação de reestruturação societária

\begin{tabular}{|c|c|}
\hline Ano & Aprovação de Reestruturação Societária \\
\hline 1997 & 1 \\
\hline 1998 & 7 \\
\hline 1999 & 6 \\
\hline 2000 & 4 \\
\hline 2001 & 9 \\
\hline 2002 & 7 \\
\hline 2003 & 14 \\
\hline 2004 & 17 \\
\hline 2005 & 16 \\
\hline 2006 & 43 \\
\hline 2007 & 44 \\
\hline Total & $\mathbf{1 6 8}$ \\
\hline
\end{tabular}

Conforme citado no item 2.2.3.3 deste trabalho, os processos de reestruturação societária só começaram a ocorrer em maior volume com a publicação da Lei 10.848/2004, após esse ano, como pode ser observado na tabela acima foram aprovados 120 processos de reestruturação.

\subsubsection{Casos de atuação da fiscalização econômico-financeira}

Os objetos da fiscalização, o fluxo de informações e a fiscalização in loco são direcionadores e norteiam as ações tomadas pela Aneel que os utiliza para exercer o controle da atividade regulada, com vistas à manutenção do equilíbrio econômico-financeiro da concessão. Nesse sentido, podemos visualizar em alguns casos tal atuação.

\footnotetext{
${ }^{41}$ Importante debate sobre as estratégias usadas pelas distribuidoras nas mudanças de controle acionário pode ser visto em Costa (2006).
} 


\subsubsection{Caso da Companhia Energética de Roraima - CER}

O caso da companhia energética de Roraima-CER ocorreu em 2005, quando a Aneel decidiu sugerir ao Ministério de Minas e Energia que viabilizasse a federalização da empresa, tornando a concessão extinta, visando garantir a prestação do serviço à população.

Segundo o relatório de voto do processo 48.500000888/00-12, de 22 de dezembro de 2005, a Aneel argumentou que a empresa descumpriu determinações de fiscalizações realizadas entre 1998 e 2001 em prejuízo do serviço público de distribuição de energia elétrica. Entre os problemas apontados pela Aneel estavam o desequilíbrio patrimonial, capital de giro insuficiente, perdas elevadas, inadimplência alta principalmente por parte do poder público, alto nível de endividamento de curto prazo, desempenho operacional afetado pelos prejuízos contínuos e crescentes, entre outros.

Com base no monitoramento da gestão econômico-financeira e nos resultados de 2003, foram extraídos indicadores que não asseguravam a continuidade das operações e, ao contrário, indicavam que a empresa caminhava para situação falimentar (Processo 48.500888/00-12).

Esse ato demonstrou a credibilidade por parte da Agência nos demonstrativos financeiros para a análise de viabilidade econômico-financeira, que apontaram no sentido da situação degradante da distribuidora, servindo de suporte para a tomada de decisão.

\subsubsection{Caso da Companhia Energética do Maranhão - CEMAR}

Outro exemplo da utilização das demonstrações financeiras para a adoção de providências pelo órgão regulador ocorreu na apuração da situação econômico-financeira da Companhia Energética do Maranhão - Cemar, que embasou uma intervenção na administração da distribuidora em 2002.

Segundo a Resolução Aneel 408/2003, que publicou a intervenção, os motivos que levaram a tal ato foram os dados que constaram dos relatórios de fiscalização executados pela Aneel, aliados à análise das demonstrações financeiras desde a privatização do controle acionário da empresa.

A Agência nomeou um interventor que ficou na administração da empresa até 2004, quando, então, encerrou a intervenção considerando que as motivações determinantes não subsistiam mais, tendo em vista as ações adotadas ao longo do período de intervenção que 
asseguravam o cumprimento das obrigações legais e contratuais vinculadas ao contrato de concessão.

\subsubsection{Caso da Empresa Energética do Mato Grosso do Sul - ENERSUL}

Recentemente, em abril de 2008, na revisão tarifária da Empresa Energética do Mato Grosso do Sul - Enersul, foi detectado que a empresa deveria devolver aos consumidores, no período de 12 meses, um passivo financeiro calculado erroneamente na revisão de 2003, estimado em R $\$ 183$ milhões.

Segundo publicado pela Nota Técnica n. ${ }^{\circ}$ 340/2007-SRE/ANEEL, a Aneel, baseou-se na análise dos demonstrativos financeiros da empresa e verificou que ela não tinha capacidade financeira para fazer frente ao tratamento desse passivo no curto prazo. Além disso, constatou que a redução de receita provocada pelo aprovisionamento integral desse passivo levaria a empresa ao descumprimento de cláusulas de cobertura de endividamento (covenants) que possibilitaria aos credores requererem o vencimento antecipado de debêntures no valor total de R \$ 388 milhões. Isso traria um "desequilíbrio financeiro" para a distribuidora.

Diante dessa análise, foi autorizado que o passivo financeiro fosse diluído com correção para os próximos 5 anos, baseado no princípio de que a Agência deve zelar pelo equilíbrio econômico-financeiro da concessão (Processo de Revisão Tarifária da Enersul 48500.004310/2006-30, Voto do Diretor).

\subsubsection{Caso da Centrais Elétricas de Santa Catarina - CELESC}

Em 2007, a Aneel/SFF aplicou multa para a Centrais Elétricas de Santa Catarina CELESC de 0,006\% da receita de faturamento através do Auto de Infração n. 044/2007 em função da distribuidora não ter prestado informações e esclarecimentos solicitados pela equipe de fiscalização, o que caracterizou o descumprimento da subcláusula $2^{\mathrm{a}}$ da Cláusula $8^{\mathrm{a}}$ do Contrato de Concessão no $056 / 99^{42}$.

No relatório de voto do Processo 48500.001408/2007-15, a distribuidora pleiteou a desconstituição da penalidade, sustentando ter prestado as informações dentro do prazo

\footnotetext{
${ }^{42}$ Contrato de Concessão n⿳o 56/1999 - CELESC: Segunda Subcláusula da Cláusula Oitava: Subcláusula Segunda - Os servidores da ANEEL ou seus prepostos, especialmente designados, terão livre acesso, em qualquer época, a pessoas, obras, instalações e equipamentos vinculados ao serviço público de distribuição de energia elétrica, inclusive seus registros contábeis, podendo requisitar, de qualquer setor ou pessoa da DISTRIBUIDORA, informações e esclarecimentos que permitam aferir a correta execução deste Contrato, bem como os dados considerados necessários para o controle estatístico e planejamento do sistema elétrico nacional.
} 
estipulado pela SFF/ANEEL. Por meio do Despacho $n^{\circ} 2.950 / 2007$ a Aneel rejeitou as justificativas apresentadas pela distribuidora e manteve a penalidade. Posteriormente, por meio do Despacho $\mathrm{n}^{\mathrm{o}} 3.433 / 2008$, a penalidade foi reduzida para multa de $0,005 \%$ da receita de faturamento da CELESC.

De modo geral, observa-se a utilização das demonstrações financeiras pelo regulador como instrumento de evidenciação do desempenho econômico-financeiro das distribuidoras e, por conseguinte, do equilíbrio econômico-financeiro previsto no contrato de concessão.

Nota-se também a importância da contabilidade regulatória para os atos do regulador, dando segurança e confiabilidade ao processo de tomada de decisão. Nesse sentido, a atuação do regulador é direcionada para proteger a saúde financeira do negócio e induzir comportamentos que otimizem a eficiência na atividade concedida.

Tanto as transações com partes relacionadas como as operações com bens em garantia, ao serem objetos de aprovação da Aneel, nada mais são que instrumentos de controle utilizados para resguardar a concessão de estratégias direcionadas ao lucro imediato.

A sinalização emitida pela Aneel ao monitorar os atos dos administradores e acionistas, ao aprovar balanços e demonstrativos financeiros e, principalmente, ao punir via Auto de Infração é de que o interesse público está sendo preservado tanto no que se refere ao patrimônio como à prestação do serviço com qualidade, fiscalizando se o gestor da concessão adota comportamentos compatíveis com a geração de valor do negócio e não cria desvios que possam favorecer outras partes interessadas.

Nesse contexto, a contabilidade, com destaque para a área regulatória, apresenta-se como ferramenta essencial para que se obtenha êxito no objetivo buscado.

\subsection{OS SUBSÍDIOS CONTÁBEIS NA REGULAÇÃO TARIFÁRIA}

Para entender o modelo de regulação tarifária adotado pela Aneel é necessário discorrer sobre os aspectos da regulação econômica e da regulação por incentivos, descrevendo alguns conceitos relacionados ao equilíbrio econômico-financeiro buscado pelo regulador no processo de fixação do preço das tarifas. 


\subsubsection{Aspectos da regulação econômica}

A literatura que se tornou conhecida como teoria econômica da regulação teve seu início com Stigler, em 1971, e sua principal característica é assim definida por Peltzman $(1976)^{43}$ :

O que veio a ser chamado como teoria econômica da regulação teve início com um artigo de George Joseph Stigler, em 1971. O elemento mais importante desta teoria é a sua integração da análise do comportamento político com o maior corpo amplo de análise econômica. Os políticos, tal como nós, se presume serem automaximizadores de interesses. Isso significa que grupos de interesses podem influenciar o resultado do processo de regulamentação, fornecendo apoio financeiro ou outros suportes para políticos ou reguladores ${ }^{44}$ (tradução livre).

Para Stigler (1971), a regulação é um bem econômico com oferta e demanda que gera custos para uns e benefícios para outros. Essa abordagem afirma que, na maior parte dos casos, a regulação econômica beneficia a indústria regulada.

Cabe observar também que, ainda de acordo com Stigler (1971), na medida em que se coloca a possibilidade de regulação da atividade econômica pelo Estado, o mercado como instrumento de decisão econômica é substituído pelo processo político de decisão, resultando em ineficiência do ponto de vista econômico. Considera-se que as decisões políticas envolvem um conjunto amplo de questões, uma vez que seria muito custoso promover eleições para cada questão individualmente, impedindo que os eleitores otimizem suas escolhas na margem. Além disso, o processo político envolve toda a comunidade e não apenas aqueles indivíduos interessados diretamente nas questões discutidas (STIGLER, 1971).

Uma contribuição ao utilizar a abordagem agente-principal mudou o enfoque sobre a regulação econômica na década de 1990, ao discutir esquemas de incentivos para corrigir problemas de assimetria de informação: A theory of incentives in procurement and regulation (Laffont e Tirole, 1993). A discussão apresentada a seguir utiliza essa literatura.

A teoria dos incentivos foca o problema da informação e utiliza uma abordagem agente-principal para entender o processo regulatório. O regulador é o "principal", cuja função-objetivo deve ser o bem-estar social. O "agente" é a firma. O "principal" maximiza a utilidade esperada escolhendo a forma ótima de combinar as eficiências produtivas, alocativas

\footnotetext{
${ }^{43}$ Para ver a evolução histórica da regulação econômica, ver Fiani (2001).

${ }^{44}$ What has come to be called the economic theory of regulation, or ET, began with an article by George Stigler in 1971. The most important element of this theory is its integration of the analysis of political behavior with the larger body of economic analysis. Politicians, like the rest of us, are presumed to be self-interested maximizers. This means that interest groups can influence the outcome of the regulatory process by providing financial or other support to politicians or regulators (PELTZMAN, 1989, p. 1).
} 
e distributivas (máxima produção ao menor preço) com adequada transferência de renda (rentabilidade) à firma.

Laffont e Tirole (1993) constroem alguns modelos de regulação sob diferentes hipóteses (informação assimétrica, firmas multiproduto, etc.), em que o principal (regulador) deve maximizar a função de utilidade social e o agente (firma) deve maximizar sua função de produção.

De acordo com Berg (1998, p. 3), é possível identificar as seguintes modalidades genéricas de regulação por incentivos: regulação por comparação, regulação price-cap, regulação pela receita e a licitação.

A regulação por comparação, também conhecida como regulação por desempenho (yardstick regulation), ocorre quando o concessionário é recompensado com base no seu desempenho com relação aos fornecedores comparáveis. As recompensas e penalidades incorridas baseiam-se em dimensões selecionadas (parâmetros) de desempenho do serviço. O agente regulador pode ajustar as medidas de desempenho para levar em conta as diferentes condições operacionais entre os fornecedores.

A regulação price-cap implica na definição de um preço-teto para um período determinado, corrigido de acordo com a evolução de um índice de preços ao consumidor. A empresa regulada tem a liberdade de ajustar seus preços de acordo com um índice inflacionário menos um redutor selecionado (fator $\mathrm{X}$ ) que representaria ganhos de produtividade esperados. $\mathrm{O}$ chamado fator $\mathrm{X}$ é a variável regulada, definido por um período determinado. Esse tipo de regulação proporciona incentivos para as empresas reduzirem custos. Ela também reduz os efeitos da assimetria de informação entre regulados e reguladores.

A regulação pela receita "allowed revenue" aplica os mesmos mecanismos da regulação por price-cap sem limitar as mudanças na estrutura tarifária, transfere o risco de demanda ao usuário, dilui os incentivos à expansão e permite que as receitas acompanhem mais de perto a variação de custos.

A licitação (franchise bidding) é um processo competitivo pelo direito de exploração comercial de um serviço. Nessa modalidade, o governo atua como um leiloeiro ao invés de regulador, cedendo o direito de explorar o serviço de duas maneiras: ganha a empresa que oferecer menor tarifa do serviço ou a empresa que oferecer o maior preço pelo direito de oferecer o serviço para uma dada tarifa.

Segundo Jamasb e Pollitt (2001), o recente interesse pela regulação por incentivos não se deve às contribuições da teoria econômica, mas à insatisfação com o desempenho da 
regulação pela taxa de retorno ou custo do serviço, até então adotada pelos reguladores no mundo.

Esse argumento faz sentido no atual contexto de regulação do setor elétrico adotada no Brasil, onde o modelo utilizado antes das reformas da década de 90 foi a regulação pelo custo do serviço ${ }^{45}$, o qual tem a vantagem de se adequar com facilidade à noção de serviço público (razoabilidade, preços não-discriminatórios e geograficamente uniformes) e objetiva o controle de preços abusivos.

Devido às ineficiências apresentadas na estrutura de regulação pelo custo do serviço ou pela taxa de retorno, com a reestruturação ocorrida no setor a partir de 1995 houve mudanças no método utilizado pelo regulador, que passou a adotar o price-cap.

O desenho regulatório do setor elétrico brasileiro é de um regime de regulação por incentivos do tipo price cap, que tem o seguinte objetivo, de acordo com o regulador brasileiro (Nota Técnica nº 350/2007-SRE/ANEEL):

O principal objetivo da regulação baseada em incentivos, do tipo price cap é replicar a ação que as forças de mercado teriam sobre firmas que atuam em monopólios naturais, de modo a emular o ambiente de um setor competitivo. Isso produz fortes incentivos para redução de custos e inovações tecnológicas, de forma a aumentar a produtividade das empresas.

O modelo adotado envolve a definição de parâmetros referenciais pelo regulador. Por exemplo: estabelece-se um montante de custos operacionais durante um período de tempo de modo que as empresas que obtiverem ganhos de produtividade superiores aos fixados poderão se apropriar desses ganhos. Ou seja, a essência e principal razão da existência de uma regulação por incentivos é estimular os ganhos de produtividade das empresas, o que é feito de duas formas: na revisão tarifária, que ocorre em períodos de 5 em 5 ou 4 em 4 anos dependendo do contrato de concessão, e anualmente através da aplicação do Fator X nos reajustes tarifários.

Assim também está descrito no marco regulatório do setor, a Lei das Concessões (Lei 8.987/1995) e nos contratos de concessão assinados nas privatizações, onde se determinam as diretrizes básicas para o exercício da regulação tarifária. Merece destaque a definição de que as tarifas estabelecidas na assinatura do contrato são máximas (preço-teto) e devem ser

\footnotetext{
${ }^{45}$ Giambiagi (2001, p. 413) diz que na tarifação pelo custo do serviço, também conhecida como regulação da taxa interna de retorno, os preços devem remunerar os custos totais e conter uma margem que proporcione uma taxa interna de retorno atrativa ao investidor.
} 
reajustadas anualmente por um índice de inflação, o IGPM (índice Geral de Preços Mercado), deduzido de um Fator $\mathrm{X}^{46}$.

O marco regulatório prevê, ainda, que sejam feitas revisões tarifárias a fim de se manter o equilíbrio econômico-financeiro (EEF) do contrato e de se calcular o Fator X que deverá vigorar no período regulatório vigente.

Nesse contexto, coube a Aneel definir o detalhamento do desenho regulatório do setor, incluindo as metodologias para as revisões tarifárias periódicas das distribuidoras de distribuição. Na condução desse processo a Aneel valeu-se das audiências públicas para colocar em discussão as propostas metodológicas para aplicação do modelo de regulação do tipo price cap. Além disso, as metodologias deveriam sinalizar aos investidores a atratividade do negócio, permitir o equilíbrio econômico-financeiro e a modicidade tarifária.

A seguir são apresentadas as variáveis do processo regulatório com o objetivo de identificar as variáveis contábeis dentro desse processo.

\subsubsection{Variáveis do processo regulatório}

Segundo Pedell (2006, p. 24), o framework do regime regulatório consiste em grande quantidade de variáveis parcialmente determinadas pelo regulador que definem o escopo dos mercados regulamentados: firmas e decisões, variáveis relativas à concepção básica do sistema de regulação, bem como suas diretrizes contábeis. Essas variáveis influenciam o nível de volatilidade do fluxo de caixa e a estrutura de capital.

O mercado de capital processa essa informação e avalia a firma e, consequentemente, seu custo de capital. O relacionamento e fluxo dessas variáveis podem ser vistos na figura abaixo:

\footnotetext{
46 Segundo a Aneel (NT 350/2007) o índice denominado Fator X refere-se a um redutor aplicado sobre o indexador (IGPM) de modo a refletir os ganhos de produtividades de uma indústria de rede caracterizada por suas economias de escala. No período das privatizações o valor de $\mathrm{X}$ foi fixado pela Aneel igual a zero. A partir de 2003, foi fixado valor de X para cada distribuidora. O Fator X, aplicado como redutor do IGPM, implica que as tarifas poderão ser corrigidas abaixo (e eventualmente acima) daquele indexador, caracterizando ganhos de produtividade de uma empresa regulada para os consumidores. Resumidamente, o cálculo do Fator X implica na projeção dos ganhos de produtividade causados pelas economias de escala dos serviços de distribuição de energia elétrica que resultam em custos incrementais decrescentes.
} 
Figura 2 - Variáveis do framework regulatório

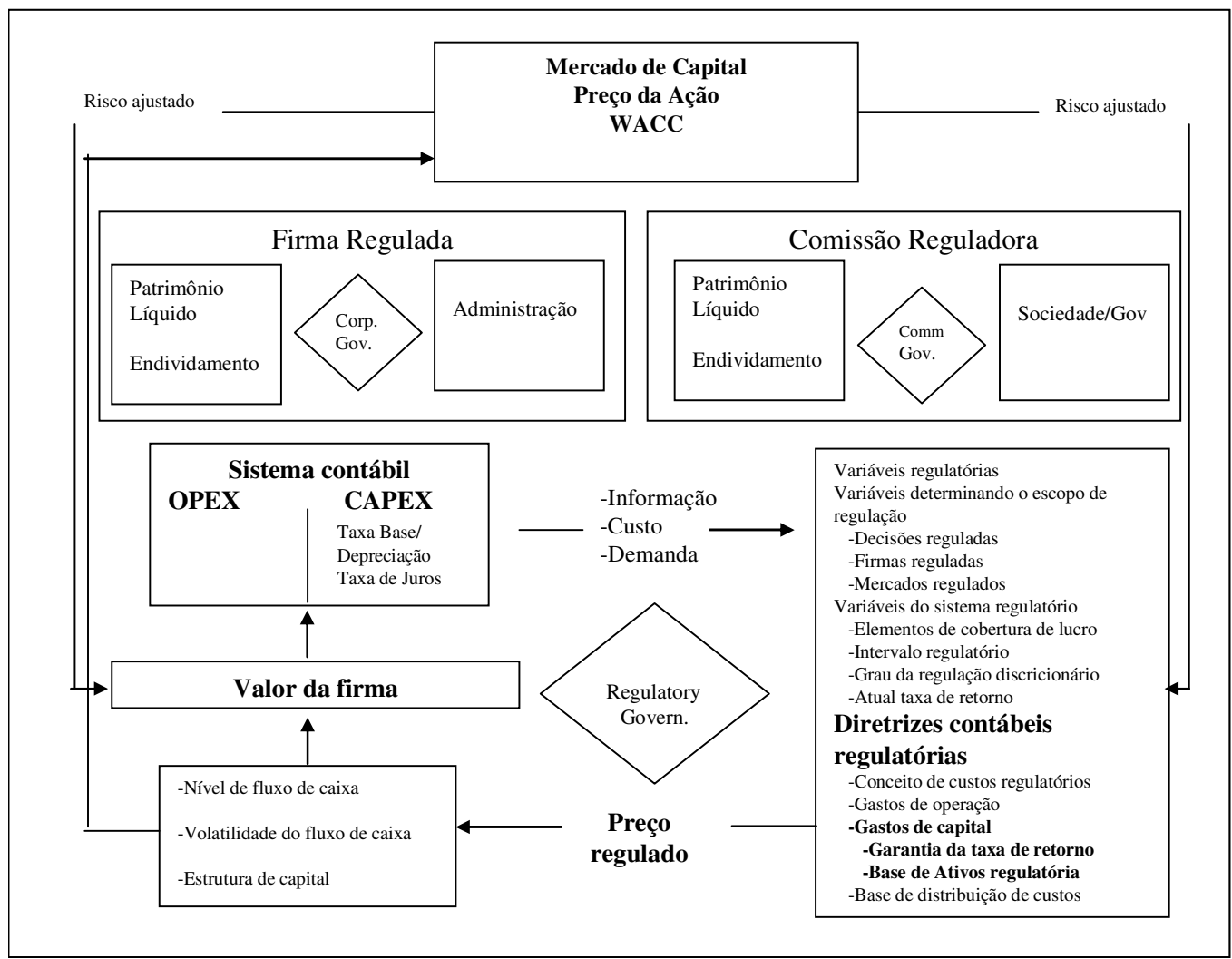

Nota: Itens analisados: sistema contábil, diretrizes contábeis regulatórias e preço regulado.

Fonte: Pedell (2006, p. 24).

O processo regulatório envolve diversas variáveis conforme apresentado no quadro acima. A Aneel (na figura como Comissão Reguladora) tem o papel de definir as variáveis regulatórias de modo a atender seus objetivos, visualizando o contexto e o impacto que as decisões regulatórias causariam.

A análise do quadro indica que as variáveis do processo de fixação de preço ao interferir no fluxo de caixa da empresa impactam o valor da firma. $\mathrm{O}$ valor da firma por sua vez alimenta o sistema contábil da empresa regulada (CAPEX e OPEX) que por sua vez realimenta as informações que comporão as variáveis do regime regulatório. As variáveis regulatórias determinadas no processo de regulação englobam as variáveis contábeis - quais sejam: gastos de operação (OPEX) e gastos com capital (CAPEX) - e alteram os custos com capital (CAPEX).

Mesmo que no quadro não se apresentem as setas indicando o fluxo dos sistemas contábeis e das variáveis regulatórias para a firma e para a comissão reguladora, de acordo com Pedell (2006, p. 26) o nível de volatilidade do fluxo de caixa e a estrutura de capital não 
dependem somente das diretrizes regulatórias, mas também da reação da firma regulada (bem como da reação dos competidores). Por outro lado, isso depende do desenho do sistema regulatório e também do grau de liberdade permitida à firma para reagir à regulação e exercer o controle sobre o próprio fluxo de caixa e custo de capital, como investimentos, financiamentos e decisões de aquisições.

Nesse framework do regime regulatório é possível identificar as diretrizes contábeis utilizadas pelo regulador que impactam o valor de mercado da empresa, atuando sobre os CAPEX (Capital Expenditures - gastos de capital) e os OPEX (Operating Expenditures gastos de operação). Sobre essas variáveis contábeis o autor aponta como sendo as que alimentam as variáveis regulatórias como um todo.

Ao identificar que essas variáveis contábeis estão alimentando as variáveis regulatórias, sua definição se torna importante no processo como um todo. Vale ressaltar que essas variáveis são as mesmas que a Aneel submete à audiência pública para definir a metodologia de cálculo das revisões tarifárias periódicas com a participação de todos os agentes envolvidos (consumidores residenciais, produtores independentes, grandes consumidores, distribuidoras e sociedade em geral). Isso, combinado com o regime de regulação por incentivos e a garantia de equilíbrio econômico-financeiro estabelecida nos contratos, serve como salvaguarda para o exercício de regulação pretendido.

Contudo, como as metodologias para OPEX e CAPEX se apóiam no regime de regulação adotado (por incentivos, tipo price cap) e no comprometimento com a manutenção do equilíbrio econômico-financeiro, estes devem estar claramente definidos.

Nesse sentido, o próximo passo é apresentar as definições referentes ao equilíbrio econômico-financeiro com vistas a atender aos objetivos da regulação econômica.

\subsubsection{Interpretações sobre o equilíbrio economico-financeiro dos contratos de concessão}

A característica fundamental do marco regulatório administrado pela Aneel é a manutenção do equilíbrio econômico-financeiro dos contratos de concessão do setor de energia elétrica (Lei das Concessões) definido na sua formalização. O principal instrumento para alcançar esse objetivo é a revisão tarifária.

Dentre os objetivos do regulador estabelecidos no marco legal do setor elétrico destacam-se a função de fiscalização e a função de fixação de preço. A adequada conjugação dessas funções garante a manutenção do equilíbrio econômico-financeiro dos contratos. 
Nas primeiras revisões tarifárias das distribuidoras de energia elétrica, a Aneel apresentou na Nota Técnica 025/2000 o conceito de equilíbrio econômico-financeiro a ser aplicado aos contratos de concessão:

\begin{abstract}
Equilíbrio Econômico Financeiro (EEF) é um conceito fundamental, em particular no Direito Administrativo brasileiro, que se insere em todos os contratos de concessão das distribuidoras de energia elétrica e até nos contratos iniciais de compra e venda de energia elétrica. No caso específico das distribuidoras de energia elétrica trata-se do equilíbrio econômico financeiro do contrato de concessão, o qual, por sua vez, articula como anteriormente dito, os mecanismos de reajuste anual e revisão tarifária periódica para, em conjunto com a revisão tarifária extraordinária, serem suficientes para manutenção do equilíbrio econômico financeiro.
\end{abstract}

Afirma ainda a Agência nessa Nota Técnica que, na caracterização do equilíbrio econômico-financeiro, as distribuidoras podem se apresentar em duas condições diferentes: uma antes da primeira revisão tarifária periódica, ocorrida em 2003, e outra depois dessa revisão.

Deixa assim claro que o equilíbrio será alcançado através das revisões tarifárias e que as regras e mecanismos destas, que englobam revisão de custos, taxa de rentabilidade, base de remuneração e nível de eficiência, serão os que resultarão no equilíbrio do contrato de concessão.

Acrescenta-se à discussão o que ocorre nos processos de audiência pública sobre metodologia de cálculo de revisões tarifárias, onde os agentes do setor, tais como Associação Brasileira de Distribuidores de Energia Elétrica - ABRADEE e Associação Brasileira de Grandes Consumidores Industriais de Energia e de Consumidores Livres - ABRACE apresentam seu próprio entendimento sobre equilíbrio econômico-financeiro.

A ABRADEE ${ }^{47}$, em 2006, divulgou um estudo sobre as metodologias do segundo ciclo de revisão tarifária que serviu de suporte para pleitos junto à Aneel, contendo propostas de alteração nos cálculos dos componentes da receita a ser cobrada nas tarifas. Nesse estudo, além de questionar todas as metodologias de cálculo, aquela Associação usa como argumento sempre a alegação de que o equilíbrio econômico-financeiro não estaria sendo alcançado. No entanto, não o define expressamente como se observa nos trechos transcritos abaixo:

A desconsideração de tais correções no valor do Ativo Imobilizado em Serviço "inicial", conforme proposto pela Aneel, implicaria num sub-reconhecimento injustificável do valor da $\mathrm{BRR}^{48}$ por mais um período tarifário (ou por toda a vida útil remanescente), comprometendo deste modo o equilíbrio econômico-financeiro da concessão, e desestimulando os investimentos necessários para a continuidade da prestação dos serviços.

$[\ldots]$

\footnotetext{
${ }^{47}$ A Associação congrega as 64 distribuidoras de energia elétrica atuantes no setor, que são responsáveis pela distribuição de $99 \%$ da energia elétrica distribuída no país.

${ }^{48}$ Base de Remuneração Regulatória.
} 
considerando-se as tarifas estabelecidas no primeiro ciclo de Revisão Tarifária Periódica, a receita auferida com o atendimento dos consumidores incorporados em virtude da universalização não é suficiente para cobrir os custos de prestação de serviços associados a estes clientes, comprometendo, assim, o equilíbrio econômico-financeiro do Contrato de Concessão.

Nos pleitos da ABRADEE, a base de argumentação é a preservação do equilíbrio estabelecido em lei e acordado no contrato de concessão. Os trechos acima são exemplos de como é construída a linha de argumentação. A Associação invoca o equilíbrio econômicofinanceiro do contrato de concessão, seja na consideração dos investimentos iniciais na composição da base de incidência da taxa de remuneração, seja na universalização dos serviços de energia elétrica estabelecidos pela Lei $\mathrm{n}^{\mathrm{o}}$ 10.848, de 15/03/2004. Todos os pleitos apresentados geram aumento de receita tarifária ou, nas palavras da Associação, aumento da receita de equilíbrio.

Essa falta de conceituação expressa nos contratos de concessão e na Lei das Concessões cria um espaço para inferências a respeito do que se deve entender como equilíbrio econômico-financeiro desses contratos.

A ABRACE também se posiciona a respeito do equilíbrio econômico-financeiro dos contratos de concessão. Em 2002, o então Diretor-Executivo da ABRACE em entrevista a um jornal sobre as perdas do racionamento acontecido em 2001 e em função do qual as distribuidoras foram contempladas com um encargo de recomposição tarifária extraordinária, alega:

Os contratos de concessão estabelecem que o governo deve garantir o "equilíbrio econômico financeiro das empresas". "Ninguém sabe o que é esse equilíbrio econômico financeiro, quanto deve ser o lucro das empresas, quanto elas devem pagar de juros". Por conta do tal equilíbrio, as distribuidoras de energia foram contempladas com $\mathrm{R} \$ 2,4$ bilhões para repor as perdas que tiveram com o racionamento. Receberam o dinheiro na forma de empréstimo do Banco Nacional de Desenvolvimento Econômico e Social (BNDES) e tiveram direito a um aumento de $2,9 \%$ para os consumidores residenciais e de $7,9 \%$ para os comerciais e industriais o aumento foi concedido para o pagamento do empréstimo. As indústrias que integram a Abrace, que consomem quase metade da energia do país, passaram a ter uma despesa extra de $\mathrm{R} \$ 800$ milhões por mês para pagar a sobretaxa e foi obrigada a cortar a produção no ano passado (JORNAL CORREIO BRASILIENSE, 2002).

A Audiência Pública Aneel 041/2005 serviu de pano de fundo para a discussão do equilíbrio entre a ABRADEE e a ABRACE. A Audiência tinha o fim de regulamentar o Decreto 5.597, de 28/11/2005, que trata do acesso de consumidores livres às redes de transmissão de energia elétrica, estabelecendo a estes o direito de construírem redes próprias de distribuição de energia, sem o auxílio das distribuidoras. 
Um levantamento da ABRACE na área de concessão da Cemig junto aos associados que pretendiam instalar redes próprias mostrou que a medida reduziria a receita da Cemig na tarifa-fio em $0,80 \%$. No caso da receita total, a queda de arrecadação atingiria $0,53 \%$. Para o mesmo caso a ABRADEE previu que a perda na receita total poderia chegar a $7 \%$.

Assim, a CEMIG ressaltou que a Aneel poderia fazer o balanceamento do contrato de concessão, caso fossem percebidas perdas de receita que viessem a afetar o equilíbrio econômico-financeiro da Companhia. Além disso, a empresa poderia pleitear a revisão tarifária extraordinária se constatado o desequilíbrio (Canal Energia, edição de 2/12/2005).

Encontra-se na literatura brasileira estudo denominado Avaliação do Equilíbrio Econômico-Financeiro em Contratos de Concessão de Rodovias, de autoria de uma equipe de pesquisadores da FIPE/USP, coordenada pelo Prof. Roberto Guena de Oliveira, que define o conceito de equilíbrio econômico-financeiro e seus principais determinantes com foco no setor de concessões.

De acordo com Guena et alli (2001, p. 25):

As distribuidoras estão expostas a uma série de riscos políticos e regulatórios. Um dos principais mecanismos legais de proteção das distribuidoras é a garantia do equilíbrio econômico-financeiro dos contratos de concessão. Embora tenha base legal, o conceito de equilíbrio econômico-financeiro não aparece definido nos contratos de concessão.

Também registra a obra que o conceito de equilíbrio em economia é o ponto de partida para uma fundamentação sólida do conceito de equilíbrio econômico-financeiro. A noção de equilíbrio é emprestada da física e significa o estado de um sistema que não apresenta nenhuma tendência interna de mudança, um estado em que toda mudança só pode ser consequência de uma perturbação externa.

Para a definição de equilíbrio econômico equivale a dizer que um sistema econômico encontra-se em equilíbrio caso, para cada um de seus agentes, os benefícios gerados por suas escolhas não sejam inferiores aos custos que elas ocasionam. Isso é verdade desde que as noções de custo e benefícios sejam interpretadas de modo abrangente. Entre outras coisas, é importante ressaltar que os custos e benefícios não precisam estar diretamente associados a valores monetários, pois podem dizer respeito à avaliação subjetiva dos próprios agentes.

Em seu trabalho, os autores também levantam a hipótese de que as empresas distribuidoras teriam por única finalidade em um negócio de concessão a obtenção de lucro. Essa hipótese simplifica bastante a análise, pois permite que algumas fontes de custo/benefício não pecuniárias (tais como um benefício subjetivo obtido pelos acionistas ao 
participar de empresa que gera bons serviços públicos ou, por outro lado, um desconforto dos acionistas preocupados com o impacto das atividades sobre ambiente) sejam desconsideradas.

Outro pressuposto é o de que o negócio da concessão é ótimo para o poder concedente. Em outras palavras, admite-se que o poder concedente considera que os benefícios da concessão superam seus custos e que, no processo de licitação, foi selecionada a distribuidora que ofereceria a melhor combinação disponível de custos e benefícios.

Assumindo essas duas hipóteses, a análise do equilíbrio do contrato de concessão pode concentrar-se na comparação entre custos e receitas da distribuidora. No entanto, surge um problema inicial no fato das receitas e os gastos referentes a um contrato de concessão não se concentrarem em um determinado instante, mas estarem distribuídos ao longo de todo o período de comparação. A primeira tarefa para avaliação da empresa distribuidora consiste, portanto, em comparar valores monetários diferidos no tempo.

Além disso, as receitas e os gastos da concessão não são perfeitamente conhecidos no momento da assinatura do contrato. Isso faz com que o contrato seja de risco. Usualmente, o risco é percebido como um custo adicional por parte dos investidores. Esse efeito, portanto, deve ser levado em consideração na análise do equilíbrio econômico-financeiro.

Sendo assim, Guena et alli (2001) abordam dois cenários: custo de capital homogêneo e ausência de risco; e custo de capital heterogêneo e risco. Para a análise que se pretende neste trabalho e considerando o ambiente regulatório das distribuidoras, é de maior relevância o cenário que trata do custo de capital heterogêneo e risco.

Segundo os autores, um indicador que poderia apontar o equilíbrio econômicofinanceiro de um negócio é dado pela comparação entre a taxa interna de retorno (TIR) e o custo de capital do projeto. A taxa interna de retorno é a particular taxa de desconto que torna nulo o valor presente dos fluxos de caixa do projeto, isto é, ela é a solução da equação:

$$
\sum_{t=1}^{n} \frac{r e c_{t}-\operatorname{des} p_{t_{t}}}{(1+T I R)^{t}}=0
$$

Todavia, a análise do equilíbrio econômico-financeiro de um contrato de concessão através da comparação direta entre a taxa interna de retorno e o custo de capital apresenta algumas dificuldades. Dependendo das características dos fluxos de caixa do contrato em questão, pode haver mais de uma solução para a equação e, portanto, mais de uma TIR. 
Ao considerar o cenário de custo de capital heterogêneo e risco, Guena et alli (2001) afirmam que diferentes fontes de financiamento exigem diferentes remunerações. Há duas razões para que isso ocorra:

a) os mercados financeiros não são completos e perfeitos, de modo que alguns agentes têm acesso a crédito mais barato do que outros;

b) a razão mais profunda, pois explica em grande parte a primeira, e de maior interesse para o tema em questão é que diferentes empreendimentos e diferentes formas de financiar o mesmo empreendimento oferecem riscos diferentes.

O risco de financiar um determinado negócio é afetado pela forma institucional específica do financiamento. Por exemplo: a remuneração do capital dos acionistas de um contrato de concessão depende dos resultados específicos do negócio. Já a remuneração do capital de terceiros é prefixada contratualmente. Os acionistas devem arcar com o custo de capital e com todos os riscos do negócio. Por essa razão o custo de capital próprio costuma ser mais elevado do que o custo de capital de terceiros.

Pelas razões apresentadas, a fórmula inicial deve ser alterada, sendo preciso levar em consideração que:

a) o custo de oportunidade do capital dos acionistas em um momento do tempo $t$ é diferente do custo de oportunidade de terceiros nesse mesmo momento $t$;

b) o custo de oportunidade do capital dos acionistas em um momento do tempo $t$ pode ser diferente do custo de oportunidade desse capital em outro momento do tempo, isso valendo também para o custos de oportunidade do capital de terceiros.

Observadas essas duas condições obtém-se a fórmula necessária para a verificação do equilíbrio econômico-financeiro de um projeto:

$$
F C_{a}(O)+\sum_{t=1}^{T} \frac{F C_{a}(t)}{\left(1+k_{a}\right)}+F C_{b}(O)+\sum_{t=1}^{T} \frac{F C_{b}(t)}{\left(1+k_{b}\right)} \geq 0
$$

Onde:

$\mathrm{FC}_{\mathrm{a}}=$ Fluxo de Caixa do projeto que cabe aos acionistas;

$\mathrm{FC}_{\mathrm{b}}=$ Fluxo de Caixa do projeto que cabe a terceiros;

$\mathrm{K}_{\mathrm{a}}(t)=$ custo capital dos acionistas no tempo $t$; 
$\mathrm{K}_{\mathrm{b}}(t)=$ custo do capital de terceiros no tempo $t$.

Essa condição reflete a heterogeneidade do custo de capital tanto entre fontes de financiamento quanto entre diferentes momentos de tempo. Infelizmente, salvo algumas exceções, ela não pode ser abreviada em uma comparação entre a taxa interna de retorno e um indicador de custo de capital.

Dos conceitos apresentados sobre equilíbrio, a visão dos agentes tem foco nos fluxos de caixa percebidos pela distribuidora e pelos consumidores, já na visão apresentada pela Aneel este equilíbrio está totalmente vinculado aos mecanismos de revisão tarifária, possibilitando a interpretação de que este será resultado da receita de equilíbrio fixada.

Já o conceito apresentado por Guena et alli (2001) diz que a análise do equilíbrio do contrato de concessão pode concentrar-se na comparação entre custos e receitas da distribuidora e que um indicador equivalente do equilíbrio econômico-financeiro de um negócio é dado pela comparação entre a taxa interna de retorno (TIR) e o custo de capital do projeto.

Conforme mencionado anteriormente, o modelo de regulação adotado e as regras de reajuste e de revisão tarifária periódica visam manter o equilíbrio econômico-financeiro do contrato.

A seguir é apresentado o modelo de revisão tarifária periódica adotado pela Aneel com foco nos instrumentos contábeis utilizados na regulação tarifária.

\subsubsection{A revisão tarifária}

Dentro da tarefa de regular, a questão da formação de preços é central, pois envolve aspectos do excedente e sua distribuição. Por essa razão, dentre as atribuições do órgão regulador, o processo tarifário é o que concilia os interesses entre consumidores e distribuidora.

Os contratos de concessão do serviço público de distribuição de energia elétrica são contratos de longo prazo, normalmente com duração de $30 \operatorname{anos}^{49}$. O contrato determina que durante sua vigência a distribuidora deve prestar o serviço público em troca da oportunidade

\footnotetext{
${ }^{49}$ Quando do término do contrato ou quando os bens forem revertidos ao poder concedente, o art. 36 da lei geral de concessões estabelece expressamente que a reversão no advento do termo contratual far-se-á com a indenização das parcelas dos investimentos vinculados a bens reversíveis, ainda não amortizados ou depreciados, que tenham sido realizados com o objetivo de garantir a continuidade e atualidade do serviço concedido.
} 
de arrecadar receitas que sejam suficientes para cobrir os custos operacionais e auferir uma remuneração sobre os investimentos realizados para atender às obrigações do serviço.

A Lei das Concessões (Lei 8.987/1995) e os contratos de concessão assinados nas privatizações determinam as diretrizes básicas para o exercício da regulação tarifária do setor, definindo que as tarifas estabelecidas na assinatura do contrato são máximas (preço-teto) e serão reajustadas anualmente por um índice de inflação, o IGPM (índice Geral de Preços Mercado) deduzido de um Fator X.

O atual modelo de concessão do serviço público de energia elétrica estabeleceu o denominado regime de preços máximos (price cap regulation). Nesse regime, a tarifa, ou preço máximo, é inicialmente fixada e permanece constante em termos reais com base em um indexador estabelecido em contrato por um período de tempo previamente determinado.

O mecanismo price-cap prevê a possibilidade de repasse para os consumidores dos custos variáveis sobre os quais a firma não tem controle (por exemplo, aumento de preços de combustíveis, impostos etc.) durante o intervalo entre as revisões das tarifas (PIRES, 1998).

As características principais desse modelo regulatório são:

a) estabelecimento periódico de tarifas de acordo com os princípios do "price cap" (preço teto);

b) tarifas que vigoram por um período de tempo fixo, após o qual são ajustadas em virtude de inflação e das variações nos custos não gerenciáveis;

c) um ganho econômico que incentive aumentos na eficiência operacional das distribuidoras, com um mecanismo explícito para compartilhar tais ganhos de eficiência com os consumidores.

O price cap é visto como um método tarifário simples e transparente que pode proporcionar o maior grau de liberdade de gestão possível para as empresas em regime de monopólio natural, além de estimular ganhos de produtividade e sua transferência para os consumidores (LITTLECHILD, 1983).

$\mathrm{Na}$ assinatura dos contratos de concessão, as partes assumem que as tarifas a serem aplicadas aos usuários do serviço concedido conferem situação de equilíbrio econômicofinanceiro ao contrato. Essa condição é reanalisada a cada revisão tarifária periódica, que ocorre a cada quatro ou cinco anos, dependendo do contrato de concessão.

Dessa forma, os mecanismos de reajuste e revisão tarifária adotados pelo regulador brasileiro podem ser visualizados no quadro a seguir. 
Quadro 1 - Mecanismos de atualização de tarifas

\section{Reajuste Tarifário Anual}

- Aplicado anualmente entre as revisões tarifárias periódicas.

- Visa a corrigir as perdas do valor da tarifa decorrentes do processo inflacionário.

- Prevê a transferência de parte do aumento de produtividade da empresa ao consumidor, descontando-se do índice de inflação um índice de produtividade.

\section{Revisão Tarifária Periódica}

- Aplicado geralmente a cada quatro anos, dependendo do contrato de concessão.

- Visa a redefinir o preço-teto da tarifa (receita mínima) que garanta o equilíbrio econômico-financeiro das empresas.

- Ajusta o índice de produtividade a ser aplicado nos reajuste anuais.

\section{Revisão Tarifária Extraordinária}

- Aplicado diante de alterações significativas nos custos da empresa, custos estes não previstos nos mecanismos de revisão tarifária periódica ou de reajuste anual.

- Visa a garantir o equilíbrio econômico-financeiro das empresas.

Fonte: Nota Técnica nº 030/2003-SRE/ANEEL.

A revisão tarifária periódica compreende a determinação da receita de equilíbrio e a definição de um Fator $X$ que será utilizado nos anos seguintes para fixação dos reajustes tarifários $^{50}$. No quadro abaixo está demonstrada a formação da receita de equilíbrio e seus componentes.

Quadro 2 - Receita de equilíbrio

\begin{tabular}{|c|c|}
\hline \multicolumn{2}{|c|}{ Receita de Equilíbrio } \\
\hline $\begin{array}{c}\text { Parcela A } \\
\text { (custos não-gerenciáveis) } \\
\text { Compra e Transporte de Energia } \\
+ \\
\text { Encargos Setoriais e Tributos }\end{array}$ & $\begin{array}{c}\text { Parcela B } \\
\text { (custos gerenciáveis) } \\
\text { Custos Operacionais (OPEX) + } \\
\text { Remuneração de Capital (CAPEX) } \\
\text { - } \quad \text { Base de Remuneração x Taxa } \\
\text { de Retorno } \\
\text { - } \quad \text { Quota de Reintegração } \\
\text { Regulatória (Depreciação) }\end{array}$ \\
\hline
\end{tabular}

Fonte: Nota técnica n⿳⺈ 262/2006-SRE/ANEEL.

\footnotetext{
${ }^{50}$ Nos reajustes tarifários que ocorrem nos períodos subsequentes à revisão tarifária periódica. A Parcela B é reajustada por IGPM (-) Fator X (conforme citado no item 3.3.1, esse índice visa garantir o repasse dos ganhos de produtividade aos consumidores). Cabe ressaltar que o processo de reajuste tarifário não está contemplado neste trabalho.
} 
Os custos da Parcela A, composta por custos não gerenciáveis, tem seus valores integralmente repassados ao consumidor via tarifa e são fixados com base no mercado de consumo da distribuidora (compra e transporte de energia) e em legislação específica (encargos setoriais e tributos). A atuação da contabilidade regulatória nessa parcela é de conciliação dos valores pagos e sobre alguma eventual compensação a ser feita.

$\mathrm{Na}$ Parcela B, que agrega os custos gerenciáveis pela distribuidora, é que a contabilidade regulatória atua mais especificamente, seja nos aspectos relacionados ao custo de capital ou naqueles relacionados aos custos operacionais.

É a gestão da Parcela B que permitirá à distribuidora incrementar seus ganhos, principalmente como resultado da realização de custos inferiores aos estabelecidos pelo órgão regulador no cálculo da tarifa e nas revisões periódicas.

Para definição da metodologia de cálculo dos componentes da Parcela B são colocados em audiência pública os procedimentos de cálculo, informações e conceitos a serem utilizados pelo regulador no processo de revisão tarifária. Os mecanismos vigentes para definição dessa parcela são os seguintes:

Quadro 3 - Mecanismos utilizados pelo regulador brasileiro ${ }^{51}$

\begin{tabular}{|l|}
\hline \multicolumn{1}{|c|}{ Mecanismos utilizados pelo Regulador Brasileiro } \\
Base de remuneração $\longrightarrow$ Benchmarking com empresa modelo \\
Taxa de Retorno $\longrightarrow$ Custo de reposição (valor de mercado do ativo em uso) \\
$\begin{array}{l}\text { Quota de Reintegração } \\
\text { Regulatória } \longrightarrow \text { WACC / CAPM de empresa modelo }\end{array}$ \\
\hline
\end{tabular}

Fonte: Nota técnica 262/2006-SRE/ANEEL.

Os subsídios da contabilidade no processo de determinação da receita a ser cobrada via tarifa podem ser vistos nas diversas etapas do processo, tais como: apuração dos investimentos realizados (base de remuneração regulatória), definição dos custos operacionais, remuneração do capital e na sua amortização.

Segundo a Nota Técnica 178/2002 - SFF/ANEEL, a Base de Remuneração Regulatória - BRR se refere à determinação do investimento inicial sobre o qual o concessionário pode auferir a taxa de retorno ou remuneração e constitui-se num dos aspectos-chave para a manutenção do equilíbrio econômico-financeiro estabelecido no contrato de concessão.

\footnotetext{
${ }^{51}$ Esses mecanismos são detalhados nos tópicos seguintes.
} 
Para o investimento inicial a ser considerado como base de remuneração, a Aneel definiu que seria adotado o ativo imobilizado vinculado à concessão do serviço público de distribuição de energia elétrica, avaliado e depreciado. Já a amortização dos investimentos realizados durante a vigência do contrato de concessão, que se refere à recomposição do capital investido pelo concessionário do serviço público, é inserida na receita por meio da chamada "Quota de Reintegração Regulatória".

Esses dois componentes são parte da receita a ser obtida via tarifa e são chamados de "Remuneração Total dos Investimentos". Ressalte-se a relevância da forma de definição e avaliação desses componentes, visto que são eles que sinalizam aos investidores a atratividade do negócio de distribuição de energia elétrica.

Considerando o apresentado por Pedell (2006, p. 24) a determinação das variáveis regulatórias, dentro dessas as variáveis contábeis, influencia o nível de volatilidade do fluxo de caixa da empresa regulada. No caso do regulador brasileiro, as variáveis contábeis estão incorporadas na parcela $\mathrm{B}$, impactando, portanto, o fluxo de caixa da distribuidora e o valor da empresa, tornando a revisão tarifária momento crucial na vida do contrato.

Sendo assim, os subsídios da contabilidade na formação dos componentes da Parcela B, a ser fixada na revisão tarifária periódica, contribuem significativamente para a obtenção do equilíbrio econômico-financeiro previsto no contrato de concessão. A forma de definição metodológica dos componentes é tratada a seguir.

\subsubsection{Custos de Operação (OPEX)}

Os custos operacionais se referem aos dispêndios que a empresa regulada incorre com a gestão, operação e manutenção dos serviços de distribuição de energia elétrica nos níveis de qualidade requeridos.

A Aneel utiliza uma abordagem por comparação para definição desses custos, ou seja, a metodologia definida para determinação dos custos operacionais é uma comparação (benchmarking) com uma Empresa de Referência, que vem a ser um modelo econômico ideal onde só são considerados os custos associados a uma gestão eficiente.

A premissa a ser adotada é a de se estabelecer uma referência de mercado para a determinação dos custos operacionais que seja aderente às condições reais da área geográfica da concessão, ou seja, ao ambiente no qual a distribuidora desenvolve sua atividade. 
Trata-se de desenhar uma referência típica com a qual a distribuidora deverá competir, de modo a incentivá-la a manter seus custos dentro dos valores reconhecidos para lograr a rentabilidade esperada ou até superá-la.

Esse modelo fornece um referencial de gestão para a empresa que lhe permite identificar aquelas atividades e processos em que é possível buscar melhorias em relação ao padrão estabelecido pelo regulador. As melhorias de eficiência na gestão alcançadas são apropriadas pelo prestador do serviço no período entre revisões, o que está em sintonia com o modelo de regulação por incentivos adotado e que induz os agentes em direção à eficiência.

Na revisão tarifária periódica, se os custos de operação fossem reconhecidos com base apenas na análise dos custos incorridos pelas empresas, isto levaria o regulador aos efeitos da assimetria de informação ${ }^{52}$, desenvolvendo assim condições prejudiciais a todos os agentes envolvidos.

Assim, a saída apontada pela regulação por incentivos é o reconhecimento dos custos operacionais com base na comparação entre empresas (empresa de referência), como forma de minimizar os efeitos da assimetria de informações e aumentar o controle que o regulador exerce sobre a qualidade e confiabilidade das informações.

Um trabalho de doutorado apresentado por Tozzini (2006) analisa as consequências da regulação econômica nas estratégias empresariais das distribuidoras de distribuição de energia elétrica com o objetivo de buscar maior entendimento da evolução das práticas de benckmarking no processo de regulação dessas empresas. O autor aborda com profundo detalhe as técnicas de benckmarking e constata que estas vêm se desenvolvendo como ferramentas de administração e instrumentos de regulação.

No desenvolvimento de seu trabalho ele observa que a Aneel faz uso da denominada Empresa de Referência como um processo para fazer frente à assimetria de informação entre o regulador e o regulado. A Empresa de Referência é utilizada como um modelo de comparação para cada empresa regulada e é definida como aquela na qual o preço máximo estabelecido remunera de maneira adequada os investimentos de cada distribuidora regionalmente.

\footnotetext{
${ }^{52}$ De acordo com Pires, Linhares e Oliveira (2000, p. 1): o fenômeno da informação assimétrica envolve duas dimensões principais: uma exógena e outra endógena às firmas, correspondentes, respectivamente, à 'seleção adversa' e ao 'risco moral'. A 'seleção adversa' é provocada pelo fato de o regulador não ter o mesmo nível de informações que a firma regulada a respeito de fatores exógenos que afetam a eficiência da firma (parâmetros tecnológicos, comportamento da demanda, etc). O 'risco moral' é provocado pelo fato de somente a firma ter conhecimento do resultado de determinados movimentos intrinsecamente endógenos (custos, resultado de medidas administrativas, etc), o que gera a possibilidade de manipulação do esforço pelas firmas, objetivando, por exemplo, vantagens na revisão dos contratos ou na estipulação de metas regulatórias.
} 
No trabalho são feitas análises das relações entre as empresas e a Aneel durante o primeiro ciclo de revisões tarifárias periódicas. Da experiência, constata-se que as empresas promoveram mudanças moderadas em suas estratégias funcionais e específicas em função dos critérios utilizados e dos custos estabelecidos pela Empresa de Referência.

Conclui-se que o modelo adotado pela Aneel é uma modalidade complexa, híbrida dos regimes de regulação por incentivos e carece de aperfeiçoamento para a implantação com sucesso da sistemática da empresa de referência.

\subsubsection{Remuneração de Capital (CAPEX)}

A remuneração total de capital incluída nas tarifas de energia elétrica está diretamente relacionada aos custos do capital investido na concessão. A remuneração total de capital (custo com capital) encerra um conceito semelhante ao de quando se faz um empréstimo bancário, onde o tomador paga o custo de oportunidade do capital (taxa de juros ou taxa de remuneração do capital) bem como o principal (amortização do capital).

No caso do serviço regulado, é como se o prestador estivesse fazendo um empréstimo para o ente público no valor equivalente aos investimentos realizados e por esse empréstimo, por meio das receitas obtidas dos usuários, serão pagos o custo do capital e as amortizações do principal.

A remuneração total de capital que compõe as tarifas de energia elétrica considera dois componentes:

a) a remuneração dos investimentos realizados;

b) a quota de reintegração regulatória.

A remuneração dos investimentos é resultado da aplicação de uma taxa fixada regulatoriamente sobre o valor dos ativos disponibilizados para a prestação do serviço e ainda não completamente depreciados, denominada de Base de Remuneração Regulatória - BRR, que, em tese, corresponde ao capital investido ainda não amortizado. A recomposição do capital é denominada de quota de reintegração regulatória (QRR) e é obtida considerando o tempo de vida útil dos ativos em relação à BRR.

Sendo assim, a remuneração total do capital apurada pelo processo da revisão tarifária é resultado do somatório: 
Quadro 4 - Remuneração total de capital

\begin{tabular}{|l|c|}
\hline \multicolumn{1}{|c|}{ ITEM } & FÓRMULA DE CÁLCULO \\
\hline 1) Remuneração do Investimento & $\begin{array}{c}\text { Taxa de Retorno x Base de Remuneração de Ativos } \\
(\text { BRR })\end{array}$ \\
\hline 2) Quota de Reintegração Regulatória & $\begin{array}{c}\text { Taxa de Depreciação x Base de Remuneração de Ativos } \\
\text { (BRR) }\end{array}$ \\
\hline Remuneração Total de Capital & 1) Remuneração do Investimento + 2) Quota de \\
& Reintegração Regulatória \\
\hline
\end{tabular}

Fonte: Nota técnica no 262/2006-SRE/ ANEEL.

Conforme quadro acima, para o cálculo da remuneração total de capital é necessário definir os seguintes parâmetros:
a) Base de Remuneração Regulatória - BRR;
b) taxa de retorno;
c) taxa de depreciação.

Também é possível observar que os dois componentes da remuneração total do capital têm como base de incidência a BRR. Essa base corresponde ao valor dos ativos prudentes necessários para prestação do serviço de distribuição de energia elétrica e está definida nos termos da Resolução Aneel 493, de 03/09/2002, e da Nota Técnica 178/2003-SFF/SRE/ ANEEL.

A taxa de remuneração adotada é única para todas as distribuidoras e refere-se ao custo de oportunidade para investimentos de risco semelhante. Corresponde à taxa de retorno adequada para a remuneração do capital investido.

A metodologia utilizada pela Aneel para estimação da taxa de retorno está apresentada nas Notas Técnicas nº 164/2006 e 60/2007 e consiste no cálculo do custo médio ponderado do capital - Weighted Average Cost of Capital - WACC, onde o custo regulatório do capital é o resultado da média ponderada dos custos de capital próprio e de terceiros.

A taxa de depreciação utilizada para cálculo da Quota de Reintegração Regulatória é uma taxa anual média de depreciação que considera os percentuais definidos para os bens do ativo imobilizado em serviço fixados pela Resolução Aneel $n^{-0}$ 240, de 05/12/2006, que estabelece a equalização das taxas anuais de depreciação para os ativos de uso e características semelhantes no âmbito da distribuição e da transmissão de energia elétrica. 
O uso desse critério é justificado pelo tratamento uniforme para todas as distribuidoras, eliminando a subjetividade do avaliador na determinação da vida útil remanescente do ativo e facilitando a realização de fiscalização e auditoria.

Sendo assim, a Quota de Reintegração Regulatória é resultado da aplicação de um percentual sobre a base de ativos valorada a custo de reposição e representa a forma de recomposição dos investimentos realizados para prestação do serviço ao longo da vida útil dos bens considerados.

Da equação da remuneração total de capital acrescida dos custos operacionais inseridos nas tarifas deve surgir o interesse privado na realização de novos investimentos na área e o equilíbrio econômico-financeiro dos contratos de concessão do setor elétrico, dado que os outros componentes são apenas repasse de custos.

Os componentes do cálculo da remuneração total de capital estão detalhados nos tópicos a seguir.

\subsection{Base de Remuneração Regulatória}

Como apresentado no tópico anterior, os dois componentes da remuneração de capital tem como base de incidência a Base de Remuneração Regulatória - BRR, composta pelos ativos em serviço avaliados no processo de revisão tarifária.

Em 2002, a Aneel colocou em audiência pública (AP 005/2002) a metodologia e os critérios gerais para definição da base de remuneração, com vistas à aplicação no primeiro ciclo de revisão tarifária periódica das distribuidoras de distribuição de energia elétrica (20032007). A metodologia está descrita na Nota Técnica $n^{0}$ 182/2002/SFF/ANEEL e foi aprovada pela Resolução Aneel 493/2002.

A determinação racional e previsível da base de remuneração é de suma importância para a preservação do equilíbrio econômico-financeiro dos contratos de concessão e também visa proteger, em última instância, os consumidores da imposição de custos injustos (Nota Técnica 353/2008-SFF/ANEEL).

Segundo a Resolução Aneel no 493/2002, que estabelece a metodologia de cálculo da BRR, para o montante de investimento a ser remunerado considera-se o valor dos ativos necessários à prestação dos serviços de distribuição de energia elétrica, avaliados a custo de reposição:

A base de remuneração é composta pelos ativos imobilizados em serviço, vinculados à concessão do serviço público de distribuição de energia elétrica, acrescida do almoxarifado de operação, vinculado à operação e manutenção de máquinas, 
instalações e equipamentos necessários à prestação do serviço público de distribuição de energia elétrica, do ativo diferido vinculado à prestação do serviço público de distribuição de energia elétrica, deduzida a respectiva amortização (Resolução n⿳0 493/2002, com alteração da Resolução 234/2006).

Para delimitar a inclusão de quaisquer bens na base de remuneração, a Aneel esclarece que os ativos que a comporão são aqueles vinculados aos investimentos necessários para manutenção do serviço:

[..] O conceito chave da Resolução 493/2002 é refletir apenas os investimentos prudentes na definição das tarifas dos consumidores. Trata-se dos investimentos requeridos para que a distribuidora possa prestar os serviços de distribuição cumprindo as condições do contrato de concessão (em particular os níveis de qualidade exigidos), avaliados a "preços de mercado" e "adaptados" através de índices de aproveitamento definidos na referida Resolução [...] (ANEEL, Nota Técnica 041/2003-SFF/ANEEL).

A Resolução ANEEL 493/2002 estabeleceu a metodologia de cálculo para a avaliação desses ativos. Segundo ela, o método a ser adotado é o custo de reposição ou substituição, cuja definição do regulador é a seguinte:

Através deste método, determina-se o valor de um ativo a partir do associado à sua reposição por outro que permite cumprir com as mesmas funções e qualidade de serviço, embora não necessariamente de idênticas características. Este método avalia os ativos levando em conta a melhor tecnologia disponível e os preços de mercado, os quais não necessariamente apresentam evolução de custos segundo os índices inflacionários (ANEEL, Nota Técnica 178/2002-SFF/ANEEL).

Por esse método um ativo é avaliado pelo custo corrente para substituí-lo por outro que efetue os mesmos serviços e tenha a mesma capacidade do ativo existente (ANEEL, Nota Técnica 178/2002- SFF/ANEEL).

Nos documentos disponíveis para as revisões tarifárias afirma-se que no processo de regulação adotado pela Aneel, a base do ativo deve refletir o valor de mercado do negócio regulado em qualquer ponto no tempo e o valor de mercado dos ativos não deve se situar em níveis inferiores à base do ativo regulado ao longo do tempo.

$\mathrm{Na}$ prática, a avaliação de ativos estabelecida pela Aneel ocorre por meio do credenciamento de algumas entidades avaliadoras de ativos, dentre as quais a distribuidora escolhe uma que fica incumbida de apresentar um laudo de avaliação conforme as regras estabelecidas pela Resolução 493/2002.

Todo esse processo nasce na contabilidade regulatória de onde são retirados os inventários físicos dos bens concedidos e o valor dos investimentos realizados, por meio do controle patrimonial realizado de acordo com o estabelecido no Manual de Contabilidade do Serviço Público de Energia Elétrica. 
$\mathrm{Na}$ metodologia do custo de reposição, considera-se o valor novo de reposição do ativo como base para a determinação do seu valor de mercado em uso. Apenas os grupos de ativos com maior significância em termos de valor, mais especificamente terrenos, edificações, obras civis e benfeitorias e máquinas e equipamentos serão avaliados pelo seu valor de mercado.

Para os demais ativos será admitida a avaliação expedita ${ }^{53}$, a partir da atualização de valores contábeis e mediante amostragem aleatória. Para os ativos vinculados aos grupos de contas Veículos e Móveis e Utensílios e, ainda, para os equipamentos de medição (medidores) será admitida a avaliação pelo método expedito a partir da atualização de valores contábeis.

A abordagem adotada no primeiro ciclo de revisões tarifárias, iniciado em 2003, para avaliar a base de ativos foi o Custo de Reposição Otimizado. Segundo a Nota Técnica 178/2003-SFF/ANEEL, esse processo envolveu os seguintes passos:

a) inventário de todos os ativos, com a devida conciliação físico-contábil;

b) valoração dos ativos pelo seu custo de reposição;

c) dedução da depreciação acumulada a partir das taxas contábeis definidas regulatoriamente;

d) dedução de parcela não aproveitada dos ativos, a partir de um índice de aproveitamento.

Ao utilizar o método do custo de reposição, o órgão regulador brasileiro aponta como principal vantagem a obtenção de uma aproximação razoável do valor que se deveria desembolsar para obter um ativo igual ou equivalente àquele objeto de avaliação, inclusive considerando os avanços tecnológicos. Argumenta também que ao determinar o preço do ativo no mercado, sendo esse valor o investimento que deve ser remunerado via tarifa, garantirá a continuidade das operações da empresa e, consequentemente, da prestação do serviço de energia elétrica.

Justifica ainda que a adoção desse método propicia a existência de um ambiente de mercado, mesmo se tratando de um monopólio regulado, condição essencial para a entrada de novos investidores, definição de tarifas justas e prestação do serviço com qualidade.

\footnotetext{
53 Segundo definido na norma NBR 5676/90 da ABNT, “Avaliação expedita é aquela que se louva em informações e/ou escolha arbitrária do engenheiro de avaliações, sem se pautar por metodologia definida nesta Norma e sem comprovação expressa dos elementos ou critérios que levaram à convicção do valor".
} 
Os pontos positivos apresentados pelo regulador encontram base na literatura. Cita-se Bonbright, Danielson e Kamerschen (1988): “o que se mede com o custo de reposição é o mesmo valor que hoje se despenderia para obter um ativo com a mesma capacidade".

Segundo Bragança e Camacho (2007), esse método identifica a distribuição de custos e o valor de ativos com maior precisão que os demais. Como resultado, o método do valor de reposição é julgado mais pertinente que o do valor histórico em ambientes regulados.

No entanto, também se observam desvantagens nesse método indicado por Bonbright, Danielson e Kamerschen (1988). O custo de reposição torna-se subjetivo e de difícil aplicação na avaliação de ativos cujos custos de substituição sejam vagos ou que requeiram conjectura significativa com respeito à identificação do melhor substituto disponível. Isto ocorre especialmente nos casos de entidades públicas com ativos incomuns.

Esse ponto merece destaque, pois mesmo a metodologia encontrando bases na literatura, pode encontrar sérios obstáculos na sua aplicação prática. Visando demonstrar esse viés, apresenta-se uma tabela com a retrospectiva de 2003 a 2007 com o total de empresas que passaram pelo processo de revisão, destacando as que tiveram seu laudo de avaliação de ativos pelo custo de reposição aprovados pela Aneel.

Quadro 5 - Total de empresas de distribuição com aprovação da base de ativos

\begin{tabular}{|l|r|r|r|r|r|}
\hline & \multicolumn{4}{c|}{ Primeiro Ciclo } & \multicolumn{1}{|c|}{ Segundo Ciclo } \\
\hline \hline & 2003 & 2004 & 2005 & 2006 & 2007 \\
\hline \hline Total & 17 & 27 & 16 & 1 & 7 \\
\hline Aprovadas & 0 & 4 & 13 & 1 & 5 \\
\hline \hline
\end{tabular}

Em 2003 e 2004 a maioria das empresas que passaram pelo processo de avaliação de ativos pelo método do custo de reposição não tiveram seus valores aprovados. De um total de quarenta e quatro empresas, apenas quatro tiveram suas bases de ativos aprovadas. Somente a partir de 2005, nota-se uma melhora no indicador.

Para essa situação as justificativas apresentadas foram:

a) na avaliação de terrenos foram constatadas diversas dificuldades para realização dos trabalhos (por exemplo: encontrar amostras compatíveis com o terreno avaliado, principalmente em cidades pequenas; problemas de transparência apresentados durante os trabalhos de fiscalização); 
b) na avaliação de máquinas e equipamentos ocorreram problemas de documentação, cotações e informações insuficientes e pouco detalhadas, dificultando a validação da base;

c) na avaliação de usinas hidrelétricas ocorreram problemas de documentação e informações insuficientes e pouco detalhadas, que não permitiram a reprodução dos projetos das usinas por meio de orçamentos confiáveis e que não apresentassem distorções relevantes.

Esse retrospecto e as justificativas apresentadas evidenciam a dificuldade de se avaliar ativos a custos de reposição ${ }^{54}$.

O processo de avaliação de ativos regulatórios é tema de constante discussão entre os agentes. O caso da Enersul citado no tópico 3.2.1 deste capítulo mostra que o processo ainda não está consolidado e causa prejuízos aos consumidores.

Em 2006, para o segundo ciclo de revisão tarifária a Aneel colocou em audiência pública (AP 008/2006) proposta de alteração na metodologia de cálculo para base de remuneração regulatória aprovada pela Resolução 493/2002.

As alterações foram aprovadas pela Resolução Aneel 234/2006, onde se previu que a base de ativos estabelecida para o primeiro ciclo de revisões não deverá passar novamente por avaliação, de modo que os valores associados a esses ativos deverão ser atualizados pelo Índice Geral de Preços de Mercado (IGP-M).

Adicionalmente, os ativos que chegaram ao fim da vida útil ao longo do primeiro ciclo devem ser retirados da base, evitando assim o retorno de capital e remuneração indevidos. Passa-se a chamar a base de ativos avaliada no primeiro ciclo de "base blindada." Essa blindagem envolve a não reavaliação desses ativos, tanto nas quantidades quanto nos preços. A atualização dos preços se dará apenas pela aplicação do índice IGP-M sobre a base de ativos avaliada no primeiro ciclo.

Da mesma forma, a Resolução 234/2006 disciplinou como deveriam ser tratados os novos ativos correspondentes a investimentos realizados após a avaliação do primeiro ciclo, ou seja, a base de ativos incremental ${ }^{55}$. Em linhas gerais, a Resolução determina que os ativos incrementais sejam avaliados por meio de processo semelhante ao aplicado para a definição

\footnotetext{
${ }^{54}$ Não havendo a aprovação do laudo de avaliação, a Aneel define uma base de remuneração provisória com base no custo histórico corrigido.

${ }^{55}$ Os novos ativos que entram em operação entre a primeira e segunda revisão tarifária, são chamados de "base incremental" (Nota Técnica 547/2008-SFF/ANEEL).
} 
da base de ativos do primeiro ciclo, diferenciando-se apenas quanto ao método de precificação cuja referência seria um banco de preços a ser construído pela Aneel.

Durante o ano de 2007 foram fixados pela metodologia estabelecida na citada Resolução valores definitivos de BRR de 5 empresas das 7 que passaram pelo processo de revisão tarifária.

Contudo, no final de 2007, foi colocada em audiência pública (AP 052/2007) a Nota Técnica 353/2007-SRE/SFF, que tem como objetivo:

[...]. apresentar os aperfeiçoamentos da metodologia e critérios gerais para definição da base de remuneração, visando à revisão tarifária periódica das distribuidoras de energia elétrica, estabelecidos pela Resolução Aneel n. ${ }^{\circ}$ 234, de 31 de outubro de 2006.

Inclui-se nesse conteúdo a alteração na forma de valoração dos ativos da base incremental, que são aqueles realizados durante o ciclo tarifário.

As alterações trazidas pela Resolução 234/2006 estabelecem que os ativos da base incremental serão avaliados pelo custo de reposição com base em valores de um banco de preços da Aneel $^{56}$. O desenvolvimento do referido banco de preços não aconteceu e o que foi adotado em 2007 foi o banco de preços da própria distribuidora.

A Nota Técnica 353/2007-SRE/SFF-ANEEL propõe alteração da utilização do banco de preços da Aneel para o método do custo histórico atualizado para valoração dos ativos referentes à base incremental.

Segundo Evans (2000), o uso de custos históricos em um regime regulatório pode permitir aos investidores retornos adequados sobre os seus investimentos desde que a metodologia seja aplicada de maneira consistente ao longo da vida dos ativos.

Lallly (2002) apresenta como principal vantagem de usar um enfoque baseado em custos históricos sua fundamentação em dados razoavelmente objetivos que podem ser auditados por partes independentes e, portanto, são relativamente robustos à manipulação.

Entretanto, algumas desvantagens do custo histórico atualizado também devem ser apontadas. O enfoque histórico pode também incentivar os investidores a manter ativos redundantes ou superdimensionados na base de ativos de forma a continuar a ter retorno sobre

\footnotetext{
${ }^{56}$ As dificuldades para construção do banco de preços Aneel foram apresentadas na Nota Técnica 353/2007, quais sejam: composição de estruturas modulares, necessidade de levantamento de notas fiscais de forma a compor os preços médios e regionalizados, e tempo de execução - sua implementação demandaria um tempo inexequível de aplicação ainda no segundo ciclo de revisões, comprometendo todo esforço de aperfeiçoamento metodológico.
} 
eles. Revisões periódicas da eficiência da base de ativos, com uma visão sobre otimização destes ativos, podem ajudar a resolver esse problema.

Uma desvantagem é o chamado efeito Averch-Johnson ${ }^{57}$ - onde se uma firma que tem como objetivo a maximização de lucros está sujeita à regulação por custo de serviço (isto é, sua taxa de retorno sobre o investimento é fixa e, portanto, seus lucros são proporcionais à base de capital) tenderá a usar mais tecnologias capital-intensivas para aumentar a base de capital.

Quanto aos critérios estabelecidos na Nota Técnica 353/2007, para atualização da base incremental, observa-se a proposta de utilização do custo histórico atualizado com índices específicos $^{58}$ dependendo do tipo de ativo e para a base blindada (aquela avaliada no primeiro ciclo tarifário) atualização via índice geral de preços de mercado - IGPM.

A blindagem da base de ativos do primeiro ciclo significa que os bens auditados e corrigidos pelo IGPM são um ativo financeiro. Nesse sentido, o critério adotado demonstra a preocupação em sinalizar uma estabilidade regulatória.

No entanto, a audiência pública não foi aprovada com rapidez, e a Aneel sem ter o seu "banco de preços" continuou utilizando o banco de preços individual, ou seja, o da distribuidora, durante o ano de 2008.

Em novembro de 2008, a Aneel publicou Nota Técnica 547/SFF/ANEEL, onde resolve pela manutenção do método definido na Resolução n. ${ }^{\circ}$ 234/2006, ou seja, pelo custo de reposição, adequando-se, no entanto, a referida resolução para incorporar a utilização do banco de preços individuais e não mais o de preços médios regionais também para a base incremental, considerando que até 30 de setembro de 2008 já haviam sido realizadas 40 revisões tarifárias, sendo que em 35 delas a aprovação da base de remuneração ocorrera em caráter definitivo e que, portanto, a alteração na metodologia afetaria apenas em torno de $30 \%$

\footnotetext{
${ }^{57} \mathrm{O}$ artigo que trata desse efeito é o Behavior of the Firm Under Regulatory Constraint, dos autores Averch e Johnson (1962). O "Efeito Averch-Johnson" diz que se uma firma que maximiza lucros está sujeita à regulação por custo de serviço (ex.: sua taxa de retorno sobre o investimento é fixa e, portanto, seus lucros são proporcionais à Base de Capital), ela tenderá a usar tecnologias mais capital intensivas do que seria socialmente ótimo, para aumentar a Base de Capital.

${ }^{58}$ Segundo a Nota Técnica 353/2007-SFF/SRE/ANEEL, para atualização e/ou retroação dos valores apurados na avaliação devem ser utilizados: i) para edificações, o Índice Nacional de Construção Civil - INCC, coluna 35, apurado pela Fundação Getúlio Vargas; ii) para máquinas e equipamentos, os índices Indústria de Transformação - Material Elétrico - Motores e Geradores, coluna 40 (para Transformadores de Força, Transformadores de Distribuição e Transformadores de Serviços Auxiliares) e Indústria de Transformação - Material Elétrico Outros, coluna 41 (para demais equipamentos de máquinas e equipamentos), apurados pela Fundação Getúlio Vargas; iii) para terrenos, servidões, móveis e utensílios e veículos, o Índice de Preços ao Consumidor Amplo IPCA, apurado pelo IBGE.
} 
das 61 distribuidoras e considerando, ainda, que o modelo em uso (banco de preços individuais) mostrou-se uma alternativa viável.

Por fim, ao considerar os procedimentos dos ciclos tarifários, ressalta-se o declarado por Lally (2002): "não há um único método de avaliação que é apropriado para todas as circunstâncias, nem está inequivocadamente preferida a escolha de um método de avaliação ou outro para situação específica".

A incerteza de não ter os valores da base de ativos aprovada gera desconfiança no mercado, como pode ser observado pela reportagem do Jornal Valor Econômico, de 02/03/2005, que demonstra a reação do mercado diante da não aprovação da base de ativos e seu impacto na estrutura de capital da empresa:

\footnotetext{
Como algumas empresas ainda não tiveram sua base de ativos fixada definitivamente, enfrentam dificuldade para ir a mercado captar recursos, só tendo acesso às operações mais caras.

Entre as que ainda se encontram com base provisória estão a Eletropaulo, CPFL, Cemig, Elektro, Bandeirantes, Piratininga, CEEE, Energipe, Coelce, Coelba e Escelsa, só para citar as que atendem aos maiores mercados. Segundo a Associação Brasileira de Distribuidoras de Energia Elétrica (Abradee), analistas de bancos informaram que o custo médio de captação dessas empresas aumentou entre $1 \% \mathrm{e}$ $2 \%$ ao ano. Pedro Batista, do Banco Pactual, confirma, sem citar nomes de empresas. [...] A falta de uma base definitiva está tirando a previsibilidade da tarifa dessas companhias, reduzindo sua capacidade de fazer dívida. E quem perde margem de distribuição perde capacidade de investir, de prestar serviços de qualidade e de remunerar os acionistas e os detentores da dívida, diz o analista (VALOR ECONÔMICO, 2005).
}

Observa-se que para o segundo ciclo, iniciado em 2007, já foram aprovadas de forma definitiva mais de $50 \%$ de bases de remuneração avaliadas. Para esse ciclo foram feitas alterações em relação ao procedimento de avaliação, onde, ao invés de cotação de preços, passa-se a utilizar o banco de preços referenciados da Aneel para a base incremental.

Ressalta-se que ao utilizar o banco de preços individuais, este considera os efetivos valores praticados pelas distribuidoras no mercado específico do setor elétrico, os tipos e as características dos equipamentos a serem avaliados.

Nesse sentido, demonstra-se a busca por uma estabilidade regulatória, reforçada pela busca de soluções quanto à subjetividade inerente ao método do custo de reposição, para que as bases de ativos aprovadas tenham em seus valores coerência com os valores dos ativos específicos do setor elétrico. 


\subsection{Taxa de Retorno - Custo Médio Ponderado de Capital}

No ano de 2003, no início do primeiro ciclo tarifário, a Aneel colocou em audiência pública, por meio da Nota Técnica n $236 / 2003 /$ SRE/ANEEL, modelo para cálculo da taxa de retorno a ser utilizada como custo de capital para as empresas de distribuição de energia elétrica.

Para o segundo ciclo tarifário, iniciado em 2007, a metodologia está descrita nas Notas Técnicas no $\underline{\text { os }}$ 164/2006 e 68/2007, cujo conteúdo foi consolidado pela Resolução Aneel no 234/2006, alterada pela Resolução Aneel 246/2006 e pela Resolução Aneel259/2007.

A metodologia utilizada nos dois ciclos tarifários é conceitualmente a mesma, portanto, descreve-se a seguir apenas o conteúdo das notas aplicáveis ao segundo ciclo de revisão tarifária periódica. São elas: Nota Técnica nos 164/2006-SRE/ANEEL, 262/2006SRE/ANEEL e 68/2007-SRE/ANEEL.

Conforme previsto na Nota Técnica 164/2006, a remuneração total do capital dependerá da definição da base de remuneração regulatória e da taxa de retorno a ser aplicada sobre essa base, representando essa taxa o custo de oportunidade do capital.

O custo do capital pode ser considerado como o custo econômico que o negócio, no caso o serviço público de distribuição de energia elétrica, tem para atrair novo capital e reter o capital existente.

De acordo com a Nota Técnica 164/2006, para definição da taxa de retorno é cada vez maior o consenso para adoção de métodos padronizados ${ }^{59}$ (aqueles cuja definição está dada por fórmulas matemáticas cujas variáveis são claramente explicitadas), fazendo com que a determinação da taxa de maneira fixa ou arbitrária seja cada vez menos utilizada. Dessa maneira, a observação de regras claras e transparentes objetiva elevar a concorrência pelos fluxos de aplicações, assim como a segurança da indústria.

Como fonte de argumentação a Nota Técnica apresenta a experiência internacional comparativa (modelos da Inglaterra, Argentina, Austrália e Espanha para o setor de distribuição de energia elétrica) a ser aproveitada para conduzir melhorias na regulação econômica, assim como para a elaboração de novas propostas sobre a matéria.

Entre os métodos padronizados, segundo a Aneel, o que maior consenso adquiriu é o "Weighted Average Cost of Capital" em combinação com o "Capital Asset Princing Model" (CAPM/WACC).

\footnotetext{
${ }^{59}$ Os métodos padronizados promovem transparência e oferecem maior certeza sobre quais são os elementos determinantes da taxa de retorno e como a influenciam.
} 
Para Damodaran (2004, p. 77), o WACC, ou custo médio ponderado de capital, pode ser definido como "a média ponderada dos custos dos diversos componentes de financiamento, incluindo dívida, patrimônio líquido e títulos híbridos, utilizados por uma empresa para financiar suas necessidades financeiras.

O WACC adotado pela Aneel segundo a Nota Técnica 164/2006, procura refletir o custo médio das diferentes alternativas de financiamento (capital próprio e de terceiros) disponíveis para o empreendimento. O modelo utilizado é representado pela seguinte fórmula:

$$
r_{W A C C}=\frac{P}{P+D} \cdot r_{P}+\frac{D}{P+D} \cdot r_{D} \cdot(1-T)
$$

Onde:

$\mathrm{r}_{\mathrm{wacc}}$ : custo médio ponderado de capital (taxa de retorno);

r: custo do capital próprio;

$\mathrm{r}_{\mathrm{D}}$ : custo da dívida;

P: capital próprio;

D: capital de terceiros ou dívida;

T: alíquota tributária marginal efetiva.

Observa-se que para determinar o WACC é necessário determinar a estrutura de capital, apurando-se as proporções entre os tipos de capital (próprio e de terceiros), os custos do capital próprio e de terceiros e os tributos aplicáveis. Os valores referentes à estrutura de capital são valores contábeis.

No caso da alíquota tributária aplicada na formula do WACC regulatório a Nota Técnica n 302/2006 - SRE/ANEEL registra que alguns reguladores, como os do Reino Unido, determinam a taxa de retorno antes dos tributos. Outros reguladores, como os da Argentina, calculam a taxa de retorno líquida após os tributos. É possível ainda fazer um caso intermediário, computando a taxa de retorno líquida com alguns tributos antes e outros após. Isso pode ser útil no caso de tributos cuja alíquota é determinada a posteriori, levando em consideração receitas e despesas não conhecidas pelo regulador, como, por exemplo, os impostos sobre a renda. Nesse caso, os impostos sobre a renda são deixados de fora do cálculo da taxa de retorno. 
Apresenta a nota citada acima que do ponto de vista do potencial investidor no setor de energia elétrica o que interessa é a taxa de retorno líquida após todos os juros e tributos pagos e por essa razão adota-se a utilização da taxa de retorno após os impostos.

Quanto à alíquota a ser utilizada apresenta que de acordo com a legislação vigente, Lei $\mathrm{n}^{\circ}$ 9.249/95 e posteriores, há duas alíquotas: de $15 \%$ (quinze por cento) incidente sobre a parcela do lucro real, presumido ou arbitrado de até $\mathrm{R} \$ 240.000,00$ e a adicional de $10 \%$ (dez por cento) incidente sobre a parcela que exceder a $\mathrm{R} \$ 240.000,00$. Nesse sentido, ao observar que os negócios em distribuição de energia elétrica são de grande volume de investimento, sugere que a alíquota de incidência do IRPJ resultante esteja muito próxima do valor máximo de $25 \%$ (vinte e cinco por cento), justificando assim a adoção de uma alíquota única para simplificação dos cálculos.

Em relação à CSLL, considerando o que determina a legislação ${ }^{60}$, uma alíquota de $8 \%$ (oito por cento) incidente sobre os fatos geradores ocorridos a partir de $1^{\circ}$ de janeiro de 1999 , considerado um adicional de $4 \%$ (quatro pontos percentuais), quando tais fatos ocorrerem de $1^{\circ}$ de maio de 1999 a 31 de janeiro de 2000, num total de $12 \%$ (doze por cento), ou adicional de $1 \%$ (um ponto percentual), quando ocorridos de $1^{\circ}$ de fevereiro de 2000 a 31 de dezembro de 2002, adota especificamente para as distribuidoras um total fixo de $9 \%$ (nove por cento).

Considerando o que dispõe essa nota técnica, a alíquota de impostos ( $\mathrm{T}$ ) a ser considerada na fórmula do WACC regulatório é de $34 \%$.

A metodologia utilizada para o cálculo da estrutura ótima de capital das distribuidoras para o segundo ciclo de revisão tarifária foi estabelecida na Resolução Aneel no 234/2006 está descrita na Nota Técnica 262/2006-SRE/ANEEL.

A determinação da estrutura ótima de capital baseia-se em dados empíricos das empresas de distribuição de energia elétrica dos seguintes países que utilizam o regime regulatório de preços máximos: Argentina, Chile, Brasil, Austrália e Grã-Bretanha ${ }^{61}$. A partir

${ }^{60}$ Medida Provisória 2.158-34, de 27.7.2001, arts. $6^{\circ}$ e $7^{\circ}$.

${ }^{61}$ Em termos gerais, primeiramente agrupa-se os cinco países em três grupos. O primeiro grupo de países, chamado de grupo 1, é formado por Argentina e Chile. A razão para o agrupamento desses dois é que ambos são países em desenvolvimento, cujas empresas de distribuição de eletricidade estão sujeitas à regulação de price cap. Posteriormente, agrupam-se a Austrália e a Grã-Bretanha, países com alto grau de desenvolvimento e que aplicam a regulação de price cap no setor de distribuição de eletricidade, que é chamado de grupo 2. Finalmente, forma-se o grupo 3, contendo apenas as empresas brasileiras de distribuição de energia elétrica. Após a formação dos três grupos, determina-se uma faixa de valores da relação capital de terceiros/capital total (relação D/V) para cada país a partir da observação empírica das empresas nos respectivos países. Em seguida, procede-se à formação de uma faixa de valores da relação $\mathrm{D} / \mathrm{V}$ para cada grupo. $\mathrm{O}$ passo seguinte combina as faixas dos grupos (1 e 2), obtendo-se uma outra faixa que servirá de comparação com a que resulta dos dados brasileiros (grupo 3). O período analisado foi de 1998 a 2002. 
da análise da relação capital de terceiros/capital total (relação $\mathrm{D} / \mathrm{V}^{62}$ ) dessas empresas, é obtida a estrutura ótima de capital para as distribuidoras brasileiras de energia elétrica. $\mathrm{O}$ valor resultante da aplicação da metodologia foi de $42,84 \%$ de participação de capital próprio e $57,16 \%$ de capital de terceiros.

O custo de capital próprio é a taxa de retorno que um investidor requer para investir seu capital em uma empresa associada a uma determinada atividade. Este retorno deve incluir todos os dividendos, assim como qualquer perda ou ganho de capital. Existem diversos métodos para estimar o custo do capital próprio, dentre os quais podem ser destacados os seguintes: Capital Asset Pricing Model (CAPM) ${ }^{63}$, Arbitrage Pricing Theory $(\mathrm{APT})^{64} \mathrm{e}$ Dividend Growth Model (DGM) ${ }^{65}$.

Para o custo de capital próprio, a Aneel adota o método CAPM. Esse método assume que o prêmio de risco requerido pela ação é proporcional ao seu coeficiente beta, o qual mede a volatilidade e indica a covariância dos retornos da ação de uma determinada empresa em relação ao comportamento do mercado acionário.

O modelo de estimação do custo do capital próprio pelo método CAPM utilizado pela Aneel encontra-se expresso na fórmula a seguir:

$$
r_{C A P M}=r_{f}+\beta_{d}\left(r_{m}-r_{f}\right)+r_{r}
$$

Onde:

$r_{C A P M}$ : custo de capital próprio;

$r_{f}:$ taxa de retorno do ativo livre de risco;

$\beta$ : beta do setor regulado;

$r_{m}-r_{f}$ : prêmio de risco do mercado de referência;

$r_{r}$ : outros prêmios de risco

Para considerar os outros prêmios de risco, como se deseja determinar o custo de capital para uma indústria regulada no Brasil, são incorporados prêmios de risco adicionais, associados às especificidades do mercado local. Desse modo, ao CAPM padrão adicionam-se

\footnotetext{
${ }^{62} \mathrm{O}$ símbolo "V" apresentado pela Aneel refere-se ao Patrimônio Total.

${ }_{64}^{63}$ Esse modelo de precificação de ativos, o CAPM, foi introduzido inicialmente em 1964 por William F. Sharpe.

${ }^{64}$ ROSS, S. A. The arbitrage theory of capital asset pricing. Journal of Economic Theory, Dec. 1976. Encontrado também em ROSS, S. A.; WESTERFIELD, R. W.; JAFFE, F. J. Administração Financeira. 2.ed. São Paulo: Atlas, 2002.

${ }^{65}$ Esse modelo, o DGM, foi proposto inicialmente por Gordon em GORDON, M. The investment, financing, and valuation of the corporation. Irwin, Homewood, IL, 1962.
} 
o prêmio de risco Brasil $\left(\mathrm{r}_{\mathrm{B}}\right)$, o prêmio de risco cambial $\left(\mathrm{r}_{\mathrm{x}}\right)$ e, dependendo da indústria em análise e do mercado de referência, o prêmio de risco de regime regulatório $\left(\mathrm{r}_{\mathrm{R}}\right)$. A expressão do custo de capital próprio torna-se então:

$$
r_{C A P M}=r_{f}+\beta \cdot\left(r_{m}-r_{f}\right)+r_{B}+r_{X}+r_{R}
$$

Para taxa livre de risco $\left(\mathrm{r}_{f}\right)$ utiliza-se o rendimento do bônus do tesouro americano com vencimento de 10 anos.

Segundo a Nota Técnica 068/2007-SRE/ANEEL, o prêmio de risco de mercado mede a diferença entre o retorno esperado no mercado acionário (investimento com risco) e o retorno de títulos livre de risco. Para se estimar o prêmio de risco de mercado, subtrai-se a taxa livre de risco do retorno médio anual da série histórica dos retornos do portfólio do mercado de referência. No caso de se usar os Estados Unidos como mercado de referência, uma boa proxy de um portfólio de mercado é o S\&P500, que consiste em um índice composto pelas ações das 500 maiores empresas negociadas na Bolsa de Nova York. O período de tempo (momento inicial e final) considerado na determinação dos dados históricos utilizados é determinante sobre os resultados obtidos.

$\mathrm{Na}$ determinação da taxa de prêmio por risco através da utilização de valores históricos, assume-se implicitamente que o retorno médio realizado é uma proxy apropriada dos retornos esperados (ou seja, os valores passados contém informação suficiente a respeito das expectativas futuras dos investidores).

Para a estimação do prêmio por risco do mercado são considerados dois aspectos importantes: o período que será tomado como referência e a técnica estatística utilizada para o cálculo das médias. É utilizada a média aritmética com argumento de que é a metodologia que melhor reflete o prêmio exigido pelo investidor, uma vez que captura de forma independente o retorno médio anual histórico obtido pelo investidor sem atribuir ponderações a qualquer evento, seja ele extremamente positivo ou extremamente negativo, e que ainda essa média também captura a volatilidade apresentada pelo retorno das ações ao longo de todo o período histórico, sendo essa a principal variável na determinação do retorno exigido pelo investidor.

Considerando esses parâmetros e com base nas séries históricas de 1928 a 2006, foi determinada a série mensal do retorno do mercado ("excedente") como resultado da diferença entre a taxa de retorno do mercado acionário (S\&P500) e a taxa livre de risco, obtendo uma 
taxa anual média (aritmética) de retorno do mercado acionário americano de 6,09\% a.a., a ser utilizada no cálculo do custo de capital para o segundo ciclo de revisão tarifária periódica.

Segundo a Nota Técnica 068/2007- SRE/ANEEL, o beta ${ }^{66}$ é medida de risco de um título em uma carteira ampla e significa o quanto esse título deverá variar quando o mercado variar de uma unidade percentual, ou seja, é a sensibilidade das ações às variações percentuais do valor da carteira de mercado. Para o cálculo do beta, considera-se que este reflete os diversos tipos de risco: o risco do negócio e o risco financeiro. O risco do negócio pode ser definido como o grau de incerteza em relação à projeção do retorno sobre o ativo total inerente ao negócio, que não pode ser eliminado por diversificação. $\mathrm{O}$ risco financeiro é o risco adicional devido ao uso de capital de terceiros no financiamento do projeto, isto é, o risco adicionado ao projeto devido à alavancagem financeira.

Para o cálculo do prêmio de risco país, a Aneel por meio da Nota Técnica 068/2007SRE/ANEEL apresenta que o risco país é entendido como o risco adicional que um projeto incorre ao ser desenvolvido em um determinado país de economia emergente (mercado doméstico) quanto ao cumprimento ou não do reembolso prometido pelo devedor soberano na data de vencimento dos títulos por ele emitidos, ou seja, o investidor está interessado em quanto deveria ser recompensado por aplicar em papéis que embutam certa possibilidade de default (não recebimento) em relação a um título de um país considerado como de risco "zero".

Para o cálculo do prêmio de risco cambial, a Aneel utilizou a metodologia de Wolff $(1997,2000)^{67}$. Nos termos dessa metodologia, o risco cambial é definido como a diferença entre o spread do câmbio no mercado futuro e a expectativa de desvalorização cambial, e a realização da desvalorização cambial é a expectativa de desvalorização adicionada de um "Ruído Branco"68. Assim, aplica-se um procedimento estatístico (filtro de Kalman) para se eliminar o "Ruído Branco".

Para o cálculo do prêmio de risco do regime regulatório considera-se que o risco do regime regulatório dos EUA encontra-se refletido no beta daquele mercado. Contudo, é reconhecido que o regime de regulação por "preços máximos" apresenta maiores riscos que o

\footnotetext{
66 "O Beta mede a sensibilidade de um título a movimentos da carteira de mercado" (ROSS, 2007, p. 228).

67 WOLFF, C. C. P. Forward foreign exchange rates, expected spot rates, and premia: a signal-extraction approach. The Journal of Finance, v. 42, p. 395-406, 1997.; WOLFF, C. C. P. Measuring the exchange risk premium: multi-country evidence from unobserved components models. Journal of International Financial Markets, Institutions and Money, v. 10, p. 1-8, 2000.

${ }^{68}$ O Ruído Branco é um fator transitório atípico que tende a se dissipar ao longo do tempo. Na linguagem estatística, um processo estocástico é definido como Ruído Branco quando a média é nula e a variância constante.
} 
regime de regulação por taxa de retorno adotado nos EUA, de forma que se faz necessário determinar o risco adicional derivado do regime regulatório brasileiro.

Segundo a Aneel, uma maneira de estimar a diferença de risco existente entre os ambientes regulatórios distintos seria justamente pela diferença entre os betas. Para isso, existem duas possibilidades: a primeira seria considerar que esse maior risco regulatório envolve não só o risco de negócio como também de preços, e a segunda seria considerar somente o risco do negócio. A opção foi pela segunda possibilidade com o argumento de que é mais aderente aos princípios adotados para cálculo do custo de capital das distribuidoras. Dessa forma, o ajuste a um mercado price cap é feito somente para o risco do negócio, sem considerar a alavancagem financeira.

Para o custo de capital de terceiros adota-se atualmente uma abordagem similar à do capital próprio, ou seja, adiciona-se à taxa livre de risco os prêmios de risco adicionais exigidos para se emprestar recursos a uma distribuidora de distribuição no Brasil. A justificativa apresentada pela Aneel para adoção desse enfoque é que ele impede que as tarifas sejam afetadas por uma gestão financeira imprudente na captação de recursos de terceiros ou por decisões de captação de dívidas vinculadas a outros interesses.

O custo do capital de terceiros é calculado pelo método CAPM de dívida, conforme a seguinte expressão:

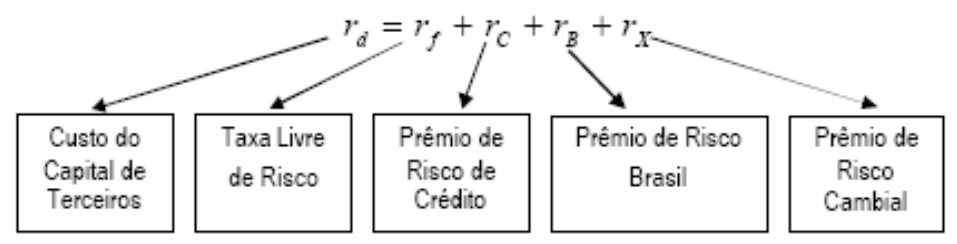

A estimação do custo de capital de terceiros tem como componentes a taxa livre de risco, o prêmio de risco de crédito, o prêmio de risco Brasil e o prêmio de risco cambial. Os critérios para o cálculo da taxa livre de risco e dos prêmios de risco Brasil e cambial já foram apresentados. Resta apresentar como apurar o prêmio de risco de crédito.

De acordo com a Nota técnica 68/2007-SRE/ANEEL, o prêmio de risco de crédito deve representar o spread acima da taxa livre de risco que pagam empresas com a mesma classificação de risco que as distribuidoras de energia elétrica brasileiras. Assim, adota-se como prêmio de risco de crédito a média dos prêmios de risco de crédito de empresas dos EUA que possuam a mesma classificação de risco das distribuidoras de energia elétrica brasileiras que tenham emitido títulos de longo prazo desde 1994 e que tenham liquidez ${ }^{69}$.

\footnotetext{
${ }^{69}$ A classificação de risco das distribuidoras de energia elétrica no Brasil será obtida da agência Moody’s.
} 
Seguindo a metodologia descrita acima, apurou-se que o custo de capital de terceiros é de $12,06 \%$, para o segundo ciclo tarifário, iniciado em 2007, conforme quadro abaixo:

Quadro 6 - Custo de capital de terceiros

\begin{tabular}{lc}
\hline \multicolumn{1}{c}{ Componente } & Prêmio \\
\hline Taxa livre de risco & $5,32 \%$ \\
\hline Prêmio de risco Brasil & $4,91 \%$ \\
\hline Prêmio de risco cambial & $1,78 \%$ \\
\hline Prêmio de risco de crédito & $2,96 \%$ \\
\hline Custo de Capital (nominal) & $14,97 \%$ \\
\hline Custo de Capital (real) & $12,06 \%$ \\
\hline
\end{tabular}

Fonte: Nota Técnica n⿳0 068/2007-SRE/ANEEL.

Depois de estabelecidos os parâmetros de cálculo do WACC e considerando que as tarifas são reajustadas por um índice de inflação (Índice Geral de Preços ao Mercado - IGPM) e que o custo de capital deve ser expresso em termos reais, deve-se descontar a taxa de inflação média anual dos EUA para se apurar a taxa WACC para as distribuidoras de energia elétrica do Brasil, de acordo com a expressão a seguir:

$$
r_{W A C C}^{r}=\frac{1+r_{W A O C}}{1+\pi}
$$

Onde:

$\boldsymbol{\Pi}=$ taxa de inflação.

De acordo com a metodologia descrita nos normativos emitidos pela Aneel, foram definidos os parâmetros de cálculo do custo médio ponderado de capital (WACC) para o primeiro e segundo ciclos tarifários, conforme tabela abaixo. 
Tabela 2 - Custo médio ponderado de capital

\begin{tabular}{|l|c|c|c|}
\hline & $\begin{array}{c}\text { 1 Ciclo } \\
\text { Tarifário }\end{array}$ & $\begin{array}{c}\text { 2 Ciclo } \\
\text { Tarifário }\end{array}$ & $\begin{array}{c}\text { 2 Ciclo Tarifário } \\
\text { (ajustado) }\end{array}$ \\
\hline Estrututa de Capital & & & \\
\hline Participação de Capital Próprio & $50,00 \%$ & $43,80 \%$ & $42,84 \%$ \\
\hline Participação de Capital de Terceiros & $50,00 \%$ & $56,20 \%$ & $57,16 \%$ \\
\hline Custo de Capital Próprio & & & \\
\hline Taxa livre de risco & $6,01 \%$ & $5,32 \%$ & $5,32 \%$ \\
\hline Prêmio risco de Mercado & $7,76 \%$ & $6,09 \%$ & $6,09 \%$ \\
\hline$\beta$ médio desalavancado & 0,15 & 0,273 & 0,296 \\
\hline$\beta$ médio alavancado & 0,26 & 0,497 & 0,554 \\
\hline Ajuste do Beta (regime regulatório) & & 0,240 & 0,218 \\
\hline Beta Final & & 0,737 & 0,772 \\
\hline $\begin{array}{l}\text { Prêmio risco do negócio, financeiro e } \\
\text { regulatório }\end{array}$ & $2,05 \%$ & $4,49 \%$ & $4,70 \%$ \\
\hline Prêmio risco Brasil & $4,08 \%$ & $4,91 \%$ & $4,91 \%$ \\
\hline Prêmio risco cambial & $2,00 \%$ & $1,78 \%$ & $1,78 \%$ \\
\hline Custo de Capital Próprio Nominal & $17,47 \%$ & $16,50 \%$ & $16,71 \%$ \\
\hline Custo de Capital Próprio Real & & $13,61 \%$ & $13,75 \%$ \\
\hline Custo de Capital de Terceiros & $15,76 \%$ & & \\
\hline Prêmio risco de crédito & & $2,96 \%$ & $2,96 \%$ \\
\hline Custo de dívida nominal & & $14,97 \%$ & $14,97 \%$ \\
\hline Custo de dívida real & & $12,12 \%$ & $12,06 \%$ \\
\hline Custo médio Ponderado & & & \\
\hline WACC nominal depois de impostos & $13,96 \%$ & $12,78 \%$ & $12,81 \%$ \\
\hline WACC real depois de impostos & $\mathbf{1 1 , 2 6 \%}$ & $\mathbf{9 , 9 8 \%}$ & $\mathbf{9 , 9 5 \%}$ \\
\hline IR + CSLL & $34,00 \%$ & $34,00 \%$ & $34,00 \%$ \\
\hline Fo N Na Técno & \\
\hline
\end{tabular}

Fonte: Nota Técnica nº 164/SRE/ANEEL; Resolução Aneel 246/2006 e 259/2007.

Como pode ser observado, do primeiro para o segundo ciclo tarifário houve ajustes no valor adotado como custo de capital para as distribuidoras. Os ajustes que foram realizados estão descritos na Nota Técnica 262/2006-SRE/ANEEL e estão resumidos a seguir:

a) no cálculo do prêmio de risco de mercado, tanto para a taxa de retorno de mercado quanto para a taxa livre de risco, a série histórica inicia-se em 1928. Para o cálculo da taxa livre de risco incluída diretamente no modelo CAPM é utilizada uma série histórica mais curta, visando à consideração de cenários econômicos mais recentes;

b) na estimativa dos betas das empresas americanas é utilizada uma janela temporal de 5 anos em bases mensais, com a série iniciando em julho de 2001 e terminando em junho de 2006;

c) no cálculo dos betas desalavancados é utilizada a alíquota de imposto de renda dos EUA de 40\%, seguindo relatório da KPMG - Auditores Independentes. 
Com essa atualização de parâmetros, o cálculo de custo médio ponderado de capital apresenta um valor de $9,98 \%$, ou seja, uma redução de 1,28 pontos percentuais em relação ao valor estipulado para o primeiro ciclo tarifário.

Contudo, quando da publicação do custo médio ponderado de capital para o segundo ciclo, a Associação Brasileira de Distribuidores de Energia Elétrica - $\mathrm{ABRADEE}^{70}$ recorreu à Aneel em nome das 64 distribuidoras atuantes no setor solicitando que fossem revistas algumas das variáveis utilizadas no cálculo. Além disso, apresentou representação solicitando a invalidação do cálculo realizado pela Aneel. As críticas apresentadas pela Associação estão reproduzidas na Nota Técnica nº 67/2007-SRE-ANEEL e estão resumidas abaixo:

a) crítica referente à amostra utilizada para cálculo da estrutura de capital do Chile e Grã-Bretanha e questionamento quanto às razões de se utilizar algumas e não a totalidade das empresas de distribuição;

b) crítica referente ao cálculo do beta americano, com três pontos de inconsistência no cálculo: (i) falta de transparência ao não divulgar as séries de dados utilizadas nos cálculos do beta americano; (ii) a técnica econométrica utilizada na estimação do mesmo não foi divulgada, sugerindo que esta poderia estar incorreta ao compará-la com estimativas de outra fonte de dados (Bloomberg); e (iii) que a amostra de empresas utilizadas no cálculo não se encontra coerente com o critério adotado na sua escolha. Quanto a esse ponto a ABRADEE apresenta os valores dos betas estimados (segundo a requerente) pela empresa Bloomberg para a amostra de empresas consideradas pela Aneel. Os valores dos betas apresentados bem como a estrutura de capital das empresas se mostraram diferentes dos apresentados pela Aneel. Além disso, realizou uma média simples dos betas alavancados e afirma ser este maior que o beta considerado pela Agência.

A Aneel apresentou na Nota Técnica 67/2007-SRE-ANEEL uma análise das críticas da ABRADEE e, além disso, resolveu rever não somente os pontos abordados mais todo o cálculo e disponibilizou em seu website todas as séries de dados utilizados.

\footnotetext{
${ }^{70}$ Segundo a Nota técnica n 67/2007-SRE/ANEEL, em janeiro de 2007, a ABRADEE - Associação Brasileira de Distribuidores de Energia, requereu a invalidação da Resolução ANEEL no 246/2006, a qual fixava o custo médio de capital para as distribuidoras de $9,98 \%$ para o segundo ciclo tarifário. Esta nota descreve os pontos em que a Associação entende que devam ser mudados.
} 
Ao proceder a ajustes em todas as variáveis, o custo de capital final apresentou uma redução de $9,98 \%$ para $9,95 \%$, ou seja, uma redução de 1,31 pontos percentuais em relação ao primeiro ciclo tarifário.

Outros autores também apresentam críticas aos parâmetros adotados pela Aneel. A seguir são apresentadas algumas delas referentes aos critérios de definição de variáveis e cálculo do WACC regulatório. As críticas não são quanto à metodologia, uma vez que esta encontra suporte na literatura conforme apresentado por Camacho (2004), que argumenta que é cada vez maior o consenso na utilização do Capital Asset Princing Model - CAPM em combinação com o Weighted Average Cost of Capital (WACC), modelo-padrão que vem sendo utilizado pela quase totalidade das agências reguladoras. Entre os países analisados, destacam-se Inglaterra, Austrália, Nova Zelândia, Estados Unidos, Espanha, Argentina e Chile.

Segundo Camacho, Rocha e Bragança (2006), questões aparentemente simples como as definições sobre taxa livre de risco, prêmio de risco, e periodicidade e intervalos de série, ou questões mais complexas como a estimação do WACC para países emergentes, definição do índice de mercado (global ou local), estimação do risco sistemático (beta), a adoção ou não do risco país e as particularidades inerentes do setor de eletricidade brasileiro, são ainda objeto de ampla discussão e pouco consenso.

Em relação ao WACC definido pela Aneel, Camacho, Rocha e Bragança (2006) recomendam que alguns ajustes poderiam ser feitos na estimação das variáveis utilizadas no cálculo do CAPM: ajuste para o risco país e ajuste do risco cambial.

O ajuste referente ao risco país seria a adoção da totalidade do risco país representado pela totalidade do índice Emerging Markets Bonds Index Plus relativo ao Brasil (EMBI+Brazil) ao contrário do índice parcial adotado pela Aneel.

Adicionalmente, essa abordagem tem como mérito se configurar como opção simples e replicável, qualidades desejáveis a qualquer regulação. Entretanto, por ser um parâmetro volátil e ter apresentado acentuada queda nos últimos três anos, os autores consideram diversos cenários para a variável risco país.

Quanto ao risco cambial recomendam contrariamente à regulação vigente, a adoção da totalidade do risco país, que além de ser forma consagrada na teoria de finanças em se tratando de economias em desenvolvimento, aliado à legislação vigente referente aos reajustes tarifários e ao pleno desenvolvimento dos derivativos financeiros no mercado brasileiro, torna desnecessário o acréscimo de um prêmio de risco cambial ao custo de capital estimado pelo regulador. 
Em Sanvicente e Minardi (2004), encontra-se a afirmação de que é possível estimar custos de capital com dados correntes de mercado, utilizando-se predominantemente os dados do próprio mercado de capitais do Brasil em lugar de recorrer a dados de mercados mais desenvolvidos como o mercado americano. Além disso, o trabalho indica como é possível descobrir com dados correntes qual é a estrutura ótima de capital de uma empresa para aplicação como "estrutura padrão" nos processos de estimação de custo médio de capital. Essa abordagem é difere da abordagem utilizada pela Aneel. O autor apresenta críticas especificamente às variáveis do modelo: calculo do custo de capital próprio, de terceiros e estrutura de capital.

No artigo, os autores apresentam o cálculo do custo de capital próprio para uma empresa de distribuição de energia elétrica baseando-se somente em dados do próprio mercado de capitais brasileiro. Para a realização dos cálculos foram coletados os dados de demonstrações financeiras de todas as empresas brasileiras disponíveis no banco de dados da Economática. Detalhes do cálculo podem ser vistos em Sanvicente e Minardi (1999 e 2004).

Esses autores concluem que nos processos de revisão tarifária de empresas sob regulação econômica no Brasil é possível calcular o custo médio de capital com base em dados do mercado brasileiro e argumentam que o enfoque proposto pode contribuir para permitir, na determinação da taxa de retorno, a visualização das condições que um investidor consideraria ao tomar suas decisões e não médias históricas de retornos como vêm fazendo as agências reguladoras. Ressaltam ainda que as agências vêm desprezando as informações disponíveis nos preços correntes de mercado de títulos.

O estabelecimento de uma taxa de remuneração de capital pela agência reguladora nas revisões tarifárias com o cálculo de um WACC regulatório envolvendo variáveis como risco país, risco do negócio e risco regulatório demonstra o entendimento do regulador quanto às variáveis que devem compor um custo de oportunidade de capital e também é importante sinalizador para a definição de tarifas compatíveis com o que o mercado espera e com o que o consumidor pode arcar, trazendo efetivamente para o ambiente regulado a simulação de um mercado competitivo.

Ao estabelecer metas de estrutura de capital "não" baseadas na estrutura de capital da distribuidora no cálculo do WACC regulatório e penalizar a gestão financeira ineficiente por outro lado com intervenção e multas, o regulador demonstra que o equilíbrio econômicofinanceiro do contrato será alcançado, aí incluída a remuneração do capital prevista, caso sejam atingidos os parâmetros de estrutura de capital observados na definição do WACC na revisão tarifária. 
Ressalta-se nesse sentido que no início dos contratos, na privatização, o ente privado não tinha nenhuma garantia de qual seria a taxa a ser recebida nas tarifas. A garantia expressa pelo contrato referia-se a "remuneração" do capital investido e cobertura dos custos operacionais e o acordo de que as regras de reajuste na revisão tarifária resolveriam a equação do equilíbrio econômico-financeiro.

\subsection{Quota de Reintegração Regulatória}

Enquanto a remuneração do investimento é realizada por meio da apuração do custo de capital, a quota de reintegração regulatória se destina a recompor esse mesmo capital por meio de amortizações periódicas.

A Resolução Aneel nº 234/2006, que trata do aperfeiçoamento das metodologias de cálculo da revisão tarifária periódica do segundo ciclo, apresenta a seguinte definição: "Quota de Reintegração Regulatória: quota que considera a depreciação e a amortização dos investimentos realizados, visando recompor os ativos afetos à prestação do serviço, ao longo da sua vida útil”.

A recomposição do bem ou sua atualização é necessária devido à redução no potencial de uso em serviço em consequência do desgaste, antiguidade ou obsolescência. A representação da depreciação como redução do valor dos ativos na medida em que estes são utilizados é o procedimento contábil aplicado para evidenciar a redução do potencial de gerar receitas. Assim, o uso progressivo de um ativo é compensado pela receita que seu prestador recebe a cada período tarifário, o que permite dispor de recursos para sempre repor os ativos no final de sua vida útil.

Para o efetivo cálculo da Quota de Reintegração Regulatória - QRR é adotado um percentual da vida útil a partir da taxa média de depreciação de cada distribuidora fornecida pela própria empresa e fiscalizada pela Aneel. A taxa de depreciação referenciada é o instrumento utilizado para definir o período em que os ativos estarão gerando receitas e benefícios para a empresa regulada.

Tendo em vista que as taxas de depreciação atualmente em vigor, segundo o Manual de Contabilidade do Serviço Público de Energia Elétrica - MCSPEE refletem a vida útil dos bens, tais taxas devem ser utilizadas para fins de revisão tarifária periódica a partir das datas de entrada em operação dos ativos.

As taxas de depreciação utilizadas tanto para registro no imobilizado e as utilizadas no processo de revisão tarifária são as da Resolução $n^{\circ}$ 240, de 05/12/2006, que estipula taxas 
anuais para cada tipo de unidade de cadastro. Essas taxas são, assim, individualizadas por equipamento, por sistemas de suporte, por sistema funcional, etc.

Visando definir a depreciação contábil, Iudícibus, Martins e Gelbcke (2007, p. 212) apresentam que: "para a contabilidade, a depreciação é um custo amortizado". Ao discutir sobre a natureza da depreciação, apresentam que "os lançamentos periódicos de depreciação não passam na realidade de um procedimento contábil pelo qual se considera despesa de um período uma parte do custo de um elemento do ativo comprado anteriormente" (IUDÍCIBUS, MARTINS E GELBCKE, 2007, p. 218).

Esses autores registram que este é um lançamento que não afeta as disponibilidades da empresa agora. Trata-se da recuperação de um desembolso passado e que isso nada tem a ver com o desembolso necessário à reposição do ativo.

Quando evidenciada pela Demonstração do Resultado do Exercício - DRE, trata-se de uma despesa não desembolsável, pois não representa na realidade um comprometimento de caixa da empresa.

Isso fica mais claro ao observar um exemplo de um ativo com valor de aquisição de $\mathrm{R} \$ 100.000,00$ e com taxa de depreciação de $10 \%$ ao ano, ou seja, esse bem seria totalmente depreciado em 10 anos.

Quadro 7 - Demonstrativos financeiros - modelo societário atual

\begin{tabular}{|l|c|c|c|c|c|c|c|}
\hline \multicolumn{1}{|c|}{ Balanço } & Início & Ano 1 & Ano 2* & Ano 7 & Ano 8 & Ano 9 & Ano 10 \\
\hline ATIVO & & & & & & & \\
\hline Caixa & & 9.260 & 18.520 & 261.757 & 455.954 & 650.150 & 880.362 \\
\hline Ativo Imobilizado & 100.000 & 100.000 & 100.000 & 100.000 & 100.000 & 100.000 & 100.000 \\
\hline Depreciação acumulada & - & - & $(\mathbf{1 0 . 0 0 0})$ & $(\mathbf{6 0 . 0 0 0})$ & $(\mathbf{7 0 . 0 0 0 )}$ & $(\mathbf{8 0 . 0 0 0 )}$ & $(\mathbf{9 0 . 0 0 0})$ \\
\hline Depreciação do ano & & $\mathbf{( 1 0 . 0 0 0 )}$ & $\mathbf{( 1 0 . 0 0 0 )}$ & $\mathbf{( 1 0 . 0 0 0 )}$ & $(\mathbf{1 0 . 0 0 0 )}$ & $\mathbf{( 1 0 . 0 0 0 )}$ & $(\mathbf{1 0 . 0 0 0 )}$ \\
\hline Saldo líquido do AIS & 100.000 & 90.000 & 80.000 & 30.000 & 20.000 & 10.000 & - \\
\hline TOTAL DO ATIVO & $\mathbf{1 0 0 . 0 0 0}$ & $\mathbf{9 9 . 2 6 0}$ & $\mathbf{9 8 . 5 2 0}$ & $\mathbf{2 9 1 . 7 5 7}$ & $\mathbf{4 7 5 . 9 5 4}$ & $\mathbf{6 6 0 . 1 5 0}$ & $\mathbf{8 8 0 . 3 6 2}$ \\
\hline DRE & & & & & & & \\
\hline Receita tarifária & - & 11.260 & 11.260 & 11.260 & 11.260 & 11.260 & 11.260 \\
\hline Despesa depreciação & - & $(10.000)$ & $(10.000)$ & $(10.000)$ & $(10.000)$ & $(10.000)$ & $(10.000)$ \\
\hline Resultado do Exercício & - & $\mathbf{1 . 2 6 0}$ & $\mathbf{1 . 2 6 0}$ & $\mathbf{1 . 2 6 0}$ & $\mathbf{1 . 2 6 0}$ & $\mathbf{1 . 2 6 0}$ & $\mathbf{1 . 2 6 0}$ \\
\hline FLUXO DE CAIXA & & & & & & & \\
\hline Caixa inicial & & - & 11.260 & 67.560 & 78.820 & 90.080 & 101.340 \\
\hline Recebimento de tarifas & & 11.260 & 11.260 & 11.260 & 11.260 & 11.260 & 11.260 \\
\hline Despesa operacional & & - & - & - & - & - & - \\
\hline Caixa final & & $\mathbf{1 1 . 2 6 0}$ & $\mathbf{2 2 . 5 2 0}$ & $\mathbf{7 8 . 8 2 0}$ & $\mathbf{9 0 . 0 8 0}$ & $\mathbf{1 0 1 . 3 4 0}$ & $\mathbf{1 1 2 . 6 0 0}$ \\
\hline
\end{tabular}

Nota: *Foi compactado do ano 3 ao ano 6 e foi ocultado o passivo para efeito de simplificação; AIS: Ativo Imobilizado em Serviço. 
O que se observa é que o efeito da depreciação nos demonstrativos é a redução do imobilizado e sua correspondente despesa é apresentada na DRE. No entanto, sem efeito no fluxo de caixa da empresa. No ano 10, esse bem estaria totalmente depreciado sem valor contábil.

Nos processos de revisão tarifária periódica das distribuidoras é apresentada uma taxa média de depreciação - TMD utilizada para cálculo da quota de reintegração regulatória. Não foram encontradas nas notas técnicas emitidas pela Aneel referências detalhadas ou estudos quanto à formação dessa taxa.

Dessa forma, de acordo com a definição de QRR apresentada pela Aneel, concluí-se que esta utiliza a TMD como parâmetro de cálculo da QRR na crença de que esse percentual aplicado sobre a Base de Remuneração Regulatória é suficiente para cumprir as suas finalidades de recompor bens e amortizar capital. Assim, de alguma forma, a QRR deveria estar evidenciada nas demonstrações financeiras das distribuidoras de energia elétrica. O tema é analisado no Capitulo 4, item 4.2.1.2.

\subsection{CONSIDERAÇÕES DE FINAL DE CAPÍTULO}

Este capítulo apresentou como a contabilidade regulatória contribui nas atribuições da regulação econômica e nas funções regulatórias, com destaque para a fiscalização da situação financeira do negócio, bem como sua participação na regulação tarifária, evidenciando os instrumentos contábeis envolvidos nesses processos.

Merece atenção especial, no aspecto da fiscalização, os exemplos de casos onde a Aneel interferiu na concessão diante de informações obtidas principalmente nas demonstrações financeiras que indicavam o desequilíbrio do contrato e que apontavam para a perda de qualidade do serviço para a população.

Relevante é a contribuição da contabilidade na formação do preço (tarifa) exigida como contrapartida pela prestação do serviço e que resulta em uma receita de equilíbrio que garanta a realização das premissas previstas no contrato de concessão, em especial seu equilíbrio econômico-financeiro, com cobertura dos custos da prestação do serviço, realização de investimentos de melhoria e remuneração do capital investido.

Conclui-se acerca do papel da contabilidade regulatória para a regulação econômica, quer seja para exercer função de controle associada à fiscalização econômico-financeira ou como balizador para a BRR na fixação de retorno dos investimentos realizados a serem 
recuperados via receita de equilíbrio, que apresenta contribuição efetiva na evidenciação e definição do equilíbrio da concessão.

Também visualizam-se os ajustes feitos pela contabilidade regulatória nas demonstrações financeiras no processo tarifário para fixar a receita a ser recebida dos usuários que garanta o equilíbrio econômico-financeiro do contrato, destacando-se a criação do ativo imobilizado em serviço regulatório, da base de incidência (BRR) para a taxa de remuneração de capital, e da quota de reintegração regulatória para recomposição do capital investido no negócio.

Não foi encontrada nenhuma restrição à adoção das novas normas internacionais de contabilidade aos processos analisados. Ao contrário, nota-se que há propensão no sentido da melhor evidenciação do desempenho econômico-financeiro da atividade concedida, considerando seu objetivo principal em demonstrar a essência econômica das transações.

Visando identificar os benefícios advindos da adoção das interpretações internacionais para a contabilidade regulatória, no próximo capítulo simula-se um contrato de concessão de distribuição evidenciado pela contabilidade em seu modelo societário atual e na forma da interpretação IFRIC 12. 


\section{ANÁliSE COMPARATIVA: MODELO SOCIETÁRIO ATUAL VERSUS MODELO DE ACORDO COM A IFRIC 12}

De acordo com a abordagem da contabilidade regulatória apresentada neste trabalho, esta tem por finalidade o controle e o monitoramento da atividade concedida com vistas a resguardar a fixação e a manutenção do equilíbrio econômico-financeiro pactuado no contrato de concessão, procedendo a ajustes específicos na contabilidade societária para o atendimento das funções regulatórias.

Buscou-se no capítulo anterior demonstrar os instrumentos contábeis utilizados na regulação econômica e a utilização da informação contábil para fixar e monitorar o EEF, estabelecendo, dessa forma, condições para identificação do equilíbrio econômico-financeiro presente nos contratos de concessão, nas demonstrações contábeis.

Para isso, é realizada uma simulação da evidenciação dos fatos econômicos decorrentes de um contrato de concessão pelos demonstrativos financeiros de acordo com o modelo societário atual e a simulação da migração desse mesmo contrato e mesmos eventos para os demonstrativos financeiros elaborados de acordo com alguns dos padrões internacionais de contabilidade, a interpretação IFRIC 12.

O modelo societário atual é feito com base no modelo estabelecido pela Lei 6.404/76, antes da Lei 11.638/2007, e nos normativos expedidos pela Aneel, enquanto que o modelo de acordo com os padrões internacionais de contabilidade segue a interpretação IFRIC 12 Service Concession Arrangements.

A análise realizada neste Capítulo está baseada nos fatos econômicos mais relevantes que ocorrem durante a vigência de um contrato de concessão, que se referem:

1. ao investimento inicial, ou seja, a aquisição do direito de exploração da prestação do serviço de distribuição de energia elétrica em determinada região do país. Nesta simulação admite-se a modalidade de concessão de prestação de serviço não precedida de licitação, semelhante à renovação de uma concessão existente;

2. à realização de investimentos na aquisição ou modernização dos ativos, com o objetivo de atender à expansão da demanda ou de melhoria na performance econômica da entidade;

3. à realização das revisões tarifárias periódicas, que fixam a receita de equilíbrio, fator preponderante para ajuste do contrato às condições econômicas inicialmente acordadas. 
Nesse contexto, é importante retomar a informação de que o equilíbrio econômicofinanceiro (EEF) da concessão é estipulado inicialmente na assinatura do contrato, onde as partes concordam que condições nele previstas, no ato da assinatura do contrato, conferem condições adequadas para a remuneração do capital (CAPEX) e para fazer face aos custos operacionais (OPEX).

Note-se que o EEF previsto no contrato de concessão equivale a dizer que a receita tarifária estimada no início do contrato é suficiente para cobrir os gastos operacionais e garantir a remuneração e o retorno do capital investido.

No início do contrato, não há cálculo de tarifa a ser cobrada pela prestação do serviço público, pois na assinatura do contrato as partes pactuam que as tarifas vigentes conferem situação de equilíbrio econômico-financeiro.

Diante disso, a revisão tarifária assume papel fundamental na manutenção do EEF, visto que é por meio dela que será ajustada a receita a ser obtida com a prestação do serviço que continue a garantir a condição prevista inicialmente.

Assim, este Capítulo compreende a simulação de demonstrações financeiras considerando os fatos econômicos acima indicados de acordo com o modelo societário atual e no modelo IFRIC 12, discutindo o papel da contabilidade regulatória na formação dos itens que compõem a receita de equilíbrio e buscando a identificação do equilíbrio econômicofinanceiro dos contratos de concessão nas demonstrações contábeis de acordo com os dois modelos.

A análise apresenta as seguintes etapas:

a) o início do contrato de concessão, com a realização do investimento inicial e primeiros períodos de operação do serviço público, conforme as premissas apresentadas no item 1 acima;

b) realização da primeira revisão tarifária periódica, 05 anos após a formalização do contrato, considerando o modelo atual de contabilização e analisando-se os itens e a rotina de cálculo que compõem a receita tarifária de equilíbrio;

c) realização da segunda revisão tarifária periódica, 10 anos após a formalização do contrato, com a realização de novos investimentos e incluindo-se na análise a divulgação de demonstrações financeiras com a adoção das normas internacionais de contabilidade.

Nas simulações considera-se que o contrato foi assinado em 1998, tendo como intervalo revisional o período de 5 anos. A primeira revisão tarifária ocorre, portanto, em 
2003, dentro do primeiro ciclo tarifário ocorrido (2002-2006), e a segunda em 2008, dentro do segundo ciclo tarifário (2007-2011). Para efeito de análise, o resultado da revisão de 2008 é replicado até o final do contrato, considerando que seus efeitos já foram representados nas duas revisões simuladas. Além disso, serão observados os seguintes parâmetros gerais:

a) prazo do contrato de 20 anos, abrangendo o período de 1998 a 2018;

b) valor do ativo adquirido com capital próprio: $\mathrm{R} \$ 1.000 .000,00$;

c) investimento realizado no ano de 2004, decorrente de substituição de bens obsoletos, no valor de $\mathrm{R} \$ 100.000,00$, e baixa correspondente do custo depreciado no valor de $\mathrm{R} \$ 30.000,00$;

d) investimento realizado no ano de 2009 em novas instalações no valor de R\$ 150.000,00, decorrente de expansão da demanda;

e) despesas com operação de $2 \%$ dos investimentos;

f) taxa de depreciação para os bens do ativo imobilizado de $3,5 \%{ }^{71}$;

g) a receita tarifária inicial é estimada de forma a conferir o equilíbrio econômicofinanceiro ao contrato, vide item 3.3.4;

h) WACC regulatório de $11,26 \%^{72}$ para a primeira revisão tarifária e de $9,95 \%{ }^{73}$ para a segunda, fixados pelo regulador;

i) os efeitos tributários são considerados somente no WACC;

j) os exemplos não buscam demonstrar o que ocorre ao final do contrato, pois isto não configura objeto deste trabalho.

Sobre a realização das revisões tarifárias, cabe destacar que de acordo com o contrato de concessão, especificamente a cláusula sétima ${ }^{74}$, a Aneel procederá às revisões dos valores das tarifas, alterando-as para mais ou para menos, considerando a estrutura de custos e de mercado da distribuidora, os níveis de tarifas observados em empresas similares no contexto internacional e os estímulos à eficiência e à modicidade tarifária de acordo com o cronograma

\footnotetext{
${ }^{71}$ Esse percentual é um arredondamento para baixo da média encontrada no Quadro 10 - Taxa média de depreciação, a seguir.

72 Nota Técnica n⿳ำ 164/2006-SRE/ANEEL.

${ }^{73}$ Resolução Aneel 259/2007.

74 "Sétima Subcláusula - A ANEEL, de acordo com o cronograma apresentado nesta subcláusula, procederá às revisões dos valores das tarifas de comercialização de energia, alterando-os para mais ou para menos, considerando as alterações na estrutura de custos e de mercado da DISTRIBUIDORA, os níveis de tarifas observados em empresas similares no contexto nacional e internacional, os estímulos à eficiência e à modicidade das tarifas. Estas revisões obedecerão ao seguinte cronograma: a primeira revisão será procedida um ano após o quarto reajuste anual concedido, conforme previsto na Terceira Subcláusula; a partir desta primeira revisão, as subseqüentes serão realizadas a cada 4 (quatro) anos"(Contrato de Concessão 009/2002 - ANEEL - Companhia Piratininga de Força e Luz - CPFL).
} 
estabelecido contratualmente. Sendo assim, as revisões tarifárias são motivadas por força contratual e para que sejam revistos, principalmente, a estrutura de custos e de mercado e os estímulos à eficiência e à modicidade tarifária.

\subsection{O INÍCIO DO CONTRATO DE CONCESSÃO}

Considerando o modelo societário vigente e a forma de contabilização das concessões, a demonstração da transação ocorrida na assinatura do contrato de concessão está calcada em premissas relacionadas aos ativos físicos usados na prestação do serviço de energia elétrica, conforme demonstrado nos capítulos dois e três.

O modelo contábil utilizado para a evidenciação dos fatos econômicos resultantes do contrato de concessão tem como origem os preceitos expressos na Lei das Sociedades por Ações antes de 2007 e nas resoluções emanadas da Aneel, sem esquecer ainda da legislação fiscal.

Ressalta-se que tais normativos têm como característica comum a previsão do registro dos bens utilizados na prestação do serviço de energia elétrica como sendo patrimônio da distribuidora, constante do ativo permanente imobilizado da distribuidora. Além disso, vale lembrar que as taxas de depreciação utilizadas são regulatórias definidas pela Resolução Aneel no 240/2006.

$\mathrm{Na}$ interpretação da Lei de Concessões e do previsto no contrato de concessão, considera-se que tais ativos foram transferidos para o ente privado mediante o pagamento ao estado de um valor que lhe garanta o direito de explorar o serviço público durante um determinado período de tempo. Findo esse prazo, os ativos não completamente depreciados serão revertidos ao estado.

Conforme mencionado anteriormente, no momento da assinatura do contrato, distribuidora e poder concedente pactuam que as tarifas vigentes conferem equilíbrio. Sendo assim, foi estimada a receita tarifária para o período inicial, considerando uma taxa de retorno de $11,26 \%^{75}$ aplicada sobre o valor do ativo imobilizado de $\mathrm{R} \$ 1.000 .000,00$, resultando em

\footnotetext{
${ }^{75}$ É importante notar que mesmo com $100 \%$ de capital próprio foi considerado como taxa de remuneração o WACC, que representa a ponderação média dos custos de capital próprio e de capital de terceiros. Conforme apresenta (Martins, 2006). A distorção que essa consideração incorre é que na ausência de capital de terceiros, há igualdade entre o retorno mínimo esperado do ativo e o custo de capital próprio. Se houvesse a introdução de capital de terceiros, o custo de capital próprio se elevaria, ficando superior ao risco básico do ativo. Esse diferencial do custo de capital explica a diminuição de aproveitamento do valor do ativo por parte dos acionistas. Ver detalhes sobre essa discussão em Martins (2006).
} 
um valor de $\mathrm{R} \$ 112.600,00$. Esse valor é suficiente para fazer frente aos custos operacionais incorridos durante o período (1998-2002), até a primeira revisão tarifária ocorrer ${ }^{76}$.

Sendo assim, para realização das simulações, as demonstrações financeiras da entidade poderiam ser representadas no inicio do contrato e pelo período que antecede a primeira revisão tarifária da seguinte forma: considerando os parâmetros fixados na abertura deste Capítulo e seguindo o modelo de apresentação de acordo com o modelo societário atual, apresentado no quadro abaixo.

Quadro 8 - Demonstrativos financeiros - modelo societário atual

\begin{tabular}{|l|c|c|c|c|c|}
\hline & \multicolumn{5}{|c|}{ Período Inicial } \\
\hline BALANÇO CONCESSÃO & $\mathbf{1 9 9 8}$ & $\mathbf{1 9 9 9}$ & $\mathbf{2 0 0 0}$ & $\mathbf{2 0 0 1}$ & $\mathbf{2 0 0 2}$ \\
\hline ATIVO & & & & & \\
\hline Caixa & & 92.600 & 185.200 & 277.800 & 370.400 \\
\hline Ativo Imobilizado & 1.000 .000 & 1.000 .000 & 1.000 .000 & 1.000 .000 & 1.000 .000 \\
\hline Depreciação acumulada & - & - & $(35.000)$ & $(70.000)$ & $(105.000)$ \\
\hline Depreciação do ano & & $\mathbf{( 3 5 . 0 0 0 )}$ & $\mathbf{( 3 5 . 0 0 0 )}$ & $\mathbf{( 3 5 . 0 0 0 )}$ & $\mathbf{3 5 . 0 0 0 )}$ \\
\hline Saldo líquido do AIS & 1.000 .000 & 965.000 & 930.000 & 895.000 & 860.000 \\
\hline TOTAL DO ATIVO & $\mathbf{1 . 0 0 0 . 0 0 0}$ & $\mathbf{1 . 0 5 7 . 6 0 0}$ & $\mathbf{1 . 1 1 5 . 2 0 0}$ & $\mathbf{1 . 1 7 2 . 8 0 0}$ & $\mathbf{1 . 2 3 0 . 4 0 0}$ \\
\hline Passivo & & & & & \\
\hline Patrimônio Líquido & 1.000 .000 & 1.057 .600 & 1.115 .200 & 1.172 .800 & 1.230 .400 \\
\hline Cap. Social & 1.000 .000 & 1.000 .000 & 1.000 .000 & 1.000 .000 & 1.000 .000 \\
\hline Resultado do exercício & - & 57.600 & 57.600 & 57.600 & 57.600 \\
\hline Lucros/Prejuízos acumulados & & - & 57.600 & 115.200 & 172.800 \\
\hline TOTAL DO PASSIVO & $\mathbf{1 . 0 0 0 . 0 0 0}$ & $\mathbf{1 . 0 5 7 . 6 0 0}$ & $\mathbf{1 . 1 1 5 . 2 0 0}$ & $\mathbf{1 . 1 7 2 . 8 0 0}$ & $\mathbf{1 . 2 3 0 . 4 0 0}$ \\
\hline DRE & & & & & \\
\hline Receita tarifária & - & 112.600 & 112.600 & 112.600 & 112.600 \\
\hline Despesa operacional & - & $(20.000)$ & $(20.000)$ & $(20.000)$ & $(20.000)$ \\
\hline Despesa não operacional (baixa) & & & & & \\
\hline Despesa amortização/depreciação & - & $(35.000)$ & $(35.000)$ & $(35.000)$ & $(35.000)$ \\
\hline RESULTADO DO EXERCÍCIO & - & $\mathbf{5 7 . 6 0 0}$ & $\mathbf{5 7 . 6 0 0}$ & $\mathbf{5 7 . 6 0 0}$ & $\mathbf{5 7 . 6 0 0}$ \\
\hline FLUXO DE CAIXA & & & & & \\
\hline Caixa inicial & & - & 92.600 & 185.200 & 277.800 \\
\hline Recebimento de tarifas & & 112.600 & 112.600 & 112.600 & 112.600 \\
\hline Realização de Investimento & & & & & \\
\hline Despesa operacional & & 92.600 & 185.200 & 277.800 & 370.400 \\
\hline Caixa final & & & & & \\
\hline
\end{tabular}

Nota: - Itens analisados: ativo imobilizado em serviço líquido e despesa de depreciação.

De acordo com o MCSPEE (2001, p. 27), o grupo imobilizado deverá ser registrado ao custo de aquisição ou construção, deduzido de depreciação calculada pelo método linear. De acordo com a Instrução Contábil n⿳ำ 6.1.5 - Cadastro e Controle de Bens e Direitos, do

\footnotetext{
${ }^{76}$ Conforme explicitado no Capítulo 3, anualmente as tarifas são reajustadas via IGPM. Os reajustes corrigem a receita tarifária, mas não os elementos centrais do processo de equilíbrio econômico-financeiro, ou seja, a parcela B (formada pelos custos operacionais e custos de capital).
} 
MCSPEE (2001), os bens e direitos em função do serviço concedido serão cadastrados e controlados pela distribuidora e permissionária em sistemas auxiliares ou em registros suplementares, por meio de Unidade de Cadastro - UC e Unidade de Adição e Retirada UAR e por Ordem de Imobilização - ODI

Note-se, entretanto, que o método adotado está de acordo com o que preceitua o modelo societário $^{77}$, com observância das orientações da Aneel ${ }^{78}$. Sendo assim, todos os direitos relacionados à concessão estão contabilizados no ativo imobilizado.

Observa-se, ainda, a aplicação da contabilidade societária na sua forma tradicional, evidenciando os valores relacionados a todo o conjunto do ativo permanente da entidade objeto de análise. Assim, no período inicial houve apenas o registro do ativo permanente e a evolução de seu saldo líquido decorrente dos efeitos da depreciação linear, conforme os critérios de depreciação definidos pela Aneel.

Cabe, contudo, destacar que a interpretação IFRIC 12 prevê tratamento para o ativo diferente do acima estabelecido, cujo detalhamento está contido no item 4.3.1, com o registro nas demonstrações da distribuidora apenas do direito de exploração do negócio como sendo um ativo intangível avaliado por fair value, haja vista que os bens utilizados na prestação do serviço público continuariam sendo propriedade do estado.

\subsection{AS REVISÕES TARIFÁRIAS PERIÓDICAS}

A revisão tarifária periódica trata-se de momento complexo da existência do contrato de concessão, onde a contabilidade regulatória exerce papel fundamental, contribuindo com dados e informações em diversas etapas do processo de revisão.

De acordo com o apresentado no item 3.3.2 deste trabalho, que trata das variáveis contábeis, a definição dos OPEX e CAPEX alimenta o processo regulatório impactando nas tarifas e, consequentemente, no fluxo de caixa da empresa e assim no seu valor de mercado.

Dessa forma, o momento da definição dessas variáveis é a revisão tarifária, tornando-se assim crucial para os agentes envolvidos, principalmente distribuidoras e consumidores.

\footnotetext{
${ }^{77}$ De acordo com a Lei 6.404/76, art. 179: As contas serão classificadas do seguinte modo:... IV - no ativo imobilizado: os direitos que tenham por objeto bens corpóreos destinados à manutenção das atividades da companhia ou da empresa ou exercidos com essa finalidade, inclusive os decorrentes de operações que transfiram à companhia os benefícios, riscos e controle desses bens.

${ }^{78}$ De acordo com MCSPEE (2001, p. 27), item 6.1.5 - Cadastro e Controle de Bens e Direitos, os bens e direitos em função do serviço concedido serão cadastrados e controlados pela distribuidora e permissionária em sistemas auxiliares ou em registros suplementares, por meio de Unidade de Cadastro - UC e Unidade de Adição e Retirada - UAR e por Ordem de Imobilização - ODI.
} 
A receita tarifária que vigorará para o ciclo tarifário seguinte, também chamada de receita de equilíbrio, é a receita que garantirá a manutenção do equilíbrio econômicofinanceiro previsto no contrato de concessão.

Vale ressaltar que, previamente ao início dos ciclos de revisão tarifária, a Aneel coloca em audiência pública as metodologias de cálculo para fixação da receita de equilíbrio, com o objetivo de colher contribuições dos diversos agentes envolvidos (distribuidoras, consumidores, associações, etc).

Isso ocorreu em 2002, para o primeiro ciclo (Audiência Pública 005/2002 e 023/2002) e em 2006/2007 para o segundo ciclo tarifário (Audiência Pública 008/2006 e 052/007).

Além disso, com antecedência em torno de 2 meses da data da revisão de cada distribuidora, são colocados em audiência pública os parâmetros utilizados no cálculo e os valores a serem fixados como receita de equilíbrio para a distribuidora, demonstrando a busca do regulador por transparência no processo.

\subsubsection{Análise dos componentes da Receita de Equilíbrio}

Conforme tratado no Capítulo 3, a receita de equilíbrio fixada nos processos de revisão tarifária é formada pela Parcela A (compra e transporte de energia, encargos setoriais e tributos) e pela Parcela B (custos operacionais e remuneração total de capital).

Os componentes da Parcela A, chamada de "custos não gerenciáveis", são repassados integralmente para as tarifas ${ }^{79}$ sem o estabelecimento de metodologias de cálculo.

É na Parcela B, denominada de “custos gerenciáveis”, que são inseridos os incentivos para a distribuidora melhorar sua eficiência operacional, ou seja, é onde mais efetivamente acontece o modelo de regulação por incentivos adotado pela Aneel. Isso pode ser visto na formação dos custos operacionais (OPEX) considerados eficientes e na remuneração total de capital (CAPEX).

Primeiramente, será analisada a remuneração total de capital, cujas variáveis de cálculo são a Base de Remuneração Regulatória - BRR, o WACC regulatório e a Quota de Reintegração Regulatória - QRR. Em seguida são analisados os custos operacionais. A análise desses componentes antes das simulações visa o entendimento da formação dos valores a serem incluídos na receita de equilíbrio fixada nos processos de revisão tarifária periódica.

\footnotetext{
79 A exceção do item compra de energia, onde é feito uma analise sobre o montante apresentado pela distribuidora para atender a seu mercado.
} 


\subsubsection{Base de Remuneração Regulatória}

A BRR é formada pelo Ativo Imobilizado em Serviço - AIS, avaliado a custo de reposição de acordo com a metodologia do valor novo de reposição, conforme estabelecido pela Resolução Aneel 493/2002.

Um levantamento dos valores da BRR em comparação com os valores de ativo imobilizado em serviço líquido publicados nos demonstrativos financeiros de 15 distribuidoras apresenta os seguintes dados:

Quadro 9 - Proporção da BRR em relação ao ativo imobilizado líquido

\begin{tabular}{|c|c|c|c|c|c|c|c|c|}
\hline \multirow[b]{2}{*}{ EMPRESA } & \multicolumn{4}{|c|}{ 1a. Revisão Tarifária } & \multicolumn{4}{|c|}{ 2a. Revisão Tarifária } \\
\hline & $\begin{array}{c}\text { Ano da } \\
\text { Revisão }\end{array}$ & $\begin{array}{c}\text { BRR } \\
\text { líquida } \\
\text { (R\$ mil) } \\
\end{array}$ & $\begin{array}{c}\text { AIS } \\
(\mathbf{R} \$ \text { mil })\end{array}$ & $\begin{array}{c}\% \\
\text { BRR/AIS }\end{array}$ & $\begin{array}{l}\text { Ano da } \\
\text { Revisão }\end{array}$ & $\begin{array}{c}\text { BRR } \\
\text { líquida } \\
\text { (R\$ mil) } \\
\end{array}$ & $\begin{array}{c}\text { AIS } \\
\text { (R\$ mil) }\end{array}$ & $\begin{array}{c}\% \\
\text { BRR/AIS }\end{array}$ \\
\hline AES-SUL & 2003 & 670,8 & 619,8 & $108,2 \%$ & 2008 & 883,2 & 772,6 & $114,3 \%$ \\
\hline CEMIG & 2003 & $4.395,4$ & $3.262,3$ & $134,7 \%$ & 2008 & $4.664,5$ & $3.783,8$ & $123,3 \%$ \\
\hline COELBA & 2003 & $2.033,6$ & $1.521,2$ & $133,7 \%$ & 2008 & $2.773,8$ & $2.030,4$ & $136,6 \%$ \\
\hline COELCE & 2003 & 925,8 & 855,6 & $108,2 \%$ & 2007 & $1.350,3$ & $1.225,1$ & $110,2 \%$ \\
\hline COSERN & 2003 & 418,2 & 311,5 & $134,3 \%$ & 2008 & 593,1 & 381,7 & $155,4 \%$ \\
\hline CPFL & 2003 & $2.217,5$ & $1.304,1$ & $170,0 \%$ & 2008 & $2.325,5$ & $1.472,2$ & $158,0 \%$ \\
\hline ENERGIPE & 2003 & 233,0 & 186,6 & $124,9 \%$ & 2008 & 324,8 & 197,6 & $164,4 \%$ \\
\hline ENERSUL & 2003 & 655,6 & 619,8 & $105,8 \%$ & 2008 & 829,5 & 757,2 & $109,5 \%$ \\
\hline RGE & 2003 & 831,7 & 702,1 & $118,5 \%$ & 2008 & $1.192,1$ & 999,9 & $119,2 \%$ \\
\hline ELETROPAULO & 2003 & $7.326,3$ & $5.187,7$ & $141,2 \%$ & 2007 & $5.098,6$ & $5.078,5$ & $100,4 \%$ \\
\hline ELEKTRO & 2003 & $1.601,0$ & $1.047,5$ & $152,8 \%$ & 2007 & $1.727,7$ & $1.293,8$ & $133,5 \%$ \\
\hline BANDEIRANTE & 2003 & $1.091,9$ & 718,4 & $152,0 \%$ & 2007 & $1.221,3$ & 836,8 & $145,9 \%$ \\
\hline PIRATININGA & 2003 & 787,5 & 611,1 & $128,9 \%$ & 2007 & $1.025,0$ & 684,9 & $149,7 \%$ \\
\hline CFLCL(Energisa) & 2004 & 233,0 & 191,0 & $122,0 \%$ & 2008 & 194,7 & 167,5 & $116,3 \%$ \\
\hline ESCELSA & 2004 & 928,4 & 750,6 & $123,7 \%$ & 2007 & 952,5 & 796,7 & $119,6 \%$ \\
\hline Média & & & & $130,6 \%$ & & & & $130,4 \%$ \\
\hline Desvio padrão & & & & 0,18 & & & & 0,20 \\
\hline
\end{tabular}

Das 26 empresas distribuidoras de energia elétrica listadas na Comissão de Valores Mobiliários - CVM, 15 foram utilizadas para cálculo da proporção BRR em relação ao ativo imobilizado. A exclusão das demais 11 distribuidoras é motivada pelo fato de não ser possível isolar dos ativos publicados nas demonstrações financeiras aqueles relativos à atividade de distribuição.

\footnotetext{
${ }^{80}$ As notas técnicas podem ser encontradas no endereço eletrônico da Aneel (www.aneel.gov), no item audiência pública, acesso ao ano de revisão e acesso a revisão tarifária da distribuidora.
} 
A data base do valor do ativo imobilizado considerada foi Dezembro do ano anterior ao ano da revisão e o valor da BRR é o publicado no ano da revisão.

Pelo quadro verifica-se que toda a amostra analisada apresenta a mesma característica, ou seja, uma BRR superior ao ativo imobilizado líquido em serviço. O percentual médio apurado é de 130,6\% no primeiro ciclo e de 130,4\% apurado no segundo ciclo. Ou seja, em média, o custo de reposição é $30 \%$ maior do que o custo histórico (depreciado).

A contabilidade é o principal instrumento usado pelo regulador na fiscalização e validação da avaliação dos ativos, cujas atividades são realizadas com base nos registros contábeis, nos inventários e no fluxo de informação contábil enviado rotineiramente à Aneel.

Dessa forma, percebe-se a importância de uma contabilidade gerencial confiável, pois dela depende a validação da BRR da distribuidora, com reflexo em toda a remuneração de capital.

Visualiza-se ainda mais a importância da contabilidade, ao considerar que, na prática, o processo de avaliação de ativos para a revisão tarifária envolve os seguintes procedimentos: i) o regulador credencia um grupo de empresas avaliadoras aptas a realizar a avaliação; ii) a distribuidora tem a discricionariedade de contratar dentre as credenciadas; iii) a empresa avaliadora realiza a inspeção e avaliação dos ativos, seguindo os critérios da Aneel e utilizando o método do custo de reposição, e apresenta um Laudo de Avaliação dos ativos imobilizados em serviço para a distribuidora (nessa etapa distribuidora e avaliadora estão em permanente contato); e iv) a distribuidora submete este Laudo a Aneel, especificamente à Superintendência de Fiscalização Econômico-Financeira - SFF, a qual realiza uma visita de fiscalização do laudo na empresa distribuidora.

Para emitir seu parecer de aprovação ou não e solicitação de ajustes ao Laudo apresentado pela distribuidora, a equipe de fiscalização econômico-financeira conta com a contabilidade regulatória como sustentação aos argumentos apresentados pelo regulador no processo de validação da BRR, proporcionando ainda a redução de assimetria informacional e mitigando os efeitos de possíveis estratégias das distribuidoras na validação de laudos superavaliados a fim de aumentar a remuneração de capital.

\subsubsection{Quota de Reintegração Regulatória}

A Quota de Reintegração Regulatória - QRR é formada por um percentual médio de depreciação extraído dos registros contábeis das distribuidoras, que se utilizam das taxas 
constantes da Resolução 240/2006. Essa taxa é aplicada sobre a BRR com o intuito de formar a "amortização de capital" e recompor os ativos afetos à prestação dos serviços.

De acordo com a definição apresentada pela Aneel ${ }^{81}$, a Quota de Reintegração Regulatória considera a depreciação e a amortização dos investimentos realizados visando recompor os ativos afetos à prestação do serviço ao longo da sua vida útil. Nas notas técnicas relativas às revisões tarifárias ${ }^{82}$ apresentadas pela Aneel, a informação referente ao objetivo da quota é bem resumida, não havendo detalhes sobre qual parte se refere à amortização dos investimentos e qual se refere à recomposição de ativos. Dessa forma, deixa em suspenso três itens: i) quanto deste percentual deverá ser destinado para recompor os bens, ii) quanto deverá ser destinado a amortizar capital; e iii) quanto foi amortizado de capital investido via tarifa paga pelo usuário.

Este último item pode causar efeitos no final do contrato, uma vez que a Lei das Concessões e o contrato de concessão estabelecem que será objeto de indenização a parcela dos investimentos vinculados aos bens ainda não amortizados ou depreciados ${ }^{83}$.

Sendo assim, a parcela referente à quota de reintegração, que é paga via tarifa, deve ser destinada a amortizar capital e recompor os bens da concessão, sem haver uma segregação explícita sobre o quanto deve ser destinado para cada fim.

A taxa de depreciação média utilizada como base para cálculo da quota de reintegração gira em torno de 4,5\%, de acordo com a média calculada para as empresas para o segundo ciclo tarifário (quadro 11). Enquanto as taxas de depreciação apresentadas pela Resolução 240/2006, a serem utilizadas para fins de depreciação contábil, apresentam percentuais que variam de 2,0\% (para reservatórios, barragem e adutora) a 5,9\% (para sistemas de alimentação de energia) relativos aos equipamentos de distribuição.

\footnotetext{
${ }^{81}$ Resolução Aneel 234/2006, define: "Quota de Reintegração Regulatória: quota que considera a depreciação e a amortização dos investimentos realizados, visando recompor os ativos afetos à prestação do serviço, ao longo da sua vida útil”.

${ }^{82}$ Notas Técnicas $\mathrm{n}^{\mathrm{os}}$ 025/2000-SER/ANEEL, 178/2002-SFF/ANEEL, 030/2003-SER/ANEEL, 262/2006SER/ANEEL e 353/2008-SFF/ANEEL.

${ }^{83}$ A Lei das Concessões, 8.987/1995, disciplina que no advento do termo contratual (art. 36) e a encampação durante o prazo da concessão (art. 37) considerara-se passíveis de indenização apenas as "parcelas dos investimentos vinculados a bens reversíveis, ainda não amortizados ou depreciados, que tenham sido realizados com o objetivo de garantir a continuidade e atualidade do serviço concedido".

"Art. 36. A reversão no advento do termo contratual far-se-á com a indenização das parcelas dos investimentos vinculados a bens reversíveis, ainda não amortizados ou depreciados, que tenham sido realizados com o objetivo de garantir a continuidade e atualidade do serviço concedido.

Art. 37. Considera-se encampação a retomada do serviço pelo poder concedente durante o prazo da concessão, por motivo de interesse público, mediante lei autorizativa específica e após prévio pagamento da indenização, na forma do artigo anterior.
} 
Para construção do quadro abaixo, foi utilizada a taxa média de depreciação informada pela distribuidora nas notas explicativas dos demonstrativos financeiros publicados no período de 2007. Tal taxa refere-se aos ativos imobilizados no serviço de distribuição de energia elétrica. Foram selecionadas as mesmas 15 empresas relacionadas no quadro 9. A taxa média de depreciação contábil divulgada pelos demonstrativos financeiros no ano de 2007 apresenta os seguintes valores:

Quadro 10 - Taxa média de depreciação contábil

\begin{tabular}{|l|r|}
\hline \multicolumn{1}{|c|}{ Distribuidora } & \multicolumn{1}{c|}{ TMD } \\
\hline AES-SUL & $4,60 \%$ \\
\hline CEMIG & $5,29 \%$ \\
\hline COELBA & $4,40 \%$ \\
\hline COELCE & $5,11 \%$ \\
\hline COSERN & $3,30 \%$ \\
\hline CPFL & $5,21 \%$ \\
\hline ENERGIPE & $4,60 \%$ \\
\hline ENERSUL & $3,30 \%$ \\
\hline RGE & $3,67 \%$ \\
\hline ELETROPAULO & $2,50 \%$ \\
\hline ELEKTRO & $3,30 \%$ \\
\hline BANDEIRANTE & $3,00 \%$ \\
\hline PIRATININGA & $3,30 \%$ \\
\hline CFLCL(Energisa) & $4,50 \%$ \\
\hline ESCELSA & $3,30 \%$ \\
\hline Média & $\mathbf{3 , 9 6 \%}$ \\
\hline Desvio Padrão & $\mathbf{0 , 0 1}$ \\
\hline
\end{tabular}

Fonte: Notas explicativas às demonstrações financeiras publicadas - CVM.

Pelo quadro observa-se que as taxas variam de empresa para empresa, resultando em uma média de 3,96\%, próxima à taxa média utilizada pela Aneel para cálculo da quota de reintegração.

Apresenta-se abaixo um quadro com o percentual de quota de reintegração regulatória das 15 empresas selecionadas no primeiro e segundo ciclo tarifário. 
Quadro 11 - Quota de reintegração regulatória - QRR

\begin{tabular}{|l|c|c|}
\hline \multicolumn{3}{|c|}{ Quota de Reintegração Regulatória - QRR } \\
\hline Distribuidora & 1 CICLO RT & 2 CICLO RT \\
\hline AES-SUL & $4,19 \%$ & $4,47 \%$ \\
\hline CEMIG & $4,83 \%$ & $4,66 \%$ \\
\hline COELBA & $4,76 \%$ & $4,56 \%$ \\
\hline COELCE & $4,43 \%$ & $4,43 \%$ \\
\hline COSERN & $5,23 \%$ & $4,57 \%$ \\
\hline CPFL & $4,64 \%$ & $4,55 \%$ \\
\hline ENERGIPE & $4,45 \%$ & $4,75 \%$ \\
\hline ENERSUL & $4,34 \%$ & $4,21 \%$ \\
\hline RGE & $4,60 \%$ & $4,11 \%$ \\
\hline ELETROPAULO & $4,60 \%$ & $4,70 \%$ \\
\hline ELEKTRO & $4,76 \%$ & $4,63 \%$ \\
\hline BANDEIRANTE & $4,52 \%$ & $4,62 \%$ \\
\hline PIRATININGA & $4,30 \%$ & $4,07 \%$ \\
\hline CFLCL (ENERGISA) & $4,02 \%$ & $4,69 \%$ \\
\hline ESCELSA & $4,26 \%$ & $4,57 \%$ \\
\hline Média & $\mathbf{4 , 5 3 \%}$ & $\mathbf{4 , 4 7 \%}$ \\
\hline Desvio Padrão & $\mathbf{0 , 0 0 3 0}$ & $\mathbf{0 , 0 0 2 1}$ \\
\hline Fonte: Aneel - Notas técnicas de revisão tarifária, 1ํㅜ e 2 ciclo, \\
por empresa. & & \\
Nota: RT: Revisão Tarifária. & & \\
\hline
\end{tabular}

Pelo quadro é possível observar um aumento na média das taxas de depreciação, utilizadas para cálculo da quota de reintegração, e redução do desvio padrão calculado de um ciclo para outro. A redução do desvio padrão mostra que as variáveis utilizadas apresentam valores mais próximos, por exemplo, para o segundo ciclo, significando que não são apresentados muitos valores diferentes de $4,47 \%$.

Quanto ao aumento na média da taxa de depreciação utilizada para fins regulatórios do primeiro para o segundo ciclo, nas notas utilizadas como referência para elaboração desse cálculo não foram encontradas justificativas nem menção específica a esse fato. Contudo, é possível observar que empresas que apresentavam uma taxa média abaixo de 4,5\% (como Aes-sul, CFLCL - ENERGISA) no primeiro ciclo, tiveram sua taxa média alterada para valores mais próximos de 4,5\%, e as empresas que possuíam a taxa média acima de 4,5\%, tiveram sua taxa média alterada para valores mais próximos de 4,5\%, como por exemplo, Cosern $(5,23 \%$ para 4,57$)$ e Cemig $(4,83 \%$ para $4,66 \%)$. Portanto, é possível supor que as taxas foram alteradas de maneira a apresentarem convergência para um valor próximo de $4,5 \%$.

Se compararmos a taxa utilizada pela distribuidora na depreciação do ativo nos demonstrativos contábeis com a taxa utilizada pela Aneel como quota de reintegração, apurase uma diferença que pode ser considerada como o percentual destinado à recomposição do 
capital. Como exemplo é possível citar a COSERN, onde a distribuidora apresenta nos demonstrativos contábeis uma taxa média de depreciação do imobilizado de 3,30\% (quadro 10) e quota de reintegração de $4,57 \%$ (quadro 11 - segundo ciclo), ou seja, a diferença entre esses dois percentuais é de $1,27 \%$. Com base nessa comparação, pode-se inferir que 3,30\% seria para recompor bens e 1,27\% para amortizar capital. No entanto, existem distribuidoras como a Cemig que apresentam 5,29\% de taxa média de depreciação (quadro 10) e 4,66 de quota de reintegração (quadro 11 - segundo ciclo), onde essa análise não pode ser feita.

Desse modo, é possível visualizar os ajustes feitos pela contabilidade regulatória nas informações obtidas por meio da contabilidade societária no processo tarifário para fixar a receita a ser arrecadada dos usuários, a qual garantirá o equilíbrio econômico-financeiro do contrato, quais sejam:

a) alteração do valor da base de ativos, contabilizados à custo histórico nas demonstrações financeiras publicadas, para uma base de ativos regulatórios avaliados a custo de reposição, para construir a base de remuneração regulatória, conforme evidenciado no quadro 9; e

b) alteração da taxa média de depreciação apresentada pelos demonstrativos financeiros publicados, quadro 10, para uma taxa média de depreciação regulatória, para cálculo da quota de reintegração regulatória, quadro 11.

Sobre os custos operacionais (OPEX) utilizados como componente da receita de equilíbrio, o regulador adota os custos de uma Empresa de Referência, que resultam em custos operacionais considerados eficientes e são adotados como parâmetro de incentivo para que as empresas busquem a redução do custo operacional, tendo como balizador o valor fixado no processo de revisão tarifária.

É importante ressaltar que o tema da busca da eficiência operacional pelas empresas está tratado por Tozzini (2006), citado anteriormente, que realizou um estudo sobre as estratégias adotadas durante o primeiro ciclo tarifário no que se refere aos custos operacionais e constatou que as distribuidoras promoveram mudanças moderadas em suas estratégias funcionais e específicas em função dos critérios utilizados e dos custos estabelecidos via Empresa de Referência - ER.

Isso decorre do fato de os custos operacionais com base na ER serem fixados no ano da revisão e permanecerem vigentes durante todo o ciclo tarifário (4 ou 5 anos). Assim, ao reduzir os gastos de operação abaixo dos custos operacionais fixados, a distribuidora 
automaticamente aumenta sua remuneração. E esse é um dos principais incentivos para as distribuidoras, já que esses custos estão diretamente sob sua administração.

Além disso, a sinalização dada motiva as distribuidoras a aperfeiçoarem seus processos de gestão de modo a reduzirem seus custos e, consequentemente, obter a rentabilidade prevista no processo de revisão tarifária ou até superá-la durante o período tarifário.

A descrição e análise desses parâmetros serão utilizadas para a formação da receita de equilíbrio, discutida no tópico a seguir.

\subsubsection{Formação da Receita de Equilíbrio}

Com base na análise das variáveis que compõem o CAPEX da receita de equilíbrio para os períodos tarifários, esta será então calculada para a simulação pretendida neste capítulo, considerando os seguintes critérios:

1) a BRR foi estimada em $30 \%^{84}$ superior ao Ativo Imobilizado em Serviço - AIS líquido da depreciação, tomando como referência o ano de 2002, que apresenta um saldo líquido de $\mathrm{R} \$ 860.000,00$;

2) o WACC utilizado foi o aprovado pela Aneel para o primeiro ciclo de revisão tarifária, de 11,26\% depois de impostos;

3) para cálculo da quota de reintegração regulatória foi utilizado a média da taxa média de depreciação encontrada para o primeiro ciclo de revisão tarifária, conforme quadro 11 deste trabalho, de $4,5 \%$;

4) para cálculo do OPEX foi utilizado o mesmo valor com as despesas operacionais, supondo que a distribuidora tem valor de custos operacionais idênticos aos do benchmarking fixado pela Aneel como Empresa de Referência: valor de $\mathrm{R} \$ 20.000,00$.

Assim sendo, podemos observar o cálculo da receita de equilíbrio a ser fixada para o primeiro ciclo tarifário (correspondente ao período de 2003-2007), conforme quadro abaixo.

\footnotetext{
${ }^{84}$ Foi utilizado esse percentual porque ele equivale a média apurada considerando a superioridade da Base de Remuneração Regulatória em relação ao Ativo Imobilizado publicado pelas demonstrações financeiras, para o segundo ciclo tarifário, conforme quadro 9 deste trabalho.
} 
Quadro 12 - Receita de equilíbrio - primeiro ciclo tarifário

\begin{tabular}{|lr|}
\hline \multicolumn{2}{|c|}{$\begin{array}{c}\text { Receita de Equilíbrio - Primeiro ciclo de Revisão } \\
\text { Tarifária }\end{array}$} \\
\hline \multicolumn{2}{|c|}{ R\$ mil } \\
\hline 1) BRR $(860.000 * 1,30)$ & 1.118 .000 \\
2) WACC( real) & $11,26 \%$ \\
3)Subtotal (1x2) & $\mathbf{1 2 5 . 8 8 7}$ \\
4) TMD & $4,50 \%$ \\
5)QRR (4 x 1) & $\mathbf{5 0 . 3 1 0}$ \\
\hline & $\mathbf{1 7 6 . 1 9 7}$ \\
\hline 6) CAPEX (3+5) & $\mathbf{2 0 . 0 0 0}$ \\
\hline \multicolumn{2}{|c|}{} \\
\hline 7) OPEX = despesas operacionais \\
\hline \multicolumn{2}{|c|}{ Receita total (6+7) } \\
\hline
\end{tabular}

De acordo com os parâmetros e critérios utilizados para o cálculo da receita de equilíbrio listados acima, essa resulta em um valor de R \$ 196.197,00 a ser aplicada durante o período 2003-2007 na simulação a ser realizada neste trabalho. Ou seja, esse é o montante fixado como receita teto para cobrança de tarifas.

A relação entre a Receita de Equilíbrio - RE fixada e o valor de Base de Remuneração Regulatória - BRR, para o primeiro ciclo tarifário é de 17,55\% (R \$ 196.197/R \$1.118.000), ou seja, é possível afirmar que um indicador de rentabilidade fixado no processo de revisão tarifária pode ser expresso por essa equação, chamada, a partir de agora, de indicador de rentabilidade regulatório $\left(\mathrm{IR}_{\text {reg }}\right)$ :

\section{$\mathrm{IR}_{\mathrm{reg}}=\mathrm{RE} / \mathrm{BRR}$}

Esse indicador será utilizado na análise das simulações apresentadas neste trabalho.

Para cálculo da receita de equilíbrio a ser aplicada no segundo ciclo tarifário (correspondente ao período 2008-2012), são considerados os parâmetros fixados pela Resolução Aneel 234/2006, apresentados a seguir:

1) A BRR aprovada no primeiro ciclo passa a ser chamada de base blindada. Esse nome deve-se ao fato de que os bens que compõem essa base são fixados, não passando novamente pelo processo de avaliação de ativos, sofrendo somente os efeitos de depreciação ou alguma baixa ocorrida. Para a simulação em questão, o investimento realizado em 2004 foi considerado prudente e foi considerada a baixa de ativo ocorrida no período. 
Depois disso, a base blindada ${ }^{85}$ é adicionada aos investimentos incrementais a custo de reposição ${ }^{86}$. O cálculo da BRR do segundo ciclo está detalhado e analisado no item seguinte.

Sendo assim, a BRR teve a formação conforme quadro abaixo.

Quadro 13 - Formação da base de remuneração regulatória do $2^{\circ}$ ciclo revisório

\begin{tabular}{|l|r|}
\hline 1) Base Blindada (BRR fixada no $1^{\mathrm{o}}$ ciclo) & $\mathrm{R} \$ 1.118 .000$ \\
\hline 2) Depreciação e baixas do período & $\mathrm{R} \$(195.650)$ \\
\hline 3) Base depreciada (1-2) & $\mathrm{R} \$ 922.350$ \\
\hline 4) BRR líquida & $\mathbf{R ~ 9 2 2 . 3 5 0}$ \\
\hline & \\
\hline 5) Estimação dos investimentos Incrementais & $\mathbf{R} \mathbf{1 3 0 . 0 0 0}$ \\
\hline à custo de reposição (30\% superior ao contábil) & \\
\hline & $\mathbf{R} \$ \mathbf{1 . 0 5 2 . 3 5 0}$ \\
\hline BRR 2
\end{tabular}

2) O WACC utilizado foi o aprovado pela Aneel para o segundo ciclo de revisão tarifária, de 9,95\% depois de impostos.

3) Para cálculo da quota de reintegração regulatória foi utilizada a média da taxa média de depreciação encontrada para o segundo ciclo de revisão tarifária, conforme quadro 11 deste trabalho, considerando o arredondamento de 4,47\% para $4,5 \%$.

4) Para cálculo do OPEX, no segundo ciclo tarifário, foi utilizado o mesmo valor com despesas operacionais, supondo que a distribuidora tem valor de custos operacionais idênticos aos do benchmarking fixado pela Aneel como Empresa de Referência: valor de R\$30.000,00.

Com base nessas premissas foi calculada a receita de equilíbrio para o segundo ciclo tarifário (2008-2012) que resultou num valor de $\mathrm{R} \$ 182.065,00$.

\footnotetext{
85 A base blindada é corrigida pelo IGP-M, no entanto, como nas simulações realizadas neste trabalho desconsidera-se os efeitos da inflação, esta atualização não é realizada.

${ }^{86}$ Foi utilizado o mesmo critério para fixação da BRR do primeiro ciclo tarifário dessa simulação, ou seja, a avaliação à custo de reposição para a simulação em questão resulta em um valor de $30 \%$ superior em relação ao valor do imobilizado contábil.
} 
Quadro 14 - Receita de equilíbrio - segundo ciclo de revisão tarifária

\begin{tabular}{|lr|}
\hline \multicolumn{2}{|c|}{ Receita de Equilíbrio - Segundo ciclo de Revisão } \\
Tarifária
\end{tabular}

$\mathrm{O}$ cálculo do indicador de rentabilidade regulatório - $\mathrm{IR}_{\mathrm{reg}},(\mathrm{RE} / \mathrm{BRR})$ apresenta percentual de 17,30\% $(\mathrm{R} \$ 182.065 / \mathrm{R} \$ 1.052 .350)$, para o segundo ciclo tarifário. Esse indicador teve uma ligeira redução, ao considerar os efeitos da depreciação, baixa da BRR e a redução do WACC de 12,26\%, no primeiro ciclo, para 9,95\%, no segundo ciclo.

$\mathrm{Na}$ formação da receita de equilíbrio do segundo ciclo tarifário observa-se a superioridade da base de ativos em comparação com o declínio do valor dos bens do imobilizado registrados a valor de aquisição (custo histórico).

Quadro 15 - Extrato do balanço da concessão - 1998 e 2003-2007

\begin{tabular}{|l|c|c|c|c|c|c|}
\hline & *Período Inicial & \multicolumn{5}{|c|}{ 1 Ciclo Revisório } \\
\hline BALANÇO CONCESSÃO & $\mathbf{1 9 9 8}$ & $\mathbf{2 0 0 3}$ & $\mathbf{2 0 0 4}$ & $\mathbf{2 0 0 5}$ & $\mathbf{2 0 0 6}$ & $\mathbf{2 0 0 7}$ \\
\hline Ativo Imobilizado & 1.000 .000 & 1.000 .000 & 1.070 .000 & 1.070 .000 & 1.070 .000 & 1.070 .000 \\
\hline Depreciação acumulada & - & $(140.000)$ & $(175.000)$ & $(213.500)$ & $(252.000)$ & $(290.500)$ \\
\hline Saldo líquido do AIS & 1.000 .000 & 825.000 & 856.500 & 818.000 & 779.500 & $\mathbf{7 4 1 . 0 0 0}$ \\
\hline
\end{tabular}

Nota: - Item analisado: Saldo líquido do Ativo Imobilizado em Serviço.

*o período inicial foi compactado somente para efeito de simplificação.

Enquanto a base de ativos regulatórios apresenta patamares relativamente próximos nos ciclos, $\mathrm{R} \$ 1.118 .000,00$ e $\mathrm{R} \$ 1.406 .311$, para primeiro e segundo ciclo tarifário, respectivamente, o ativo imobilizado líquido vai sendo depreciado, conforme os critérios de depreciação, e apresenta em 2007 um saldo de: R\$ 741.000,00. O WACC regulatório em função dos ajustes comentados no item 3.3.4.2.2 apresenta redução de, aproximadamente, 1,31 pontos percentuais. 
Os OPEX estimados como empresa de referência apresentam saldo estimado de $\mathrm{R} \$$ $30.000,00$ e para a análise do trabalho representa o mesmo valor como despesas operacionais incorridas.

A formação da receita de equilíbrio nos dois ciclos tarifários, apresentada acima, demonstra a formação de uma base de ativos regulatórios diferente do ativo imobilizado apresentado pelos demonstrativos financeiros publicados, e uma taxa média de depreciação diferente da apresentada nas notas explicativas às demonstrações financeiras.

Esses ajustes são feitos para atender aos objetivos da regulação tarifária sendo realizados de acordo com o estabelecido nas normas que sustentam o modelo de regulação adotado no Brasil.

Sendo assim, uma vez fixada a receita que confere equilíbrio econômico-financeiro ao contrato, em forma de CAPEX e OPEX, surge a seguinte questão: é possível identificar esse equilíbrio via demonstrações financeiras? Para essa análise, a seguir apresenta-se a simulação do contrato de concessão de acordo com o modelo societário atual.

\subsection{SIMULAÇÃO DAS DEMONSTRAÇÕES FINANCEIRAS DE UM CONTRATO DE CONCESSÃO DE ACORDO COM O MODELO SOCIETÁRIO ATUAL}

Após a descrição dos componentes da receita de equilíbrio, passa-se a seguir para a simulação das demonstrações financeiras de um contrato de concessão realizada de acordo com o modelo societário atual.

A simulação observa os parâmetros elencados na parte inicial deste Capítulo e contempla a realização de duas revisões tarifárias com a estipulação de nova receita de equilíbrio, conforme demonstrado no item 4.2.1, além de novos investimentos em ativos em decorrência de obsolescência ou de expansão da base de usuários.

A determinação da receita tarifária periódica segue o estabelecido no contrato de concessão, conforme detalhado no item 3.3 deste trabalho.

Dessa forma, os reflexos da evolução do contrato no período 1998 a 2018 podem ser visualizados no quadro a seguir: 
Quadro 16 - Demonstrativos financeiros - modelo societário atual

\begin{tabular}{|c|c|c|c|c|c|c|c|c|c|c|c|c|c|}
\hline \multirow[b]{2}{*}{ BALANÇO CONCESSÃO } & \multicolumn{2}{|c|}{ Período Inicial* } & \multicolumn{5}{|c|}{$1^{0}$ Ciclo Revisório } & \multicolumn{5}{|c|}{$2^{\circ}$ Ciclo Revisório } & \multirow{2}{*}{$\begin{array}{c}*_{\text {Fim }} \\
2018\end{array}$} \\
\hline & 1998 & 2002 & 2003 & 2004 & 2005 & 2006 & 2007 & 2008 & 2009 & 2010 & 2011 & 2012 & \\
\hline \multicolumn{14}{|l|}{ ATIVO } \\
\hline Caixa & & 370.400 & 546.597 & 622.794 & 798.990 & 975.187 & 1.151 .384 & 1.303 .449 & 1.305 .513 & 1.457 .578 & 1.609 .642 & 1.761 .707 & 2.674 .094 \\
\hline Ativo Imobilizado & 1.000 .000 & 1.000 .000 & 1.000 .000 & 1.070 .000 & 1.070 .000 & 1.070 .000 & 1.070 .000 & 1.070 .000 & 1.220 .000 & 1.220 .000 & 1.220 .000 & 1.220 .000 & 1.220 .000 \\
\hline Investimentos (adições) & & - & - & 100.000 & - & - & - & - & 150.000 & - & - & - & - \\
\hline 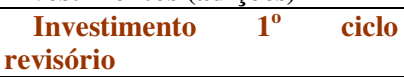 & & & - & 100.000 & - & - & - & - & - & - & - & - & - \\
\hline $\begin{array}{lll}\begin{array}{l}\text { Investimento } \\
\text { revisório }\end{array} & 2^{0} & \text { ciclo } \\
\end{array}$ & & & & & & & & - & 150.000 & - & - & - & - \\
\hline Depreciação acumulada & - & $(105.000)$ & $(140.000)$ & $(175.000)$ & $(213.500)$ & $(252.000)$ & $(290.500)$ & $(329.000)$ & $(367.500)$ & $(411.250)$ & $(455.000)$ & $(498.750)$ & $(761.250)$ \\
\hline Depreciação do ano & & $(35.000)$ & $(35.000)$ & $(38.500)$ & $(38.500)$ & $(38.500)$ & $(38.500)$ & $(38.500)$ & $(43.750)$ & $(43.750)$ & $(43.750)$ & $(43.750)$ & $(43.750)$ \\
\hline Saldo líquido do AIS & 1.000 .000 & 860.000 & 825.000 & 856.500 & 818.000 & 779.500 & 741.000 & 702.500 & 808.750 & 765.000 & 721.250 & 677.500 & 415.000 \\
\hline TOTAL DO ATIVO & 1.000 .000 & 1.230 .400 & 1.371.597 & 1.479.294 & 1.616 .990 & 1.754.687 & 1.892.384 & 2.005 .949 & 2.114 .263 & 2.222.578 & 2.330 .892 & 2.439.207 & 3.089.094 \\
\hline \multicolumn{14}{|l|}{ Passivo } \\
\hline Patrimônio Líquido & 1.000 .000 & 1.230 .400 & 1.371 .597 & 1.479 .294 & 1.616 .990 & 1.754 .687 & 1.892 .384 & 2.005 .949 & 2.114 .263 & 2.222 .578 & 2.330 .892 & 2.439 .207 & 3.089 .094 \\
\hline Cap. Social & 1.000 .000 & 1.000 .000 & 1.000 .000 & 1.000 .000 & 1.000 .000 & 1.000 .000 & 1.000 .000 & 1.000 .000 & 1.000 .000 & 1.000 .000 & 1.000 .000 & 1.000 .000 & 1.000 .000 \\
\hline Lucros/Prejuízos acumulados & & 172.800 & 230.400 & 371.597 & 479.294 & 616.990 & 754.687 & 892.384 & 1.005 .949 & 1.114 .263 & 1.222 .578 & 1.330 .892 & 1.980 .780 \\
\hline TOTAL DO PASSIVO & 1.000 .000 & 1.230 .400 & 1.371.597 & 1.479 .294 & 1.616 .990 & 1.754 .687 & 1.892 .384 & 2.005 .949 & 2.114 .263 & 2.222 .578 & 2.330 .892 & 2.439 .207 & 3.089 .094 \\
\hline \multicolumn{14}{|l|}{ DRE } \\
\hline Receita tarifária & - & 112.600 & 196.197 & 196.197 & 196.197 & 196.197 & 196.197 & 182.065 & 182.065 & 182.065 & 182.065 & 182.065 & 182.065 \\
\hline Despesa operacional & - & $(20.000)$ & $(20.000)$ & $(20.000)$ & $(20.000)$ & $(20.000)$ & $(20.000)$ & $(30.000)$ & $(30.000)$ & $(30.000)$ & $(30.000)$ & $(30.000)$ & $(30.000)$ \\
\hline Despesa não operacional (baixa) & & & & $(30.000)$ & & & & & & & & & \\
\hline Despesa depreciação & - & $(35.000)$ & $(35.000)$ & $(38.500)$ & $(38.500)$ & $(38.500)$ & $(38.500)$ & $(38.500)$ & $(43.750)$ & $(43.750)$ & $(43.750)$ & $(43.750)$ & $(43.750)$ \\
\hline Resultado do Exercício & - & 57.600 & 141.197 & 107.697 & 137.697 & 137.697 & 137.697 & 113.565 & 108.315 & 108.315 & 108.315 & 108.315 & 108.315 \\
\hline \multicolumn{14}{|l|}{ FLUXO DE CAIXA } \\
\hline Caixa inicial & & 277.800 & 370.400 & 546.597 & 622.794 & 798.990 & 975.187 & 1.151 .384 & 1.303 .449 & 1.305 .513 & 1.457 .578 & 1.609 .642 & 2.522 .030 \\
\hline Recebimento de tarifas & & 112.600 & 196.197 & 196.197 & 196.197 & 196.197 & 196.197 & 182.065 & 182.065 & 182.065 & 182.065 & 182.065 & 182.065 \\
\hline Realização de Investimento & & & & $(100.000)$ & - & - & - & - & $(150.000)$ & - & - & - & \\
\hline Despesa operacional & & $(20.000)$ & $(20.000)$ & $(20.000)$ & $(20.000)$ & $(20.000)$ & $(20.000)$ & $(30.000)$ & $(30.000)$ & $(30.000)$ & $(30.000)$ & $(30.000)$ & $(30.000)$ \\
\hline Caixa final & & 370.400 & 546.597 & 622.794 & 798.990 & 975.187 & 1.151.384 & 1.303 .449 & 1.305 .513 & 1.457 .578 & 1.609 .642 & 1.761 .707 & 2.674 .094 \\
\hline
\end{tabular}

Nota: - Principais pontos analisados: ativo imobilizado líquido, despesa de depreciação; *O período inicial compreende os anos 1998 a 2002 que foi compactado para efeito de simplificação. A partir do ano de 2013 todas as variáveis são replicadas ocorrendo apenas sua evolução. A despesa não operacional (DRE) refere-se à baixa realizada referente ao ativo obsoleto. 
Os pontos a serem analisados nas simulações das demonstrações acima são: a evolução do ativo imobilizado em decorrência do investimento inicial, novos investimentos e os efeitos da depreciação.

\subsubsection{Evidenciação do Ativo, sua evolução e investimentos realizados}

No que se refere ao ativo imobilizado, sua evolução e respectiva depreciação no prazo da concessão (20 anos) podem ser visualizadas no quadro abaixo.

Quadro 17 - Extrato do balanço da concessão - ativo imobilizado

\begin{tabular}{|l|c|c|c|c|c|c|c|}
\hline & \multicolumn{2}{|c|}{ Período Inicial* } & \multicolumn{5}{|c|}{$\mathbf{1}^{\mathbf{0}}$ Ciclo Revisório } \\
\hline BALANÇO CONCESSÃO & $\mathbf{1 9 9 8}$ & $\mathbf{2 0 0 2}$ & $\mathbf{2 0 0 3}$ & $\mathbf{2 0 0 4}$ & $\mathbf{2 0 0 5}$ & $\mathbf{2 0 0 6}$ & $\mathbf{2 0 0 7}$ \\
\hline Ativo Imobilizado & 1.000 .000 & 1.000 .000 & 1.000 .000 & 1.070 .000 & 1.070 .000 & 1.070 .000 & 1.070 .000 \\
\hline Investimentos (adições) & & - & - & 100.000 & - & - & - \\
\hline Depreciação acumulada & - & $(105.000)$ & $(140.000)$ & $(175.000)$ & $(213.500)$ & $(252.000)$ & $(290.500)$ \\
\hline \multicolumn{1}{|c|}{ Saldo líquido do AIS } & 1.000 .000 & 860.000 & 825.000 & 856.500 & 818.000 & 779.500 & 741.000 \\
\hline
\end{tabular}

Nota: *compacta-se o período inicial apenas para simplificação.

Continuação do Quadro 17 - Extrato do balanço da concessão - ativo imobilizado

\begin{tabular}{|l|c|c|c|c|c|c|}
\hline & \multicolumn{5}{|c|}{$\mathbf{2}^{\circ}$ Ciclo Revisório } & \multicolumn{2}{c|}{ Fim } \\
\hline BALANÇO CONCESSÃO & $\mathbf{2 0 0 8}$ & $\mathbf{2 0 0 9}$ & $\mathbf{2 0 1 0}$ & $\mathbf{2 0 1 1}$ & $\mathbf{2 0 1 2}^{*}$ & $\mathbf{2 0 1 8}$ \\
\hline Ativo Imobilizado & 1.070 .000 & 1.220 .000 & 1.220 .000 & 1.220 .000 & 1.220 .000 & 1.220 .000 \\
\hline Investimentos (adições) & - & 150.000 & - & - & - & - \\
\hline Depreciação acumulada & $(329.000)$ & $(367.500)$ & $(411.250)$ & $(455.000)$ & $(498.750)$ & $(761.250)$ \\
\hline Saldo líquido do AIS & 702.500 & 808.750 & 765.000 & 721.250 & 677.500 & 415.000 \\
\hline
\end{tabular}

Nota: *omite-se o período de 2013 a 2017 apenas para simplificação.

Esses quadros demonstram que os registros dos fatos econômicos ocorridos na assinatura do contrato (investimento inicial) e na realização de novos investimentos estão calcados em ativos físicos. A pergunta que deve nortear a análise é se esse ativo imobilizado representa o direito que a distribuidora adquire e reflete a essência econômica das transações ocorridas.

Na simulação apresentada, observa-se a aplicação de uma taxa de depreciação dos ativos de 3,5\%, mas isso não reflete a redução do direito adquirido no contrato de concessão, o direito de exploração, e sim a depreciação dos bens físicos à disposição do serviço de distribuição de energia elétrica.

A evolução do ativo demonstra a redução da vida útil do bem físico pela depreciação, o que não representa a redução de valor do "bem" adquirido no contrato, uma vez que a 
distribuidora não tem propriedade sobre esses bens, não podendo vendê-los ou cedê-los em garantia sem a prévia anuência do regulador.

Pode-se observar pela análise do demonstrativo acima que durante a vida do contrato, os investimentos realizados são imobilizados e, consequentemente, depreciados, resultando ao final do contrato em um ativo imobilizado líquido de $\mathrm{R} \$ 415.000$, ou seja, o direito adquirido no contrato foi a posse desses bens físicos durante os 20 anos da concessão e ao final do contrato estes apresentam um resíduo contábil.

No primeiro ciclo tarifário, compreendido pelo período 2003-2007, ocorrem investimentos incrementais no ativo imobilizado no valor de $\mathrm{R} \$ 100.000,00$ e a baixa correspondente a $\mathrm{R} \$ 30.000,00$ referente à substituição de ativos obsoletos.

A ativação e baixa de tal investimento estão expressas no quadro a seguir, onde se demonstra como se processaria o registro desses fatos econômicos via sistema contábil de modo a permitir o controle do regulador.

Quadro 18 - Ativação e baixa do investimento realizado no ano de 2004

\begin{tabular}{|l|}
\hline \multicolumn{2}{|c|}{ Investimento 10 ciclo revisório } \\
\hline \multicolumn{2}{|c|}{ (substituição) } \\
\hline \multicolumn{2}{|c|}{ Contabilização } \\
\hline \multicolumn{2}{|c|}{ Baixa do reforço a ser substituído } \\
\hline \multicolumn{2}{|c|}{ TMDC Média } \\
\hline Valor Contábil de Imobilizado Baixado (estimado) \\
\hline a Imobilizado \\
\hline \multicolumn{2}{|c|}{$30.000,00$} \\
\hline Depreciação acumulada \\
\hline a valor contábil de Imob Baixado \\
\hline Valor Residual \\
\hline \multicolumn{2}{|c|}{ Ativação } \\
\hline Imobilizado \\
\hline a Caixa \\
\hline \multicolumn{2}{|c|}{ Depreciação } \\
\hline
\end{tabular}

Conforme descrito no Capítulo 2 deste trabalho, no item que trata do Manual de Contabilidade do Serviço Público de Energia Elétrica - MCSPEE, a ativação e desativação dos 
bens do imobilizado segue uma sistema de ordens em curso, para que estes estejam sob controle e fiscalização do poder concedente.

Assim, na substituição de bens, o que ocorre é a inclusão de um ativo novo por meio de uma Ordem de Imobilização - ODI e, concomitantemente, a baixa do ativo obsoleto por meio de uma Ordem de Desativação - ODD.

Para o segundo ciclo tarifário, período 2008-2012, ocorre em 2009 a realização de um investimento no valor de $\mathrm{R} \$ 150.000,00$ relativo a novas instalações decorrentes da expansão da demanda de energia na área de concessão da distribuidora em questão.

Quadro 19 - Ativação do investimento realizado no ano de 2009

\begin{tabular}{|l|c|}
\hline \multicolumn{3}{|c|}{ Investimento 2- ciclo revisório } \\
\hline \multicolumn{2}{|c|}{ (instalação) } \\
\hline 1) Investimento & $\mathbf{1 5 0 . 0 0 0 , 0 0}$ \\
\hline TMDC Média & $\mathbf{3 , 5 0 \%}$ \\
\hline \multicolumn{2}{|c|}{ Ativação } \\
\hline Imobilizado \\
\hline a Caixa \\
\hline \multicolumn{2}{|c|}{} \\
\hline Despesa de depreciação \\
\hline a Deprec. Acumulada \\
\hline
\end{tabular}

O procedimento de ativação obedece ao estabelecido no MCSPEE, sendo ativado por meio de uma Ordem de Imobilização - ODI, passando a fazer parte dos bens contabilizados como ativo imobilizado da distribuidora e passando a ser depreciado pelos critérios de depreciação linear, obedecendo as taxas estabelecidas regulatoriamente. Não há baixa pois tratase de uma nova instalação.

O que se pretende com essa demonstração de ativação de bens é reforçar que os novos investimentos realizados na concessão passam a integrar o Ativo Imobilizado em Serviço (AIS) e são depreciados segundo as regras do MCSPEE por depreciação linear observadas as taxas estabelecidas pela Resolução 240/2006.

Nota-se, portanto, que o órgão regulador exerce pleno controle sobre o patrimônio da distribuidora, especialmente sobre o ativo de uso na prestação do serviço concedido, seja na inclusão ou baixa de bens, ou na aplicação dos critérios de depreciação. Esse controle tem como base ferramentas obtidas por meio da contabilidade regulatória. 
É importante ressaltar que os investimentos realizados na concessão só serão objeto de remuneração se forem entendidos pelo regulador como investimentos prudentes. Replica-se abaixo uma consideração recorrente nas notas de revisão tarifária sobre o tema:

\begin{abstract}
Assim, é preciso definir se o "investimento" a ser remunerado está ou não relacionado com os ativos existentes e necessários para a prestação do serviço regulado, pois a opção resultará num valor diferente para a base de remuneração e, conseqüentemente, em valores diferentes para as tarifas que serão cobradas dos consumidores. Outra ordem de consideração diz respeito à definição do que se considera "investimento prudente" que se trata de preocupação fundamental do órgão regulador no cumprimento de seus principais objetivos, quais sejam: i) zelar pelo equilíbrio nas relações entre consumidores e distribuidoras; ii) garantir tarifas justas; iii) garantir a continuidade da prestação dos serviços; iv) zelar pela qualidade do serviço; e v) atrair investimentos (Nota Técnica 353/2006-SFF-SRE/ANEEL).
\end{abstract}

A respeito dos investimentos entendidos pelo regulador como prudentes, cabe ressaltar que essa análise é sempre posterior à ativação do bem, ou seja, se na análise do investimento o regulador entende que o investimento realizado não seria necessário para a continuidade, qualidade e atualidade do serviço, e, no entanto, o investimento já foi efetivamente realizado, este passa a fazer parte do ativo imobilizado da distribuidora sem compor, contudo, a base de remuneração regulatória.

Nota-se que com o aumento dos investimentos, o grupo ativo imobilizado também vai aumentando, o que demonstra mais uma vez a clara relação com os bens físicos. Também observa-se que, ao realizar investimentos considerados prudentes pelo regulador, esses passam a compor a Base de Remuneração Regulatória - BRR e, dessa forma, aumentam a receita tarifária a ser auferida pela distribuidora.

Feitas essas considerações, em 2018, o que deveria evidenciar o ativo adquirido no contrato, tendo em vista o término de seu prazo de vigência? O ativo adquirido poderia estar liquidado, uma vez que o direito do concessionário relativo à concessão acabou. Ou seja, o ativo registrado deveria contemplar o quanto de direito a distribuidora ainda tem em relação ao que foi pactuado no contrato e não a depreciação de bens físicos, uma vez que estes pertencem à concessão e não à distribuidora.

Pode-se também inferir o interesse estatal sobre o resíduo contábil relativo a ativos não completamente depreciados ao final do contrato de concessão, visto que neste momento ocorreria sua reversão ao poder público concedente.

Feita essa análise do ativo adquirido e sua evolução de acordo com o que evidencia o modelo societário atual passa-se para a análise do equilíbrio econômico-financeiro após a revisão tarifária. 


\subsubsection{Visualização do Equilíbrio Econômico-Financeiro - EEF após a revisão tarifária}

A análise da visualização do EEF está baseada no evento econômico da revisão tarifária periódica com o contorno de formação da receita tarifária e como instrumento de manutenção do equilíbrio econômico-financeiro.

Note-se que é a revisão tarifária que permite o equilíbrio previsto no contrato, pois possibilita a adequação dos valores cobrados dos usuários de forma que se obtenha a remuneração e amortização do capital investido, além da cobertura dos custos de operação. As revisões visam apurar novos valores considerando as alterações na estrutura de custos e de mercado da distribuidora e os estímulos à eficiência e à modicidade das tarifas.

Para a análise do equilíbrio, utiliza-se aqui a visão apresentada por Guena et alli (2001), a qual diz que a análise do equilíbrio do contrato de concessão pode concentrar-se na comparação entre custos e receitas da distribuidora e que um indicador equivalente do equilíbrio econômicofinanceiro de um negócio é dado pela comparação entre a taxa interna de retorno (TIR) e o custo de capital do projeto, e um indicador de rentabilidade regulatória sobre o investimento considerado e o indicador de rentabilidade conhecido como Retorno sobre Investimento - ROI, em sua formulação analítica.

Dessa forma, a seguir será demonstrada a taxa interna de retorno apurada por um modelo de fluxo de caixa livre utilizado pela Aneel para fixação do Fator $\mathrm{X}^{87}$ no primeiro ciclo tarifário e até julho de $2008^{88}$.

Para a montagem do fluxo de caixa considerou-se que os períodos a serem analisados serão coincidentes aos períodos relativos aos ciclos tarifários. Assim, são consideradas as receitas e despesas relativas a esse período de acordo com as especificações da simulação demonstradas na DRE. Como simplificação, considerou-se que os investimentos realizados antes de 2003 não afetaram a condição de EEF, sendo o ativo imobilizado líquido no início dos ciclos (2003 e 2008, primeiro e segundo ciclo, respectivamente) considerado como investimento inicial. Assim, o período de análise do fluxo de caixa é o compreendido entre 2003-2007 e 20082012.

\footnotetext{
${ }^{87}$ Segundo a Aneel, (Nota Técnica 350/2007-SRE/ANEEL), o índice denominado Fator X, refere-se a um redutor aplicado sobre o indexador (IGPM) de modo a refletir os ganhos de produtividade de uma indústria de rede caracterizada por suas economias de escala, nos reajustes tarifários. Do período das privatizações, o valor de $\mathrm{X}$ foi fixado pela Aneel igual a zero. A partir de 2003, foi fixado valor de X para cada distribuidora. O Fator X, aplicado no reajuste tarifário anual, como redutor do IGPM, implica que as tarifas poderão ser corrigidas abaixo (e eventualmente acima) daquele indexador, caracterizando ganhos de produtividade de uma empresa regulada para os consumidores.

${ }^{88}$ Foi apresentado o processo de reajustes no item 3.3.1 deste trabalho.
} 
De acordo com os resultados das demonstrações financeiras elaboradas com base no modelo societário atual, obtêm-se os fluxos de caixa do primeiro e segundo período tarifário e calcula-se uma taxa interna de retorno - TIR, conforme demonstrado abaixo.

Quadro 20 - Fluxo de caixa do período 2003-2007

\begin{tabular}{|c|c|c|c|c|c|c|}
\hline \multirow[b]{2}{*}{ FLUXO DE CAIXA } & \multicolumn{6}{|c|}{$1^{\circ}$ CICLO REVISÓRIO } \\
\hline & Início & 2003 & 2004 & 2005 & 2006 & 2007 \\
\hline 1) Receita Tarifária & & 196.197 & 196.197 & 196.197 & 196.197 & 196.197 \\
\hline 2) Despesas Operacionais Totais & & $(55.000)$ & $(58.500)$ & $(58.500)$ & $(58.500)$ & $(58.500)$ \\
\hline 2.1) Despesas Operacionais & & $(20.000)$ & $(20.000)$ & $(20.000)$ & $(20.000)$ & $(20.000)$ \\
\hline 2.2) Depreciação dos Ativos & & $(35.000)$ & $(38.500)$ & $(38.500)$ & $(38.500)$ & $(38.500)$ \\
\hline 3) Investimentos & - & - & $(100.000)$ & - & - & - \\
\hline$=$ Resultado & - & 141.197 & 37.697 & 137.697 & 137.697 & 137.697 \\
\hline Investimentos & 860.000 & & & & & 741.000 \\
\hline Depreciação dos Ativos & - & 35.000 & 38.500 & 38.500 & 38.500 & 38.500 \\
\hline Fluxo de caixa livre* & $(860.000)$ & 176.197 & 76.197 & 176.197 & 176.197 & 917.197 \\
\hline Rentabilidade Anual & & $17,11 \%$ & $4,40 \%$ & $16,83 \%$ & $17,66 \%$ & $18,58 \%$ \\
\hline
\end{tabular}

\begin{tabular}{l|l} 
TIR Primeiro ciclo revisório & $15,83 \%$ \\
\hline
\end{tabular}

Nota: - Principais pontos analisados: receita tarifária e taxa interna de retorno.

*valores utilizados no cálculo da taxa interna de retorno.

Quadro 21 - Fluxo de caixa da concessão 2008-2012

\begin{tabular}{|c|c|c|c|c|c|c|}
\hline & \multicolumn{6}{|c|}{2 CICLO REVISÓRIO } \\
\hline FLUXO DE CAIXA & Início & 2008 & 2009 & 2010 & 2011 & 2012 \\
\hline 1) Receita Tarifária & & 182.065 & 182.065 & 182.065 & 182.065 & 182.065 \\
\hline 2) Despesas Operacionais Totais & & $(68.500)$ & $(73.750)$ & $(73.750)$ & $(73.750)$ & $(73.750)$ \\
\hline 2.1) Despesas Operacionais & & $(30.000)$ & $(30.000)$ & $(30.000)$ & $(30.000)$ & $(30.000)$ \\
\hline 2.2) Depreciação dos Ativos & & $(38.500)$ & $(43.750)$ & $(43.750)$ & $(43.750)$ & $(43.750)$ \\
\hline 3) Investimentos & & - & $(150.000)$ & - & - & - \\
\hline$=$ Resultado & & 113.565 & $(41.685)$ & 108.315 & 108.315 & 108.315 \\
\hline Investimentos & 741.000 & & & & & 677.500 \\
\hline Depreciação dos Ativos & & 38.500 & 43.750 & 43.750 & 43.750 & 43.750 \\
\hline Fluxo de caixa livre* & $(741.000)$ & 152.065 & 2.065 & 152.065 & 152.065 & 829.565 \\
\hline Rentabilidade Anual & & $16,17 \%$ & $-5,15 \%$ & $14,16 \%$ & $15,02 \%$ & $15,99 \%$ \\
\hline TIR segundo período revisório & $14,69 \%$ & & & & & \\
\hline
\end{tabular}

Nota: - Principais pontos analisados: receita tarifária e taxa interna de retorno.

*valores utilizados no cálculo da taxa interna de retorno.

Os valores que resultam na linha fluxo de caixa livre têm como base os valores extraídos da Demonstração de Resultado do Exercício - DRE, do modelo societário atual. Pela simulação 
apresentada, para o primeiro ciclo tarifário a TIR calculada é de 15,83\%, acima do custo de capital fixado pela Aneel para as distribuidoras, que foi de 11,26\% antes de impostos.

Isso significa que na comparação indicada por Guena et alli (2001), TIR versus WACC regulatório, o resultado do período analisado demonstra uma situação de desequilíbrio em favor da distribuidora.

Contudo, como nos valores utilizados para apuração da TIR, considera-se o efeito da depreciação no fluxo de caixa. A soma desse valor ao resultado distorce a comparação TIR x WACC, uma vez que o WACC é aplicado sobre a BRR e só depois é adicionado à QRR, não podendo assim ser o único balizador para a análise pretendida. Além disso, os valores utilizados para o fluxo de caixa extraídos das demonstrações não coincidem com os valores utilizados pelo regulador.

Dessa forma, entende-se que uma outra comparação possível de ser realizada com a TIR é o indicador de rentabilidade regulatória, fixado como $\operatorname{IR}_{\text {reg }}(\mathrm{RE} / \mathrm{BRR})$ apurado na fixação da receita de equilíbrio nos períodos tarifários.

$\mathrm{O}$ indicador de rentabilidade regulatório fixado pelo Regulador, para o primeiro ciclo, de $17,55 \%$, supera a TIR apurada no período, de $15,83 \%$. No segundo ciclo o indicador de rentabilidade ( $\mathrm{IR}_{\mathrm{reg}}$ ) é de 17,30\% em comparação com a TIR apurada para o mesmo período, de 14,69\%. Essa diferença pode ser explicada pela realização de investimentos no período.

Na hipótese da "não realização dos investimentos" a TIR apurada no primeiro período seria de $18,58 \%$, conforme pode ser observado abaixo.

Quadro 22 - Fluxo de caixa da concessão 2003-2008 - sem investimentos adicionais

\begin{tabular}{|l|c|c|c|c|c|c|}
\hline \multicolumn{1}{|c|}{ FLUXO DE CAIXA } & \multicolumn{7}{|c|}{ I CICLO REVISÓRIO } \\
\hline 1) Receita Tarifária & $\mathbf{2 0 0 3}$ & $\mathbf{2 0 0 4}$ & $\mathbf{2 0 0 5}$ & $\mathbf{2 0 0 6}$ & $\mathbf{2 0 0 7}$ \\
\hline 2) Despesas Operacionais Totais & & 196.197 & 196.197 & 196.197 & 196.197 & 196.197 \\
\hline 2.1) Despesas Operacionais & & $(55.000)$ & $(55.000)$ & $(55.000)$ & $(55.000)$ & $(55.000)$ \\
\hline 2.2) Depreciação dos Ativos & & $\mathbf{( 3 5 . 0 0 0 )}$ & $\mathbf{( 3 5 . 0 0 0 )}$ & $(\mathbf{3 5 . 0 0 0})$ & $(\mathbf{3 5 . 0 0 0 )}$ & $\mathbf{( 3 5 . 0 0 0 )}$ \\
\hline & & & & & & \\
\hline $\mathbf{3}$ Investimentos & - & - & & - & - & - \\
\hline & & & & & & \\
\hline = Resultado & - & $\mathbf{1 4 1 . 1 9 7}$ & $\mathbf{1 4 1 . 1 9 7}$ & $\mathbf{1 4 1 . 1 9 7}$ & $\mathbf{1 4 1 . 1 9 7}$ & $\mathbf{1 4 1 . 1 9 7}$ \\
\hline Investimentos & 860.000 & & & & & 741.000 \\
\hline Depreciação dos Ativos & - & 35.000 & 35.000 & 35.000 & 35.000 & 35.000 \\
\hline Fluxo de caixa livre & $\mathbf{( 8 6 0 . 0 0 0 )}$ & $\mathbf{1 7 6 . 1 9 7}$ & $\mathbf{1 7 6 . 1 9 7}$ & $\mathbf{1 7 6 . 1 9 7}$ & $\mathbf{1 7 6 . 1 9 7}$ & $\mathbf{9 1 7 . 1 9 7}$ \\
\hline & & & & & & \\
\hline Rentabilidade Anual & & $17,11 \%$ & $16,49 \%$ & $17,26 \%$ & $18,11 \%$ & $19,05 \%$ \\
\hline & & & & & & \\
\hline TIR Primeiro ciclo revisório & $\mathbf{1 8 , 5 8 \%}$ & & & & & \\
\hline
\end{tabular}

Nota: - Item a ser analisado: fluxo de caixa sem realização de investimentos e impacto na TIR. 
A TIR apurada pelo fluxo de caixa sem realização de investimentos $(18,58 \%)$ apresenta um aumento em torno de dois pontos percentuais em relação ao fluxo com investimento $(15,83 \%)$. Para o segundo ciclo, sem considerar os investimentos, a TIR apurada é de 19,36\%, apresentando aumento de cinco pontos percentuais em relação ao fluxo com investimentos $(14,69 \%)$.

Isso vem demonstrar que a "não realização dos investimentos" faria com que o indicador de rentabilidade $\left(\mathrm{IR}_{\text {reg }}\right)$ apurado no primeiro ciclo $(17,55 \%)$ e a TIR sem investimento $(18,58 \%)$ ficassem próximos, o que pode ser visto também no segundo ciclo, onde $\operatorname{IR}_{\text {reg }}=17,30 \%$ e $\mathrm{TIR}=$ $19,39 \%$ ( sem investimentos).

Contudo, se estes investimentos forem entendidos como prudentes pelo regulador, estes passam a compor a Base de Remuneração e aumentam a receita tarifária recebida pela distribuidora a partir da próxima revisão tarifária.

A esse respeito, nota-se ainda que a quota de reintegração regulatória apresenta como finalidade a recomposição de bens físicos, ou seja, uma parte do que é cobrado nas tarifas é para constituir um “funding” para realização de investimentos durante o período tarifário. Só não é possível identificar o quanto da quota é destinado a isso, conforme discutido anteriormente.

Feitas essas considerações sobre os investimentos adicionais, toma-se a seguir as demonstrações como base para o cálculo de um indicador, o ROI (Retorno sobre o Investimento) em sua formulação analítica.

Quadro 23 - Formulação analítica do ROI

\begin{tabular}{|c|c|c|c|c|c|c|c|c|c|c|c|}
\hline & \multicolumn{11}{|c|}{ Formulação analítica do desempenho medido pelo ROI } \\
\hline & & 2003 & 2004 & 2005 & 2006 & 2007 & 2008 & 2009 & 2010 & 2011 & 2012 \\
\hline Margem & $\underline{\text { Resultado }}$ & $72 \%$ & $55 \%$ & $70 \%$ & $70 \%$ & $70 \%$ & $62 \%$ & $60 \%$ & $60 \%$ & $60 \%$ & $60 \%$ \\
\hline R्OI & ROI $=$ & $17,11 \%$ & $12,57 \%$ & $16,83 \%$ & $17,66 \%$ & $18,58 \%$ & $16,17 \%$ & $13,39 \%$ & $14,16 \%$ & $15,02 \%$ & $15,99 \%$ \\
\hline Giro & $\mathrm{RT}^{*}$ & $24 \%$ & $23 \%$ & $24 \%$ & $25 \%$ & $26 \%$ & $26 \%$ & $23 \%$ & $24 \%$ & $25 \%$ & $27 \%$ \\
\hline
\end{tabular}

Nota: *Receita Tarifária; **Investimentos representados pelo Ativo Imobilizado Líquido.

A análise desse indicador aponta que a distribuidora tem um Retorno sobre o Investimento de $17,11 \%$ em 2003 , no momento da fixação da receita de equilíbrio e atravessa o primeiro ciclo com esse indicador variando em patamares de 16,83\% em 2005, alcançando $18,58 \%$ no último ano do ciclo, em 2007. Para o período tarifário seguinte (2008-2012) esse 
indicador inicia com percentual de 16,17\%, variando de 13,39\% a 15,99\%. Para o segundo ciclo esse indicador não supera a rentabilidade inicial devido ao efeito do investimento realizado em 2009, que atenua o efeito da depreciação, elevando o Giro para $27 \%$.

Os reflexos dos investimentos realizados nos períodos podem ser vistos com a redução do indicador nos anos de 2004 e 2009.

Observa-se que a rentabilidade medida por esse indicador no final do primeiro ciclo tarifário - 2007 (onde, ROI = 18,58\%) supera a rentabilidade fixada no início dos ciclos 2003 (onde ROI $=17,11 \%$ ). Isso decorre do efeito da depreciação nos investimentos (representados pelo Ativo Imobilizado, denominador da fórmula do Giro). Para o segundo ciclo, o ROI apresenta em 2012 um percentual de 15,99\%, abaixo do ROI apurado no primeiro ano do ciclo, de $16,17 \%$. \%. Isso pode ser atribuído ao resultado da DRE, o qual não retornou ao patamar inicial, em função do aumento da depreciação dos novos investimentos.

É dessa forma que pode ser observado o EEF fixado nas revisões tarifárias via demonstrativo societário atual, antes de 2007.

Pergunta-se, então, se o investimento que está sendo remunerado e a amortização do ativo deveriam ser evidenciados pelas demonstrações financeiras? Seria possível identificar o EEF fixado nas demonstrações financeiras atuais? Para responder é preciso refletir que o que se busca ao alterar o modelo societário vigente para um modelo de acordo com padrões internacionais é a evidenciação da "essência sob a forma", ou seja, a essência econômica da transação ocorrida.

Pelos demonstrativos elaborados de acordo com o modelo societário atual, o que se observa é um direito sobre bens físicos concedidos pela União (poder concedente) a uma distribuidora. A essência econômica da transação ocorrida não é essa, visto que a distribuidora não tem a propriedade ou o controle sobre esses bens, sendo-lhe concedido apenas o direito de usá-los para prestar o serviço público de distribuição de energia elétrica e com isso receber tarifas.

Além disso, surge a questão da definição do ativo a ser considerado como BRR. Porque os ajustes ocorrem? Conforme a Nota Técnica 178/2002-SFF/ANEEL, o ativo imobilizado registrado a custo histórico não pode ser utilizado como base, pois seus valores estão desatualizados em decorrência de diversos fatores ocorridos na economia brasileira que não foram contemplados nas demonstrações societárias; o ajuste feito para cálculo da amortização de capital via quota de reintegração regulatória visa uma taxa de depreciação compatível com a amortização de capital diluída no período contratual.

Se os demonstrativos societários evidenciassem um valor de ativo atualizado, mesmo que por um índice geral de inflação, talvez não se precisasse desse processo de valoração de base de 
ativos regulatória, e se a depreciação ou amortização do ativo evidenciasse a redução do que foi adquirido no contrato, esse ajuste não seria necessário.

Ao voltar à pergunta, esses demonstrativos deveriam evidenciar esses dados? Sim, eles deveriam evidenciar a essência econômica da transação a qual se refletiria nos ajustes realizados. Essa argumentação pode ser reforçada pelo fato de que tanto para a primeira revisão quanto para a segunda, na fixação da nova receita, o regulador utiliza-se da contabilidade regulatória para promover uma avaliação de ativos de uso na prestação do serviço ao custo de reposição para fixar a base de incidência de cálculo da remuneração de capital.

Nesses dois momentos, nota-se a superioridade da base de remuneração em relação ao declínio dos bens do imobilizado registrados a valor de aquisição (custo histórico), conforme quadro abaixo:

Quadro 24 - Comparação ativo imobilizado líquido x base de ativos regulatória

\begin{tabular}{|l|l|c|}
\hline & $1^{\mathrm{a}}$ revisão tarifária & $2^{\mathrm{a}}$ revisão tarifária \\
\hline Ativo Imobilizado Líquido* & 860.000 & 741.000 \\
\hline Base de Ativos Regulatória (BRR) & 1.118 .000 & 1.052 .350 \\
\hline
\end{tabular}

Nota: *Saldo do ativo imobilizado líquido dos anos 2002 e 2007, respectivamente.

Isso decorre da data das revisões ser janeiro de 2003 e janeiro de 2008.

Observa-se que, com isso, são criados dois valores para o ativo imobilizado em serviço, um ajustado para o processo de revisão tarifária (regulatório) e um para fins de controle contábil (societário). Cria-se assim um ativo imobilizado em serviço regulatório que difere do ativo imobilizado do balanço societário.

A esse respeito é importante ressaltar que houve um movimento ${ }^{89}$ da Aneel para que essa avaliação de ativos estivesse refletida no balanço societário como uma reavaliação de ativos. No entanto, não houve êxito, pois quando do início do processo de avaliação de ativos do setor elétrico, a lei 11.638/2007 já se encontrava em tramitação e esta exclui a possibilidade de reavaliação do ativo imobilizado.

Alem disso, cabe ressaltar que os custos que as distribuidoras arcam para promover essa avaliação de ativos regulatória são cobrados na tarifa, ou seja, são pagos pelos consumidores de energia elétrica.

Se o EEF nasce do pagamento da remuneração, entendida como adequada pelo regulador sobre os investimentos e a amortização do capital investido (CAPEX), bem como da cobertura

\footnotetext{
${ }^{89} \mathrm{O}$ movimento citado refere-se a uma consulta realizada pela Aneel à Comissão de Valores Mobiliários - CVM a respeito da avaliação de ativos regulatória estar evidenciada nos demonstrativos financeiros.
} 
dos custos operacionais, via tarifa, e ainda da vontade das partes na pactuação deste equilíbrio, uma maneira de visualizar esse EEF seria por meio de demonstrativos que evidenciassem em alguma medida algum desses itens.

De posse desses demonstrativos elaborados de acordo com o modelo atual, não é possível identificar o que está sendo pago via tarifa. A conjugação dos fatores discutidos resulta em uma não identificação do $\boldsymbol{E} \boldsymbol{E F}$ pelos demonstrativos tradicionais, não sendo passível de verificação se as tarifas estão cobrindo os custos de capital incorridos pelas distribuidoras e deixando confuso o que está sendo pago pelas tarifas como fundo para recomposição dos bens concedidos e amortização de capital.

Diante da dificuldade em se apontar de forma transparente se o EEF previsto no contrato de concessão está sendo alcançado, as entidades do setor vêm agindo na defesa de seus interesses.

Um estudo apresentado pelo Instituto Acende Brasil $^{90}$ (2007), realizado pela consultoria Stern Stewart \& Co., o qual pesquisou 34 distribuidoras de energia elétrica no período 1998 a 2006, afirma que o setor apresentou rentabilidade permanentemente negativa entre 1998 e 2006. O estudo foi realizado com base no EVA (Economic Value Added). A opção pelo EVA justificase pelo fato de o setor elétrico ser intensivo em capital e a metodologia incorporar o custo de oportunidade do capital. Segundo o estudo, a destruição de valor (acumulada no período 19982006) chega a R $\$ 81$ bilhões se considerada a incidência do índice de inflação sobre o valor da perda.

Por outro lado, um estudo apresentado pela ABRACE (2007) ${ }^{91}$, que congrega os grandes consumidores de energia elétrica, feito com as distribuidoras de distribuição ao longo do primeiro ciclo de revisões tarifárias, baseado na comparação entre a remuneração regulatória somada à quota de reintegração e a remuneração real das empresas, os resultados encontrados mostram que as empresas distribuidoras ${ }^{92}$ apresentam remuneração real superior a remuneração regulatória.

Os dois estudos apontam como fonte de dados os demonstrativos financeiros disponibilizados pela Comissão de Valores Mobiliários - CVM e os valores de remuneração fixados pela Aneel.

\footnotetext{
${ }^{90}$ O Instituto Acende Brasil é um Centro de Estudos voltado ao desenvolvimento de ações e projetos para aumentar o grau de Transparência e Sustentabilidade do Setor Elétrico Brasileiro.

${ }^{91}$ Contribuições a Audiência Pública 052/2007, sobre as metodologias de cálculo para o segundo ciclo tarifário.

${ }^{92}$ Empresas: Coelba, Cosern, Bandeirante, Escelsa, Enersul, Celpe, CPFL-Paulista e Piratininga, Light, Cemig, RGE, Eletropaulo, Copel, Aes-sul, Energipe, Celb, Saelpa, Cenf e Cataguazes Leopoldina. Dessas, a única que apresenta remuneração real inferior a regulatória é a Light, distribuidora do Rio de Janeiro.
} 
Diante do exposto surge o questionamento se a contabilidade poderia de alguma forma contribuir para identificação do EEF, uma vez que esta é utilizada para sua definição. Conforme demonstrado adiante, a adoção de algumas normas internacionais de contabilidade contribui para que esse objetivo seja alcançado.

\subsection{SIMULAÇÃO DAS DEMONSTRAÇÕES FINANCEIRAS DE UM CONTRATO DE CONCESSÃO DE ACORDO COM A INTERPRETAÇÃO IFRIC 12}

Um dos aspectos mais relevantes para este trabalho se refere à definição de ativos sujeitos à contabilização. Segundo a IFRIC 12, a infra-estrutura utilizada para a prestação do serviço, dentro do âmbito de aplicação dessa interpretação, não deve ser reconhecida como ativo imobilizado da distribuidora, haja vista que no caso das concessões do setor elétrico o que se adquire por meio do contrato de concessão é o direito de exploração da atividade durante um determinado período de tempo.

O novo modelo proposto pela IFRIC 12 altera substancialmente a visão atual apresentada nos demonstrativos societários e regulatórios, transportando as demonstrações financeiras para a evidenciação dos direitos decorrentes do fato econômico, ou seja, o foco passa a ser a essência econômica da transação.

De acordo com a IFRIC 12, para a correta caracterização do fato econômico é necessário identificar a natureza do ativo, se financeiro ou intangível. Para isso, é importante considerar que a aquisição do direito de exploração do serviço não gera, por si só, a entrada de recursos financeiros para a entidade privada, visto que essa receita está subordinada ao efetivo uso do serviço.

Há, portanto, riscos associados principalmente à demanda dos usuários e ao desempenho da empresa que devem ser considerados na classificação do evento, considerando que o direito incondicional de receber só ocorre com a distribuição de energia elétrica.

Observa-se, assim, que o ativo não garante fluxos de caixas futuros pré-definidos, apenas o direito de explorar o ativo do estado e, por meio dele, obter remuneração adequada e suficiente para a manutenção do equilíbrio econômico-financeiro previsto no contrato de concessão. Tal situação, segundo a IFRIC 12, leva ao tratamento contábil do direito como sendo um ativo intangível.

Reforçando esse entendimento, pode-se considerar ainda que o concessionário abre mão de benefícios que possui (recursos financeiros) para ter o direito de receber remunerações dos 
usuários do serviço público objeto da concessão, e o ativo intangível representa de forma mais clara o custo desse esforço.

A adoção desse conceito altera de forma significativa a maneira de evidenciação do desempenho econômico evidenciado nas demonstrações financeiras das empresas do setor elétrico brasileiro, considerando que implica a exclusão total dos ativos físicos hoje registrados, de onde é extraída a base de cálculo da remuneração do investidor, e a sua substituição por direitos referentes a ativos intangíveis relativos ao direito de exploração da prestação do serviço de energia elétrica.

No que se refere ao valor de registro contábil, segundo a IFRIC 12, o valor de um ativo intangível é avaliado pelo valor justo (fair value) a não ser que não tenha natureza comercial ou quando o seu valor justo não puder ser mensurado corretamente.

Nesse sentido, cita-se a conceituação do que vem a ser valor justo, considerando que é por esse valor que o ativo intangível deve ser mensurado. De acordo com Martins (2006, p. 120), o valor justo de mercado (fair market value) representa "o montante que poderia ser recebido com a venda de um ativo quando existem compradores e vendedores interessados $e$ financeiramente capazes de concretizar a transação e inexistem circunstâncias anormais tais como liquidação, desabastecimento e emergência”.

Considerando a discussão apresentada referente à mensuração do ativo a fair value e utilizando a hierarquia apresentada pelo SFAS 157, e dado que o valor de mercado depende em parte das expectativas sobre restrições regulatórias, um enfoque de transação de mercado tende a ser circular, e se os investidores superavaliarem a transação e pagarem "muito" pelo ativo, obrigando os consumidores a pagarem preços baseados no valor de aquisição, isto resultaria em uma transferência líquida de riqueza dos consumidores correntes e futuros para os donos anteriores dos ativos.

Sendo assim, este trabalho adotará o Custo de Reposição como melhor estimativa de fair value.

Feitas essas considerações, adota-se na simulação das demonstrações financeiras elaboradas de acordo com o modelo baseado na IFRIC 12 o valor do ativo intangível, como sendo o mesmo valor fixado pela BRR, à custo de reposição. Os demais parâmetros utilizados são os mesmos aplicados nos exercícios anteriores realizados de acordo com o modelo societário atual. Considera-se o valor do intangível inicial em 2003, sem outras avaliações no decorrer do período analisado.

Para a simulação em questão, tomam-se os eventos econômicos a partir da primeira revisão tarifária, no ano de 2003, considerando que foi neste ano a primeira avaliação de ativos a 
custo de reposição, aqui considerado como o valor de mensuração do intangível, fair value, e considerando também que durante o período de 1998 a 2002 não aconteceram fatos que alterassem o equilíbrio econômico-financeiro pactuado no contrato de concessão, conforme discutido no item 3.3.4 deste trabalho e observados os parâmetros iniciais contidos no item 4.1. 
Quadro 25 - Demonstrativos financeiros de acordo com a interpretação IFRIC 12

\begin{tabular}{|c|c|c|c|c|c|c|c|c|c|c|c|c|}
\hline & \multicolumn{6}{|c|}{$1^{0}$ Ciclo Revisório } & \multicolumn{5}{|c|}{$2^{0}$ Ciclo Revisório } & \multirow{2}{*}{$\begin{array}{c}\text { Fim } \\
2018 \\
\end{array}$} \\
\hline & Inicio & 2003 & 2004 & 2005 & 2006 & 2007 & 2008 & 2009 & 2010 & 2011 & 2012* & \\
\hline Caixa & & 546.597 & 622.794 & 798.990 & 975.187 & 1.151 .384 & 1.303 .449 & 1.305 .513 & 1.457 .578 & 1.609 .642 & 1.761 .707 & 2.674 .094 \\
\hline Ativo intangível & 1.318 .000 & 1.318 .000 & 1.418 .000 & 1.418 .000 & 1.418 .000 & 1.418 .000 & 1.418 .000 & 1.568 .000 & 1.568 .000 & 1.568 .000 & 1.568 .000 & 1.568 .000 \\
\hline Novos investimentos & & & 100.000 & & & & & 150.000 & & & & \\
\hline Amortização acumulada & $(200.000)$ & $(269.875)$ & $(346.417)$ & $(422.958)$ & (499.500) & $(576.042)$ & $(652.583)$ & $(744.125)$ & $(835.667)$ & $(927.208)$ & $(1.018 .750)$ & $(1.568 .000)$ \\
\hline Ativo Intangível líquido & 1.118 .000 & 1.048 .125 & 1.071 .583 & 995.042 & 918.500 & 841.958 & 765.417 & 823.875 & 732.333 & 640.792 & 549.250 & -0 \\
\hline TOTAL DO ATIVO & & 1.594.722 & 1.694.377 & 1.794.032 & 1.893.687 & 1.993 .342 & 2.068.865 & 2.129.388 & 2.189 .911 & 2.250 .434 & 2.310.957 & 2.674 .094 \\
\hline \multicolumn{13}{|l|}{ Passivo } \\
\hline Patrimônio Líquido & & 1.594 .722 & 1.694 .377 & 1.794 .032 & 1.893 .687 & 1.993 .342 & 2.068 .865 & 2.129 .388 & 2.189 .911 & 2.250 .434 & 2.310 .957 & 2.674 .094 \\
\hline Cap. Social & & 1.318 .000 & 1.318 .000 & 1.318 .000 & 1.318 .000 & 1.318 .000 & 1.318 .000 & 1.318 .000 & 1.318 .000 & 1.318 .000 & 1.318 .000 & 1.318 .000 \\
\hline Resultado do exercício & & 106.322 & 99.655 & 99.655 & 99.655 & 99.655 & 75.523 & 60.523 & 60.523 & 60.523 & 60.523 & 60.523 \\
\hline Lucros/Prejuízos acumulados & & 170.400 & 276.722 & 376.377 & 476.032 & 575.687 & 675.342 & 750.865 & 811.388 & 871.911 & 932.434 & 1.295 .571 \\
\hline TOTAL DO PASSIVO & & 1.594.722 & 1.694.377 & 1.794 .032 & 1.893.687 & 1.993 .342 & 2.068.865 & 2.129.388 & 2.189 .911 & 2.250 .434 & 2.310 .957 & 2.674 .094 \\
\hline \multicolumn{13}{|l|}{ DRE } \\
\hline Receita tarifária & & 196.197 & 196.197 & 196.197 & 196.197 & 196.197 & 182.065 & 182.065 & 182.065 & 182.065 & 182.065 & 182.065 \\
\hline Despesa operacional & & $(20.000)$ & $(20.000)$ & $(20.000)$ & $(20.000)$ & $(20.000)$ & $(30.000)$ & $(30.000)$ & $(30.000)$ & $(30.000)$ & $(30.000)$ & $(30.000)$ \\
\hline Despesa amortização & & $(69.875)$ & $(76.542)$ & $(76.542)$ & $(76.542)$ & $(76.542)$ & $(76.542)$ & $(91.542)$ & $(91.542)$ & $(91.542)$ & $(91.542)$ & $(91.542)$ \\
\hline Resultado do exercício & & 106.322 & 99.655 & 99.655 & 99.655 & 99.655 & 75.523 & 60.523 & 60.523 & 60.523 & 60.523 & 60.523 \\
\hline \multicolumn{13}{|l|}{ FLUXO DE CAIXA } \\
\hline Caixa inicial & & 370.400 & 546.597 & 622.794 & 798.990 & 975.187 & 1.151 .384 & 1.303 .449 & 1.305 .513 & 1.457 .578 & 1.609 .642 & 2.522 .030 \\
\hline Recebimento de tarifas & & 196.197 & 196.197 & 196.197 & 196.197 & 196.197 & 182.065 & 182.065 & 182.065 & 182.065 & 182.065 & 182.065 \\
\hline Realização de Investimentos & & & $(100.000)$ & - & - & - & - & (150.000) & - & - & - & - \\
\hline Despesa operacional & & $(20.000)$ & $(20.000)$ & $(20.000)$ & $(20.000)$ & $(20.000)$ & $(30.000)$ & $(30.000)$ & $(30.000)$ & $(30.000)$ & $(30.000)$ & $(30.000)$ \\
\hline Caixa final & & 546.597 & 622.794 & 798.990 & 975.187 & 1.151.384 & 1.303 .449 & 1.305 .513 & 1.457.578 & 1.609.642 & 1.761 .707 & 2.674.094 \\
\hline
\end{tabular}

Nota: - Principais pontos analisados: ativo intangível líquido e despesa de amortização; *a partir do ano de 2013 todas as variáveis são replicadas ocorrendo apenas sua evolução. 
Na simulação acima, parte-se do pressuposto que o valor do direito adquirido no início do contrato possui valor de avaliação idêntico ao valor fixado como BRR líquida. A coluna início visa identificar a partida para as demonstrações simuladas. Diante da comparação dos modelos, questiona-se: qual deles permite a melhor identificação do equilíbrio econômicofinanceiro fixado nas revisões tarifárias?

\subsubsection{Evidenciação do Ativo, sua evolução e investimentos realizados}

Na celebração do contrato de concessão, o objeto do negócio é o direito de exploração do serviço de distribuição de energia elétrica para uma determinada região, durante um determinado período de tempo, usando a infra-estrutura do estado e tendo como contrapartida o recebimento de receitas tarifárias. Portanto, o fato econômico que se observa é a aquisição de um direito.

Conforme apresentado no Capítulo 3, a distribuidora, para alienar os bens vinculados à prestação de serviço público de energia elétrica, precisa de autorização da Aneel. Assim, embora a distribuidora esteja explorando a prestação do serviço, o concedente continua a ter o controle da infra-estrutura, pois é ele quem determina as tarifas a serem cobradas (preço) e a desvinculação de bens, bem como detém o interesse residual sobre esses mesmos bens.

Diante dessa argumentação, conclui-se que a demonstração contábil contida no modelo tradicional não evidencia adequadamente a "essência da transação" ocorrida na celebração dos contratos de concessão do setor de energia elétrica, visto que os ativos registrados não expressam os bens e direitos de cada entidade.

$\mathrm{Na}$ contabilização, seguindo as orientações da IFRIC 12, a amortização do ativo intangível ocorreria no prazo do contrato de concessão, ou seja, em 20 anos, isso equivale a uma taxa média anual de $5 \%$ ao ano.

Nesse modelo não há valor residual. Com o fim do contrato exaure-se com ele o direito de exploração e isso está evidenciado na demonstração da amortização acumulada, conforme abaixo: 
Quadro 26 - Extrato do balanço da concessão - modelo IFRIC12 - ativo intangível

\begin{tabular}{|l|c|c|c|c|c|c|}
\hline & \multicolumn{7}{|c|}{$\mathbf{1}^{\mathbf{0}}$ Ciclo Revisório } \\
\hline & Inicio & $\mathbf{2 0 0 3}$ & $\mathbf{2 0 0 4}$ & $\mathbf{2 0 0 5}$ & $\mathbf{2 0 0 6}$ & $\mathbf{2 0 0 7}$ \\
\hline Ativo Intangível & 1.318 .000 & 1.318 .000 & 1.418 .000 & 1.418 .000 & 1.418 .000 & 1.418 .000 \\
\hline Amortização Acumulada & $(200.000)$ & $(269.875)$ & $(346.417)$ & $(422.958)$ & $(499.500)$ & $(576.042)$ \\
\hline Ativo Intangível Líquido & 1.118 .000 & 1.048 .125 & 1.071 .583 & 995.042 & 918.500 & 841.958 \\
\hline
\end{tabular}

Continuação do Quadro 26 - Extrato do balanço da concessão - modelo IFRIC12 - ativo intangível

\begin{tabular}{|l|c|c|c|c|c|c|}
\hline & \multicolumn{5}{|c|}{$\mathbf{2}^{\mathbf{0}}$ Ciclo Revisório } & Fim \\
\hline & $\mathbf{2 0 0 8}$ & $\mathbf{2 0 0 9}$ & $\mathbf{2 0 1 0}$ & $\mathbf{2 0 1 1}$ & $\mathbf{2 0 1 2}$ & $\mathbf{2 0 1 8}$ \\
\hline Ativo Intangível & 1.418 .000 & 1.568 .000 & 1.568 .000 & 1.568 .000 & 1.568 .000 & 1.568 .000 \\
\hline Amortização Acumulada & $(652.583)$ & $(744.125)$ & $(835.667)$ & $(927.208)$ & $(1.018 .750)$ & $(1.568 .000)$ \\
\hline Ativo Intangível Líquido & 765.417 & 823.875 & 732.333 & 640.792 & 549.250 & 0 \\
\hline
\end{tabular}

Observa-se que, ao final do contrato, pelo modelo IFRIC, a posição financeira deverá estar liquidada, pois as obrigações contratuais foram extintas de forma que os acionistas tiveram o retorno do capital pelo investimento realizado e isto está evidenciado no direito expresso como ativo intangível nulo.

Já no caso do modelo societário tradicional, como a evolução do direito está representada pelo ativo imobilizado e a este incide depreciação de acordo com sua vida útil, sempre que o período do contrato não for igual ao período de vida útil do ativo, no fim do contrato, haverá valores residuais.

Quanto aos investimentos realizado durante o período do contrato em 2004 e 2009, pela interpretação IFRIC 12, cabe ao concessionário agregar ao ativo intangível o valor dos investimentos efetivamente realizados na aquisição ou modernização dos ativos operacionais, visto que tal medida constitui-se obrigação prevista quando da aquisição inicial do direito de exploração do serviço público e, principalmente, que os bens adquiridos possuem a mesma natureza dos componentes da infra-estrutura inicial no que se refere à propriedade de direito ao uso.

De acordo com a IFRIC 12, dos contratos surgem obrigações que o operador tem que cumprir: manter a infra-estrutura em um determinado nível de manutenção e restaurar a infraestrutura em uma determinada condição antes de entregá-la ao concedente no final do contrato de serviço.

Estas obrigações contratuais para manter ou restaurar infra-estrutura, com exceção de qualquer elemento upgrade, devem ser contabilizadas em conformidade com o IAS 37 Provisões, Passivos Contingentes e Ativos Contingentes, ou seja, na melhor estimativa da 
despesa que seria necessária para resolver a obrigação presente na data do balanço. É ressaltado que nenhuma infra-estrutura, construída ou não, pode ser reconhecida como ativo permanente da distribuidora (parágrafo 11, IFRIC 12).

Esta leitura leva ao entendimento de que se uma substituição, por exemplo, não for contratual, e for de vontade própria da distribuidora, por algum motivo, essa não é provisionada. No exercício representado acima, considera-se que nos anos de 2004 e 2009 foram realizados investimentos não provisionados. A contabilização tem caráter similar ao do investimento inicial, com o registro do valor investido no ativo intangível e amortização até o final do prazo contratual.

Essa configuração identifica melhor o direito adquirido através do contrato e sua evolução com a agregação dos investimentos realizados, pois este se refere ao direito de uso da infra-estrutura e não à posse dos ativos propriamente ditos. Esse tratamento está de acordo com o parágrafo 11 da IFRIC 12, mencionado anteriormente.

\subsubsection{Visualização do Equilíbrio Econômico-Financeiro - EEF após a revisão tarifária}

$\mathrm{Na}$ análise da identificação do EEF, o evento a ser analisado é o da formação da receita tarifária como instrumento de manutenção do equilíbrio econômico-financeiro, pois possibilita a adequação dos valores cobrados dos usuários de forma que se obtenha a remuneração e amortização do capital investido, além da cobertura dos custos de operação.

Dessa forma, uma maneira de identificar as variáveis remuneração e amortização de capital via Demonstração do Resultado do Exercício - DRE, deve ser feita considerando as premissas regulatórias apresentadas abaixo:

a) no início do contrato, concedente e operador pactuam que as tarifas vigentes conferem equilíbrio econômico-financeiro ao contrato de forma que possibilite ao operador obter remuneração sobre o capital investido e o seu retorno no prazo do contrato de concessão;

b) a existência desse equilíbrio é apurada periodicamente nas revisões tarifárias que ocorrem a cada 4 ou 5 anos, de acordo com o contrato de concessão. Nesse ponto é que se insere a aplicação das normas internacionais de contabilidade com o objetivo de proporcionar uma visão mais clara do desempenho econômico da entidade por meio da análise de suas demonstrações financeiras;

c) nas revisões tarifárias, a fixação da receita de equilíbrio decorre principalmente da aplicação de uma taxa de custo de capital (WACC regulatório) sobre uma base 
formada por ativos avaliados a custo de reposição, adicionada de uma quota de reintegração regulatória e dos custos operacionais fixados;

d) o papel do processo de revisão tarifária é estabelecer os fluxos de CAPEX e OPEX em relação à arrecadação tarifária e para isso utiliza-se a contabilidade regulatória.

Por outro lado, ao considerar a aplicação das interpretações internacionais na sistemática da receita de equilíbrio, contribui-se para uma melhor identificação do equilíbrio econômico-financeiro do contrato, permitindo correções pela identificação dos desvios como resultado da interpretação das demonstrações contábeis.

Vejamos o exercício de um fluxo de caixa com base nas informações extraídas da DRE.

Quadro 27 - Fluxo de caixa 2003-2007

\begin{tabular}{|c|c|c|c|c|c|c|}
\hline & \multicolumn{6}{|c|}{$1^{0}$ CICLO REVISÓRIO } \\
\hline FLUXO DE CAIXA & Inicio & 2003 & 2004 & 2005 & 2006 & 2007 \\
\hline 1) Receita Tarifária & & 196.197 & 196.197 & 196.197 & 196.197 & 196.197 \\
\hline 2) Despesas Operacionais Totais & & $(89.875)$ & $(96.542)$ & $(96.542)$ & $(96.542)$ & $(96.542)$ \\
\hline 2.1)Despesas Operacionais & & $(20.000)$ & $(20.000)$ & $(20.000)$ & $(20.000)$ & $(20.000)$ \\
\hline 2.2)Depreciação dos Ativos & & $(69.875)$ & $(76.542)$ & $(76.542)$ & $(76.542)$ & $(76.542)$ \\
\hline 3) Investimentos & & & $(100.000)$ & & & \\
\hline$=$ Resultado & & 106.322 & (345) & 99.655 & 99.655 & 99.655 \\
\hline Investimentos (BRR) & $(1.118 .000)$ & & & & & 841.958 \\
\hline Amortização de ativos & & 69.875 & 76.542 & 76.542 & 76.542 & 76.542 \\
\hline Fluxo de caixa livre* & $(1.118 .000)$ & 176.197 & 76.197 & 176.197 & 176.197 & 1.018.155 \\
\hline Rentabilidade Anual & & $10,14 \%$ & $-0,03 \%$ & $10,02 \%$ & $10,85 \%$ & $11,84 \%$ \\
\hline TIR Primeiro ciclo revisório & $9,75 \%$ & & & & & \\
\hline
\end{tabular}


Quadro 28 - Fluxo de caixa 2008-2012

\begin{tabular}{|c|c|c|c|c|c|c|}
\hline \multirow[b]{2}{*}{ FLUXO DE CAIXA } & \multicolumn{6}{|c|}{$2^{\circ}$ CICLO REVISÓRIO } \\
\hline & Inicio & 2008 & 2009 & 2010 & 2011 & 2012 \\
\hline 1) Receita Tarifária & & 182.065 & 182.065 & 182.065 & 182.065 & 182.065 \\
\hline 2) Despesas Operacionais Totais & & $(106.542)$ & $(121.542)$ & $(121.542)$ & $(121.542)$ & $(121.542)$ \\
\hline 2.1) Despesas Operacionais & & $(30.000)$ & $(30.000)$ & $(30.000)$ & $(30.000)$ & $(30.000)$ \\
\hline 2.2) Depreciação dos Ativos & & $(76.542)$ & $(91.542)$ & $(91.542)$ & $(91.542)$ & $(91.542)$ \\
\hline 3) Investimentos & & & $(150.000)$ & & & \\
\hline$=$ Resultado & & 75.523 & $(89.477)$ & 60.523 & 60.523 & 60.523 \\
\hline Investimentos (BRR) & $(1.052 .350)$ & & & & & 789.263 \\
\hline Amortização de ativos & & 76.542 & 91.542 & 91.542 & 91.542 & 91.542 \\
\hline Fluxo de caixa livre* & $(1.052 .350)$ & 152.065 & 2.065 & 152.065 & 152.065 & 941.327 \\
\hline Rentabilidade Anual & & $7,55 \%$ & $-9,45 \%$ & $6,77 \%$ & $7,19 \%$ & $7,67 \%$ \\
\hline TIR Segundo ciclo revisório & $7,07 \%$ & & & & & \\
\hline
\end{tabular}

Pelos fluxos de caixa apurados é possível observar uma TIR resultante nos períodos tarifários de 9,69\% no primeiro ciclo e de 7,07\% no segundo ciclo. Neste modelo, o WACC fixado pelo regulador se aproxima mais da TIR encontrada pelos fluxos de caixa, 11,26\% e $9,95 \%$, primeiro e segundo ciclo, respectivamente. Isso ocorre porque nesse modelo estão representados os investimentos iniciais pelo valor da BRR e sua amortização, ou seja, as demonstrações contábeis permitiriam a simulação de um fluxo de caixa com os valores mais aderentes ou até mesmo iguais aos valores utilizados pelo regulador.

Nesse modelo, observa-se também o impacto da realização dos investimentos durante o período tarifário na apuração da TIR, visto que se não houvesse investimento, esta seria de $13,31 \%$, conforme abaixo. 
Quadro 29 - Fluxo de caixa da concessão 2003-2008 - sem investimentos adicionais

\begin{tabular}{|c|c|c|c|c|c|c|}
\hline & \multicolumn{6}{|c|}{1 CICLO REVISÓRIO } \\
\hline FLUXO DE CAIXA & Inicio & 2003 & 2004 & 2005 & 2006 & 2007 \\
\hline 1)Receita Tarifária & & 196.197 & 196.197 & 196.197 & 196.197 & 196.197 \\
\hline 2)Despesas Operacionais Totais & & $(89.875)$ & $(89.875)$ & $(89.875)$ & $(89.875)$ & $(89.875)$ \\
\hline 2.1)Despesas Operacionais & & $(20.000)$ & $(20.000)$ & $(20.000)$ & $(20.000)$ & $(20.000)$ \\
\hline 2.2)Depreciação dos Ativos & & $(69.875)$ & $(69.875)$ & $(69.875)$ & $(69.875)$ & $(69.875)$ \\
\hline 3)Investimentos & & & - & & & \\
\hline$=$ Resultado & & 106.322 & 106.322 & 106.322 & 106.322 & 106.322 \\
\hline Investimentos (BRR) & $(1.118 .000)$ & 1.062 .100 & 1.006 .200 & 950.300 & 894.400 & 841.958 \\
\hline Amortização de ativos & & 69.875 & 69.875 & 69.875 & 69.875 & 69.875 \\
\hline Fluxo de caixa livre & $(1.118 .000)$ & 176.197 & 176.197 & 176.197 & 176.197 & 1.018 .155 \\
\hline Rentabilidade Anual & & $10,01 \%$ & $10,57 \%$ & $11,19 \%$ & $11,89 \%$ & $12,63 \%$ \\
\hline TIR Primeiro ciclo revisório & $11,86 \%$ & & & & & \\
\hline
\end{tabular}

A TIR apurada pelo fluxo de caixa sem realização de investimentos $(11,86 \%)$ apresenta um aumento em torno de três pontos percentuais em relação ao fluxo com investimento $(9,75 \%)$. Para o segundo ciclo, sem considerar os investimentos, a TIR apurada é de $10,39 \%$, apresentando aumento de quatro pontos percentuais em relação ao fluxo com investimentos $(7,07 \%)$.

A análise da TIR com investimento e sem investimento é a mesma da análise do modelo societário atual. A realização de investimentos reduz a TIR do período, em compensação, sendo esse investimento entendido como prudente, passa a compor a base de remuneração aumentando a receita tarifária do próximo ciclo.

Feitas essas considerações sobre o efeito da realização de investimentos, apresenta-se a seguir o indicador ROI, em sua formulação analítica, considerando a simulação em estudo.

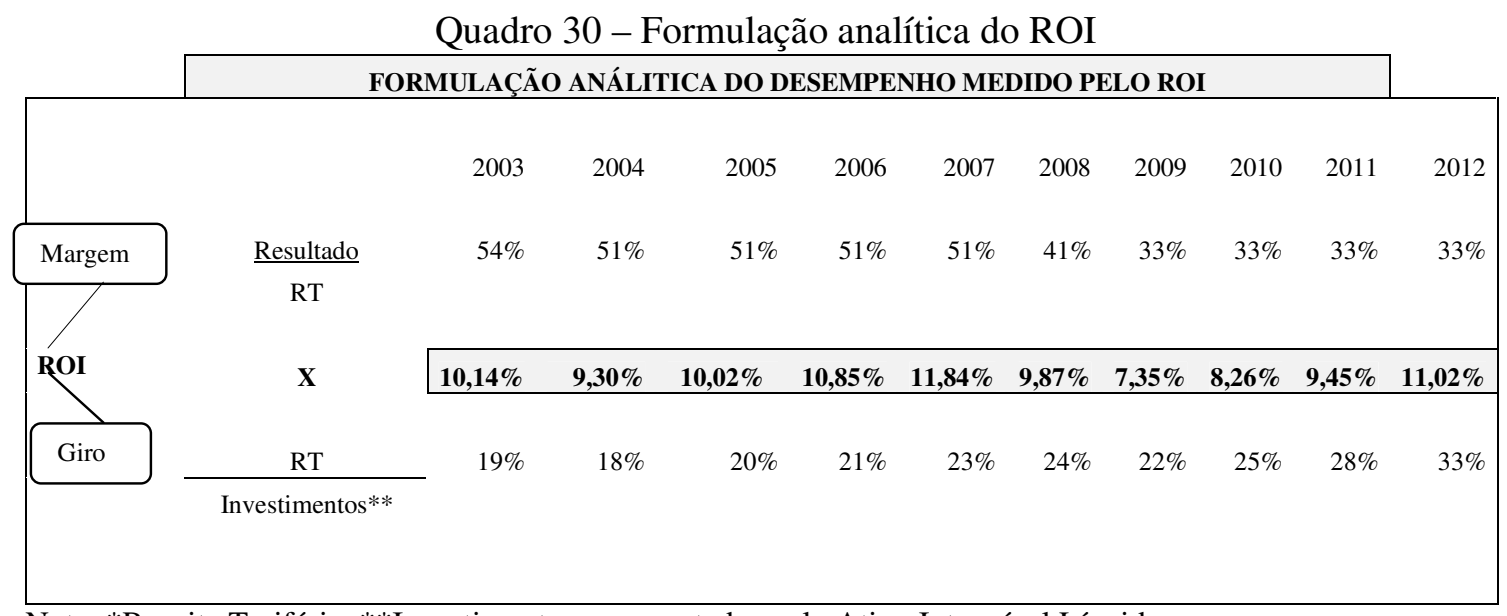

Nota: *Receita Tarifária; **Investimentos representados pelo Ativo Intangível Líquido. 
A análise desse indicador aponta que a distribuidora tem um retorno sobre o investimento de $10,14 \%$ em 2003, no momento da fixação da receita de equilíbrio, atravessando o primeiro ciclo com esse indicador variando entre 10,02\%, em 2005, e alcançando 11,84\% no último ano do ciclo, em 2007.

Para o período tarifário seguinte (2008-2012) esse indicador inicia em patamares de $9,87 \%$, variando entre $8,26 \%$ e $11,02 \%$. Os reflexos dos investimentos realizados nos períodos podem ser vistos com a redução do indicador nos anos de 2004 e 2009.

A comparação desse indicador com a TIR, entre as simulações realizadas, apresenta as seguintes diferenças.

Tabela 3 - Tabela comparativa dos indicadores apurados pelo modelo societário atual e pelo modelo IFRIC $12-1^{\circ}$ ciclo

\begin{tabular}{|l|c|c|c|c|c|c|}
\hline \multicolumn{7}{|c|}{ TABELA COMPARATIVA DOS INDICADORES USADOS - 1 } \\
\hline & TIR & \multicolumn{4}{c|}{ ROI } & \multicolumn{2}{c|}{} \\
\hline & $\mathbf{1}^{\mathbf{0}}$ CICLO & $\mathbf{2 0 0 3}$ & $\mathbf{2 0 0 4}$ & $\mathbf{2 0 0 5}$ & $\mathbf{2 0 0 6}$ & $\mathbf{2 0 0 7}$ \\
\hline Modelo Atual & $15,83 \%$ & $17,11 \%$ & $12,57 \%$ & $16,83 \%$ & $17,66 \%$ & $18,58 \%$ \\
\hline Modelo IFRIC & $9,75 \%$ & $10,14 \%$ & $9,30 \%$ & $10,02 \%$ & $10,85 \%$ & $11,84 \%$ \\
\hline Índice Rent. Regulatória & $\mathbf{1 7 , 5 5 \%}$ & \multicolumn{5}{|l}{} \\
\hline
\end{tabular}

Tabela 4 - Tabela comparativa dos indicadores apurados pelo modelo societário atual e pelo modelo IFRIC $12-2^{\circ}$ ciclo

\begin{tabular}{|c|c|c|c|c|c|c|}
\hline \multicolumn{7}{|c|}{ TABELA COMPARATIVA DOS INDICADORES USADOS $2^{\circ}$ CICLO } \\
\hline & TIR & \multicolumn{5}{|c|}{ ROI } \\
\hline & $2^{\circ}$ CICLO & 2008 & 2009 & 2010 & 2011 & 2012 \\
\hline Modelo Atual & $14,69 \%$ & $16,17 \%$ & $13,39 \%$ & $14,16 \%$ & $15,02 \%$ & $15,99 \%$ \\
\hline Modelo IFRIC & $7,07 \%$ & $9,87 \%$ & $7,35 \%$ & $8,26 \%$ & $9,45 \%$ & $11,02 \%$ \\
\hline Índice Rent. Regulatória & $17,30 \%$ & & & & & \\
\hline
\end{tabular}

Ressalta-se que o IR regulatório - Índice de Rentabilidade Regulatório - é formado pela seguinte equação: $\mathbf{I R}_{\text {reg }}=\mathbf{R E} / \mathbf{B R R}$. Um aspecto importante desse índice é sua característica de tratar-se de um objetivo fixado no processo de revisão tarifária e que deve ser buscado durante o ciclo tarifário. Além disso, por convenção das partes, pressupõe-se que este representa o equilíbrio econômico-financeiro a ser mantido durante esse período.

Nesse modelo, um indicador de rentabilidade comparável com o índice de rentabilidade regulatória é o ROI - Retorno sobre Investimentos, visto que possui formulação similar à equação acima indicada. Nota-se que seus componentes são comparáveis, conforme demonstrado a seguir. 
Tabela 5 - Tabela comparativa de indicadores

\begin{tabular}{|c|ccc|}
\hline \multicolumn{4}{|c|}{ INDICADORES } \\
\hline IR $_{\text {reg }}$ & \multicolumn{3}{|c|}{ ROI } \\
\hline & MARGEM & X & GIRO \\
RE/BRR & (Resultado/RE) & $X$ & (RE/Investimento) \\
\hline
\end{tabular}

Observa-se que, o IR regulatório apresenta uma receita esperada e o ROI contempla a receita efetivamente obtida e expressa nas demonstrações financeiras; e no que se refere à base da equação, o ativo intangível (modelo IFRIC) avaliado a fair value ao ser mensurado a custo de reposição, encontrando assim correspondência com a base de remuneração regulatória.

O ROI do modelo atual tem como base de cálculo o Ativo Imobilizado líquido (custo histórico) que não corresponde ao efetivo investimento a valor justo do ativo adquirido no contrato de concessão. Portanto, o indicador obtido não representa o efetivo retorno sobre o investimento realizado.

Por outro lado, nas demonstrações elaboradas de acordo com a interpretação IFRIC 12, ao melhor demonstrar o ativo adquirido e contemplar a sua mensuração a fair value, o indicador aproxima-se mais do retorno sobre o investimento, permitindo sua comparação com o índice de rentabilidade fixado na revisão tarifária como indicador do equilíbrio do contrato de concessão.

Percebe-se que o indicador de rentabilidade é prospectivo, uma vez que a receita de equilíbrio fixada na revisão tarifária tem a característica de ser um objetivo a ser atingido, e que para a apuração do índice de rentabilidade regulatória utiliza-se o valor da Base de Remuneração Regulatória à custo de reposição.

Então a rentabilidade regulatória é comparável com o ROI obtido nos demonstrativos IFRIC 12, haja vista a correspondência entre BRR e ativo intangível.

A esse respeito cabem algumas considerações. Foram apresentados no início deste capítulo os ajustes realizados nos valores do ativo imobilizado do modelo societário atual para fixação da base de remuneração regulatória e o ajuste para recompor e amortizar investimentos realizados.

Ao discutir os ajustes (avaliação a custo de reposição) realizados no ativo imobilizado para apuração da base de remuneração, observa-se que este é feito com o objetivo de encontrar um valor de mensuração considerado adequado pelo regulador. A "adoção desse método propicia a existência de um ambiente de mercado, condição essencial para a entrada 
de novos investidores, definição de tarifas justas e prestação do serviço com qualidade" e ainda, a "base do ativo deve refletir o valor de mercado do negócio regulado em qualquer ponto no tempo" (NOTA TÉCNICA 178/2002-SFF/ANEEL).

Assim, surge outro questionamento: seriam necessários esses ajustes para a formação da receita de equilíbrio no modelo elaborado de acordo com a IFRIC 12, sendo que para este modelo o ativo intangível é mensurado a fair value (valor justo)?

A reflexão que se pretende levantar sobre os ajustes realizados e o valor justo é que se esses ativos fossem avaliados por um algum valor mais atualizado que o custo histórico vigente, isso possibilitaria a exclusão da necessidade do processo de avaliação de ativos para fixação de base de remuneração regulatória, podendo a base de remuneração ser fixada com base no valor do ativo intangível. Dessa forma, pelos demonstrativos financeiros seria possível identificar um indicador de equilíbrio econômico-financeiro.

Esse argumento é reforçado por três eventos: i) a ocorrência em 2007 de uma tentativa no sentido de tomar como base de remuneração de ativos incrementais (realizados durante o ciclo tarifário) o valor do ativo imobilizado corrigido a índices de inflação específicos (Nota técnica 350/2007-SFF/ANEEL); ii) durante os ciclos, quando a avaliação de ativos a custos de reposição promovida pela distribuidora não é validada pela Aneel, adota-se como base de remuneração o valor do ativo imobilizado a custo histórico corrigido; e iii) o regulador apresenta em algumas notas a dificuldade desse processo de avaliação de ativos regulatórios à custo de reposição.

Para reforçar os argumentos apresentados, na continuidade desse raciocínio apresentase abaixo a relação entre a receita tarifária e o ativo imobilizado representado no modelo societário atual (custo histórico, com valor de 2002, base de cálculo para BRR) e o valor fixado como Base de Remuneração Regulatória - BRR (custo de reposição). Sendo assim, representa-se:

$$
\begin{aligned}
& \mathrm{R}_{1}=\text { Receita Tarifária/Ativo Imobilizado líquido } \\
& \mathrm{R}_{2}=\text { Receita Tarifária/BRR }
\end{aligned}
$$

Comparando $\mathrm{R}_{1}$ com $\mathrm{R}_{2}$ têm-se: 
Tabela 6 - Tabela comparativa entre $\mathrm{R}_{1}$ e $\mathrm{R}_{2}$

\begin{tabular}{|c|c|}
\hline & 2003 \\
\hline $\mathbf{R} 1=$ & $23 \%$ \\
\hline $\mathbf{R} 2=$ & $18 \%$ \\
\hline $\mathbf{R} 1>\mathbf{R} 2$ & $5 \%$ \\
\hline $\mathrm{RI}=\mathrm{R} 2$ & incremento $30 \%$ \\
\hline
\end{tabular}

O R2 apurado em 2003 (18\%), na revisão tarifária periódica, representa o quanto deve ser a proporção Receita Tarifária x Base de Remuneração Regulatória - BRR, pois contempla o momento da fixação da receita de equilíbrio.

O R1 apurado em 2003 (23\%) apresenta a proporção calculada com base no ativo imobilizado líquido (custo histórico) e apresenta uma diferença a menor de cinco pontos percentuais em relação ao R2 fixado pelo regulador.

Para que a relação inicial fixada pelo regulador (R2) seja evidenciada via demonstrativos financeiros, o ativo imobilizado deveria ter valor igual ao da BRR, ou seja, apresentar o valor de mensuração com um incremento de $30 \%$.

Feitas as análises de identificação de um indicador de equilíbrio via demonstrações contábeis, retoma-se a discussão da questão do EEF, que sob o ponto de vista da distribuidora é a determinação se o investimento realizado é reconhecido e amortizado no prazo da concessão e se esse investimento está sendo remunerado pelo uso de capital.

Como o papel da revisão tarifária é balancear o fluxo dos CAPEX e OPEX durante a vigência do contrato, fixando a receita a ser arrecadada na tarifa, para vislumbrar o equilíbrio econômico-financeiro do contrato falta enxergar o OPEX permitido ante o OPEX realizado. Como o OPEX é fixado com base em uma empresa modelo, com base na definição dos custos que incorreria numa empresa eficiente para gerir a atividade de distribuição de energia elétrica, o que o operador incorre a mais ou a menos desse valor fixado é geração ou destruição de valor para o negócio.

A mesma reflexão pode ser feita ao outro ajuste realizado pelo regulador na receita de equilíbrio referente à quota de reintegração. Conforme tratado no item 3.3.4.2.3 - Quota de Reintegração Regulatória, no capítulo 3 e sua formação no item 4.2.1.2, deste capítulo, esta tem a finalidade de recompor os bens e amortizar o capital investido. Seu cálculo é realizado considerando uma taxa média de depreciação regulatória, que não coincide com as taxas apresentadas pelas demonstrações financeiras societárias. 
Se o modelo elaborado de acordo com a IFRIC 12 permite identificar a amortização do ativo, no caso do direito de uso, durante a vida do contrato, conclui-se assim que a sua amortização estaria evidenciada pelas demonstrações financeiras na medida em que explicita a amortização do ativo adquirido no contrato.

Replica-se abaixo um extrato do fluxo de caixa com a amortização do capital investido via tarifa, do primeiro período tarifário.

Quadro 31 - Extrato do balanço da concessão - modelo IFRIC12 - ativo intangível

\begin{tabular}{|l|c|r|r|r|r|r|}
\hline & \multicolumn{7}{|c|}{$\mathbf{1}^{\mathbf{0}}$ Ciclo Revisório } \\
\hline & Inicio & $\mathbf{2 0 0 3}$ & \multicolumn{1}{c|}{$\mathbf{2 0 0 4}$} & \multicolumn{1}{c|}{$\mathbf{2 0 0 5}$} & $\mathbf{2 0 0 6}$ & \multicolumn{1}{c|}{$\mathbf{2 0 0 7}$} \\
\hline Ativo Intangível & 1.318 .000 & 1.318 .000 & 1.418 .000 & 1.418 .000 & 1.418 .000 & 1.418 .000 \\
\hline Amortização acumulada & $(200.000)$ & $(269.875)$ & $(346.417)$ & $(422.958)$ & $(499.500)$ & $(576.042)$ \\
\hline Amortização Anual & & $(69.875)$ & $(76.542)$ & $(76.542)$ & $(76.542)$ & $(76.542)$ \\
\hline Ativo Intangível Líquido & 1.118 .000 & 1.048 .125 & 1.071 .583 & 995.042 & 918.500 & 841.958 \\
\hline
\end{tabular}

Observa-se que a amortização do capital durante o período contratual estaria evidenciada nas demonstrações e saber-se-ia ao certo o que deveria ser incluído nas tarifas a esse título. De posse dos demonstrativos, poder-se-ia inferir o quanto de capital já foi amortizado via receita de equilíbrio. Essa amortização de capital pelo modelo atual não é identificada pelos demonstrativos uma vez que o que está evidenciado é a depreciação de bens físicos avaliados a custo histórico.

Dessa forma, o modelo baseado na IFRIC 12 proporciona também a identificação da amortização de capital. Isso pode ser afirmado uma vez que na medida em que estão sendo cumpridas as obrigações contratuais e fixadas as receitas que conferem equilíbrio, estas estariam evidenciadas pelos demonstrativos financeiros. Por outro lado, por exemplo, se fossem fixadas tarifas que não cobrissem a amortização de capital (valor esse identificado como amortização do intangível) estaria bem caracterizada uma situação de desequilíbrio, onde novamente, haveria a intervenção do órgão regulador com a fixação de nova tarifa.

Ao proporcionar a identificação via demonstrações contábeis desses dois componentes da receita de equilíbrio (base de remuneração e amortização de capital), esse modelo também permite a simulação do fluxo de caixa que resulta em uma TIR comparável $(9,75 \%$ e 7,07\%, primeiro e segundo ciclo, respectivamente) ao WACC fixado $(11,26 \%$ e 9,95\%, primeiro e segundo ciclo, respectivamente), a comparação pode ser realizada uma vez que os valores utilizados como os parâmetros investimentos e depreciação são os mesmos utilizados pelo regulador. 
No entanto, vale ressaltar que a equação do EEF fixado nas revisões é a obrigação de que a receita tarifária cubra a Parcela A e a Parcela B, esta última entendida como os custos operacionais e a equivalência entre o ativo intangível da distribuidora remunerado pelo custo de capital e amortizado no prazo acordado.

Ponto importante a ser adicionado na equação do EEF são os direitos de indenização, que se referem aos investimentos amortizados no prazo do contrato ${ }^{93}$, os quais devem ser incluídos na equação. O raciocínio que norteia essa análise é que, antes da aprovação dos investimentos, se saberia se estes serão amortizáveis no prazo que resta do contrato. Se não houver tarifa suficiente para permitir a amortização do investimento, ele deve compor a equação do EEF com indenização do valor residual.

Contudo, pelas regras internacionais, ter-se-ia evidenciado a amortização dos direitos de exploração, possibilitando aos usuários da informação contábil a correta visualização do ativo que está sendo reduzido ou incrementado. Sendo assim, seria plausível imaginar que um possível comprador saberia quantos anos ainda tem de direito de exploração do negócio pela interpretação das demonstrações financeiras da entidade.

\subsection{PRINCIPAIS DIFERENÇAS ENCONTRADAS}

Nos tópicos acima, buscou-se apresentar a contabilização de um contrato de concessão de acordo com modelo societário atual e a contabilização desse mesmo contrato em modelo elaborado de acordo com a IFRIC 12. A observação de contabilização dos dois modelos apresentados focalizou os fatos econômicos ocorridos: início do contrato, realização de investimentos e revisões tarifárias.

Desse modo, as principais diferenças encontradas versam sobre esses fatos. A tabela a seguir, apresenta um resumo das principais diferenças.

\footnotetext{
${ }^{93}$ Além do contrato, a Lei das concessões 8.987/1995 disciplina que no advento do termo contratual (art. 36) e a encampação durante o prazo da concessão (art. 37), considerara-se passíveis de indenização apenas as "parcelas dos investimentos vinculados a bens reversíveis, ainda não amortizados ou depreciados, que tenham sido realizados com o objetivo de garantir a continuidade e atualidade do serviço concedido".

"Art. 36. A reversão no advento do termo contratual far-se-á com a indenização das parcelas dos investimentos vinculados a bens reversíveis, ainda não amortizados ou depreciados, que tenham sido realizados com o objetivo de garantir a continuidade e atualidade do serviço concedido.

Art. 37. Considera-se encampação a retomada do serviço pelo poder concedente durante o prazo da concessão, por motivo de interesse público, mediante lei autorizativa específica e após prévio pagamento da indenização, na forma do artigo anterior.
} 
Tabela 7 - Principais diferenças encontradas - modelo societário atual versus modelo IFRIC 12

\begin{tabular}{|c|c|c|}
\hline Item & Modelo Societário Atual & Modelo IFRIC 12 \\
\hline $\begin{array}{l}\text { Evidenciação do } \\
\text { ativo adquirido }\end{array}$ & $\begin{array}{l}\text { Representação por meio do grupo } \\
\text { ativo imobilizado (bens físicos). }\end{array}$ & $\begin{array}{l}\text { Representação por meio do grupo } \\
\text { ativo intangível (direitos de uso). }\end{array}$ \\
\hline Evolução do ativo & $\begin{array}{l}\text { Depreciação com base na vida útil do } \\
\text { bem. }\end{array}$ & $\begin{array}{l}\text { Amortização com base no prazo de } \\
\text { vigência do contrato. }\end{array}$ \\
\hline $\begin{array}{l}\text { Investimentos } \\
\text { realizados }\end{array}$ & $\begin{array}{l}\text { São acrescidos no grupo ativo } \\
\text { imobilizado e depreciados a taxas de } \\
\text { depreciação que consideram a vida } \\
\text { útil do bem. }\end{array}$ & $\begin{array}{l}\text { São acrescidos no grupo ativo } \\
\text { intangível e amortizados pelo período } \\
\text { de vigência do contrato. }\end{array}$ \\
\hline Identificação do EEF & $\begin{array}{l}\text { Itens analisados: } \\
\text { Formação CAPEX: } \\
\text { a) base de remuneração regulatória } \\
\text { - não é possível identificar; } \\
\text { b) amortização de capital - não é } \\
\text { possível identificar, uma vez } \\
\text { que o está representado é a } \\
\text { depreciação de bens físicos; } \\
\text { c) WACC - não pode ser } \\
\text { comparado à TIR, uma vez que } \\
\text { os valores utilizados para seu } \\
\text { cálculo não coincidem com os } \\
\text { valores fixados } \\
\text { regulatoriamente; e } \\
\text { d) ROI - Não expressa o } \\
\text { desempenho econômico uma } \\
\text { vez que os investimentos } \\
\text { utilizados na fórmula não estão } \\
\text { corretamente caracterizados. }\end{array}$ & $\begin{array}{l}\text { Itens analisados: } \\
\text { Formação CAPEX: } \\
\text { a) base de remuneração regulatória - } \\
\text { há possibilidade de identificação, } \\
\text { uma vez que o ativo intangível } \\
\text { deve ser avaliado ao valor justo } \\
\text { (fair value) e este pode coincidir } \\
\text { com o valor da base de } \\
\text { remuneração; } \\
\text { b) amortização de capital }- \\
\text { identificação por meio da } \\
\text { amortização do ativo intangível } \\
\text { adquirido no contrato; } \\
\text { c) WACC - pode ser comparado à } \\
\text { TIR, uma vez que os valores } \\
\text { utilizados para seu cálculo } \\
\text { coincidem com os valores fixados } \\
\text { regulatoriamente; e } \\
\text { d) ROI - possibilita a identificação } \\
\text { do desempenho econômico uma } \\
\text { vez que é calculado com base nos } \\
\text { investimentos (considerados } \\
\text { como ativos avaliados a fair } \\
\text { value. }\end{array}$ \\
\hline
\end{tabular}


A mais relevante diferença encontrada é, sem dúvida, a que se refere à definição de ativos sujeitos à contabilização. Deste ponto são extraídos todas as outras contribuições apresentadas: a evolução do ativo, a redução dos direitos adquiridos no contrato, a contabilização dos investimentos como aumento do direito de exploração, sua mensuração a fair value e a identificação da amortização de capital, paga via tarifa.

Cabe destacar a qualidade da discussão apresentada pela IFRIC 12 sobre a essência da transação, por meio da reflexão de que a infra-estrutura utilizada para a prestação do serviço não deve ser reconhecida como ativo imobilizado da distribuidora, haja vista que, o que se adquire por meio de contratos do tipo Service Concessions Arrangements é o direito de exploração da atividade durante um determinado período de tempo.

Com essa discussão, além de se alterar substancialmente a visão atual apresentada nos demonstrativos societários, transporta-se para as demonstrações financeiras a possibilidade de identificação de um indicador de equilíbrio. 


\section{CONSIDERAÇÕES FINAIS}

O objetivo deste trabalho foi analisar a contabilidade regulatória como instrumento de regulação econômica do setor de distribuição de energia elétrica brasileiro e demonstrar a sua potencialidade na identificação do equilíbrio econômico-financeiro dos contratos de concessão, haja vista a adoção do novo modelo contábil baseado em padrões internacionais.

Para tanto, foram feitas análises do papel da contabilidade nas funções regulatórias e uma simulação comparando o modelo societário atual com um modelo que segue os padrões internacionais de contabilidade de acordo com o proposto pela interpretação da IFRIC 12.

Da análise do papel da contabilidade regulatória, conclui-se que ela tem objetivo convergente com a contabilidade societária, no entanto, aprofunda-se na evidenciação da situação econômica e patrimonial da atividade concedida, servindo ainda como instrumento de controle e monitoramento dessa atividade. Além disso, a contabilidade regulatória é instrumento da regulação econômica, contribuindo sobremaneira na fixação e manutenção do EEF, uma vez que permite sua mensuração.

Da análise realizada por meio da simulação comparando o modelo societário atual com o modelo desenvolvido de acordo com a interpretação da IFRIC 12, conclui-se que este último difere da contabilização atualmente praticada no Brasil, em especial no que se refere ao registro dos ativos e sua mensuração.

Ao mudar a forma de reconhecimento do ativo adquirido no contrato de concessão, permitindo a adoção do fair value para mensuração do ativo adquirido no contrato, transfere para as demonstrações financeiras a possibilidade de identificação do equilíbrio econômico e financeiro da distribuidora no que se refere ao investimento a ser remunerado como valor do ativo adquirido.

Essa conclusão está embasada nas simulações realizadas, por meio dos balanços, fluxos de caixa e principalmente na comparação dos indicadores de rentabilidade, IR regulatório (Receita de Equilíbrio/Base de ativos regulatória) e ROI (Retorno sobre o Investimento). O IR regulatório é fundamentado no equilíbrio fixado no momento da revisão tarifária, enquanto o ROI fundamenta-se no investimento avaliado a fair value, tendo como base de mensuração o custo de reposição.

A perspectiva e argumentação do custo de reposição como valor justo de ativos de distribuição de energia, tem respaldo nos argumentos apresentados por Lally (2002). Neste trabalho, o autor discorre sobre a abordagem de mercado para esses ativos, argumentando que esse valor guardaria relação com as expectativas dos investidores, o que poderia levar a uma 
superavaliação e, assim, se aplicado a monopólios regulados, levaria a transferência líquida de riqueza dos consumidores correntes e futuros para os investidores. Esta argumentação leva a utilização de outra base de remuneração, no caso, o custo de reposição.

Assim, volta-se a questão-problema desta pesquisa: Qual a potencialidade de evidenciação do equilíbrio econômico e financeiro dos contratos de concessão de distribuição do setor elétrico brasileiro pelas demonstrações contábeis, haja vista a alteração do modelo contábil?

Em resposta à pergunta de pesquisa, é possível afirmar que a adoção pela contabilidade regulatória de um novo modelo com base na interpretação internacional IFRIC 12 melhora a identificação do equilíbrio econômico-financeiro previsto no contrato de concessão, representado pela receita tarifária capaz de fazer face aos custos inerentes à prestação do serviço e, ainda, remunerar e repor o capital investido no negócio.

A afirmativa acima está lastreada em dois aspectos principais:

i. na identificação da essência econômica da transação, por meio do registro do fato econômico relativo à aquisição dos direitos e sua evolução durante toda a vida do contrato, e não como no modelo societário atual, onde o que se observa é um direito sobre bens físicos concedidos pela União (poder concedente) a uma distribuidora. Como discutido anteriormente, esta não é a essência econômica da transação ocorrida, visto que a distribuidora não tem a propriedade ou o controle sobre esses bens, sendo-lhe concedido apenas o direito de usá-los para prestar o serviço público de distribuição de energia elétrica e com isso receber tarifas;

ii. na possibilidade de melhor identificação do equilíbrio econômico e financeiro, uma vez que a mensuração do ativo a fair value permite identificar a rentabilidade regulatória fixada no contrato de concessão nas demonstrações financeiras, via indicadores de retorno sobre investimentos.

Ressalta-se ainda que os componentes utilizados como parâmetros para fixação da receita de equilíbrio são retomados e fixados nas revisões tarifárias atendendo a expectativa de equilíbrio econômico-financeiro do contrato de concessão.

Além disso, a discussão apresentada sobre fair value aponta perspectivas inovadoras sobre a avaliação de ativos no Brasil, em face da edição da lei 11.638/2007, prevalecendo a essência econômica sobre a forma jurídica das transações. Sobre a mensuração do ativo adquirido a fair value, esse novo modelo trará avanços na visualização do equilíbrio 
econômico-financeiro da concessão, mesmo que essa discussão não esteja completamente sedimentada.

Outro aspecto importante é a demonstração da amortização de capital em conjugação com o declínio do ativo intangível (direito de exploração), que contribui para uma regulação econômica mais transparente e eficaz.

O processo de regulação tarifária adotada pela Aneel vem enfrentando dificuldades para concluir a fixação definitiva da receita de equilíbrio e, em alguns casos, a receita fica como provisória durante um ano. Os problemas mais sérios ocorrem em relação aos valores da Base de Remuneração de algumas empresas, isso é percebido principalmente no primeiro ciclo tarifário. Contudo, para o segundo ciclo tarifário são apresentados alguns avanços em relação a esse tema, com a aprovação das receitas de forma definitiva.

Isso decorre da dificuldade de implementação das metodologias propostas inicialmente; metodologias como o custo de reposição para avaliação de ativos são de difícil entendimento para os agentes. Além disto, o prazo para se adequar quase sempre inexiste, sendo as regras fixadas e aplicadas imediatamente, causando erros e, como no caso da Enersul, prejuízos efetivos aos consumidores. Contudo, o tempo de amadurecimento dos métodos traz reflexos no segundo ciclo tarifário.

Entende-se que metodologias para fixação da receita que confere equilíbrio, apesar de serem discutidas com agentes nas Audiências Públicas realizadas, devem ser preparadas e empregadas de forma paulatina, não acarretando prejuízos aos consumidores.

Nesse sentido, a adoção do novo modelo contábil contribuirá sobremaneira para as metodologias utilizadas, uma vez que estas poderão ser elaboradas com bases mais confiáveis de mensuração, refletindo mais adequadamente o objeto concedido.

Conclui-se ainda que este trabalho, em relação aos demais trabalhos sobre contabilidade regulatória citados, apresenta uma contribuição diferente na medida em que propõe a discussão conjunta de três categorias: contabilidade, regulação econômica e equilíbrio econômico-financeiro das concessões de distribuição de energia elétrica, a partir de uma perspectiva nova trazida pela Lei 11.638/2007 que busca a convergência para padrões internacionais de contabilidade.

A respeito do movimento de convergência iniciado pela Lei 11.638/2007, entende-se que a Aneel caminha no sentido da adoção dos padrões internacionais de contabilidade, uma vez que aprova e estabelece a obrigatoriedade para as concessionárias, autorizadas e permissionárias do serviço público de distribuição todos os pronunciamentos emitidos pelo Comitê de Pronunciamentos Contábeis - CPC. 
Como delineamento para trabalhos futuros, sugere-se analisar o que ocorre anualmente com as demonstrações financeiras e com os indicadores de rentabilidade se o ativo intangível fosse avaliado a fair value anualmente. E ainda, qual o impacto da adoção desse modelo no final dos contratos de concessão, ou seja, quando da reversão dos bens ao poder concedente, considerando esse ambiente de convergência em relação ao ambiente atual.

\subsection{LIMITAÇÕES DO TRABALHO}

As limitações do trabalho referem-se aos aspectos relacionados ao Equilíbrio Econômico-Financeiro - EEF presente no contrato de concessão. Neste trabalho foi analisado o que diz respeito aos custos com capital (CAPEX) fixados no evento da revisão tarifária periódica.

O conceito do EEF é bem mais abrangente do que foi tratado aqui, contudo, a contribuição foca na correta mensuração e reconhecimento dos custos com capital.

Devido à atualidade do tema, decorrente da publicação da Lei 11.638/2007 e à regulamentação da IFRIC 12 que entrou em vigor no início de 2008, não é possível uma análise empírica abrangente. Sendo assim, a análise baseia-se somente na interpretação analítica da IFRIC 12.

Na simulação de acordo com o modelo IFRIC 12, a cada novo investimento realizado foi considerado que este seria amortizado até o final do prazo contratual, essa consideração para investimentos realizados muito próximos ao final do contrato de concessão implicaria em amortizações muito altas, que refletiriam, consequentemente, em tarifas altas. Esse fato deve ser melhor analisado, podendo ser considerado um valor residual do contrato objeto da reversão de ativos. 


\section{REFERÊNCIAS BIBLIOGRÁFICAS}

ABRACE. Contribuição ao processo de Audiência Pública 022/2002 sobre a metodologia a ser adotada no primeiro ciclo de revisões tarifárias das distribuidoras de energia elétrica. 2002. Disponível em: <www.aneel.gov.br/audiênciapublica >.

ABRADEE. Contribuição ao processo de Audiência Pública 008/2006 sobre a metodologia a ser adotada no segundo ciclo de revisões tarifárias das distribuidoras de energia elétrica. 2006. Disponível em: <www.aneel.gov.br/audiênciapublica $>$.

ANEEL. Resoluções, Despachos, Processos, Notas Técnicas, Relatório de Voto. Disponível em: <http://www.aneel.gov.br/biblioteca/pesquisadigit.cfm>.

ANEEL. Manual de Contabilidade do Serviço Público de Energia Elétrica - MCSPEE. 2001.

AVERCH, H.; JOHNSON, L. Behavior of the firm under regulatory constraints. American Economic Review, v. 52, p. 1052-69, 1962.

BERG, S. V. Introduction to of incentive regulation. In . Public Utility Research Center. Gainesville: University of Florida, 1998.

BONBRIGHT, J. C.; DANIELSON, A. L.; KAMERSCHEN, D. R. Principles of public utility rates, 2nd ed, Arlington, Virginia, Public Utilities Reports, 1988.

BRAGANÇA, G. G. F.; CAMACHO, F. T. Avaliação de ativos regulatórios e conceitos. In: V Congresso Brasileiro de Regulação - ABAR, 2007, Recife - PE.

BRASIL. Lei no 6.404, de 15 de dezembro de 1976. Dispõe sobre as Sociedades por Ações. Diário Oficial da União, Brasília, DF, 15 dez. 1976. Seção 1, p. 24.

BRASIL. Lei n ${ }^{0}$ 8.987, de 13 de fevereiro de 1995. Dispõe sobre o regime de concessão e permissão da prestação de serviços públicos previsto no art. 175 da Constituição Federal, e dá outras providências. Diário Oficial da União, Brasília, DF, 14 fev. 1995, Seção 1, p. 1917.

BRASIL. Lei no 9.427, de 26 de dezembro de 1996. Institui a Agência Nacional de Energia Elétrica - ANEEL, disciplina o regime das concessões de Serviços Públicos de Energia Elétrica, e dá outras providências. Diário Oficial da União. Brasília, DF, 28 set. 1998, Seção 1, p. 9.

BRASIL. Lei n⿳0 10.848 , de 15 de março de 2004. Dispõe sobre a comercialização de energia elétrica, altera as Leis 5.655/1971, 8.631/1993, 9.074/1995, 9.427 /1996, 9.478/1997, 9.648/1998, 9.991/2000, 10.438/2002, e dá outras providências. Diário Oficial da União, Brasília, DF, 16 mar. 2004, Seção 1, p. 2.

BRASIL. Lei $\mathrm{n}^{\mathrm{o}}$ 11.638, de 28 de dezembro de 2007. Altera e revoga dispositivos da Lei $\mathrm{n}^{\mathrm{o}}$ 6.404, de 15 de dezembro de 1976, e da Lei no 6.385 , de 7 de dezembro de 1976, e estende às sociedades de grande porte disposições relativas à elaboração e divulgação de demonstrações financeiras. Diário Oficial da União, Brasília, DF, 28 dez. 2007. Seção 1, p. 18. 
BRASIL. Medida Provisória 449. Altera a legislação tributária federal relativa ao parcelamento ordinário de débitos tributários, concede remissão nos casos em que especifica, institui regime tributário de transição, e dá outras providências. Diário Oficial da União, Brasília, DF, 3 dez. 2008, Seção 1, p. 20.

BROADBENT, J.; GUTHRIE, J. Changes in the public sector: a review of recent alternative accounting research. Accounting, Auditing \& Accountability Journal, v. 5, n. 2, p. 3-31, 1992.

CAMACHO, F. Custo de capital de indústrias reguladas no Brasil. Revista do Banco Nacional de Desenvolvimento - BNDES, v. 11, p. 139-164, jun. 2004.

CAMACHO, F.; ROCHA, K.; BRAGANÇA, G. F. Remuneração de Capital das distribuidoras de energia elétrica: uma análise comparativa. Texto para discussão $\mathrm{n}^{\circ} 1153$ Instituto de Pesquisa Aplicada - IPEA. 2006.

CARVALHO, G. L. Sociedade de propósito específico: natureza e aplicação. 2007. UNESP.

COLLIS, J.; HUSSEY, R. Pesquisa em administração: um guia prático para alunos de graduação e pós-graduação. Trad. Lucia Simonini. 2.ed. Porto Alegre: Bookman, 2005.

COMISSÃO DE VALORES MOBILIÁRIOS - CVM. Deliberação 539. Aprova o Pronunciamento Conceitual Básico do CPC que dispõe sobre a Estrutura Conceitual para a Elaboração e Apresentação das Demonstrações Contábeis. 14 mar. 2008.

COMITÊ DE PRONUNCIAMENTOS CONTÁBEIS - CPC. A Busca da convergência da contabilidade aos Padrões Internacionais. Maio 2007. Disponível em: <www.cpc.org.br>.

Acesso em: 20/12/2008.

COMITÊ DE PRONUNCIAMENTOS CONTÁBEIS - CPC. Pronunciamento Técnico 04 Ativo Intangível. 2008. Disponível em: <www.cpc.org.br/pronunciamentos >

COMITÊ DE PRONUNCIAMENTOS CONTÁBEIS - CPC. Estrutura Conceitual para a Elaboração e Apresentação das Demonstrações Contábeis. 2008. Disponível em: $<$ www.cpc.org.br/pronunciamentos $>$.

CONSELHO FEDERAL DE CONTABILIDADE - CFC, INSTITUTO DOS AUDITORES INDEPENDENTES DO BRASIL - IBRACON. Sumário da comparação das práticas contábeis adotadas no Brasil com as Normas Internacionais de Contabilidade - IFRS. Brasília: Conselho Federal de Contabilidade. São Paulo: Ibracon, 2006.

Constituição Federativa da República do Brasil. 1988.

COOPER, S. Control, accounting and value-for-money implications of utility regulation: a literature review. Managerial Auditing Journal, v. 13, n. 2, p. 117-125, 1998.

CORREA, P.; MELO, M. A.; MUELLER B.; PEREIRA, C. Regulatory governance in Brazilian infrastructure industries. Quarterly Review of Economics and Finance, v. 48, n. 2, 2006. 
CORREIO BRASILIENZE. Brasília-DF. 05 ago. 2002. Disponível em: < www.correioweb.com.br/>.

COSTA, A. M. A. As distribuidoras de eletricidade privadas e seus controladores no Brasil: uma busca por um padrão na gestão do endividamento. 2006. 251 f. Tese (Mestrado em Energia) - Instituto de Eletrotécnica e Energia/Escola Potitécnica - Faculdade de Economia e Administração, Universidade de São Paulo, São Paulo, 2006.

DAMODARAM, A. Finanças corporativas. 2.ed. Bookman: São Paulo, 2004.

ERNEST \& YOUNG - Auditores Independentes. Estudo sobre as diferenças e similaridades entre as Normas Internacionais de Contabilidade - IFRS e as Normas e Práticas Contábeis Brasileiras - Fair Value Measurements, Brasil. 2008.

EVANS, J.; CHIN, C. E; CHIN, I. Asset valuation and rate of return considerations in public entities. Contemporary Issues in Business and Government, May 2000.

FIANI, R. Teoria da regulação econômica: estado atual e perspectivas futuras. UFRJ-IE, 2001.

GIAMBIAGI, F.; ALÉM, A. C. Finanças públicas: teoria e prática no brasil. 2.ed. Campus: Rio de Janeiro, 2001.

GORDON, M. The investment, financing, and valuation of the corporation. Irwin, Homewood, IL, 1962.

GOWLAND, D.; AIKEN, M. Accountability factors and accounting information systems of privatised companies in Australia. Intersciense Changes to Financial Management Performance Measures, Intersciense. 2005.

GUENA, R. O. (Org.) Avaliação do equilíbrio econômico-financeiros dos contratos de concessão de rodovias. 1.ed. São Paulo: FIPE/USP, 2001.

HENDRIKSEN, E. S.; BREDA, M. F. V. Teoria da contabilidade. 5.ed. São Paulo: Atlas, 1999.

IASB - Normas do International Accounting Standards Board - IASB. Disponível em: $<$ www.iasb.org $>$.

IFRIC 12 - Interpretation Service Concession Arrangements. International Accounting Standards Board - IASB, 2006.

INSTITUTO ACENDE BRASIL. Rentabilidade do Setor Elétrico Brasileiro de 1998 a 2006. Rio de Janeiro, dez. 2007. Disponível em: <www.acendebrasil.com.br>.

IUDICÍBUS, S. Teoria da contabilidade. 5.ed. São Paulo: Atlas, 1997.

IUDICÍBUS, S.; MARTINS, E.; GELBCKE E. R. Manual de Contabilidade das Sociedades por Ações. 7.ed. São Paulo: Atlas, 2007. 
JAMASB, T.; POLLITT, M. Benchmarking and regulation: international electricity experience. Utililies Policy, v. 9, p. 107-130, 2001.

Jornal Canal Energia. Edição de 2/12/2005. Disponível em: <www.canalenergia.com.br>.

LAFFONT, J.; TIROLE, J. A theory of incentives in procurement and regulation. MIT Press, Cambridge (Massachussets), 1993.

LALLY, M. Review of asset valuation methodologies: electricity lines business' system fixed assets. Discussion Paper, Commerce Commission New Zeland. 2002.

LITTLECHILD, S. Regulation of British telecommunications profitability. HMSO. 1983.

MARCHIORETTO, I. S. Contabilidade Regulatória: a introdução de práticas contábeis regulares e padronizadas como instrumento de controle e mensuração dos resultados das atividades reguladas no Estado do Mato Grosso Do Sul. Texto para discussão - Agência Estadual de Regulação dos Serviços Públicos do Estado do Mato Grosso do Sul AGEPAN, 2006.

MARTINS, E. (org.) Avaliação de empresas: da mensuração contábil à econômica. 1.ed. São Paulo: Atlas, 2006.

MARTINS, V. A. Interações entre a estrutura de Capital, valor da empresa e o valor dos ativos. 2006. 155 f. Tese (Doutorado) - Departamento de Contabilidade da Universidade de São Paulo - Programa de Pós-Graduação em Ciências Contábeis - Faculdade de Economia, Administração e Contabilidade, Universidade de São Paulo, São Paulo, 2006.

MARTINS, E.; MARTINS, V. A.; MARTINS, E. A. Normatização contábil: ensaio sobre a sua evolução e o papel do CPC. Revista de Informação Contábil - RIC. Universidade Federal de Pernambuco, v. 1, n. 1, p. 7-30, set. 2007.

MARTINS, V. M.; ANDRADE, M. E. C. Análise dos normativos de contabilidade internacional sobre contabilização de contratos de parcerias público-privada. Encontro de Administração Pública e Governança, ANPAD, Salvador - BA, 2008.

MATARAZZO, D. C. Análise financeira de balanços: abordagem básica e gerencial. 6.ed. São Paulo: Atlas, 1998.

PEDELL, B. Regulatory risk and the cost of capital: determinants and implications for rate regulation. 1.ed. Springer 2006.

PIRES, J. C. L. Mecanismos de regulação tarifária do setor elétrico. Texto para discussão no 64, Banco Nacional de Desenvolvimento Econômico e Social-BNDES, Rio de Janeiro, jul. 1998.

PIRES, J. C. L. ; GOLDSTEIN. A. Agências reguladoras brasileiras: avaliação e desafios. Revista do Banco Nacional de Desenvolvimento Econômico e Social - BNDES, ES (16), p. 3-42, Rio de Janeiro, 2001.

PIRES, J. C. L.; OLIVEIRA, G. R. Problemas regulatórios nas indústrias de infra-estrutura no atual contexto brasileiro. Anais do I Congresso Brasileiro de Regulação. Salvador-BA, 2000. 
REHBEIN A. R.; ENGELMANN, D.; GONÇALVES, O. Índices-padrão: uma ferramenta para contabilidade regulatória. $18^{\circ}$ Congresso Brasileiro de Contabilidade, Gramado-RS, 2008 .

REHBEIN A. R.; GONÇALVES, O. As contribuições da contabilidade regulatória na padronização dos procedimentos contábeis adotados pelos prestadores de serviços de saneamento. Capítulo 12. Normatização da Prestação de serviços de água e esgoto. 1.ed. Fortaleza: Pouchaim Ramos, 2008.

ROSS, S. A. The arbitrage theory of capital asset pricing. Journal of Economic Theory, Dec. 1976.

ROSS, S. A.; WESTERFIELD, R. W.; JAFFE, F. J. Administração Financeira. 2.ed. São Paulo: Atlas, 2002.

PELTZMAN, S. Toward a more general theory of regulation. Journal of Law and Economics, v. 19, p. 211-240, Aug. 1976.

SANVICENTE, A. Z.; MINARDI, A. M. A. F. Problemas de Estimação do Custo de Capital no Brasil. Finance Lab Working Paper, n. 9, 1999. Disponível em: <www.ibmec.br>.

SANVICENTE, A. Z.; MINARDI, A. M. A. F. Estimação do custo médio de capital de empresas sob processo de regulação econômica no Brasil. Faculdades Ibmec, 2004. Disponível em: <www.ibmec.br>.

SCHMIDT, M.; BLOWING, W. Regulation and accounting standards enforcement in Germany and Europe: an economic perspective. International Review of Law and Economics, v. 25, p. 164-5, 2005.

SCHMIDT, P.; SANTOS, J. L. Avaliação de ativos intangíveis. São Paulo: Atlas, 2002.

SHARPE, W. F. Capital assets prices: a theory of market equilibrium under conditions of risk. Journal of Finance, Columbus, v. 19, n. 3, p. 425-442, Sept. 1964.

STIGLER, G. J. The theory of economic regulation. Bell Journal Economics and Management Science, n. 2, p. 3-21, Spring 1971.

STIGLITZ, J. E. Information and economic analysis: a perspective. Economic Journal, v. 95 (o), Supl., p. 21-41, 1985.

TOZZINI, S. Conseqüências da regulação econômica sobre as estratégias empresariais das distribuidoras de distribuição de energia elétrica - Brasil. 2006. 263 f. Tese (Doutorado Programa Interunidades de Pós-Graduação em Energia) - EP/FEA/IEE/IF da Universidade de São Paulo, São Paulo, 2006.

VALOR ECONÔMICO. 02. mar. 2005. Disponível em: <www.valoronline.com.br>. 


\section{ANEXO I}

Trecho do Contrato de Concessão da Eletropaulo n⿳ํ.. 162/1998, assinado entre a Agência Nacional de Energia Elétrica e a Eletropaulo Metropolitana Eletricidade de São Paulo S.A.

\section{CLÁUSULA SÉTIMA - TARIFAS APLICÁVEIS NA PRESTAÇÃO DOS SERVIÇOS}

Pela prestação dos serviços que lhe são concedidos por este Contrato, a DISTRIBUIDORA cobrará as tarifas discriminadas no Anexo II, que é rubricado pelas partes e integra este instrumento, homologadas pelo PODER CONCEDENTE.

Primeira Subcláusula - É facultado à DISTRIBUIDORA cobrar tarifas inferiores às discriminadas no Anexo II, desde que não implique em pleitos compensatórios posteriores quanto à recuperação do equilíbrio econômico-financeiro e resguardadas as condições constantes na Sexta Subcláusula da Cláusula Segunda.

Segunda Subcláusula - A DISTRIBUIDORA reconhece que as tarifas indicadas no Anexo II em conjunto com as regras de reajuste e revisão descritas nesta Cláusula, são suficientes, nesta data, para a adequada prestação dos serviços concedidos e a manutenção do equilíbrio econômico-financeiro deste Contrato.

Terceira Subcláusula - Os valores das tarifas de que trata esta Cláusula serão reajustados com periodicidade anual, um ano após a "Data de Referência Anterior", sendo esta definida da seguinte forma:

I - no primeiro reajuste, a data de assinatura deste Contrato; e

II - nos reajustes subseqüentes, a data de início da vigência do último reajuste ou da revisão que o tenha substituído, de acordo com o disposto nesta Cláusula.

Quarta Subcláusula - A periodicidade de reajuste de que trata a subcláusula anterior poderá ocorrer em prazo inferior a um ano, caso a legislação venha assim a permitir, adequando-se a "Data de Referência Anterior" à nova periodicidade estipulada.

Quinta Subcláusula - Para fins de reajuste tarifário, a receita da DISTRIBUIDORA será dividida em duas parcelas:

Parcela A: parcela da receita correspondente aos seguintes custos: cota da Reserva Global de Reversão - RGR; cotas da Conta de Consumo de Combustíveis - CCC; encargos da compensação financeira pela exploração de recursos hídricos para fins de geração de energia elétrica; valores relativos à fiscalização dos serviços concedidos; compra de energia; e encargos de acesso aos sistemas de transmissão e distribuição de energia elétrica para revenda. 
Parcela B: valor remanescente da receita da DISTRIBUIDORA, excluído o ICMS, após a dedução da Parcela A.

Sexta Subcláusula - O reajuste será calculado mediante a aplicação, sobre as tarifas homologadas, na "Data de Referência Anterior" do Índice de Reajuste Tarifário (IRT), assim definido:

$I R T=\frac{V P A_{1}+V P B_{0} \times(I V I \pm X)}{R A_{0}}$

Onde:

$\mathrm{VPA}_{1}$ - Valor da Parcela A referido na Subcláusula anterior, considerando-se as condições vigentes na data do reajuste em processamento e a energia comprada em função do "Mercado de Referência", aqui entendido como mercado de energia garantida da DISTRIBUIDORA, nos doze meses anteriores ao reajuste em processamento;

$\mathrm{RA}_{0}$ - Receita Anual, calculada considerando-se as tarifas homologadas na "Data de Referência Anterior" e o "Mercado de Referência", não incluindo o ICMS;

$\mathrm{VPB}_{0}$ - Valor da Parcela B, referida na Subcláusula anterior, considerando-se as condições vigentes na "Data de Referência Anterior", e o "Mercado de Referência", calculado da seguinte forma:

$\mathrm{VPB}_{0}=\mathrm{RA}_{0}-\mathrm{VPA}_{0}$

onde:

$\mathrm{VPA}_{0}$ - Valor da Parcela A referida na Subcláusula anterior, considerando-se as condições vigentes na "Data de Referência Anterior" e a energia comprada em função do "Mercado de Referência";

IVI - Número índice obtido pela divisão dos índices do IGPM da Fundação Getúlio Vargas, ou do índice que vier a sucedê-lo, do mês anterior à data do reajuste em processamento e o do mês anterior à "Data de Referência Anterior". Na hipótese de não haver um índice sucedâneo, o PODER CONCEDENTE estabelecerá novo índice a ser adotado; e

X - Número índice definido pela ANEEL, de acordo com a Oitava Subcláusula desta Cláusula, a ser subtraído ou acrescido ao IVI.

Sétima Subcláusula - A ANEEL, de acordo com o cronograma apresentado nesta subcláusula, procederá às revisões dos valores das tarifas de comercialização de energia, alterando-os para mais ou para menos, considerando as alterações na estrutura de custos e de mercado da DISTRIBUIDORA, os níveis de tarifas observados em empresas similares no contexto nacional e internacional, os estímulos à eficiência e à modicidade das tarifas. Estas revisões obedecerão ao seguinte cronograma: a primeira revisão será procedida um ano após o 
quarto reajuste anual concedido, conforme previsto na Terceira Subcláusula; a partir desta primeira revisão, as subseqüentes serão realizadas a cada 4 (quatro) anos.

Oitava Subcláusula - No processo de revisão das tarifas, estabelecido na subcláusula anterior, a ANEEL estabelecerá os valores de X, que deverá ser subtraído ou acrescido do IVI ou seu substituto, nos reajustes anuais subseqüentes, conforme descrito na Subcláusula Sexta desta cláusula. Para os primeiros 4 (quatro) reajustes anuais, o valor de $\mathrm{X}$ será zero.

Nona Subcláusula - Sem prejuízo dos reajustes e revisões a que se referem as subcláusulas anteriores desta Cláusula, caso hajam alterações significativas nos custos da DISTRIBUIDORA, incluindo as modificações de tarifas de compra de energia elétrica e encargos de acesso aos sistemas de transmissão e distribuição de energia elétrica que possam ser aprovadas pela ANEEL durante o período, por solicitação desta, devidamente comprovada, a ANEEL poderá, a qualquer tempo, proceder à revisão das tarifas, visando manter o equilíbrio econômico-financeiro deste Contrato.

Décima Subcláusula - No atendimento do disposto no $\S 3^{\circ}$ do art. $9^{\circ}$ da Lei no 8.987/95, ressalvados os impostos sobre a renda, a criação, a alteração ou a extinção de quaisquer tributos ou encargos legais, após a assinatura deste Contrato, quando comprovado seu impacto, implicará a revisão das tarifas, para mais ou para menos, conforme o caso.

Décima Primeira Subcláusula - Na hipótese de ter ocorrido, após a "Data de Referência Anterior", revisões de tarifas previstas na subcláusula anterior, que tenham sido realizadas por alteração de impostos ou encargos que não aqueles constantes da Parcela A, quando do reajuste previsto na Sexta Subcláusula desta cláusula, as tarifas, após a aplicação do IRT, serão alteradas, para mais ou para menos, pelos mesmos percentuais destas revisões.

Décima Segunda Subcláusula - A DISTRIBUIDORA, na eventualidade de qualquer de seus consumidores se tornar autoprodutor, ou vir a ser atendido por outra DISTRIBUIDORA ou produtor independente, poderá cobrar, pela utilização de suas instalações, as tarifas específicas estabelecidas pela ANEEL, que serão fixadas de forma a assegurar equivalência aos valores das parcelas de suas tarifas de fornecimento, correspondentes às instalações envolvidas no transporte de energia.

Décima Terceira Subcláusula - Nos contratos de acesso ao sistema de transmissão e distribuição que celebrar com outras distribuidoras, a DISTRIBUIDORA cobrará as tarifas específicas, homologadas pela ANEEL.

Décima Quarta Subcláusula - É vedado à DISTRIBUIDORA cobrar dos consumidores de energia elétrica, sob qualquer pretexto, valores superiores àqueles homologados pela ANEEL, observado o disposto na Sexta Subcláusula da Cláusula Segunda deste Contrato. 
Décima Quinta Subcláusula - A DISTRIBUIDORA obriga-se a obter a energia elétrica requerida pelos usuários ao menor custo efetivo, dentre as alternativas disponíveis, quando comparado com os custos observados no contexto nacional e internacional.

Décima Sexta Subcláusula - Havendo alteração unilateral do Contrato que afete o seu inicial equilíbrio econômico-financeiro, a ANEEL deverá restabelecê-lo, a partir da data da alteração mediante comprovação da DISTRIBUIDORA. 